РИСОВОДСТВО

НАУЧНО-ПРОИЗВОДСТВЕННЫЙ ЖУРНАЛ

\section{ISSN 1684 - 2464}

Учредитель: Федеральное государственное

бюджетное научное учреждение «Федеральный научный центр риса»

Издается с 2002 года

Периодичность - 4 выпуска в год

Журнал включен в Перечень ведущих рецензируемых научных журналов и изданий, в которых должны быть опубликованы основные научные результаты диссертаций на соискание ученой степени доктора наук, на соискание ученой степени кандидата наук. Дата включения издания

в перечень - 6 июня 2017 года.

Главный редактор

C. В. ГАРКУША (ФНЦ риса),

д-р с.-х. наук, профессор

Заместитель главного редактора

B. C. КОВАЛЕВ (ФНЦ риса)

д-р с.-х. наук, профессор

Научный редактор

Н. Г. ТУМАНЬЯН (ФНЦ риса)

д-р биол. наук, профессор

Редакционная коллегия

И. Б. АБЛОВА (НЦЗ им. П. П. Лукьяненко), д-р с.-х. наук

Т. Ф. БОЧКО (КубГУ). канд. биол. наук

ДЖАО НЬЯНЛИ (Китай, Ляонинская Академия с.-х. наук), канд. наук

B. A. ДЗЮБА (ФНЦ риса), д-р биол. наук, профессор

Л. В. ЕСАУЛОВА (ФНЦ риса), канд. биол. наук

Г. Л. ЗЕЛЕНСКИИ (ФНЦ риса), д-р с.-х. наук, профессор

С. В. КИЗИНЁК (РПЗ «Красноармейский»

им. А. И. Майстренко), д-р с.-х. наук

C. В. КОРОЛЕВА (ФНЦ риса), канд. с.-х. наук

П. И. КОСТЫЛЕВ (ФГБНУ «Аграрный научный центр

«Донской»), д-р с.-х. наук, профессор

В. А. ЛАДАТКО (ФНЦ риса), канд. с.-х. наук

Ж. М. МУХИНА (ФНЦ риса), д-р биол. наук

А. Н. ПОДОЛЬСКИХ (Казахский НИИ рисоводства им. И. Жахаева), д-р с.-х. наук

М. А. СКАХЕННИК (ФНЦ риса), д-р биол. наук

А.И. СУПРУНОВ (НЦЗ им. П. П. Лукьяненко),

д-р с.-х. наук

E. M. ХАРИТОНОВ (ФНЦ риса), академик РАН, профессор

М. И. ЧЕБОТАРЕВ (КубГАУ), д-р техн. наук, профессор

\section{А. Х. ШЕУДЖЕН (ФНЦ риса), академик РАН, профессор}

\section{Переводчики. И.С. ПАНКОВА (ФНЦ риса)}

\section{Корректор: С.С. ЧИХИКОВА}

Адрес редакции:

350921, Россия Краснодар, Белозерный, 3 ,

arrri_kub@mail.ru, «В редакцию журнала».

Научный редактор: тел.: (861) 229 - 41 - 49

Свидетельство о регистрации СМИ

№ 019255 от 29.09.1999,

выдано Государственным комитетом РФ по печати.

В журнале публикуются оригинальные статьи проблемного и научно-практического характера, представляющие собой результаты исследований по физиологии, биотехнологии, биохимии, агрохимии; методические рекомендации по использованию сортов в различных почвенно-климатических регионах; сообщения о селекционных и семеноводческих достижениях; рассмотрение производственных и экономических проблем отрасли; а также обзорные, систематизирующие, переводные статьи, рецензии.
RICE GROWING

\section{SCIENTIFIC RESEARCH AND PRODUCTION MAGAZINE}

Founder: Federal State Budgetary Scientific Institution ' Federal Scientific Rice Centre

Published since 2002

Periodicity 4 issues a year

Journal is included into List of Leading peer-reviewed ournals and publications, where basic scientific results of doctoral dissertations and Ph.D. dissertations should be published. Date of issue inclusion into the list - June 6th 2017.

Editor-in-Chief

S. V. GARKUSHA (FSC of rice)

Dr. Sc. \{Agriculture\}, professor

Deputy Chief Editor

V. S. KOVALYOV (FSC of rice)

Doctor of Agricultural Sciences, professor

Scientific Editor

N. G. TUMANYAN (FSC of rice)

Doctor of Biological Sciences, professor

Editorial Board

I. B. ABLOVA (Krasnodar Research Institute of Agriculture named after P. P. Lukianenko), Dr. of agricultural sciences

T. F. BOCHKO (KubSU), Ph.D. in biological sciences

ZHAO NIANLI (China, Liaonong Academy of Agricultural Science), Ph. D

V. A. DZUBA (FSC of rice), Dr. of biological sciences, professor

L. V. ESAULOVA (FSC of rice), Ph.D. in biological sciences

G. L. ZELENSKY (KubSAU), Dr. of agricultural sciences, professor

S. V. KIZINEK (Krasnoarmeysky Rice Growing Pedigree Plant

named after A. I. Maystrenko), Dr. of agricultural sciences

S. V. KOROLYOVA (FSC of rice). Ph.D. in agricultural sciences P. I. KOSTYLEV (SSE «ARC «Donskoy»), Dr. of agricultural sciences, professor

V. A. LADATKO (FSC of rice). Ph.D. in agricultural sciences

Zh. M. MUKHINA (FSC of rice), Dr. of biological sciences

A. N. PODOLSKIKH (Kazakh Scientific Research Institute of Rice Growing named after I. Zhakhaev), Dr. of agricultural sciences

M. A. SKAZHENNIK (FSC of rice), Dr. of biological sciences

A. I. SUPRUNOV (Krasnodar Research Institute of Agriculture named after P. P. Lukianenko), Dr. of agricultural sciences

E. M. KHARITONOV (FSC of rice), Academician of Russian Academy of Sciences, professor

M. I. CHEBOTAREV (KubSAU), Dr. of engeneering sciences, professor

A. KH. SHEUDZHEN (FSC of rice), Academician of Russian

Academy of Sciences, professor

Interpreter I. S. PANKOVA (FSC of rice)

Proofreader: S.S. CHIZHIKOVA

Address:

3, Belozerny, Krasnodar, 350921, Russia

arri_kub@mail.ru, «Attn. Editors of the Magazine» Scientific

Editor: tel. (861) $229-41-49$

Mass Media Registration Certificate

№ 019255 dd. 29.09.1999, issued by National Press Committee of the Russian Federation.

The magazine features original articles addressing problem areas and applied scientific research results (namely, those related to physiology, biotechnology, biochemistry and agrochemistry); methodological recommendations on the use of rice varieties in various soil and climatic regions; reports on breeding and seed growing achievements; reviews of production and financial issues faced by the industry; overviews, systematizations, translations and reviews of articles. 


\section{СОДЕРЖАНИЕ}

\section{НАУЧНЫЕ ПУБЛИКАЦИИ}

\section{Зеленский Г.Л., Зеленская О.В., Кобинякова К.Ю.}

Изменчивость количественных признаков длиннозерных сортов риса в зависимости от условий среды

Гончарова Ю.К., Харитонов Е.М., Свинарев С.В.

Полиморфизм локусов, определяющих признак «пустозерность» у отечественных сортов риса при высоких температурах воздуха

Гученко С.C.

Результаты селекционной оценки перспективных дигаплоидных линий риса, полученных в культуре пыльников in vitro

Костылев П.И., Аксенов А.В., Краснова Е.В., Дубина Е.В.

Сравнительная оценка урожайности суходольных образцов риса при разных режимах орошения

Шеуджен А. Х., Бондарева Т.Н., Петрик Я.Б.

Потребление и вынос биогенных элементов растениями риса при посеве обогащенными цинком семенами

Мухаммед Умер Фарук, Цзяньцин Чжу

Особенности накопления кадмия и селена растениями риса при разных сроках посадки (посева)

Волкова Г.В., Гладкова Е.В., Ким Ю.С., Данилова А.В., Надыкта В.Д.

Эффективность протравителей виталон, кс и клад, кс на озимой пшенице против семенной и почвенной инфекции

Козлова И.В.

Оценка исходного материала в селекционном процессе жаростойких сортов томата для Юга России

Лазько В.Э., Якимова О.В.

Применение вторичной целлюлозы в качестве мульчирующего материала на летних посевах дыни сорта Стрельчанка

Якимова О.В., Лазько В.Э., Благородова Е.Н.

Экономическая эффективность производства товарного чеснока на примере одного из хозяйств Краснодарского края

Гончарова Ю.К., Харитонов Е.М., Очкас Н.А., Гончаров С.В., Свинарев С.В. Методы анализа и механизмы устойчивости к засухе (обзор)

\section{Садиков А.Т.}

Получение эколого-геогрфически отдаленных внутривидовых гибридов хлопчатника и наследование его хозяйственно-ценных признаков 


\section{TABLE OF CONTENTS}

\section{SCIENTIFIC PUBLICATIONS}

\section{G.L. Zelensky, O.V. Zelenskaya, K.Y. Kobinyakova}

Variability of quantitative traits of long-gran rice varieties depending on environmental conditions

\section{J.K. Goncharova, E.M. Kharitonov, S.V. Svinaryev}

Polymorphism locus determining trait "empty grain" in domestic rice varieties at high air tem-

peratures

\section{S.S. Guchenko}

The results of the selection dihaploids evaluation of promising lines of rice obtained in the anther culture in vitro

П.И. Костылев, А.В. Аксенов, Е.В. Краснова, Е.В. Дубина

Comparative assessment of upland rice varieties under different irrigation regimes

\section{A.K. Sheudzen, T.N. Bondareva, Y.B. Petric}

Consumption and removal of nutrients by rice plants when sowing zinc-rich seeds

\section{M.U. Farooq, Jianqing Zhu}

The paradox in accumulation behavior of cadmium and selenium at different planting times in rice 39

\section{G.V. Volkova, E.V. Gladkova, Y.S. Kim, A.V. Danilova, V.D. Nadykta}

Effectiveness of vitalon, cs and clad, cs protectants on winter wheat against seed and soil infection

I.V. Kozlova

Evaluation of starting material when breeding heat resistant tomato varieties for the South of Russia

V.E. Lazko, O.V. Yakimova

The use of recycled cellulose as a mulching material in summer crops of Strelchanka melon

\section{V.E. Lazko, O.V. Yakimova, E.N. Blagorodova}

Economic efficiency of commercial garlic production on the example of one of the farms in the Krasnodar territory

J.K. Goncharova, E.M. Kharitonov, N.A. Ochkas, S.V. Goncharov, S.V. Svinaryev Analysis methods and mechanisms of resistance drought

\section{A.T. Sadikov}

Received ecologo-geographically remote intraspecific hybrids of cotton and their inheritance of economically valuable parameters 


\section{«РИСОВОД БОЖЬЕЙ МИЛОСТЬЮ» (к 90-летию со дня рождения В.А. Попова)}

Продолжение. Начало на 2 стр. обложки

Основное направление научной деятельности отдела, который возглавлял Вячеслав Алексеевич, система управления водными ресурсами рисовых водохозяйственных комплексов, конструкции рисовых систем и их экологически обоснованные параметры орошения и дренажа, мелиоративные условия и режим орошения для формирования запланированных урожаев, автоматизация поливов, методы орошения в острозасушливые моловодные годы (импульсное затопление, капельное орошение, меж- и внутрисистемный водооборот и др.), принцип «точного» (прецизионного) водопользования в период первоначального затопления, формирования урожая и предуборочного осушения чека и влияние их режима на рост, развитие и продуктивность риса.

В 1971 г. В. А. Попов защитил кандидатскую диссертацию по теме: «Разработка и исследования маячнополосового способа кулисной планировки в условиях сложных рельефов рисовых массивов», а в 1987 г. в Московском гидромелиоративном институте - диссертацию на соискание ученой степени доктора технических наук по теме: «Методы совершенствования рисовых оросительных систем». В 1988 г. ему присвоено ученое звание «профессор».

Научная деятельность профессора В.А. Попова связана с разработкой математических моделей водопотребления и высокоэффективных мелиоративных агротехнологий и методов управления мелиоративным состоянием почв рисовых оросительных систем. Им впервые разработана теория движения грунтовых вод под плоской поверхностью их уровня. На её основе разработан способ формирования под чеком пресной водяной подушки из речной воды, которая исключала как ирригационное, так и вторичное засоление почв, что имело огромное практическое значение, так как массивы рисовых систем в бывшем СССР, как правило, размещены в приморских низменностях с близким залеганием сильноминерализованных грунтовых вод (Приазовская, Прикаспийская, Приаральская). На основе теории движения грунтовых вод автором решены проблемы террасности чеков, аэрации почвенно-грунтовых вод, разработана техника первоначального затопления рисовых чеков и их предуборочного осушения.

В научной среде профессор В.А. Попов известен также как ученый, разработавший эколого-биологические основы инженерных мелиораций почв. В частности в журнале «Вестник РАСХН» опубликован цикл его статей, раскрывающих диалектическое единство инженерной мелиорации и экологии риса: «Экологобиологические аспекты программирования урожаев» (2003), «Эколого- и селекционно-технологический подход к созданию суперурожайного риса» (2007), «Физика и энергетика поглотительных свойств корней риса» (2005). В этих публикациях содержатся формулы трёх открытий в области физики и энергетики экосистемы «Растения - окружающая среда».

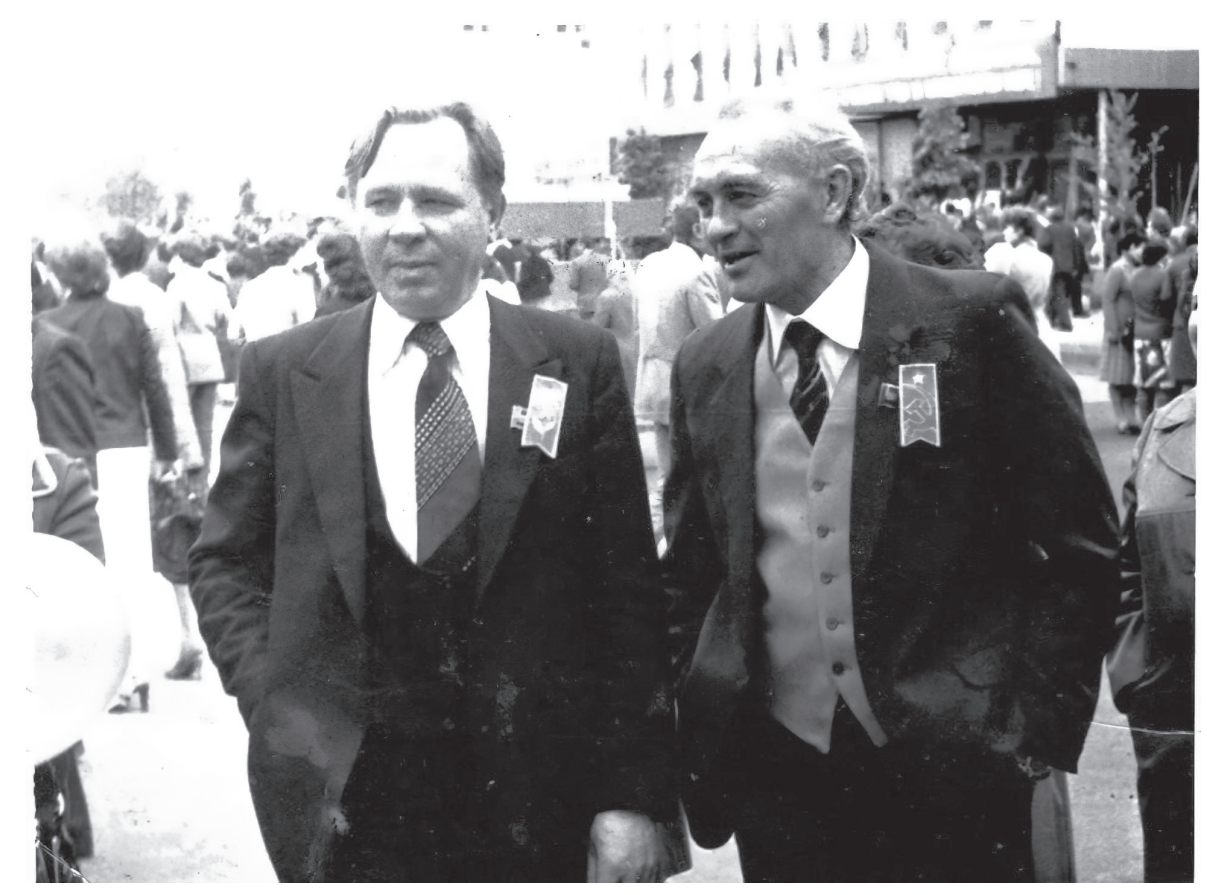

В.А. Попов и Е.П. Алешин 
По образному выражению академика Е.П. Алешина, В.А. Попов - «рисовод божьей милостью». Он человек высочайшей культуры, такта, богатого природного дарования и большой доброты. Выделяется эрудицией, интеллектом, умением слушать и слышать собеседника, цельностью общей и профессиональной этики. Его украшают скромность в общении и большая притягательная душевная сила, сдержанность и рассудительность. Никогда не допускает резких выпадов, замечания делает в очень деликатной форме. Я неоднократно консультировался у него по вопросам мелиорации и никогда не получал отказа. Благодарен судьбе за предоставленную возможность работать с ним и пользоваться его научным багажом.

Профессором В.А. Поповым опубликовано более 150 научных работ, подготовленных лично или в соавторстве, в том числе монографии: «Планировка рисовых полей» (Москва, 1971), «Регулирование грунтовых вод на рисовых системах» (Краснодар, 1984), «Агротехника риса на засоленных землях» (Ростов-на-Дону, 1986); «Совершенствование рисовых систем Кубани» (Краснодар, 1988), «Научные основы семеноводства риса» (Краснодар, 1996); «Эколого-мелиоративное состояние почв рисовой оросительной системы Адыгеи и приемы его улучшения» (Майкоп, 1999); «Система орошения риса» (2000); “Система рисоводства Краснодарского края» (Краснодар, 2005); «Методика полевых мелиоративных опытов в рисоводстве» (Краснодар, 2012); «Агроклиматология и гидравлика рисовых экосистем» (Краснодар, 2013). Он автор более 20 изобретений. Под его научным руководством защищено более 15 кандидатских диссертаций; был официальным оппонентом многих кандидатских и докторских диссертаций.

Наряду с обширной и плодотворной научно-исследовательской деятельностью, профессор В.А. Попов принимал активное участие в общественной жизни. В разные годы был секретарем партийного комитета КПСС Всесоюзного НИИ риса, председателем профсоюзного комитета, членом методической комиссии, ученых и диссертационных советов, редколлегий журналов; являлся постоянным представителем Всесоюзного НИИ риса на Кубе, в Венгрии и Болгарии.

Профессор В.А. Попов награжден многочисленными медалями, дипломами и почетными грамотами. $\mathrm{K}$ этим наградам необходимо добавить уважение и благодарность коллег и учеников. Трудами таких ученых, как Вячеслав Алексеевич Попов, создавалась слава Кубани и ими гордится земля кубанская.

\section{ПЕРСОНАЛИЯ:}

1. Шеуджен А.Х., Галкин Г.А. Ученые-рисоводы Кубани. Краснодар, 1998. - 80 с.; с. 44.

2. Шеуджен А.Х. Харитонов Е.М., Бондарева Т.Н. На службе земли кубанской. - Майкоп: РИПО «Адыгея», $1999 .-$ 552 c.; c. 373-374.

3. Флагман рисоводства России / А.Х. Шеуджен, Е.М. Харитонов, Т.Н. Бондарева, Г.А. Галкин, В.Ф. Руденко, Г.Г. Фанян, Х.Д. Хурум. - Майкоп: «Полиграфиздат «Адыгея», 2006. - 380 с.; с. 149.

4. Всероссийский научно-исследовательский институт риса: история и современность / Е.М. Харитонов, А.Х. Шеуджен, Т.Н. Бондарева, Г.А. Галкин, С.В. Кизинек, Г.Г. Фанян. - Мацкоп: «Полиграф ЮГ», 2011. - 300 с.; с.1 $64-165$.

А.Х. Шеуджен, академик РАН 
DOI: DOI 10.33775/1684-2464-2020-49-4-6-10

УДК 633.18:631.52
Г.Л. Зеленский, д-р с.-х. наук, О.В. Зеленская, канд. биол. наук, К.Ю. Кобинякова, магистрант г. Краснодар, Россия

\section{ИЗМЕНЧИВОСТЬ КОЛИЧЕСТВЕННЫХ ПРИЗНАКОВ ДЛИННОЗЕРНЫХ СОРТОВ РИСА В ЗАВИСИМОСТИ ОТ УСЛОВИЙ СРЕДЫ}

При изучении длиннозерных сортов риса Снежинка и Злата в конкурсном испытании установлено, что краевой эффект делянок оказывает существенное влияние на рост и развитие растений. Отбором растений для биометрического анализа из первого, второго и третьего ряда делянок была создана популяция, гетерогенная по морфологическим признакам. Проведенный статистический анализ этих растений показал, что у обоих сортов признаки распределились на мало, средне и сильно изменчивые. У мало изменчивых признаков коэффициент вариации (CV) составлял 4 - 7 \%. К этим признакам относятся отношение длины зерновки к ширине (I/b), длина метелки и высота растений. К средне изменчивым признакам (CV = $11-19 \%)$ можно отнести плотность метелки, количество зерен в метелке и массу зерна с главной метелки. Сильно изменчивыми признаками (CV = 20 - 28 \%) являются общее число колосков в метелке, продуктивная кустистость, стерильность колосков в метелке и масса зерна с растения.

По результатам биометрического анализа растений сортов Снежинка и Злата выделены «лучшие» и «худшие» по массе зерна с главной метелки. Выращенное в селекционном питомнике потомство этих растений сформировало метелки, близкие по массе зерна. Этот факт подтверждает, что различия между «худшими» и «лучшими» растениями имеют модификационную природу.

Ключевые слова: рис, длиннозерный сорт, количественные признаки, модификационная изменчивость.

\section{VARIABILITY OF QUANTITATIVE TRAITS OF LONG-GRAN RICE VARIETIES DEPENDING ON ENVIRONMENTAL CONDITIONS}

When studying long-grain rice varieties Snezhinka and Zlata in a competitive trial, it was found that the edge effect of plots has a significant impact on the growth and development of plants. By selecting plants for biometric analysis from the first, second, and third rows of plots, a population was developed that was heterogeneous in terms of morphological traits. The statistical analysis of these plants showed that in both varieties the traits were distributed into little, medium and highly variable. The coefficient of variation (CV) for slightly variable traits was 4-7\%. These traits include the ratio of the grain length to the width (I / b), panicle length, and plant height. The medium variable traits (CV =11-19\%) include the panicle density, the number of grains in the panicle, and the mass of grain from the main panicle. The highly variable traits (CV =20-28 \%) are the total number of spikelets in a panicle, productive tillering, sterility of spikelets in a panicle, and grain weight per plant.

According to the results of biometric analysis of plants of varieties Snezhinka and Zlata, the "best" and "worst" plants in terms of grain weight from the main panicle were identified. The offspring of these plants grown in the breeding nursery formed panicles similar in grain weight. This fact confirms that the differences between the "worst" and "best" plants are of a modification nature.

Keywords: rice, long-grain variety, quantitative traits, modification variability.

\section{Введение}

На влияние условий среды растения, как и другие организмы, реагируют определенными действиями и/или изменением состояния. Эти изменения могут быть как модификационными (ненаследственными), так и генетическими. Наиболее доступны для наблюдения и измерения морфологические адаптивные изменения на организменном уровне: изменение высоты растений, формы роста, соотношения величин вегетативных и генеративных органов и т.д. Конечный результат влияния среды на растения, как правило, определяется биологическими особенностями самого растения. Изучение модификационной изменчивости хозяйственно-ценных признаков позволя- ет разработать агроэкологический паспорт сорта. Так, на примере элементов продуктивности колоса озимой пшеницы И. Н. Кудряшовым и сотрудниками (2019) была изучена фенотипическая и экологическая вариабельность и выделены признаки с низкой, средней и высокой степенью модификационной изменчивости [3].

Растения в процессе своей жизнедеятельности не только подвержены влиянию различных абиотических и биотических факторов среды, но и сами оказывают обратное влияние на компоненты окружающей среды [9]. Культурные растения в составе агрофитоценоза выполняют роль доминанта-эдификатора. По эдификаторности, т.е. способности влиять на 
среду, согласно классификации В. В. Туганаева, рис наряду с яровыми зерновыми культурами относится к группе среднеэдификаторных растений сплошного весеннего посева, достаточно высокорослым, с проективным покрытием 70-80 \%, большей частью быстро развивающимся после появления всходов [5]. Унификация популяций культурных растений, в том числе и риса, в пределах сорта связана с деятельностью земледельца: посев семян в один срок, на одинаковую глубину на специально спланированную поверхность поля, залив определенным слоем воды и т.д. [6, 8]. Тем не менее, в процессе роста и развития растений риса отмечается варьирование различных количественных признаков, отражающихся при проведении биометрической оценки. Это может быть связано с разнокачественностью семян, степенью благоприятности регенерационной ниши, зависящей от микровариаций почвы, конкурентными взаимоотношениями, разницей в темпах роста растений. На количественные признаки растений риса также значительное влияние могут оказывать погодно-климатические условия сезона выращивания, причем сезонные адаптации пока изучены недостаточно, особенно в экстремальных условиях среды $[4,7,10]$.

\section{Цель исследований}

Изучить изменчивость морфологических признаков растений риса в зависимости условий, создающихся в разных рядках делянок конкурсного испытания.

\section{Материал и методы}

Полевые опыты проводили в 2018-2019 гг. на ЭОУ ФНЦ риса. Подготовку почвы, уход за растениями осуществляли с учетом рекомендаций по возделыванию риса, принятых для зоны. Водный режим выдерживали согласно варианту укороченного затопления. Посев и залив чека провели в оба года 5-8 мая.

Для посева сортов риса в конкурсном испытании использовали селекционную сеялкУ «ВИНТЕРШТАЙГЕР» С центральным высевом. Делянки 8-ми рядковые, с междурядьем 15 см. Площадь делянок 22,5 м² (15 × 1,50). Норма посева 6 млн всхожих зерен на гектар. Повторность четырехкратная, с рендомизированным размещением делянок. В течение вегетации проводили учеты и наблюдения согласно принятой методике.

Перед уборкой, в фазе полной спелости, в делянках обоих сортов отбирали для биометрического анализа по 30 растений с корнями. При этом брали по 10 растений в первом, втором и третьем рядах. Это было сделано специально для получения популяции, гетерогенной по морфологическим признакам. Как правило, в первом ряду делянки развиваются наиболее мощные растения, а в последующих - их мощность снижается ввиду усиления конкурентных взаимоотношений за основные факторы среды. Наблюдается так называемый «корытообразный» эффект, когда более низкие растения находятся в центре, а более высокие на крайних рядах.

После проведения биометрического анализа выделили по 20 растений лучших и худших по признаку «масса метелки». Потомство этих растений высевали в селекционном питомнике 2019 г., который закладывали кассетной сеялкой «ВИНТЕРШТАЙГЕР», однорядковыми делянками длиной 2,5 м с междурядьем 22 см. После созревания риса отбирали по 25 растений со 2-го ряда и проводили биометрический анализ. Полученные данные обрабатывали статистическими методами [1].

В качестве объектов исследований в наших опытах были использованы длиннозерные сорта риса Снежинка и Злата.

Эти сорта включены в Государственный реестр: Снежинка с 2002 г., Злата с 2019 г. Оба сорта относятся к подвиду - indica, разновидности - gilanica. Злата отличается повышенным содержанием амилозы (23-24 \%) [2].

\section{Результаты и обсуждение}

Морфологическая неоднородность популяций растений в пределах сорта описывается методами статистического анализа для лучшей наглядности и информативности. Поэтому полученные данные биометрического анализа растений длиннозерных сортов риса, выращенных в конкурсном испытании, были подвергнуты статистической обработке. Результаты приведены в таблицах 1 и 2.

Биометрические показатели растения характеризуют сорт Снежинка по основным морфологическим признакам. Средняя высота растений составила 110 см и варьировала от 106 до 112 см. При этом коэффициент вариации был довольно низким - 7 \%. Длина метелки составляла в среднем 20,3 см, при крайних показателях от 18 до 25 см. Признак «длина метелки» характеризуется низкой изменчивостью, коэффициент вариации равен 6 \%. По общему числу колосков в метелке сорт относится к достаточно продуктивным. Разброс по этому признаку составляет от 115 до 198 штук колосков в метелке. Коэффициент вариации позволяет отнести этот признак к средне изменчивому.

Показателем продуктивности растения является масса зерна с метелки. У сорта Снежинка масса метелки в среднем составила 3,4 г, с разбросом от 2,7 до 5,2 г. Этот признак по коэффициенту вариации (19 \%) можно отнести к средне изменчивому.

Высокую изменчивость показывает масса зерна с растения: CV равен 27 \%. На разброс показателей этого признака оказывают влияние продуктивная кустистость и стерильность колосков, которые относятся к высоко изменчивым признакам.

Показатель «плотность метелки» составляет 6,8 шт./см, что относит сорт к группе со средней плотностью метелки. 
Таблица 1. Результаты статистической обработки биометрических показателей растений сорта Снежинка, 2018 г.

\begin{tabular}{|l|c|c|c|}
\hline \multicolumn{1}{|c|}{ Признаки } & $\overline{\mathbf{X}} \mathbf{\pm} \mathbf{S} \overline{\mathbf{X}}$ & $\mathbf{L i m}$ & $\mathbf{C V}, \%$ \\
\hline Высота растений, см & $110,0 \pm 3,3$ & $106-112$ & 7 \\
\hline Продуктивная кустистость & $1,7 \pm 0,6$ & $1,1-2,9$ & 22 \\
\hline Длина метелки, см & $20,3 \pm 0,9$ & $18-25$ & 6 \\
\hline Общее число колосков, шт. & $136,5 \pm 26,2$ & $115-198$ & 20 \\
\hline Количество зерен в метелке, шт. & $122,2 \pm 19,9$ & $104-167$ & 17 \\
\hline Масса зерна с главной метелки, г & $3,4 \pm 0,6$ & $2,2-5,2$ & 19 \\
\hline Масса зерна с растения, г & $5,8 \pm 0,9$ & $2,4-14,8$ & 27 \\
\hline Плотность метелки, шт./см & $6,8 \pm 0,4$ & $5,2-8,6$ & 13 \\
\hline Стерильность колосков, \% & $10,5 \pm 2,3$ & $7,6-19,5$ & 28 \\
\hline Отношение длины зерновки к ширине $(/ / b)$ & $3,7 \pm 0,1$ & $3,6-3,9$ & 4 \\
\hline
\end{tabular}

Наименьшей изменчивостью у сорта Снежинка отличается признак «отношение длины зерновки к ширине», у которого CV = 4 \%.

Высота растений сорта Злата составляет в среднем 99 см, при очень низком коэффициенте изменчивости (CV = 6 \%). Длина метелки сорта Злата составляет в среднем 20,9 см, при размахе показателей от
17 до 26 см. Признак длина метелки характеризуется низкой изменчивостью, коэффициент вариации составляет $9 \%$. По общему числу колосков сорт Злата относится к достаточно продуктивным. Разброс по этому признаку составляет от 130 до 194 штук колосков в метелке. Коэффициент вариации позволяет отнести этот признак к средне изменчивому.

Таблица 2. Результаты статистической обработки биометрического анализа растений сорта Злата, 2018 г.

\begin{tabular}{|l|c|c|c|}
\hline \multicolumn{1}{|c|}{ Признаки } & $\overline{\mathbf{X}} \mathbf{\pm} \mathbf{S} \overline{\mathbf{X}}$ & $\mathbf{L i m}$ & $\mathbf{C V}, \%$ \\
\hline Высота растений, см & $99,0 \pm 3,1$ & $96-102$ & 6 \\
\hline Продуктивная кустистость & $1,7 \pm 0,6$ & $1,2-2,9$ & 21 \\
\hline Длина метелки, см & $20,9 \pm 1,3$ & $17-26$ & 7 \\
\hline Общее число колосков, шт. & $161,5 \pm 10,5$ & $130-194$ & 14 \\
\hline Количество зерен в метелке, шт. & $141,7 \pm 7,2$ & $120-170$ & 12 \\
\hline Масса зерна с главной метелки, г & $3,5 \pm 0,5$ & $2,4-5,1$ & 18 \\
\hline Масса зерна с растения, г & $5,9 \pm 0,9$ & $2,9-14,7$ & 26 \\
\hline Плотность, шт./см & $7,7 \pm 0,8$ & $5,6-8,9$ & 11 \\
\hline Стерильность колосков, \% & $8,8 \pm 1,4$ & $7,6-12,2$ & 23 \\
\hline Отношение длины зерновки к ширине $(/ / b)$ & $3,8 \pm 0,1$ & $3,7-4,0$ & 4 \\
\hline
\end{tabular}

Масса зерна с главной метелки в среднем составляла 3,5 г, с разбросом от 2,4 до 4,7 г. Этот признак по коэффициенту вариации (18 \%) можно отнести к средне изменчивому.

Высоко изменчивым признаком у сорта Злата, как и у Снежинки, является масса зерна с растения $(\mathrm{CV}=26 \%)$. А наименее изменчивым признаком является отношение длины зерновки к ширине (l/b).

Показатель плотности метелки составляет 8,6 шт./см, что относит ее к группе со средней плотностью метелки. Стерильность колосков у сорта Злата довольно низкая - 8,8 \%, но по коэффициенту изменчивости этот признак относится к сильно изменчивым. Повышение стерильности колосков в метелках риса является проявлением негативной реакции сорта на условия внешней среды.

Таким образом, в результате проведенного статистического анализа биометрических показателей длиннозерных сортов риса подтверждено, что такие признаки как «высота растения», «длина метелки» и «отношение длины зерновки к ширине» являются мало изменчивыми. По этим признакам оба сорта хорошо выровнены.

А такие признаки как «масса зерна с растения» и «стерильность колосков в метелке», «продуктивная кустистость» являются сильно изменчивыми. Они в значительной мере зависят от условий выращивания сортов риса. Поскольку наследуются не сами признаки, а спектр возможностей развития в зависимости от условий среды (норма реакции генотипа), а на реализацию каждого признака в онтогенезе влияют многие гены, возможность быстрого определения генетической структуры популяции по учету разового соотношения генотипов ограничены. Поэтому в полевых условиях необходимо стремиться создавать оптимальные условия для роста и развития каждому сорту.

После проведенного анализа биометрических показателей растений сортов Снежинки и Злата, мы отобрали по массе зерна с метелки по 20 «лучших» 
и «худших» растений. Их семена высеяли в селекционном питомнике 2019 г. для проверки этих растений по потомству.

Выращенные растения убрали и проанализировали по биометрическим показателям. В данном со- общении мы показали один признак - «массу зерна с главной метелки», который косвенно отражает продуктивность растения. Полученные результаты представлены в таблице 3.

Таблица 3. Средняя масса зерна с главной метелки длиннозерных сортов риса до посева и после уборки в селекционном питомнике, г, урожай 2019 г.

\begin{tabular}{|l|c|c|}
\hline \multicolumn{1}{|c|}{ Группа растений } & Снежинка & 3лата \\
\hline Исходные лучшие & 5,14 & 5,12 \\
\hline Полученное потомство & 4,24 & 2,46 \\
\hline Исходные худшие & 2,37 & 4,45 \\
\hline Полученное потомство & 4,26 & 0,114 \\
\hline HСР $_{05}$ & 0,123 & \\
\hline
\end{tabular}

Согласно данным, представленным в таблице 3, растения сортов риса перед посевом из группы «лучших» имели большую массу зерна с метелки по сравнению с группой «худших»: у сорта Снежинка в 2,17 раза, а у сорта Злата - в 2,12 раза. В полученном потомстве, выращенном в равнозначных условиях, масса зерна с метелки у каждого сорта была практически одинакова. Это свидетельствует о модификационном изменении продуктивности метелок у изученных сортов, выращенных в разных условиях среды в течение предыдущего года.

\section{Выводы}

1. При размножении сортов риса Снежинка и Злата и формировании семеноводческих питомников необходимо учитывать модификационной характер изменчивости количественных признаков.

2. Для воспроизводства сорта необходимо отбирать типичные растения по апробационным малоизменчивым признакам, которые даются в описании сорта.

\section{ЛИТЕРАТУРА}

1. Доспехов, Б.А. Методика полевого опыта с основами статистической обработки результатов исследований. 5-е изд., доп. и перераб / Б.А. Доспехов. - М.: Агропромиздат, 1985. - 351 с.

2. Зеленский, Г.Л. Новый длиннозерный сорт риса Злата / Г.Л. Зеленский, А.Г. Зеленский, Н.Г. Туманьян, Т.А. Ромащенко, Ю.В. Ткаченко // Рисоводство. - Краснодар, 2018. - № 2(39). - С. 38 - 42.

3. Кудряшов, И.Н. Модификационная изменчивость элементов продуктивности колоса пшеницы мягкой озимой / И.Н. Кудряшов, Д.А. Пономарев, Н.И. Лысак, А.В. Михалко, Е.А. Команов // Рисоводство. - Краснодар, 2019. № 2(43). - С. $22-28$.

4. Подольских, А.Н. Влияние сезонных эффектов на формирование признаков различных генотипов риса / А.Н. Подольских // Рисоводство. - Краснодар, 2015. - № 1-2(26-27). - С. 43 - 47.

5. Туганаев, В.В. Состояние агрофитоценозов современного земледелия Волжско-Камского края (1967 - 1977 гг.)/ В. В. Туганаев // Ботанический журнал. - 1979. - Т. 64. - № 12. - С. 1807 - 1812.

6. Angelini, R. II riso / R. Angelini, A. Ferrero, I. Ponti. - Milano: Bayer Crop Science, 2008. - 680 p.

7. Chen, X. China feels the heat: negative impacts of high temperatures on China's rice sector / X. Chen, S. Chen // Australian Journal of Agricultural and Resource Economics. - 2018. - Vol. 62, Is. 4. - P. 576 - 588. https://doi.org/10.1111/14678489.12267.

8. Farooq, H. Rice direct seeding: Experience, challenges and opportunities / H. Farooq [et al.] // Soil and Tillage Research. - 2011. - Vol. 111, Is. 2. - P. 87 - 98.

9. Larcher, W. Physiological plant ecology. - N.Y.: Springer, 1995. -506 p.

10. Wang, Y. Mitigating rice production risks from drought through improving irrigation infrastructure and management in China / Y. Wang, J. Huang, J. Wang, Findlay C. // Australian Journal of Agricultural and Resource Economics. - 2018. Vol. 62, Is. 1. - P. 161 - 176. https://doi.org/10.1111/1467-8489.12241.

\section{REFERENCES}

1. Dospekhov, B.A. The methodology of field experience with the basics of statistical processing of research results. $5^{\text {th }}$ ed. and reslave / B.A. Dospekhov. - M.: Agropromizdat, 1985. -351 p.

2. Zelensky, G.L. New long-grain variety Zlata / G.L. Zelensky, A.G. Zelensky, N.G. Tumanyan, T.A. Romashchenko, Y.V. Tkachenko // Rice growing. - 2018. - № 2(39). - P. $38-42$.

3. Kudryashov, I.N. Modificational variability of elements winter wheat heads productiveness / I.N. Kudryashov, D.A. Ponomarev, A.V. Lisak, A.V. Mikhalko, E.A. Komanov // Rice growing. - 2019. - № 2(43). - P. 22 - 28.

4. Podolskikh, A.N. Seasonal effects on the formation parameters of different rice genotypes / A.N. Podolskikh // Rice growing. - 2015. - № 1-2(26-27). - P. $43-47$. 
5. Tuganaev, V.V. The state of agrophytocoenose's of modern agriculture in Volga-Kama region (1967 - 1977) // Botanic Journal. - 1979. - Vol. 64. - № 12. - P. 1807 - 1812.

6. Angelini, R. II riso / R. Angelini, A. Ferrero, I. Ponti. - Milano: Bayer Crop Science, 2008. - 680 p.

7. Chen, $X$. China feels the heat: negative impacts of high temperatures on China's rice sector / X. Chen, S. Chen // Australian Journal of Agricultural and Resource Economics. - 2018. - Vol. 62, Is. 4. - P. 576 - 588. https://doi.org/10.1111/14678489.12267.

8. Farooq, H. Rice direct seeding: Experience, challenges and opportunities / H. Farooq [et al.] // Soil and Tillage Research. - 2011. - Vol. 111, Is. 2. - P. $87-98$.

9. Larcher, W. Physiological plant ecology. - N.Y.: Springer, 1995. -506 p.

10. Wang, Y. Mitigating rice production risks from drought through improving irrigation infrastructure and management in China / Y. Wang, J. Huang, J. Wang, Findlay C. // Australian Journal of Agricultural and Resource Economics. - 2018. Vol. 62, Is. 1. - P. 161 - 176. https://doi.org/10.1111/1467-8489.12241.

\section{Григорий Леонидович Зеленский}

Главный научный сотрудник

отдела селекции

E-mail: zelensky08@mail.ru

ФГБНУ «ФНЦ риса»

350921, Россия, г. Краснодар, Белозерный, 3

\section{Ольга Всеволодовна Зеленская}

Доцент кафедры ботаники

и общей экологии

E-mail: zelenskayaolga-2011@mail.ru

\section{Кристина Юрьевна Кобинякова}

Магистрант факультета агрономии и экологии

ФГБОУ ВО «Кубанский государственный аграрный университет имени И.Т. Трубилина» 350044, Россия, г. Краснодар, ул. Калинина, 13

\author{
Grigory Leonidovich Zelensky \\ Chief Researcher \\ of the Breeding Department \\ E-mail: zelensky08@mail.ru \\ FSBSI FNC of rice" \\ 3, Belozerny, Krasnodar, 350921, Russia
}

\section{Olga Vsevolodovna Zelenskaya}

Associate Professor at the Department of Botany and General Ecology

E-mail: zelenskayaolga-2011@mail.ru

\section{Kristina Yurievna Kobinyakova}

Master of Faculty Agronomy and Ecology

FSBEl of HE "Kuban State

Agrarian University named after I.T. Trubilin"

13, Kalinina, Krasnodar, 350044, Russia 
DOI: 10.33775/1684-2464-2020-49-4-11-16 УДК 633.854.78: 631.527
Ю.К. Гончарова, д-р биол. наук, Е.М. Харитонов, академик РАН г. Краснодар, Россия С.В. Свинарев г. Волгодонск, Россия

\section{ПОЛИМОРФИЗМ ЛОКУСОВ, ОПРЕДЕЛЯЮЩИХ ПРИЗНАК «ПУСТОЗЕРНОСТЬ»} У ОТЕЧЕСТВЕННЫХ СОРТОВ РИСА ПРИ ВЫСОКИХ ТЕМПЕРАТУРАХ ВОЗДУХА*

В России отмечено повышение средних температур воздуха по сравнению с многолетними данными. Ранее было показано, что увеличение средних температур приводит к снижению продуктивности растений по различным признакам на 20 - 90 \% и урожайности до десяти процентов при ее повышении на $1{ }^{\circ} \mathrm{C}$. Температуры более $35^{\circ} \mathrm{C}$ снижают озерненность метелки, количество колосков и продуктивных стеблей, массу 1000 зерен. Однако, селекция отечественных сортов риса на адаптивность к высоким температурам ранее не проводилась, не изучен и полиморфизм локусов, определяющих признак. Провели фенотипирование 23 отечественных сортов риса по признаку «устойчивость к высоким температурам». Растения контрольного и опытного вариантов выращивали на вегетационной площадке при оптимальных дозах минерального питания $\left(N_{120} P_{60} K_{60}\right)$. Перед началом цветения сосуды с растениями заносили в камеры с температурами 25 и $35^{\circ} \mathrm{C}$. Проведенное фенотипирование позволило разделить сорта на группы с различной устойчивостью к стрессу. Сорта риса были маркированы с использованием пятидесяти молекулярных SSR маркеров, как нейтральных, так и определяющих адаптивность. В результате исследования выявлены участки хромосом риса, определяющие признак «пустозерность» у отечественных сортов риса на первой, пятой, восьмой и двенадцатой хромосомах в регионах локализации маркеров RM600, RM289, RM25, RM6410 соответственно. В выявленных регионах ранее локализованы гены, определяющие размеры корней и процент выполненных зерен, что косвенно подтверждает результаты исследования и говорит о возможном механизме повышения адаптивности за счет стабилизации осмотического баланса.

Ключевые слова: рис, генетика, пустозерность, метелка, устойчивость к стрессам, высокие температуры.

\section{POLYMORPHISM LOCUS DETERMINING TRAIT "EMPTY GRAIN" IN DOMESTIC RICE VARIETIES AT HIGH AIR TEMPERATURES}

In Russia, an increase in average air temperatures was noted in comparison with long-term data. Earlier it was shown that an increase in average temperatures leads to a decrease in the productivity of plants for various characteristics by $20-90 \%$ and a yield of up to ten percent with an increase of $1{ }^{\circ} \mathrm{C}$. Temperatures over $35{ }^{\circ} \mathrm{C}$ reduce the grain content of the panicle, the number of spikelets and productive stems, 1000 grains. However, breeding of domestic rice varieties for adaptability to high temperatures has not been previously carried out, and the polymorphism of the loci determining the trait has not been studied either. Phenotyping of 23 domestic rice varieties was carried out on the basis of "resistance to high temperatures". Plants of the control and experimental variants were grown on vegetation plot with optimal doses of mineral nutrition $\left(N_{120} P_{60} K_{60}\right)$. Before the beginning of flowering, vessels with plants were brought into chambers with temperatures of $25^{\circ} \mathrm{C}$ and $35^{\circ} \mathrm{C}$. The performed phenotyping allowed to divide varieties into groups with different resistance to stress. Rice cultivars were labeled using fifty molecular SSR markers, both neutral and adaptive. As a result of the study, were identified areas of rice chromosomes that determine the "empty grain" trait in domestic rice varieties on the first, fifth, eighth and twelfth chromosomes in regions localization markers RM600, RM289, RM25, RM6410, respectively. In the identified regions, previously were localized genes that determine the size of roots and the percentage of completed grains, which indirectly confirms the results of the study and suggests a possible mechanism for increasing adaptability by stabilizing the osmotic balance.

Key words: rice, genetics, empty grain, panicle, resistance to stress, high temperatures.

\section{Введение}

В последнее время изменение климата затронуло многие регионы мира, среди них и Россия, где также отмечено повышение средних температур воздуха по сравнению с многолетними данными. В литературе показано несколько гипотез, объясняющих потепление климата, одна из них связывает увеличение средней температуры с накоплением парниковых газов (углекислого газа, метана). Климатические модели предсказывают дальнейшее увеличение температур на $4-5^{\circ} \mathrm{C}$ к концу нынешнего столетия [12]. Ранее на рисе и пшенице было показано, что увеличение средних температур приводит к снижению продуктивности растений по различным признакам 
на 20 - 90 \% и урожайности до десяти процентов при ее повышении на $1^{\circ} \mathrm{C}$. Отмечено, что вследствие высоких температур и засухи урожайность многих культур в последние годы снизилась на 5 - 10 \% [8]. Температуры более $35^{\circ} \mathrm{C}$ в фазы кущения и цветения риса снижают озерненность метелки отдельных сортов более чем на 90 \% [2, 9]. Уменьшается также общее количество колосков и продуктивных стеблей, масса 1000 зерен. Есть сообщения о том, что причина низкой озерненности растений - нерастрескивание пыльников и стерильность пыльцы $[1,10]$. Другая стратегия повышения устойчивости к стрессу - более раннее цветение в течение дня или сокращение периода вегетации, позволяющее закончить его до критического для оплодотворения повышения температуры $[5,6]$. На сегодняшний момент выделен ряд источников для повышения устойчивости к стрессу, среди них наиболее известны сорта риса Nagina 22, Dular, Koshihikary, Tokanary. Локусы, определяющие адаптивность к высоким температурам, выявлены на большинстве хромосомах риса. На первой и шестой хромосомах установлено по 2 региона, влияющих на формирование признака. На четвертой хромосоме, картирован локус qHTSF4.1, который увеличивает озерненность метелки на пятнадцать процентов, аллель с положительным эффектом на признак выявлен у сорта Нагина 22. Помимо этого локуса выявлен ряд минорных QTL на других хромосомах [3, 7]. В таблице 1 мы обобщили литературные данные по локализации хромосомных регионов определяющих признак [11, 14]. Однако селекция отечественных сортов риса на адаптивность к высоким температурам ранее не проводилась, не изучен и полиморфизм локусов, определяющих признак.

\section{Таблица 1. Хромосомные регионы, определяющие признак «устойчивость к высоким} температурам» у риса

\begin{tabular}{|c|c|c|}
\hline \multirow{2}{*}{ Хромосома } & \multicolumn{2}{|c|}{ Фланкирующие регион микросателлитные маркеры } \\
\hline & Forward & Revers \\
\hline \multirow{2}{*}{ первая } & RM 5423 & RM5365 \\
\hline & RM7594 & RM6321 \\
\hline вторая & RM6842 & RM5699 \\
\hline третья & RM1350-1 & RM7389 \\
\hline четвертая & RM 5633 & RM 16828 \\
\hline пятая & RM 6034 & RM 3476 \\
\hline \multirow{2}{*}{ шестая } & RM 1370 & RM 5453-1 \\
\hline & RM 3408 & RM 7193 \\
\hline восьмая & RM 3634 & RM 4997 \\
\hline девятая & RM 3907 & RM 5657 \\
\hline двенадцатая & RM 7102-1 & RM 1226 \\
\hline
\end{tabular}

\section{Цель исследований}

Выявить локусы, определяющие признак «пустозерность» у отечественных сортов риса при воздействии высоких температур.

\section{Материалы и методы}

Фенотипирование 23 отечественных сортов риса по признаку проводили с 2013 по 2016 гг. (табл. 2).

Растения контрольного и опытного вариантов выращивали на вегетационной площадке при оптимальных дозах минерального питания $\left(\mathrm{N}_{120} \mathrm{P}_{60} \mathrm{~K}_{60}\right)$. Перед началом цветения сосуды с растениями (10 шт. на сосуд) заносили в камеры. Выборка - 20 растений сорта на вариант опыта. Для выделения ДНК из проростков и листьев риса использовали STAB-метод с модификациями. Полимеразную цепную реакцию (ПЦР) и анализ полученного продукта амплификации проводили по методике Международного института риса [12]. В эксперименте использованы следующие параметры ПЦР: начальная денатурация пять минут при $94{ }^{\circ} \mathrm{C}$, тридцать пять циклов: 60 сек. - денатурация $94^{\circ} \mathrm{C}$, 60 сек. - отжиг праймеров при $55^{\circ} \mathrm{C}$, 120 сек - синтез $72{ }^{\circ} \mathrm{C}$; элонгация -420 сек. $72{ }^{\circ} \mathrm{C}$. Объем ПЦР реакции - 10 мкл: ДНК - 2 мкл), 1 мкл
(1 мМ) дезоксинуклеотидтрифосфатов; 3,7 мкл $\mathrm{H}_{2} \mathrm{O}$; 1 мкл - раствора ПЦР буфера, 0,5 мкл - каждого праймера, 1 мкл - Таq-полимеразы. Электрофорез проводили с использованием полиакриламидного геля при напряжении 100 V. Обработка данных велась в программе Statistica 10, для маркирования использовали метод групповой селекции $[4,13]$. Изучаемые маркеры были распределены по всем 12 хромосомам риса.

\section{Результаты и обсуждение}

Проведенное фенотипирование позволило разделить сорта на группы с различной устойчивостью к стрессу (табл. 2). Сорта риса были маркированы с использованием пятидесяти молекулярных SSR маркеров, как нейтральных, так и определяющих адаптивность.

Дисперсионный анализ позволил установить связь между устойчивостью к стрессу и вариабельностью сортов по отдельным SSR маркерам (табл. 3). Поскольку генплазма в исследовании генетически разнородна, в работе могли быть выявлены локусы с наиболее значительным вкладом в фенотип. Влияние генотипа сорта на проявление признака не учитывали. 
Таблица 2. Влияние температуры воздуха на признак «пустозерность» сортов риса

\begin{tabular}{|c|c|c|c|}
\hline \multirow{2}{*}{ Сорт } & \multicolumn{2}{|c|}{ Пустозерность,\% } & \multirow{2}{*}{$\begin{array}{c}\text { Размах } \\
\text { изменчивости, \% }\end{array}$} \\
\hline & КИК, t $35^{\circ} \mathrm{C}$ & контроль & \\
\hline ВНИИР 8242 & 95,6 & $32,6^{\star}$ & 63,0 \\
\hline Аметист & 40,1 & $19,0^{*}$ & 21,2 \\
\hline Атлант & 59,9 & $18,1^{*}$ & 41,8 \\
\hline Боярин & 64,6 & $23,3^{*}$ & 41,3 \\
\hline Гарант & 91,2 & $11,6^{*}$ & 79,6 \\
\hline Дружный & 47,5 & 40,5 & 7,0 \\
\hline Жемчуг & 48,6 & $19,7^{*}$ & 29,0 \\
\hline Изумруд & 76,6 & $33,6^{*}$ & 43,0 \\
\hline Касун & 75,1 & $39,2^{*}$ & 35,9 \\
\hline Курчанка & 79,1 & $53,7^{*}$ & 25,4 \\
\hline Лиман & 40,1 & $21,6^{*}$ & 18,5 \\
\hline Нарцисс & 98,3 & $65,0^{*}$ & 33,4 \\
\hline Новатор & 62,1 & 50,7 & 11,4 \\
\hline Павловский & 42,5 & 31,1 & 11,4 \\
\hline Регул & 70,2 & $37,9^{*}$ & 32,3 \\
\hline Садко & 91,2 & $62,1^{*}$ & 29,1 \\
\hline Серпантин & 46,0 & 40,8 & 5,2 \\
\hline Снежинка & 91,1 & $31,0^{*}$ & 60,0 \\
\hline Спринт & 78,2 & $21,8^{*}$ & 56,3 \\
\hline Стрелец & 62,8 & 64,2 & $-1,4$ \\
\hline Факел & 68,4 & $32,4^{*}$ & 36,1 \\
\hline Фонтан & 73,1 & $21,1^{*}$ & 52,0 \\
\hline Хазар & 91,3 & $32,2^{*}$ & 59,2 \\
\hline Ханкайский & 90,4 & $29,1^{*}$ & 61,3 \\
\hline Юпитер & 44,7 & $38,7^{\star}$ & 6,0 \\
\hline $\mathrm{cp}$ & 69,2 & $34,8^{*}$ & 35,8 \\
\hline Max & 98,3 & $65,0^{*}$ & 79,6 \\
\hline МИн & 40,1 & 11,6 & $-1,4$ \\
\hline
\end{tabular}

Примечание: * - статистически достоверно при $P<0,05$

Таблица 3. Дисперсионный анализ связи между устойчивостью к стрессу и полиморфизмом сортов риса по SSR маркерам

\begin{tabular}{|c|c|c|c|c|c|c|c|c|}
\hline & Сум.кв. & Ст.св. & Ср.кв. & Сум.кв. & Ст.св. & Ср.кв. & F & p \\
\hline RM240 & 0,78788 & 1 & 0,78788 & 26,5455 & 22 & 1,20661 & 0,65297 & 0,42770 \\
\hline RM405 & 1,26923 & 1 & 1,26923 & 27,2308 & 22 & 1,23776 & 1,02542 & 0,32224 \\
\hline RM136 & 0,53875 & 1 & 0,53875 & 4,4196 & 22 & 0,20089 & 2,68183 & 0,11572 \\
\hline RM154 & 0,16783 & 1 & 0,16783 & 7,8322 & 22 & 0,35601 & 0,47143 & 0,49950 \\
\hline RM162 & 5,79283 & 1 & 5,79283 & 61,8322 & 22 & 2,81055 & 2,06110 & 0,16516 \\
\hline RM104 & 0,22844 & 1 & 0,22844 & 5,1049 & 22 & 0,23204 & 0,98447 & 0,33188 \\
\hline RM140 & 0,00466 & 1 & 0,00466 & 3,3287 & 22 & 0,15130 & 0,03081 & 0,86226 \\
\hline RM141 & 0,15414 & 1 & 0,15414 & 17,8042 & 22 & 0,80928 & 0,19046 & 0,66678 \\
\hline RM82 & 1,55274 & 1 & 1,55274 & 62,4056 & 22 & 2,83662 & 0,54739 & 0,46720 \\
\hline RM126 & 0,07459 & 1 & 0,07459 & 5,2587 & 22 & 0,23903 & 0,31206 & 0,58206 \\
\hline RM53 & 0,42075 & 1 & 0,42075 & 7,4126 & 22 & 0,33694 & 1,24874 & 0,27584 \\
\hline RM255 & 0,04924 & 1 & 0,04924 & 0,9091 & 22 & 0,04132 & 1,19167 & 0,28680 \\
\hline RM13 & 0,28001 & 1 & 0,28001 & 5,6783 & 22 & 0,25811 & 1,08487 & 0,30892 \\
\hline RM25 & 0,44318 & 1 & 0,44318 & 2,1818 & 22 & 0,09917 & 4,46875 & 0,04608 \\
\hline RM227 & 0,00117 & 1 & 0,00117 & 1,8322 & 22 & 0,08328 & 0,01399 & 0,90690 \\
\hline RM286 & 0,37762 & 1 & 0,37762 & 33,6224 & 22 & 1,52829 & 0,24709 & 0,62406 \\
\hline RM542 & 0,09441 & 1 & 0,09441 & 4,4056 & 22 & 0,20025 & 0,47143 & 0,49950 \\
\hline
\end{tabular}


Продолжение таблицы 3

\begin{tabular}{|c|c|c|c|c|c|c|c|c|}
\hline & Сум.кв. & Ст.св. & Ср.кв. & Сум.кв. & Ст.св. & Ср.кв. & F & p \\
\hline RM509 & 0,09441 & 1 & 0,09441 & 6,4056 & 22 & 0,29116 & 0,32424 & 0,57484 \\
\hline RM590 & 0,14103 & 1 & 0,14103 & 1,6923 & 22 & 0,07692 & 1,83333 & 0,18948 \\
\hline RM261 & 0,14103 & 1 & 0,14103 & 1,6923 & 22 & 0,07692 & 1,83333 & 0,18948 \\
\hline RM276 & 0,01428 & 1 & 0,01428 & 5,9441 & 22 & 0,27018 & 0,05284 & 0,82031 \\
\hline RM24 & 0,04924 & 1 & 0,04924 & 0,9091 & 22 & 0,04132 & 1,19167 & 0,28680 \\
\hline RM600 & 31,5387 & 1 & 31,53875 & 60,4196 & 22 & 2,74634 & 11,4839 & 0,00264 \\
\hline RM242 & 0,01428 & 1 & 0,01428 & 3,9441 & 22 & 0,17928 & 0,07964 & 0,78042 \\
\hline RM3276 & 0,02360 & 1 & 0,02360 & 8,6014 & 22 & 0,39097 & 0,06037 & 0,80819 \\
\hline RM5361 & 0,10519 & 1 & 0,10519 & 12,8531 & 22 & 0,58423 & 0,18004 & 0,67545 \\
\hline RM5508 & 1,04895 & 1 & 1,04895 & 92,9510 & 22 & 4,22505 & 0,24827 & 0,62324 \\
\hline RM6024 & 0,02360 & 1 & 0,02360 & 2,6014 & 22 & 0,11825 & 0,19960 & 0,65941 \\
\hline RM2770 & 0,05711 & 1 & 0,05711 & 41,7762 & 22 & 1,89892 & 0,03007 & 0,86390 \\
\hline RM3155 & 0,03526 & 1 & 0,03526 & 8,9231 & 22 & 0,40559 & 0,08693 & 0,77088 \\
\hline RM7110 & 2,57459 & 1 & 2,57459 & 37,2587 & 22 & 1,69358 & 1,52021 & 0,23060 \\
\hline RM3428 & 0,02360 & 1 & 0,02360 & 4,6014 & 22 & 0,20915 & 0,11284 & 0,74011 \\
\hline RM5371 & 3,21241 & 1 & 3,21241 & 69,4126 & 22 & 3,15512 & 1,01816 & 0,32392 \\
\hline RM6314 & 0,22844 & 1 & 0,22844 & 3,1049 & 22 & 0,14113 & 1,61862 & 0,21656 \\
\hline RM6811 & 0,07459 & 1 & 0,07459 & 21,2587 & 22 & 0,96631 & 0,07719 & 0,78373 \\
\hline RM5638 & 0,69959 & 1 & 0,69959 & 19,2587 & 22 & 0,87540 & 0,7991 & 0,38101 \\
\hline RM5707 & 2,46620 & 1 & 2,46620 & 26,8671 & 22 & 1,22123 & 2,0194 & 0,16931 \\
\hline RM6410 & 1,86480 & 1 & 1,86480 & 3,4685 & 22 & 0,15766 & 11,827 & 0,00234 \\
\hline RM463 & 0,09666 & 1 & 0,09666 & 5,2077 & 21 & 0,24799 & 0,3897 & 0,53914 \\
\hline RM289 & 0,84965 & 1 & 0,84965 & 3,6503 & 22 & 0,16592 & 5,1206 & 0,03385 \\
\hline
\end{tabular}

Примечание: Сум. кв. - сумма квадратов, Ст. св. - степень свободы, Ср. кв. - средний квадрат, F-критерий Фишера, $P$ - уровень значимости

Но, даже с такими допущениями мы выделили четыре хромосомных региона, достоверно (на уровне значимости 0,05) вносящих вклад в формирование признака у отечественных сортов на первой, пятой, восьмой и двенадцатой хромосомах в регионах локализации маркеров RM600, RM289, RM25, RM6410 соответственно (рис. 1).
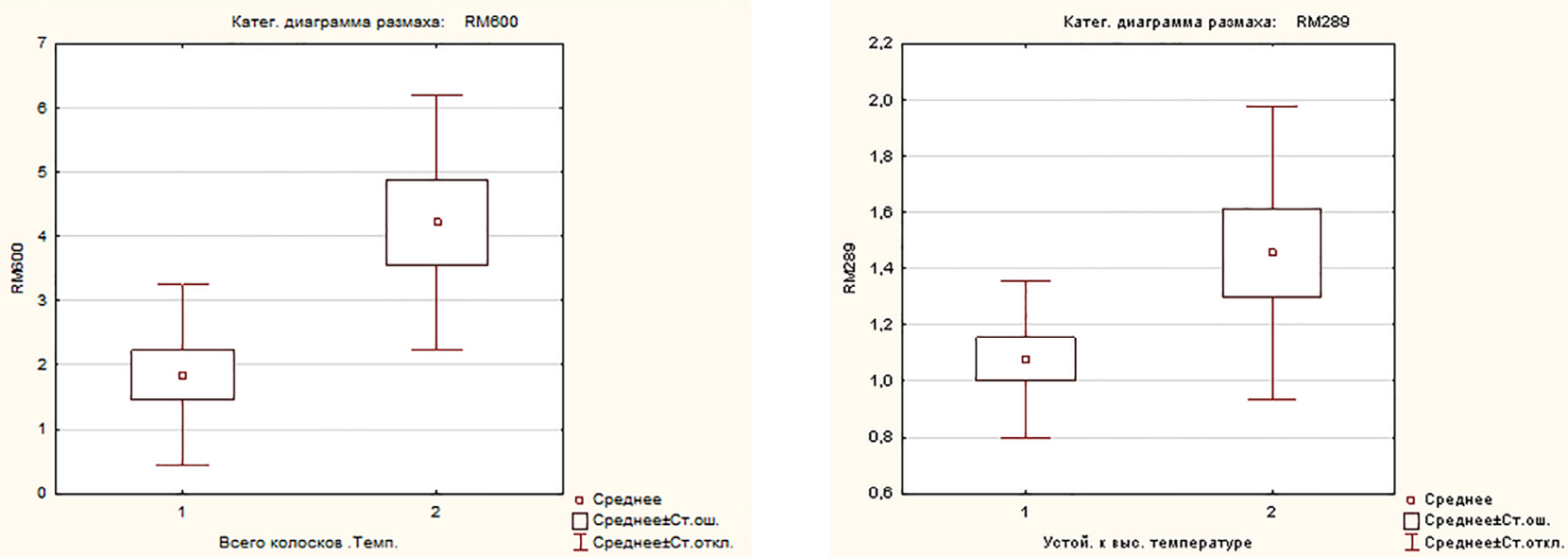

Рисунок 1. Разделение сортов риса на контрастные по устойчивости к стрессу группы с использованием выделенных в работе SSR маркеров а) RM 600, б) RM289

На восьмой хромосоме в выявленном регионе по литературным данным (gramene.org) уже были локализованы гены, определяющие размеры корней и процент выполненных зерен pss8.1(seed set percent). На пятой и первой хромосомах также мар- кированы локусы qRTV5-1 (root volume), qGPA5(seed number), qTRN1-2 (root number), определяющие параметры корневой системы и озерненность метелки, что косвенно подтверждает результаты исследования и говорит о возможном механизме повышения 
адаптивности за счет стабилизации осмотического баланса.

\section{Выводы}

1. Выявлено четыре хромосомных участка, достоверно (при уровне значимости 0,05) способствующих формированию признака у отечественных сортов риса на первой, пятой, восьмой и двенадцатой хромосомах в регионах локализации мар- керов RM600, RM289, RM25, RM6410 соответственно.

2. В выявленных регионах ранее локализованы гены, определяющие размеры корней и процент выполненных зерен, что косвенно подтверждает результаты исследования и говорит о возможном механизме повышения адаптивности за счет стабилизации осмотического баланса.

\section{ЛИТЕРАТУРА}

1. Goncharova, J.K. Inheritance of heat resistance in rice / J.K. Goncharova // Russian Jurnal of Genetics: Applied Research, 2011. - Vol. 3. - P. $248-251$.

2. Goncharova, J.K. Rice Tolerance to the Impact of High Temperatures / J.K. Goncharova, E.M. Kharitonov // Agricultural Research Updates, 2015. - Vol. 9. - P. 1 - 37.

3. Hirabayashi, H. qEMF3, a novel QTL for the early-morning flowering trait from wild rice, Oryza officinalis, to mitigate heat stress damage at flowering in rice, O. sativa / H. Hirabayashi, K. Sasaki, T. Kambe, R.B. Gannaban, M.A. Miras, M.S. Mendioro, E.V. Simon, P.D. Lumanglas, D. Fujita, Y. Takemoto-Kuno, Y. Takeuchi, R. Kaji, M. Kondo, N. Kobayashi, T. Ogawa, I. Ando, K.S. Jagadish \& T. Ishimaru // Journal of Experimental Botany. - 2015. - 66(5). - P. 1227 - 1236. https:// doi. org/10.1093/jxb/eru474.

4. Ishimaru, T. Breeding efforts to mitigate damage by heat stress to spikelet sterility and grain quality / T. Ishimaru, H. Hirabayashi, K. Sasaki, C. Ye, A. Kobayashi // Plant Production Science. - 2016. - 19(1). - P. 12 - 21. https://doi.org/10.1080/ 1343943X.2015.1128113.

5. Jagadish, S.V. Rice responses to rising temperatures-challenges, perspectives and future directions / S.V. Jagadish, K. Murty, W.P. Quick // Plant, Cell and Environment. - 2015. - 38(9). - P. 1686 - 1698. https://doi.org/10.1111/pce.12430.

6. Kobayashi, A. Koshihikari: A premium short-grain rice cultivar - its expansion and breeding in Japan / A. Kobayashi, K. Hori, T. Yamamoto, M. Yano // Rice. - 2018. - 11(1). - P. 15. https://doi.org/ 10.1186/s12284-018-0207-4.

7. Kobayashi, K. Percentage of dehisced thecae and length of dehiscence control pollination stability of rice cultivars at high temperatures / Plant Production Science. - 2011. - 14(2). - P. 89 - 95. https://doi.org/10.1626/pps.14.89.

8. Lesk, C. Influence of extreme weather disasters on global crop production / C. Lesk, P. Rowhani \& N. Ramankutty // Nature. - 2016. - 529(7584) - P. 84 - 87. https://doi.org/10.1038/nature16467.

9. Mackill, D.J. Pollen Shedding and Combining Ability for High Temperature Tolerance in Rice / D.J. Mackill, N.W. Coffma, J. N. Rutger // Crop Science. - 1982. - 22(4). - P. 730 - 733. https://doi. org/10.2135/cropsci1982. 0011183X002200040008x.

10. Matsui, T. Effect of long anther dehiscence on seed set at high temperatures during flowering in rice (Oryza sativa L.) / T. Matsui \& T. Hasegawa // Scientific Reports. - 2019. - 9(1). - P. 20363. https:// doi.org/10.1038/s41598-019-56792-2. 11. Tenorio, F.A., Screening rice genetic resources for heat tolerance / F.A. Tenorio, C. Ye, E. Redona, S. Sierra, M. Laza, M.A. Argayoso // SABRAO Journal of Breeding and Genetics. - 2013. - 45(3). - P. 371 - 381.

12. Van Vuuren, D.P. Temperature increase of $21^{\text {st }}$ century mitigation scenarios / D.P. Van Vuuren, M. Meinshausen, G.K. Plattner, F. Joos, K.M. Strassmann, S.J. Smith, T.M. Wigley, S.C. Raper, K. Riahi, F. de la Chesnaye, M.G. den Elzen, J. Fujino, K. Jiang, N. Nakicenovic, S. Paltsev \& J.M. Reilly // Proceedings of National Academy of Sciences of the United States of America. - 2008. - 105(40). - P. 15258 - 15262. https://doi.org/10. 1073/pnas.0711129105.

13. Xiao, Y.H. Quantitative trait loci associated with seed set under high temperature stress at the flowering stage in rice (Oryza sativa L.) / Y.H. Xiao, Y. Pan, L.H. Luo, G.L. Zhang, H.B. Deng, L.Y. Dai, X.L. Liu, W.B. Tang, L.Y. Chen, G.L. Wang // Euphytica. - 2011. - 178(3). - P. 331 - 338. https://doi.org/10. 1007/s10681-010-0300-2.

14. Ye, C. Finemapping and validating qHTSF4.1 to increase spikelet fertility under heat stress at flowering in rice / C. Ye, F.A. Tenorio, E.D. Redona, P.S. Morales-Cortezano, G.A. Cabrega, K.S. Jagadish \& G.B. Gregorio // Theoretical and Applied Genetics. - 2015. - 128(8). - P. 1507. https://doi.org/10.1007/s00122-015-2526-9.

\section{REFERENCES}

1. Goncharova, J.K. Inheritance of heat resistance in rice / J. K. Goncharova // Russian Jurnal of Genetics: Applied Research. - 2011. - Vol. 3. - P. $248-251$.

2. Goncharova, J.K. Rice Tolerance to the Impact of High Temperatures / J.K. Goncharova, E.M. Kharitonov // Agricultural Research Updates. - 2015. - Vol. 9. - P. 1 - 37.

3. Hirabayashi, H. qEMF3, a novel QTL for the early-morning flowering trait from wild rice, Oryza officinalis, to mitigate heat stress damage at flowering in rice, O. sativa / H. Hirabayashi, K. Sasaki, T. Kambe, R.B. Gannaban, M.A. Miras, M.S. Mendioro, E.V. Simon, P.D. Lumanglas, D. Fujita, Y. Takemoto-Kuno, Y. Takeuchi, R. Kaji, M. Kondo, N. Kobayashi, T. Ogawa, I. Ando, K.S. Jagadish \& T. Ishimaru // Journal of Experimental Botany. - 2015. - 66(5). - P. 1227 - 1236. https:// doi. org/10.1093/jxb/eru474.

4. Ishimaru, T. Breeding efforts to mitigate damage by heat stress to spikelet sterility and grain quality / T. Ishimaru, H. Hirabayashi, K. Sasaki, C. Ye, A. Kobayashi // Plant Production Science. - 2016. - 19(1). - P. 12 - 21. https://doi.org/10.1080/ 1343943X.2015.1128113. 
5. Jagadish, S.V. Rice responses to rising temperatures -challenges, perspectives and future directions / S.V. Jagadish, K. Murty, W.P. Quick // Plant, Cell and Environment. - 2015. - 38(9). - P. 1686 - 1698. https://doi.org/10.1111/pce.12430.

6. Kobayashi, A. Koshihikari: A premium short-grain rice cultivar - its expansion and breeding in Japan / A. Kobayashi, K. Hori, T. Yamamoto, M. Yano // Rice. - 2018. - 11(1). - P. 15. https://doi.org/ 10.1186/s12284-018-0207-4.

7. Kobayashi, K. Percentage of dehisced thecae and length of dehiscence control pollination stability of rice cultivars at high temperatures / Plant Production Science. - 2011. - 14(2). - P. 89 - 95. https://doi.org/10.1626/pps.14.89.

8. Lesk, C. Influence of extreme weather disasters on global crop production / C. Lesk, P. Rowhani \& N. Ramankutty // Nature. - 2016. - 529(7584) - P. 84 - 87. https://doi.org/10.1038/nature16467.

9. Mackill, D.J. Pollen Shedding and Combining Ability for High Temperature Tolerance in Rice / D.J. Mackill, N.W. Coffma, J.N. Rutger // Crop Science. - 1982. - 22(4). - P. 730 - 733. https://doi. org/10.2135/cropsci1982.0011183X002200040008x.

10. Matsui, T. Effect of long anther dehiscence on seed set at high temperatures during flowering in rice (Oryza sativa

L.) / T. Matsui \& T. Hasegawa // Scientific Reports. - 2019. - 9(1). - P. 20363. https:// doi.org/10.1038/s41598-019-56792-2.

11. Tenorio, F.A., Screening rice genetic resources for heat tolerance / F.A. Tenorio, C. Ye, E. Redona, S. Sierra, M. Laza, M.A. Argayoso // SABRAO Journal of Breeding and Genetics. - 2013. - 45(3). - P. 371 - 381.

12. Van Vuuren, D.P. Temperature increase of 21 st century mitigation scenarios / D.P. Van Vuuren, M. Meinshausen, G.K. Plattner, F. Joos, K.M. Strassmann, S.J. Smith, T.M. Wigley, S.C. Raper, K. Riahi, F. de la Chesnaye, M.G. den Elzen, J. Fujino, K. Jiang, N. Nakicenovic, S. Paltsev \& J.M. Reilly // Proceedings of National Academy of Sciences of the United States of America. - 2008. - 105(40). - P. 15258 - 15262. https://doi.org/10. 1073/pnas.0711129105.

13. Xiao, Y.H. Quantitative trait loci associated with seed set under high temperature stress at the flowering stage in rice (Oryza sativa L.) / Y.H. Xiao, Y. Pan, L.H. Luo, G.L. Zhang, H.B. Deng, L.Y. Dai, X.L. Liu, W.B. Tang, L.Y. Chen, G.L. Wang // Euphytica. - 2011. - 178(3). - P. 331 - 338. https://doi.org/10.1007/s10681-010-0300-2.

14. Ye, C. Finemapping and validating qHTSF4.1 to increase spikelet fertility under heat stress at flowering in rice / C. Ye, F.A. Tenorio, E.D. Redona, P.S. Morales-Cortezano, G.A. Cabrega, K.S. Jagadish \& G.B. Gregorio // Theoretical and Applied Genetics. - 2015. - 128(8). - P. 1507. https://doi.org/10.1007/s00122-015-2526-9.

\section{Юлия Константиновна Гончарова}

Заведующая лабораторией генетики и гетерозисной селекции

E-mail: yuliya_goncharova_20@mail.ru

\section{Евгений Михайлович Харитонов}

Научный руководитель

E-mail: evgeniyharitonov46@mail.ru

Все: ФГБНУ «ФНЦ риса», 350921, Россия, г. Краснодар, пос. Белозерный, 3

\section{Сергей Викторович Свинарёв}

Преподаватель кафедры специальных дисциплин E-mail: squire@inbox.ru

ВФ ФГКОУ ВО РЮИ МВД России, 347360, Ростовская область, г. Волгодонск, ул. Степная, 40

\author{
Julia Konstantinovna Goncharova \\ Head of the Laboratory of Genetics \\ and heterosis Selection \\ E-mail: yuliya_goncharova_20@mail.ru
}

\section{Evgeny Mikhailovich Kharitonov}

Scientific director

E-mail: evgeniyharitonov46@mail.ru

All: FSBSI "FSC of rice",

3, Belozerny, Krasnodar, 350921, Russia

\section{Sergey Viktorovich Svinaryev}

Teacher of the Department of special disciplines

E-mail: squire@inbox.ru

VF FGKOU VO RLI Ministry of Internal Affairs of Russia, 40, st. Stepnaya, Volgodonsk, Rostov region, 347360, Russia 


\section{РЕЗУЛЬТАТЫ СЕЛЕКЦИОННОЙ ОЦЕНКИ ПЕРСПЕКТИВНЫХ ДИГАПЛОИДНЫХ ЛИНИЙ РИСА, ПОЛУЧЕННЫХ В КУЛЬТУРЕ ПЫЛЬНИКОВ IN VITRO}

Рис - одна из важнейших культур в сельскохозяйственном производстве Приморского края. В селекционных программах рисосеющих стран мира широко и успешно применяется культура пыльников in vitro. Использование линий удвоенных гаплоидов в качестве исходного гомозиготного материала повышает эффективность селекции, позволяет сократить временные и трудовые затраты. Цель исследования - оценить дигаплоидные растения из гибридов второго поколения по хозяйственно ценным признакам и отобрать перспективные линии для включения их в селекционный процесс. Исследования проводились в ФГБНУ «ФНЦ агробиотехнологий Дальнего Востока им. А.К. Чайки», в 2015 - 2018 гг. Дигаплоидные популяции получены из восьми гибридов первого и второго поколений. Первое поколение из семян регенерантов выращивали в условиях вегетационной площадки, а последующие поколения изучались в условиях полевого опыта. В течение вегетационного периода проводились фенологические наблюдения, а также проводили жесткую браковку позднеспелых, низкоурожайных, полегающих и т.д. линий. Определяли биометрические показатели по основным элементам продуктивности. Использовали такие статистические параметры как среднее значение, стандартное отклонение (ошибка среднего) и коэффициент вариации (V). В результате исследования, нами выделены 4 перспективные дигаплоидные линии четвертого поколения (R4), полученные из двух разных генотипов: Хазар х Дарий 23 и Луговой х Вираж. Выделенные дигаплоидные линии показали низкие коэффициенты изменчивости признаков, а так же превосходили гибридные растения и стандарт по количеству зёрен с главной метёлки, продуктивности растения, массе 1000 штук и урожайности.

Ключевые слова: рис, гибридная комбинация, культура пыльников, in vitro, дигаплоидные линии, продуктивность.

\section{THE RESULTS OF THE SELECTION DIHAPLOIDS EVALUATION OF PROMISING LINES OF RICE OBTAINED IN THE ANTHER CULTURE IN VITRO}

Rice is one of the most important crops in agricultural production in the Primorsky Krai. Breeding programs of rice-sowing countries widely and successfully use in vitro anther culture. Using lines of doubled haploids as source homozygous material increases the efficiency of selection and reduces time and labor costs. The purpose of the study is to evaluate dihaploid plants from second-generation hybrids based on economically valuable traits and to select promising lines to include them in the selection process. The studies were conducted in FSBSI "FSC of Agricultural Biotechnology of the Far East named after A.K. Chaika", in 2015 - 2018. Dihaploid populations were obtained from 8 hybrids of the first and second generations. The first generation from regenerant seeds was grown in a growing area, and subsequent generations were studied in a field experiment. During the growing season, phonological observations were carried out, as well as strict rejection of late-ripening, low-yielding, lodging, etc.lines. There were also defined biometric indicators of the productivity main elements. There were used such statistical parameters as average, standard deviation (average error) and coefficient of variation (V). As a result of the study, 4 promising dihaploid lines of the fourth generation (R4), obtained from two different genotypes were selected: Khazar x Dariy 23 and Lugovoy $x$ Virazh. The selected dihaploid lines showed low coefficients of variability of traits, and also exceeded hybrid plants and standard in the number of grains per panicle, plant productivity, weight of 1000 pieces and yield.

Key words: rice, hybrid combination, anther culture, in vitro, dihaploid lines, productivity.

\section{Введение}

Рис - одна из важнейших продовольственных культур на юге Дальнего Востока России. Почвенноклиматические условия здесь отличаются от условий юга России, где находятся основные площади посевов риса, они ограничивают время вегетации растений низкими летними температурами и неустойчивым муссонным климатом [6].

Создание высокоурожайных сортов риса, приспособленных к условиям дальневосточной зоны, является главной задачей селекции [1]. Генетическая однородность также является необходимым требованием для регистрации новых сортов во многих странах мира. В традиционной селекции подобная однородность обычно достигается путем отбора гомозиготных линий в течение нескольких поколений $[8,9]$.

В настоящее время в селекции риса широко используют метод гаплоидной биотехнологии, позволяющий повысить результативность селекционного 
процесса. Наиболее эффективным является метод культуры пыльников для получения дигаплоидных линий, который позволяет достичь гомозиготности в одном поколении и, следовательно, увеличивает эффективность отборов, что значительно в селекции новых сортов [7, 10].

В последние годы в ФГБНУ «ФНЦ агробиотехнологий Дальнего Востока им. А.К. Чайки» проводятся исследования с целью создания регенерантных линий в культуре пыльников гибридов и сортов риса для ускорения селекционного процесса и повышения его эффективности [3].

\section{Цель исследований}

Оценить дигаплоидные растения из гибридов второго поколения по хозяйственно ценным признакам и отобрать перспективные линии для включения их в селекционный процесс.

\section{Материалы и методы}

Исследования проводились в 2015 - 2018 гг. В работе использовались 8 гибридных комбинаций $\mathrm{F}_{1}$ и $\mathrm{F}_{2}$, из которых лабораторией биотехнологии ФГБНУ «ФНЦ агробиотехнологий Дальнего Востока им. А.К. Чайки» были получены дигаплоидные растения-регенеранты $\left(\mathrm{R}_{1}\right)$, потомство одного растения давало начало новой линии. В 2015 г. лабораторией биотехнологии нам было передано 290 линий регенерантов. Объектом исследования служили: 1 линия из гибридной комбинации Хазар х Дарий 23 и 3 линии - Луговой х Вираж.

Первое поколение $\left(\mathrm{R}_{1}\right)$ из семян регенерантов выращивали в условиях вегетационной площадки в сосудах размером 1,54 м², в качестве контроля использовали родительские формы.

В 2016 - 2017 гг. изучаемый материал $\left(R_{2}-R_{3}\right)$ находился в полевых условиях в питомнике дига- плоидов, в 2018 году дигаплоидные линии четвёртого поколения (R4) выращивались в селекционном питомнике на делянках до 1,5 м², стандартом служил используемый ГСИ Приморского края сорт Приморский 29.

Опыты были заложены по методике селекционных работ ФНЦ риса [4]. Учеты, наблюдения и оценка проводились согласно методике Госсортоиспытания [5]. Определяли биометрические показатели по основным элементам продуктивности. Для характеристики агрономических признаков использовали такие статистические параметры как среднее значение, стандартное отклонение (ошибка среднего) и коэффициент вариации (V). Достоверность различий средних вариантных линий и гибридных популяций устанавливали по критерию Стьюдента при уровне значимости 0,05 [2].

Во всех питомниках $\mathrm{R}_{1}-\mathrm{R}_{3}$ проводили жесткую браковку позднеспелых, восприимчивых к пирикуляриозу, осыпающихся образцов, имеющих склонность к полеганию и т.д.

Погодные условия вегетационного периода в 2015 и 2016 гг. в целом соответствовали биологическим требованиям культуры риса.

Следует отметить, что 2017 год был особенно сложным по метеоусловиям. Осадков выпало больше нормы на 52 - 140 мм, в августе из-за большого количества осадков (208 мм за 4 часа - 7.08.) посевы риса находились под слоем воды в течение 3-х дней (рис. 1). Это повлияло на формирование метелок сортов у которых в этот период наступила фаза выметывания - цветения, в результате чего до 60 \% увеличилась стерильность колосков.

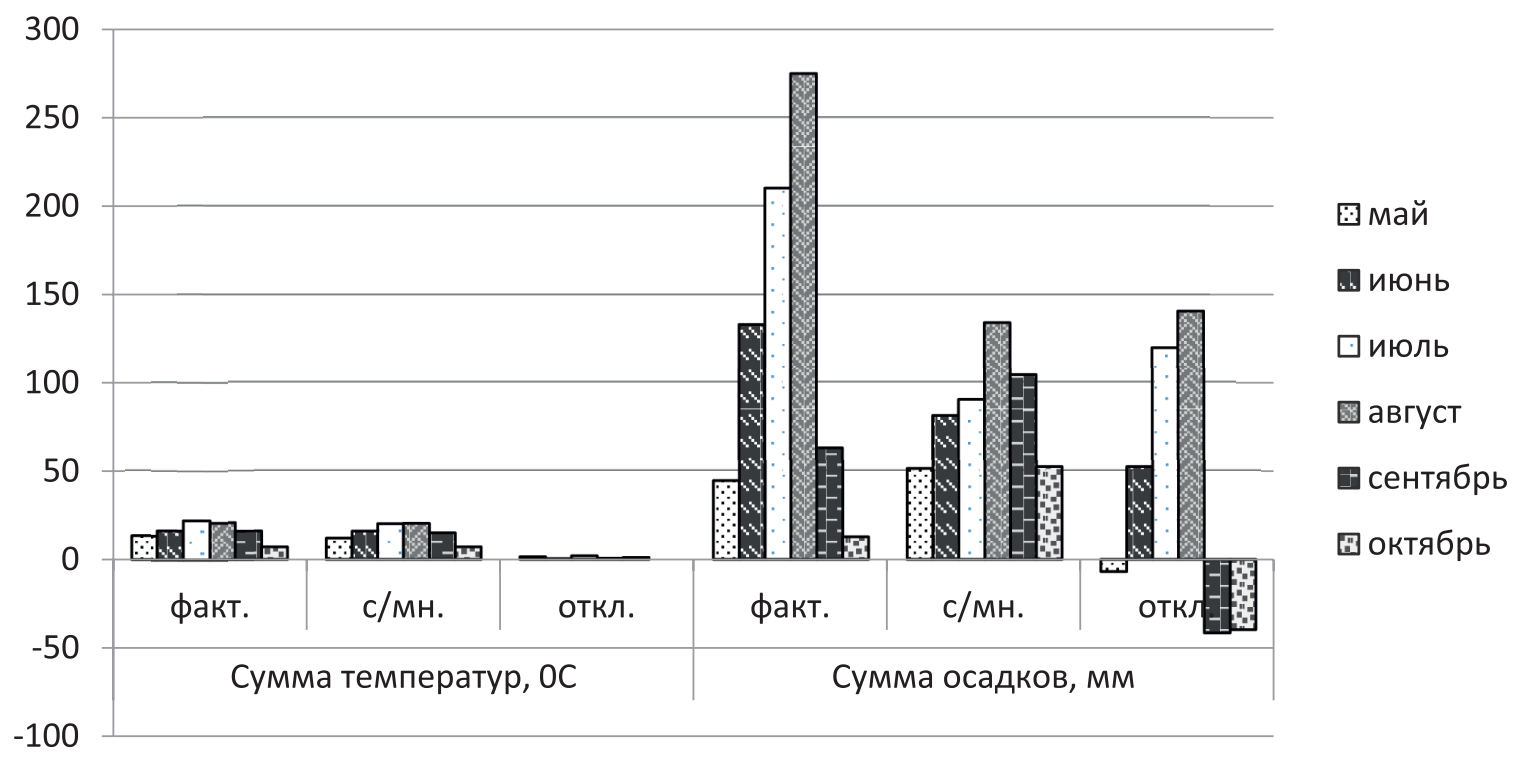

Рисунок 1. Метеорологические условия периода вегетации риса 2017 года (АМС «Тимирязевский») 


\section{Результаты и обсуждение}

В ходе биометрического анализа дигаплоидных линий риса первого поколения выращенных в 2015 г., линия 105, полученная из гибридной комбинации Хазар х Дарий 23, по высоте растений была ниже на 9,4\%, чем гибрид, а по числу зёрен с главной метёлки превышала контрольные растения в 1,7 1,8 раз (табл. 1). Высокая вариация этой линии отмечена по признакам продуктивное кущение (32,1%) и масса зерна с растения (29,3\%).

Таблица 1. Характеристика растений гибридов, и дигаплоидных линий $\left(R_{1}\right)$ по основным хозяйственно-ценным признакам (вегетационный опыт 2015 г.)

\begin{tabular}{|c|c|c|c|c|c|c|c|}
\hline \multirow{2}{*}{$\begin{array}{c}\text { Исходные } \\
\text { гибриды } \\
\text { и номера } \\
\text { линий }\end{array}$} & \multirow{2}{*}{$\begin{array}{c}\text { Высота } \\
\text { растения, } \\
\text { см }\end{array}$} & \multirow[b]{2}{*}{ Кущение } & \multirow[b]{2}{*}{$\begin{array}{c}\text { Кол-во } \\
\text { зерен, шт. }\end{array}$} & \multirow[b]{2}{*}{$\begin{array}{l}\text { Стериль- } \\
\text { ность, \% }\end{array}$} & \multicolumn{2}{|c|}{ Масса зерна, г } & \multirow{2}{*}{$\begin{array}{c}\text { Macca } \\
1000 \text { зе- } \\
\text { рен, г }\end{array}$} \\
\hline & & & & & $\begin{array}{c}\text { с главной } \\
\text { метёлки }\end{array}$ & с растения & \\
\hline \multicolumn{8}{|c|}{ Хазар х Дарий 23} \\
\hline Гибрид & 106,9 & 2,6 & 102,8 & 18,0 & 2,6 & 5,4 & 29,4 \\
\hline 105 & 96,8 & 2,6 & 180,5 & 7,5 & 5,3 & 12,2 & 31,3 \\
\hline \multicolumn{8}{|c|}{ Луговой x Вираж } \\
\hline Гибрид & 72,0 & 1,7 & 117,2 & 15,5 & 2,6 & 3,2 & 26,5 \\
\hline $190-1$ & 82,5 & 4,1 & 124,0 & 17,7 & 3,1 & 10,3 & 29,5 \\
\hline 211 & 86,3 & 3,8 & 120,6 & 10,8 & 3,4 & 11,4 & 30,2 \\
\hline 218 & 78,5 & 11,0 & 138,7 & 5,7 & 3,8 & 27,8 & 28,7 \\
\hline
\end{tabular}

Отобранные дигаплоиды из популяции Луговой х Вираж в первый год показали очень высокую продуктивность растения и продуктивное кущение. Особенно выделилась линия 218, у которой масса зерна с растения составила 27,8 г (табл. 1). Линии характеризовались меньшей изменчивостью признаков по сравненью с гибридом (рис. 2).

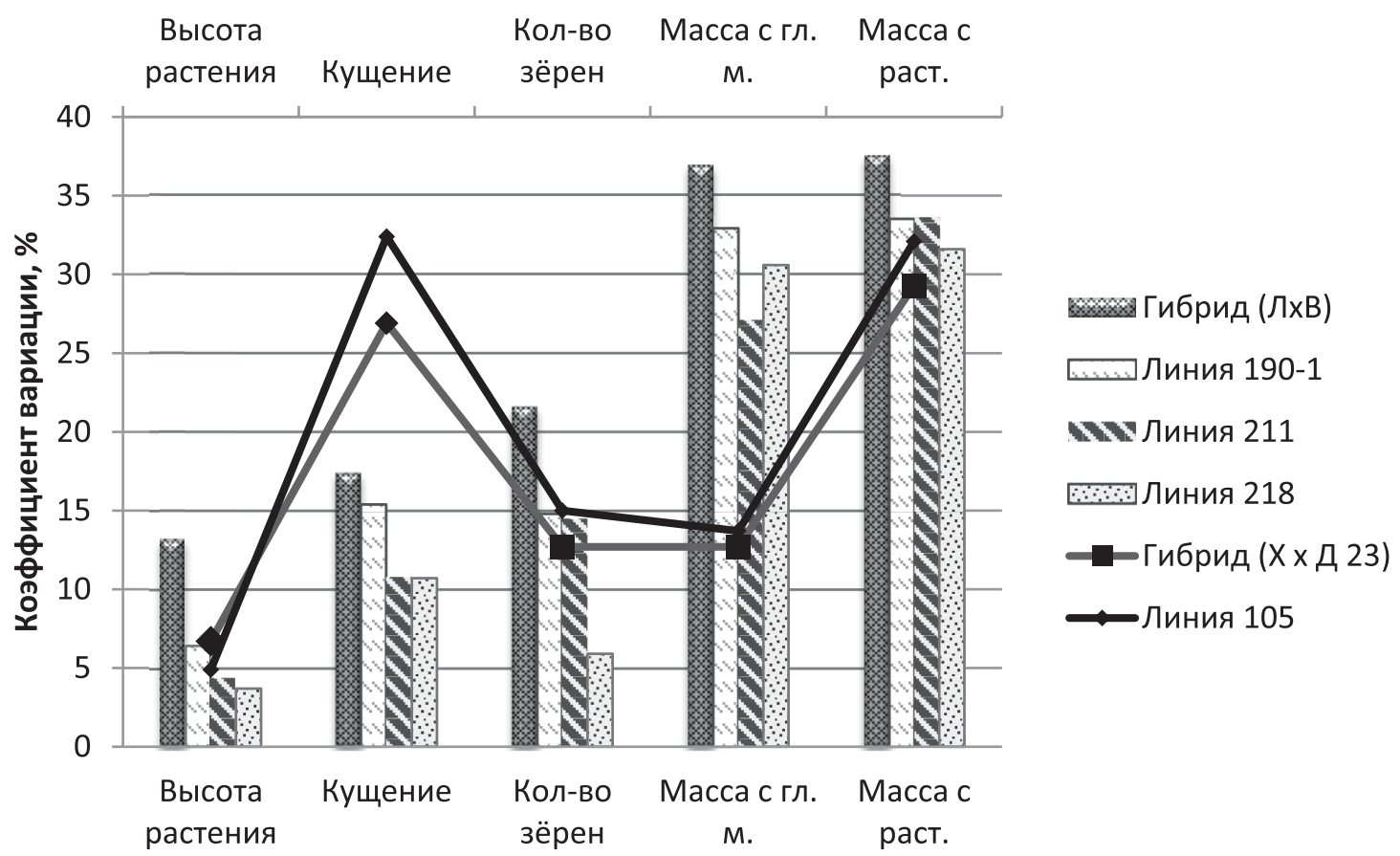

Рисунок 2. Изменчивость количественных признаков дигаплоидных линий и гибридов 2015 г.

При изучении дигаплоидов $\left(\mathrm{R}_{2}-\mathrm{R}_{3}\right)$ в 2016 2017 гг. к группе среднеспелых отнесли линии 105 и 190-1 с периодом вегетации 102 - 103 дня, а линии 211 и 218 - к группе скороспелых с периодом вегетации 98 - 99 дней.
Сравнительная оценка отобранных линий из гибрида Луговой X Вираж показала, что по высоте растений они были низкорослыми $(73,1-76,1$ см) (табл. 2). Линия 105, полученная из популяции Хазар x Дарий 23, относится по этому признаку к среднерослой группе (89,6 см). 
Таблица 2. Характеристика хозяйственно ценных признаков дигаплоидных линий $\mathbf{R}_{2}-\mathbf{R}_{4}$ (полевой опыт 2016 - 2018 гг.)

\begin{tabular}{|c|c|c|c|c|c|}
\hline \multirow{2}{*}{ Показатели } & \multirow{2}{*}{\begin{tabular}{|c|} 
Приморский \\
$29, \mathrm{St}$
\end{tabular}} & \multirow{2}{*}{$\begin{array}{c}\text { Хазар х Дарий } 23 \\
\text { Линия } 105\end{array}$} & \multicolumn{3}{|c|}{ Луговой x Вираж } \\
\hline & & & Линия 190-1 & Линия 211 & Линия 218 \\
\hline \multicolumn{6}{|c|}{$\mathbf{R}_{2}-\mathbf{R}_{3}(2016-2017$ гг.) } \\
\hline Высота растения, см & 73,6 & 89,6 & 76,1 & 73,7 & 73,1 \\
\hline Кущение & 2,5 & 2,6 & 2,5 & 2,4 & 2,6 \\
\hline Количество зерен с метёлки, шт. & 86,9 & 161,8 & 120,9 & 91,7 & 93,4 \\
\hline Стерильность, \% & 10,9 & 9,8 & 11,1 & 11,5 & 11,8 \\
\hline Масса зерна с метёлки, г & 2,3 & 4,6 & 3,1 & 2,4 & 2,7 \\
\hline Масса зерна с растения, г & 4,5 & 8,1 & 5,1 & 3,7 & 5,4 \\
\hline Мacca 1000 зерен, г & 28,8 & 29,7 & 30,4 & 32,4 & 30,7 \\
\hline \multicolumn{6}{|c|}{$\mathbf{R}_{4}(2018$ г.) } \\
\hline Вегетационный период, дн. & 106 & 103 & 102 & 99 & 98 \\
\hline Урожайность, кг/м² & 0,44 & 0,55 & 0,29 & 0,62 & 0,41 \\
\hline
\end{tabular}

По количеству зерен на главной метёлке линия 105 (Хазар х Дарий 23) и линия 190-1 (Луговой х Вираж) превысили стандарт на 85 \% и 39,1 \%, соответственно. Линия 218 отличалась крупностью зерна, масса 1000 зерен составила 32,4 г. Остальные линии по средним значениям других показателей были на уровне со стандартным сортом.

母Линия 105

근 $190-1$ 32,9

Наибольшую урожайность по сравнению со стандартом показали линии $105(0,55$ кг/M²) и $211(0,62$ кг/M²).

За два года изучения в полевых условиях почти по всем основным признакам линия 105, полученная из гибрида Хазар х Дарий 23, показала высокую степень варьирования 20,5 - 23,7 \%. Более стабильные коэффициенты вариации были у линий 190-1 и 218 (Луговой х Вираж) (рис. 3).

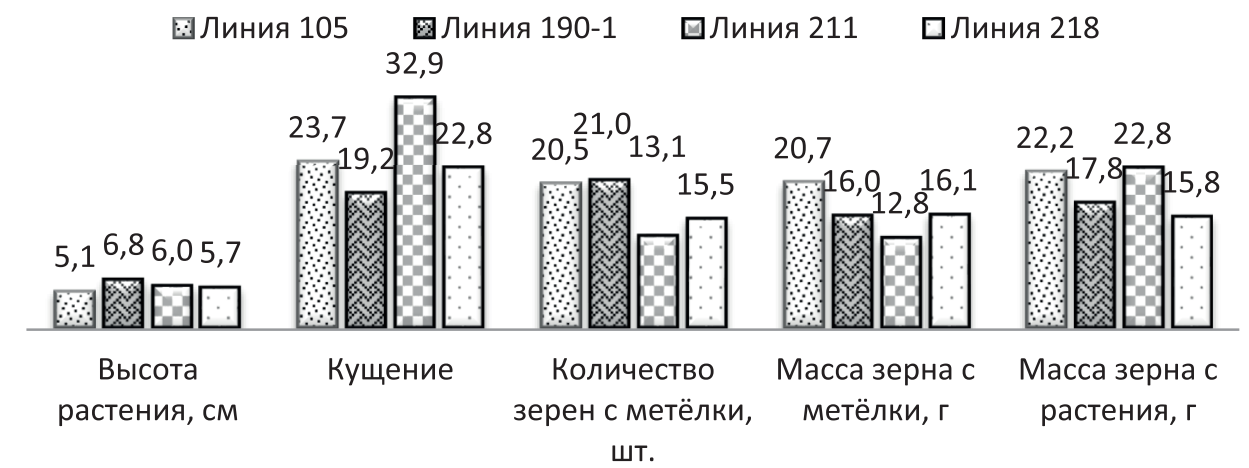

Рисунок 3. Изменчивость количественных признаков дигаплоидных линий и гибридов $\left(\mathbf{R}_{2}-\mathbf{R}_{3}\right)$ за 2016, 2017 гг., \%

\section{Выводы}

В результате проведённого анализа установлено, что дигаплоидные линии показали наибольшую продуктивность растений в первый год изучения $\left(\mathrm{R}_{1}\right)$, чем в последующие годы $\left(\mathrm{R}_{2}-\mathrm{R}_{3}\right)$, но причина, скорее всего в разных условиях выращивания.

1. Линии 190-1 и 218 имели самые низкие коэффициенты изменчивости признаков.
2. По урожайности выделились линии 105 и 211, превышающие стандарт на 24,4 и 40,6 \%.

Таким образом, нами выделены 4 перспективные дигаплоидные линии четвертого поколения $\left(\mathrm{R}_{4}\right)$, полученные из двух разных генотипов: Хазар х Дарий 23 и Луговой $x$ Вираж, которые в дальнейшем будут посеяны в питомнике размножения для дальнейшего размножения и изучения.

\section{ЛИТЕРАТУРА}

1. Гученко, С.С. Оценка дигаплоидных линий риса первого и второго поколений по хозяйственно ценным признакам / С.С. Гученко // Аграрная Россия. - 2018. - № 5. - С. 18 - 23.

2. Доспехов, Б.А. Методика полевого опыта (с основами статистической обработки результатов исследований) / Б.А. Доспехов. - Изд. 5-е, доп. и перераб. Стереотипное изд. - М. : Альянс, 2014. - 351 с.

3. Илюшко, М.В. Создание регенерантных линий методом культуры пыльников in vitro для селекции риса на российском Дальнем Востоке / М.В. Илюшко, М.В. Ромашова // Дальневосточный аграрный вестник. - 2017. - № 4. C. $37-45$. 
4. Сметанин, А.П. Методики опытных работ по селекции, семеноводству, семеноведению и контролю за качеством семян риса / А.П. Сметанин, В.А. Дзюба, А.И. Апрод. - Краснодар, 1972. - 156 с.

5. Федин, М.А. Методика государственного сортоиспытания сельскохозяйственных культур. Вып. 1: Общая часть / М.А. Федин. - М., 1985. - 267 с.

6. Усенбеков, Б.Н. Использование метода культуры пыльников в селекции казахстанских сортов глютинозного риса // Научный журнал КубГАУ. - 2014. - № 101(07). - С. 1 - 12.

7. Чайка, А.К. Состояние и перспективы развития рисоводства на Дальнем Востоке / А.К. Чайка, В.А. Ковалевская // Рисоводство. - 2008. - № 13. - С. 3 - 6.

8. Swapan, K.T. Exploring factors affecting anther culture in rice (Oryza sativa L.) / K.T. Swapan, D. Swain, P.M. Mohapatra, A.M. Prusti and etc. // Journal of Applied Biology \& Biotechnology. - March-April, 2019. - Vol. 7(02). - P. 87 - 92.

9. Mishra, R. In-vitro androgenesis in rice: advantages, constraints and future prospects / R. Mishra, G.J.N. Rao // Rice Science. - 2016. - Vol. 23(2). - P. 57 - 68.

10. Goncharova, Y.K. Nutrient media for double haploid production in anther culture of rice hybrids // Y.K. Goncharova, S.A. Vereshcagina, S.V. Goncharov // Plant Cell Biotechnology and Molecular Biology 20(23\&24). - 2019. - P. 1215 - 1223.

\section{REFERENCES}

1. Guchenko, S.S. Evaluation of dihaploid lines of rice of the first and second generations on agronomic characteristics // Agrarian Russia. - 2018. - № 5. - P. $18-23$.

2. Methodology of Field Trial (with the basis of statistic processing of study results) / B.A. Dospekhov. $-5^{\text {th }}$ issue ad. and appr. - Moscow, 2014. - 351 p.

3. Ilyushko, M.V. Creation of Regenerant Lines by the method of Anther Culture in vitro for Rice Breeding in the Russian Far East / M.V. Ilyushko., M.V. Romashova // Far Eastern Agrarian Herald. - 2017. - № 4. - P. 37 - 45.

4. Experimental methods of breeding, seed production, seed science and quality control of rice seeds / compose. Smetanin, A.P., Aprod, V.A., Dzyuba, A.P. - Krasnodar, 1972. - 155 p.

5. Methods of State Variety Testing of Agricultural Crops. General Part. Vol. 1 / under edit. M. A. Fedina. - M., 1985. 267 p.

6. Usenbekov, B.N. Anther Culture Method in Breeding of Glutinous Rice Varieties in Kazakhstan // Scientific Journal of KubSAU. - 2014. - № 101(07). - P. 1 - 12.

7. Chaika, A.K. State and Prospects of Rice Growing in the Far East / A.K. Chaika, V. A. Kovalevskaya // Rice Growing. 2008. - № 13. - P. 3 - 6.

8. Swapan, K.T. Exploring factors affecting anther culture in rice (Oryza sativa L.) / K.T. Swapan, D. Swain, P.M. Mohapatra, A.M. Prusti and etc. // Journal of Applied Biology \& Biotechnology. - March-April, 2019. - Vol. 7(02). - P. 87 - 92.

9. Mishra, R. In-vitro androgenesis in rice: advantages, constraints and future prospects / R. Mishra, G.J.N. Rao // Rice Science. - 2016. - Vol. 23(2). - P. $57-68$.

10. Goncharova, Y. K. Nutrient media for double haploid production in anther culture of rice hybrids // Y. K Goncharova, S.A. Vereshcagina, S.V. Goncharov // Plant Cell Biotechnology and Molecular Biology 20(23\&24). - 2019. - P. 1215 - 1223.

\section{Светлана Сергеевна Гученко}

И.о. заведующего лаборатории селекции риса, младший научный сотрудник

E-mail: lana_svet8@mail.ru

ФГБНУ «ФНЦ агробиотехнологий Дальнего Востока им. А.К. Чайки» 692539, Приморский край, г. Уссурийск, п. Тимирязевский, ул. Воложенина,30

\section{Svetlana Sergeevna Guchenko}

Acting manager of the Laboratory for rice selection, junior researcher

E-mail: lana_svet8@mail.ru

FSBSI "Federal Scientific Centre of Agrobiotechnology in the Far East named after A.K. Chaika" 30, Volozhenina str., stl. Timiryazevsky, Ussuriysk, Primorsky krai, 692539, Russia 
П.И. Костылев, д-р с.-х. наук,

А.В. Аксенов,

Е.В. Краснова, канд. С.-Х. наук г. Зерноград, Россия

E.В. Дубина, д-р биол. наук г. Краснодар, Россия

\section{СРАВНИТЕЛЬНАЯ ОЦЕНКА УРОЖАЙНОСТИ СУХОДОЛЬНЫХ ОБРАЗЦОВ РИСА ПРИ РАЗНЫХ РЕЖИМАХ ОРОШЕНИЯ}

Представлены результаты изучения сортов и образцов суходольного риса в лаборатории селекции и семеноводства риса АНЦ «Донской» на базе ОП «Пролетарское» Ростовской области. Цель исследований - изучить коллекционные, гибридные и селекционные образцы риса на устойчивость к длительному пересыханию почвы и воздушной засухе, отбор засухоустойчивых форм для создания сортов нового типа. Материалы исследования: 65 образцов и сортов риса различного происхождения, в частности, коллекционные образцы риса ВИР им. Н.И. Вавилова: Золотые всходы (Россия), Маловодотребовательный (Узбекистан), Ан-Юн-Хо, Дин-Сян, Контро, Хун-Мо, Чан-Чунь-Ман (Китай); линии от их скрещивания в предыдущие годы с сортами Боярин, Командор, Кубояр, Раздольный; засухоустойчивые линии из краснодарской гибридной популяции, а также сорта: Акустик, Боярин, Вирасан, Волгоградский, Контакт, Сталинградский, Суходол, Южанин. Образцы выращивали на засушливом и обычном фонах орошения. Установлено, что растения в обычных и засушливых условиях формировались по-разному, и урожайность зерна при периодическом орошении составила в среднем 67,9 \% к норме. Выявлены сорта Контакт, Золотые всходы, Маловодотребовательный, линии ЗУЛК 6 и ЗУЛК 15, соотношение опыта к контролю (О/К) у которых составило от 106,9 до 138,0 \%. Отмечено удлинение времени до цветения у всех образцов, но в различной степени, от 4,9 до 25,7 \%. Максимальную урожайность в засушливых условиях сформировали сорта Боярин (4,43 т/га), Контакт (4,53 т/га), Золотые всходы (4,60 т/га) и Суходол (4,60 т/га).

Ключевые слова: рис, сорт, источник, суходол, засухоустойчивость, периодический полив, урожайность.

\section{COMPARATIVE ASSESSMENT OF UPLAND RICE VARIETIES UNDER DIFFERENT IRRIGATION REGIMES}

The results of the study of varieties and samples of dry land rice in the laboratory of selection and seed production of rice of the ARC "Donskoy" on the basis of the OP "Proletarskoe" of the Rostov region. The purpose of the research is to study collection, hybrid and breeding rice samples for resistance to prolonged drying out of the soil and air drought, selection of drought-resistant forms for creating varieties of a new type. Research materials: 65 samples and varieties of rice of various origins, in particular, collection samples of rice VIR im. N.I. Vavilov: Golden shoots (Russia), Low water demanding (Uzbekistan), An-Yun-Ho, Din-Xiang, Kontro, Khun-Mo, Chan-Chun-Man (China); lines from their crossing in previous years with varieties Boyarin, Komandor, Kuboyar, Razdolny; drought-resistant lines from the Krasnodar hybrid population, as well as varieties: Akustik, Boyarin, Virasan, Volgogradskiy, Kontakt, Stalingradskiy, Sukhodol, Yuzhanin. The samples were grown in dry and normal irrigation backgrounds. It was found that plants under normal and arid conditions formed differently, and the grain yield under periodic irrigation averaged $67.9 \%$ of the norm. The varieties Kontakt, Zolotye vshody, Malovodrebovatelny, lines ZULK 6 and ZULK 15 were identified, the ratio of experience to control (O/C) in which ranged from 106.9 to $138.0 \%$. Elongation of time to flowering was noted in all samples, but to varying degrees, from 4.9 to $25.7 \%$. The maximum yield in dry conditions was formed by the varieties Boyarin (4.43 t/ha), Kontact (4.53 t/ha), Zolotye vshody (4.60 t/ha) and Sukhodol (4.60 t/ha).

Key words: rice, variety, source, dry land, drought resistance, periodic irrigation, yield.

\section{Введение}

Рис является одной из основных продовольственных культур в мире. Повышение его продуктивности является сложной задачей на фоне возникновения различных абиотических стрессов, а также возросшей частоты экстремальных погодных условий [5]. Среди многочисленных абиотических стрессов засуха или дефицит воды считаются наиболее важными ограничениями в производстве риса во многих районах его выращивания [10].
Засушливые условия могут повлиять на растения на любой стадии роста, но засушливый стресс на репродуктивной стадии непосредственно приводит к потере урожая на $24-84$ \% [7]. Понимание механизма засухоустойчивости риса, идентификация устойчивого генофонда риса, разработка новых стратегий и методов отбора, идентификация локусов количественных признаков и генов предоставляют большие возможности для повышения засухоустойчивости риса. 
Для сельскохозяйственных культур засухоустойчивость - это не только способность выживать или расти в условиях дефицита воды, но и минимальная потеря урожая в результате стресса. Засухоустойчивость риса можно определить как способность к выживанию и продуктивность в условиях засухи [4]. Засухоустойчивость - это количественный признак, который часто обозначается относительными значениями (значениями в условиях засушливого стресса относительно значений в нормальных условиях роста) различных признаков.

Устойчивость риса к засухе определяется четырьмя механизмами: уход от засухи, предотвращение засухи, устойчивость к засухе и восстановление после засухи [2, 3, 4, 9].

Уход от засухи (УЗ) относится к избеганию стресса с помощью короткого жизненного цикла или пластичности развития. В сельскохозяйственном производстве УЗ означает преодоление сезонной или климатической засухи путем корректировки сроков посева или использования раннеспелых сортов.

Предотвращение засухи характеризуется главным образом способностью растений поддерживать высокий водный статус в условиях засухи за счет увеличения поглощения воды и снижения потерь воды. Например, это может быть достигнуто за счет развития густой и глубокой корневой системы для использования воды или за счет закрытия устьиц, свертывания листьев или непроницаемой кутикулы листьев для уменьшения транспирации.

Засухоустойчивость (ЗУ) определяется как способность растительных клеток поддерживать свою функцию в условиях дефицита воды путем уменьшения вызванного стрессом повреждения с помощью механизмов регуляции экспрессии генов и метаболических путей. ЗУ часто ассоциируется с накоплением в растительных клетках молекул, связанных с осмотическим регулированием для поддержания тургора (таких как пролин).

Восстановление после засухи относится к восстановительной способности растения после периода сильного засушливого стресса, который вызывает полную потерю тургора и высыхание листьев.

Засухоустойчивость - это сложный признак, связанный с изменениями на морфологическом, физиологическом, биохимическом и молекулярном уровнях. Важно определить основные критерии или показатели для оценки засухоустойчивости различных культур. Показатели засухоустойчивости риса можно разделить на три категории:

1) индексы, основными критериями которых являются морфологические и физиологические признаки;

2) индексы, включающие в себя несколько физиологических признаков, связанных с осмотической регулировкой, содержание абсцизовой кислоты и реакция на нее, а также защита от окислительного стресса;

3) составные индексы, включающие признаки, связанные с биологической или экономической урожайностью в условиях засушливого стресса.
Хотя комплексную индексную систему трудно применять для выявления механизма засухоустойчивости, некоторые составные индексы (особенно признаки, связанные с урожайностью) предпочтительны и эффективны для селекции на засухоустойчивость [8].

\section{Цель исследований}

Изучить коллекционные, гибридные и селекционные образцы риса на устойчивость к длительному пересыханию почвы и воздушной засухе, отобрать засухоустойчивые формы для создания сортов нового типа.

\section{Материалы и методы}

Изучали 65 образцов и сортов риса различного происхождения, в частности, коллекционные образцы риса ВИР им. Н.И. Вавилова: Золотые всходы (Россия), Маловодотребовательный (Узбекистан), Ан-Юн-Хо, Дин-Сян, Контро, Хун-Мо, Чан-Чунь-Ман (Китай); линии от их скрещивания в предыдущие годы с сортами Боярин, Командор, Кубояр, Раздольный; засухоустойчивые линии из краснодарской гибридной популяции (ЗУЛК), предоставленной в 2016 году Гончаровой Ю.К.; а также для сравнения сорта: Акустик, Боярин, Вирасан, Волгоградский, Контакт, Сталинградский, Суходол, Южанин.

Исследования проводили в 2019-2020 гг. в лаборатории селекции и семеноводства риса АНЦ «Донской» на базе ОП «Пролетарское» Ростовской области. Образцы высевали на двух фонах: засушливый и нормальный (затопляемый). Для выращивания суходольного риса был выделен специальный чек с периодическим орошением. Рис выращивали на делянках площадью 10 м² в трехкратной повторности с нормой высева 500 семян на 1 м² для испытания в условиях засухи и оценки продуктивности и толерантности к нехватке воды образцов риса. Полив осуществляли напуском воды после посева - 10 мая слоем 10 см и в период вегетации - 12 июня (5 см), 28 июля (8 см) и 17 августа (10 см) при просушивании почвы до состояния растрескивания корки. Степень засухоустойчивости определяли по соотношению величины признака в опыте к таковой на контроле (O/K). Математическую обработку данных делали с помощью программ Excel и Statistica 8.

В 2019 году наблюдалось пониженное количество осадков в июне и августе и высокая среднемесячная температура с апреля по сентябрь. Погодные условия 2020 года характеризовались обильными дождями в мае и июне; пониженным количеством осадков в апреле, июле и августе и их отсутствием в сентябре, т.е. высокой степенью засушливости во второй половине вегетации риса. Температурный режим апреля и мая был ниже нормы, а летом и в сентябре превышал ее на 2,3 - 4,3 ${ }^{\circ} \mathrm{C}$.

\section{Результаты и обсуждение}

В 2019 году были изучены коллекционные образцы риса в условиях периодического орошения, выделены формы с повышенной засухоустойчивостью: Золотые всходы (Россия), Маловодотребовательный 
(Узбекистан), Ан-Юн-Хо, Дин-Сян, Контро, Хун-Мо, Чан-Чунь-Ман (Китай) и др. Выявлены абсолютные и относительные различия в проявлении ряда количественных признаков у семи суходольных образцов, особенно выделились Хун-Мо, Дин-Сян, ЧанЧунь-Ман. Максимальный интегральный показатель устойчивости оказался у образца Хун-Мо (69,1%), а минимальный - у Ан-Юн-Хо (53,6 \%). Наибольшее соотношение величины признака в засушливых и нормальных условиях в среднем по всем сортам было по массе 1000 зерен (97,1\%), затем в порядке убывания расположились высота растения (81,7 \%), длина метелки (76,8 \%), урожайность (63,4 \%), масса зерна с метелки (42,3 \%), количество выполненных зерен на метелке $(38,1 \%)$ и количество пустых колосков на метелке (21,6 \%). Таким образом, в наименьшей степени снижается масса зерновки, а в наибольшей - количество колосков и зерен в метелке [1]

В 2020 году, несмотря на жесткие условия, большинство изучаемых образцов риса сформировали зерно. Тем не менее, растения в нормальных и засушливых условиях формировались по-разному, и вторые значительно уступали первым по урожайности, которая в среднем составила 67,9 \% к норме (табл.).

Таблица. Урожайность и вегетационный период риса при засухе и в нормальных условиях, Пролетарск, Ростовская область, 2020 г.

\begin{tabular}{|c|c|c|c|c|c|c|c|c|}
\hline \multirow[t]{2}{*}{$\begin{array}{l}\text { № } \\
\text { пா. }\end{array}$} & \multirow[t]{2}{*}{$\begin{array}{c}\text { № } \\
\text { образца }\end{array}$} & \multirow[t]{2}{*}{ Название сорта, образца } & \multicolumn{3}{|c|}{ Урожайность, т/га } & \multicolumn{3}{|c|}{$\begin{array}{c}\text { Продолжительность } \\
\text { периода «залив } \\
\text { водой - цветение» }\end{array}$} \\
\hline & & & Контроль & Опыт & $\mathrm{O} / \mathrm{K}, \%$ & Контроль & Опыт & $\mathrm{O} / \mathrm{K}, \%$ \\
\hline 1 & & Акустик & 6,67 & 3,77 & 56,5 & 92 & 106 & 114,9 \\
\hline 2 & & Боярин & 5,29 & 4,43 & 83,7 & 81 & 93 & 115,3 \\
\hline 3 & & Вирасан & 4,27 & 4,10 & 95,9 & 81 & 99 & 122,7 \\
\hline 4 & 8154 & Волгоградский & 4,08 & 3,53 & 86,6 & 74 & 93 & 125,7 \\
\hline 5 & & Контакт & 4,20 & 4,53 & 108,0 & 80 & 93 & 115,8 \\
\hline 6 & 8208 & Сталинградский & 5,18 & 4,17 & 80,5 & 82 & 93 & 113,4 \\
\hline 7 & 8062 & Суходол & 6,35 & 4,60 & 72,4 & 90 & 108 & 119,6 \\
\hline 8 & & Южанин & 5,29 & 3,97 & 74,9 & 89 & 104 & 117,2 \\
\hline 9 & 552 & Ан-Юн-Хо,Китай & 4,04 & 4,03 & 99,9 & 80 & 90 & 112,1 \\
\hline 10 & 548 & Дин-Сян, Китай & 3,92 & 3,47 & 88,4 & 76 & 88 & 115,8 \\
\hline 11 & 546 & Золотые всходы & 3,33 & 4,60 & 138,0 & 73 & 86 & 117,3 \\
\hline 12 & 547 & Контро, Китай & 4,27 & 3,70 & 86,6 & 78 & 90 & 116,3 \\
\hline 13 & 553 & Маловодотребовательный, Узбекистан & 3,06 & 4,13 & 135,1 & 77 & 87 & 112,5 \\
\hline 14 & 550 & Хун-Мо, Китай & 3,65 & 3,07 & 84,1 & 78 & 91 & 117,1 \\
\hline 15 & 551 & Чан-Чунь-Ман, Китай & 4,59 & 3,97 & 86,5 & 79 & 88 & 110,9 \\
\hline 16 & 7949 & Дин Сян х Боярин & 4,12 & 2,97 & 72,0 & 88 & 97 & 110,2 \\
\hline 17 & 7950 & Дин Сян х Кубояр & 4,47 & 3,13 & 70,1 & 88 & 97 & 110,2 \\
\hline 18 & 7953 & Командор х Ан-Юн-Хо & 6,04 & 3,30 & 54,6 & 93 & 104 & 111,8 \\
\hline 19 & 7954 & Командор х Золотые всходы & 5,22 & 2,70 & 51,8 & 87 & 97 & 111,5 \\
\hline 20 & 7952 & Командор х Маловодотребовательный & 4,94 & 4,20 & 85,0 & 85 & 98 & 115,7 \\
\hline 21 & 7955 & Командор х Хун-Мо & 5,22 & 2,43 & 46,7 & 89 & 97 & 109,4 \\
\hline 22 & 7970 & Командор х Чан-Чунь-Ман & 5,61 & 4,30 & 76,7 & 89 & 93 & 104,9 \\
\hline 23 & 7969 & Командор х Чан-Чунь-Ман & 4,27 & 3,60 & 84,2 & 83 & 95 & 114,5 \\
\hline 24 & 7968 & Командор х Чан-Чунь-Ман & 4,27 & 3,87 & 90,5 & 83 & 93 & 112,0 \\
\hline 25 & 7958 & Контро х Боярин & 4,94 & 2,53 & 51,3 & 84 & 93 & 110,7 \\
\hline 26 & 7844 & Раздольный x Суходольный & 2,86 & 2,00 & 69,9 & 88 & 97 & 110,6 \\
\hline 27 & 6284 & Скомс белый x Кубань 3 & 3,33 & 2,87 & 86,0 & 90 & 106 & 117,4 \\
\hline 28 & 7791 & Скомс белый x Кубань 3 & 3,61 & 1,60 & 44,3 & 93 & 108 & 116,9 \\
\hline 29 & 7793 & Скомс белый x Кубань 3 & 3,33 & 1,90 & 57,0 & 93 & 108 & 116,2 \\
\hline 30 & 7967 & Скомс белый x Кубань 3 & 4,31 & 3,47 & 80,4 & 91 & 107 & 117,6 \\
\hline 31 & 6465 & Суходол x Боярин & 5,76 & 2,40 & 41,6 & 88 & 103 & 117,0 \\
\hline 32 & 7970 & Суходол х Кубояр & 6,00 & 3,43 & 57,2 & 87 & 98 & 113,0 \\
\hline 33 & Д5703 & Чан-Чунь-Ман x Боярин & 6,27 & 3,17 & 50,5 & 88 & 104 & 118,6 \\
\hline 34 & 7976 & Чан-Чунь-Ман x Боярин & 5,65 & 3,60 & 63,8 & 89 & 109 & 122,5 \\
\hline 35 & 7975 & Чан-Чунь-Ман x Боярин & 5,22 & 3,17 & 60,7 & 89 & 108 & 121,0 \\
\hline
\end{tabular}


Продолжение таблицы

\begin{tabular}{|c|c|c|c|c|c|c|c|c|}
\hline \multirow[t]{2}{*}{$\begin{array}{l}\text { № } \\
\text { пா. }\end{array}$} & \multirow[t]{2}{*}{$\begin{array}{c}\text { № } \\
\text { образца }\end{array}$} & \multirow[t]{2}{*}{ Название сорта, образца } & \multicolumn{3}{|c|}{ Урожайность, т/га } & \multicolumn{3}{|c|}{$\begin{array}{c}\text { Продолжительность } \\
\text { периода «залив } \\
\text { водой - цветение» }\end{array}$} \\
\hline & & & Контроль & Опыт & $\mathrm{O} / \mathrm{K}, \%$ & Контроль & Опыт & $\mathrm{O} / \mathrm{K}, \%$ \\
\hline 36 & 7974 & Чан-Чунь-Ман х Боярин & 6,78 & 3,07 & 45,2 & 89 & 109 & 122,5 \\
\hline 37 & 7973 & Чан-Чунь-Ман х Боярин & 5,73 & 3,20 & 55,9 & 92 & 108 & 117,8 \\
\hline 38 & 7972 & Чан-Чунь-Ман x Боярин & 7,02 & 2,73 & 38,9 & 92 & 106 & 115,6 \\
\hline 39 & 7972 & Чан-Чунь-Ман х Кубояр & 4,90 & 2,77 & 56,4 & 93 & 108 & 115,4 \\
\hline 40 & 6472 & Чан-Чунь-Ман х Раздольный & 6,16 & 2,87 & 46,6 & 92 & 109 & 118,4 \\
\hline 41 & 7979 & Чан-Чунь-Ман х Раздольный & 4,75 & 3,60 & 75,9 & 90 & 100 & 111,5 \\
\hline 42 & 7977 & Чан-Чунь-Ман х Раздольный & 4,63 & 3,50 & 75,6 & 87 & 100 & 115,3 \\
\hline 43 & 7966 & Чан-Чунь-Ман х Южанин & 4,20 & 4,03 & 96,1 & 86 & 102 & 118,2 \\
\hline 44 & 7965 & Чан-Чунь-Ман x Южанин & 3,69 & 2,97 & 80,5 & 83 & 99 & 119,3 \\
\hline 45 & 7926 & (Чан-Чунь-Ман х Боярин) х Кубояр & 5,33 & 3,90 & 73,1 & 88 & 97 & 110,2 \\
\hline 46 & 7927 & (Чан-Чунь-Ман х Боярин) х Кубояр & 4,90 & 3,87 & 78,9 & 92 & 102 & 110,5 \\
\hline 47 & 7928 & (Чан-Чунь-Ман х Боярин) х Кубояр & 5,73 & 3,57 & 62,3 & 91 & 98 & 108,5 \\
\hline 48 & 7981 & (Суходол x Боярин) х Боярин & 4,63 & 3,97 & 85,7 & 81 & 93 & 114,8 \\
\hline 49 & 7978 & (Lampo x Вираж) x Боярин & 2,82 & 1,5 & 53,1 & 92 & 107 & 116,3 \\
\hline 50 & 8032 & Волгоградский x Магнат & 6,08 & 2,50 & 41,1 & 93 & 108 & 116,1 \\
\hline 51 & 7851 & ЗУЛК 1 & 2,82 & 2,17 & 76,7 & 93 & 105 & 112,9 \\
\hline 52 & 7852 & ЗУЛК 2 & 4,39 & 4,33 & 98,7 & 81 & 93 & 115,3 \\
\hline 53 & 7853 & ЗУЛК 3 & 5,53 & 3,20 & 57,9 & 82 & 96 & 117,1 \\
\hline 54 & 7854 & ЗУЛК 4 & 4,55 & 1,33 & 29,3 & 93 & 110 & 119,1 \\
\hline 55 & 7857 & ЗУЛК 5 & 3,41 & 3,20 & 93,8 & 93 & 104 & 111,8 \\
\hline 56 & 7858 & ЗУЛК 6 (тип Боярин) & 3,65 & 3,90 & 106,9 & 84 & 93 & 110,7 \\
\hline 57 & 6551 & ЗУЛК 7 & 5,80 & 1,80 & 31,0 & 96 & 112 & 117,1 \\
\hline 58 & 7774 & ЗУЛК 8 & 6,24 & 4,20 & 67,4 & 92 & 108 & 117,0 \\
\hline 59 & 7776 & ЗУЛК 9 & 5,53 & 2,83 & 51,2 & 83 & 99 & 119,3 \\
\hline 60 & 7856 & ЗУЛК 10 & 3,84 & 3,27 & 85,0 & 83 & 95 & 114,5 \\
\hline 61 & 7971 & ЗУЛК 11 & 4,86 & 3,03 & 62,4 & 91 & 106 & 116,1 \\
\hline 62 & 7826 & ЗУЛК 12 (остистый) & 7,41 & 1,33 & 18,0 & 100 & 103 & 103,0 \\
\hline 63 & 7775 & ЗУЛК 13 (черное зерно) & 4,86 & 1,90 & 39,1 & 102 & 111 & 109,2 \\
\hline 64 & 7855 & ЗУЛК 14 (черное зерно) & 3,80 & 2,23 & 58,7 & 85 & 90 & 106,3 \\
\hline 65 & 8224 & ЗУЛК 15 (черное зерно) & 2,43 & 2,97 & 122,0 & 85 & 95 & 111,8 \\
\hline & & Средние & 4,77 & 3,24 & 67,9 & 87 & 100 & 114,7 \\
\hline
\end{tabular}

Однако некоторые сорта и образцы сформировали в условиях недостаточного увлажнения даже более высокую урожайность, чем при постоянном затоплении водой. К ним относятся Контакт, Золотые всходы, Маловодотребовательный, ЗУЛК 6 и ЗУЛК 15 , соотношение опыта к контролю (О/К) у которых составило от 106,9 до 138,0 \%. Это связано со скороспелостью и чувствительностью к затоплению. Часть образцов сформировали примерно одинаковую урожайность зерна на обоих вариантах опыта, О/К - от 86,5 до 99,9 \%. Это маньчжурские коллекционные суходольные образцы: Ан-Юн-Хо, Дин-Сян, Контро, Чан-Чунь-Ман, Чан-Чунь-Ман х Южанин (7966), Командор х Чан-Чунь-Ман (7968), скороспелые сорта Вирасан и Волгоградский, краснодарские гибридные линии ЗУЛК 2 и ЗУЛК 5.

Наименьшее соотношение О/К отмечено у образцов ЗУЛК 12 (18,0 \%), ЗУЛК 4 (29,3 \%) и ЗУЛК 7
(31,0 \%). Это связано со значительной задержкой времени цветения и созревания, вызванной засухой, и низкой фертильностью колосков из-за сильных суховеев.

Стресс от засухи, возникающий в начале репродуктивной стадии, обычно приводит к задержке цветения. Это происходит главным образом изза замедленного удлинения метелки и ее тканей. Этот признак может эффективно способствовать предотвращению влияния засухи, если период дефицита воды короткий, так как удлинение метелки возобновляется после снятия короткого периода стресса. Однако если цветение задерживается более чем на несколько дней, то обычно происходят серьезные потери урожая. Чем больше задержка цветения, тем больше стерильность колосков и снижение урожайности и индекса урожая из-за засухи. Таким образом, повышение засухо- 
устойчивости может включать отбор растений, у которых из-за засухи наблюдается незначительная задержка цветения или она вообще отсутствует [6].

Задержка времени цветения произошла у всех изученных образцов, но в различной степени. У пяти образцов (№ 21, 22, 47, 63, 64 в таблице) она не превышала $10 \%$, у остальных составляла от 10,2 до 25,7 \%. Наибольшая задержка развития наблюдалась у скороспелых сортов Вирасан и Волгоградский, а также у трех линий из гибридной комбинации ЧанЧунь-Ман х Боярин (7974, 7975 и 7975).

Корреляция урожайности при засухе с урожайностью при затоплении отсутствовала $(r=0,05 \pm 0,01)$, с их соотношением О/К была средней положительной ( $r=0,70 \pm 0,01)$, а с продолжительностью периода вегетации от прорастания до цветения на контроле и в опыте - средней отрицательной $(r=-0,56 \pm 0,01)$, $(r=-0,52 \pm 0,01)$, соответственно. Поэтому скороспелые формы при выращивании с периодическим поливом имеют преимущество перед средне- и позднеспелыми.

Максимальную урожайность в засушливых условиях сформировали сорта Боярин (4,43 т/га), Контакт (4,53 т/га), Золотые всходы (4,60 т/га) и Суходол (4,60 т/га). При этом первые три получили преимущество благодаря скороспелости, а сорт Суходол хотя и потерял из-за среднеспелости и задержки развития 27,6 \% урожая, но компенсировал это более высокой урожайностью на контроле, составившей 6,35 т/га. Таким образом, механизмы формирования урожая зерна в условиях недостаточного увлажнения могут быть различными.

В результате проведенной работы из изученного набора сортов и образцов выделили формы, устойчивые к недостаточному увлажнению, которые можно выращивать в нерисоводческих хозяйствах при периодическом орошении.

\section{Выводы}

1. Установлено, что механизмы формирования урожая зерна в условиях недостаточного увлажнения могут быть различными.

2. Наибольшую урожайность в засушливых условиях сформировали сорта Боярин (4,43 т/га), Контакт (4,53 т/га), Золотые всходы (4,60 т/га) и Суходол (4,60 т/га). При этом первые три получили преимущество благодаря скороспелости, а сорт Суходол хотя и потерял из-за среднеспелости и задержки развития 27,6 \% урожая, но имел более высокий потенциал урожайности, который на контроле составил 6,35 т/га.

3. В процессе проведенной работы из изученного набора сортов и образцов были выделены формы, устойчивые к недостаточному увлажнению, которые можно выращивать в обычных, не рисоводческих хозяйствах при периодическом орошении.

\section{ЛИТЕРАТУРА}

1. Костылев, П.И. Селекционная работа по маловодотребовательному рису в АНЦ «Донской» / П.И. Костылев, Е.В. Краснова, А.В. Аксенов // Зерновое хозяйство России. - 2020. - № 1(67). - С. 54 - 58. DOI: 10.31367/2079-87252020-67-1-54-58

2. Fukai, S. Development of drought resistant cultivars using physiomorphological traits in rice / S. Fukai, M. Cooper // Field Crop Res. - 1995. - 40(2). - P. 67 - 86.

3. Lawlor, D.W. Genetic engineering to improve plant performance under drought: physiological evaluation of achievements, limitations, and possibilities / D.W. Lawlor // J. Exp Bot. - 2013. - 64(1). - P. 83 - 108.

4. Luo L.J. Breeding for water-saving and drought resistance rice (WDR) in China / L.J. Luo // J. Exp. Bot. - 2010. 61(13). - P. $3509-3517$.

5. Mittler, R. Genetic engineering for modern agriculture: challenges and perspectives / R. Mittler, E. Blumwald // Annu Rev Plant Biol. - 2010. - 61. - P. 443 - 462.

6. Pantuwan, G. Yield response of rice (Oryza sativa L.) genotypes to drought under rainfed lowlands: 2 . Selection of drought resistant genotypes / G. Pantuwan, S. Fukai, M. Cooper, S. Rajatasereekul, J.C. O'Toole // Field Crops Research. 2002. - 73. - P. $169-180$.

7. Venuprasad, R. Response to direct selection for grain yield under drought stress in rice / R. Venuprasad, H. Lafitte, G. Atlin // Crop Sci. - 2007. - 47(1). - P. $285-293$.

8. You, J. Genetic Improvement of Drought Resistance in Rice // in book "Genetic Manipulation in Plants for Mitigation of Climate Change" / J. You, L. Xiong // P.K. Jaiwal et al. (eds.), Springer, India. - 2015. - P. 73 - 76. DOI 10.1007/978-81322-2662-8_1

9. Yue, B. Genetic basis of drought resistance at reproductive stage in rice: separation of drought tolerance from drought avoidance / B. Yue, W. Xue, L. Xiong, X. Yu, L. Luo, K. Cui, D. Jin, Y. Xing, Q. Zhang // Genetics. - 2006. - 172(2). P. $1213-1228$.

10. Zhang Q. Strategies for developing Green Super Rice / Q. Zhang // Proc. Natl. Acad. Sci. USA. - 2007. - 104(42). P. $16402-16409$.

\section{REFERENCES}

1. Kostylev, P.I. Breeding work on low-water demanding rice in the ARC "Donskoy" / P.I. Kostylev, E.V. Krasnova, A.V. Aksenov // Grain economy of Russia. - 2020. - № 1(67). - P. 54 - 58. DOI: 10.31367 / 2079-8725-2020-67-1-54-58/

2. Fukai, S. Development of drought resistant cultivars using physiomorphological traits in rice / S. Fukai, M. Cooper // Field Crop Res. - 1995. - 40(2). - P. 67 - 86. 
3. Lawlor, D.W. Genetic engineering to improve plant performance under drought: physiological evaluation of achievements, limitations, and possibilities / D.W. Lawlor // J. Exp Bot. - 2013. - 64(1). - P. 83 - 108.

4. Luo L.J. Breeding for water-saving and drought resistance rice (WDR) in China / L.J. Luo // J. Exp. Bot. - 2010. 61(13). - P. $3509-3517$.

5. Mittler, R. Genetic engineering for modern agriculture: challenges and perspectives / R. Mittler, E. Blumwald // Annu Rev Plant Biol. - 2010. - 61. - P. 443 - 462.

6. Pantuwan, G. Yield response of rice (Oryza sativa L.) genotypes to drought under rainfed lowlands: 2 . Selection of drought resistant genotypes / G. Pantuwan, S. Fukai, M. Cooper, S. Rajatasereekul, J.C. O'Toole // Field Crops Research. 2002. - 73. - P. $169-180$.

7. Venuprasad, R. Response to direct selection for grain yield under drought stress in rice / R. Venuprasad, H. Lafitte, G. Atlin // Crop Sci. - 2007. - 47(1). - P. 285 - 293.

8. You, J. Genetic Improvement of Drought Resistance in Rice // in book "Genetic Manipulation in Plants for Mitigation of Climate Change" / J. You, L. Xiong // P.K. Jaiwal et al. (eds.), Springer, India. - 2015. - P. 73 - 76. DOI 10.1007/978-81322-2662-8_1.

9. Yue, B. Genetic basis of drought resistance at reproductive stage in rice: separation of drought tolerance from drought avoidance / B. Yue, W. Xue, L. Xiong, X. Yu, L. Luo, K. Cui, D. Jin, Y. Xing, Q. Zhang // Genetics. - 2006. - 172(2). P. $1213-1228$.

10. Zhang Q. Strategies for developing Green Super Rice / Q. Zhang // Proc. Natl. Acad. Sci. USA. - 2007. - 104(42). P. 16402-16409.

\section{Павел Иванович Костылев}

Главный научный сотрудник лаборатории селекции и семеноводства риса

E-mail: p-kostylev@mail.ru

\section{Елена Викторовна Краснова}

Ведущий научный сотрудник лаборатории селекции и семеноводства риса

\section{Александр Владимирович Аксенов}

Агроном лаборатории селекции

и семеноводства риса

Bce: ФГБНУ «АНЦ «Донской», 347740, Россия, Зерноград, Научный гор., 3

\section{Елена Викторовна Дубина}

Заведующий лабораторией информационных, цифровых и биотехнологий

E-mail: lenakrug1@rambler.ru ФГБНУ «ФНЦ риса»

350921, Россия, Краснодар, Белозерный, 3

\section{Pavel I. Kostylev}

Chief researcher of the laboratory

of breeding and seed production of rice

E-mail: p-kostylev@mail.ru

\section{Elena V. Krasnova}

Leading researcher of the laboratory

of breeding and seed production of rice

\section{Alexander V. Aksenov}

Agronomist of the laboratory of breeding

and seed production of rice

All: FSBSI "ARC" Donskoy ",

3, Nauchny gor., Zernograd, 347740, Russia

\section{Elena V. Dubina}

Head of the laboratory of information, digital and biotechnology

E-mail: lenakrug1@rambler.ru

FSBSI Federal Scientific Rice Centre

3, Belozerny, Krasnodar, 350921, Russia 


\section{ПОТРЕБЛЕНИЕ И ВЫНОС БИОГЕННЫХ ЭЛЕМЕНТОВ РАСТЕНИЯМИ РИСА ПРИ ПОСЕВЕ ОБОГАЩЕННЫМИ ЦИНКОМ СЕМЕНАМИ}

При выращивании на лугово-черноземной тяжелосуглинистой среднемощной слабогумусной почве со следующими агрохимическими показателями: гумус 3,2 \%, азот аммонийный - 12,64 мг/кг, фосфор подвижный 52,4 мг/кГ, калий подвижный 222,0 мг/кг, подвижный цинк 0,83 мг/кГ, реакция почвенного раствора нейтральная (Центральная агроклиматическая зона Краснодарского края) изучали влияние предпосевной обработки семян риса 0,05, 0,1, 0,5, 1,0 и 1,5 \% водными растворами сульфата цинка на потребление и вынос растениями биогенных элементов. Растения выращивали на фоне $N_{120} P_{80} K_{60}$ Содержание в растениях азота, фосфора и калия определяли по методике Куркаева, цинка - по прописи Ягодина и Саблиной. Установлено, что предпосевная обработка семян риса цинком (1,0\% водный раствор) сопровождается ростом потребления растениями цинка на 19,8 \%, азота - 10,3 \%, фосфора - 11,1 \%, калия - 11,0 \%. При этом, среднесуточное (в среднем за вегетационный период) поглощение азота возрастает на 14,2 \%, фосфора - 14,8 \%, калия - 21,1\% и цинка - 22,0 \%. При оптимизации обеспеченности растений риса цинком повышается вынос урожаем азота - 3,23 - 14,73 кг/га (2,5 - 11,4 \%), фосфора - 1,33 - 7,10 (2,3-12,3), калия 4,61 - 16,25 кг/га (3,4 - 11,9 \%). Затраты этих элементов на формирование агроценозом единицы урожая зерна и соответствующего количества побочной продукции возрастают несущественно, а использование растениями риса из удобрений азота увеличивается на 2,69 - 12,28 \%, фосфора - 1,66 - 8,88 \% и калия $7,68-27,08 \%$.

Ключевые слова: рис, цинковое удобрение, обработка семян, потребление биогенных элементов, вынос биогенных элементов с урожаем.

\section{CONSUMPTION AND REMOVAL OF NUTRIENTS BY RICE PLANTS WHEN SOWING ZINC-RICH SEEDS}

The effect of presowing treatment of rice seeds with $0.05,0.1,0.5,1.0$ and $1.5 \%$ aqueous solutions of zinc sulfate on consumption and removal of biogenic elements by plants was studied when grown on meadow-chernozemic heavy loamy medium-thick low-humus soil with the following agrochemical indicators: humus $3.2 \%$, ammonium nitrogen - $12.64 \mathrm{mg} / \mathrm{kg}$, mobile phosphorus $52.4 \mathrm{mg} / \mathrm{kg}$, mobile potassium $222.0 \mathrm{mg} / \mathrm{kg}$, mobile zinc 0.83 $\mathrm{mg} / \mathrm{kg}$, the reaction of the soil solution is neutral (Central agroclimatic zone of the Krasnodar region). Plants were grown against a background of $N_{120} P_{80} K_{60^{\circ}}$ The content of nitrogen, phosphorus and potassium in plants was determined by the method of Kurkaev, zinc - by the method of Yagodin and Sablina. It was established that pre-sowing treatment of rice seeds with zinc (1.0\% aqueous solution) is accompanied by an increase in the consumption of zinc by rice plants by $19.8 \%$, nitrogen - 10.3, phosphorus - $11.1 \%$, potassium - $11.0 \%$. At the same time, the average daily (average for the growing season) absorption of nitrogen increases by $14.2 \%$, phosphorus - 14.8, potassium - 21.1 and zinc $-22.0 \%$. When optimizing the supply of rice plants with zinc, the yield of nitrogen increases - 3.23-14.73 kg / ha (2.5-11.4\%), phosphorus - 1.33-7.10 (2.3-1.3), potassium - 4.61-16.25 kg / ha (3.4-11.9 \%). The cost of these elements for the formation of an agrocenosis unit of grain yield and the corresponding amount of by-products increases insignificantly, and the use of rice plants from nitrogen fertilizers increases by $2.69-12.28 \%$, phosphorus - 1.66-8.88 and potassium - 7.68-27.08\%.

Keywords: rice, zinc fertilizer, seed treatment, consumption of nutrients, removal of nutrients from the crop.

\section{Введение}

Минеральное питание - основа роста и развития растений. Элементы минерального питания участвуют в построении биологических молекул, вовлечены в самые разнообразные физиологические и биохимические процессы: построение клеточных и тканевых структур растений, работу ферментов и электронтранспортных цепей, передачу гормональных сигналов и функционирование генетического аппарата. Замедление роста, нарушения в формировании вегетативных и генеративных органов, повышенная чувствительность к инфекционным заболевани- ям - типичные симптомы, вызываемые недостатком у растений элементов минерального питания. При их остром дефиците отклонения в жизненном цикле растений становятся катастрофичными, приводящими к их преждевременной гибели растительного организма. Нарушения в минеральном питании растений вследствие дефицита элементов или неблагоприятных почвенно-климатических условий - глобальная проблема как по масштабам распространения, так и по влиянию на здоровье человека. Недостаток продуктов питания и пища низкого качества - основные причины распространения на Земле голода, 
недоедания и различных заболеваний [1].

С минеральным питанием растений в условиях недостатка или избытка химических элементов в почве связано много важных эколого-физиологических проблем. Для сбалансированного питания растений в целях получения максимальных сборов высококачественной сельскохозяйственной продукции особенно важен строго дифференцированный подход к применению удобрений с учетом содержания в почве доступных для растений форм элементов питания и других почвенных и климатических факторов, особенностей питания различных сельскохозяйственных культур. Долевое участие удобрений в формирование урожая зависит от почвенно-климатических условий и составляет в Нечерноземной зоне $40 \%$, лесостепной - $30 \%$, степной - $20 \%$, сухостепной и полупустынной - $10 \%$, при орошении 40 \%. Оплата 1 кг д. в. снижается с 5,3 кг зерновых единиц в южно-таежной зоне до 3,9 кг зерновых единиц на неорошаемых землях сухостепной зоны.

«Противники химизации земледелия совершенно правильно отмечают, - писал академик Б.А. Ягодин, что химические загрязнения опасны, так как приводят к разрушению природы и болезням человека». Мы полностью согласны с этим положением, но мы за расширенное сельскохозяйственное производство и за применение удобрений как одного из самых действенных методов повышения урожая. И в этом нет противоречий, так как удобрения - элементы, из которых состоят наша планета, почва и все живущее на ней. Применяя удобрения, мы обогащаем почву уже имеющимися в ней элементами, но теми, которых недостаточно для получения высоких урожаев, что не позволяет иметь качественную продукцию для питания людей. Природа требует воспроизводства, почва нуждается в возврате элементов, которые выносятся с урожаем. Без внесения дополнительных количеств удобрений, другого радикального метода увеличения урожайности нет. Время беспощадной эксплуатации почв, деградации и разрушения должно остаться позади... Уровни применения удобрений в России значительно ниже, чем в странах Европы, но, несмотря на низкое применение удобрений, роль агрохимии нельзя занижать. Лучше нет эколога, чем агрохимик-почвовед. Знания почвы, растений, круговорота химических элементов в природе, их влияния на организм человека и животных позволяют ему наиболее квалифицированно решать насущные проблемы» [13].

\section{Цель исследований}

Изучить влияние предпосевного обогащения цинком семян риса на содержание, потребление, вынос и коэффициенты использования растениями биогенных элементов из удобрений.

\section{Материал и методы}

Исследования проведены в соответствии с общепринятыми методиками в полевом опыте на рисовой оросительной системе ФГБУ ЭСОС «Красная» (Центральная агроклиматическая зона
Краснодарского края) на лугово-черноземной тяжелосуглинистой среднемощной слабогумусной почве со следующими агрохимическими показателями: гумус 3,2 \%, азот аммонийный - 12,64 мг/кг, фосфор подвижный 52,4 мг/кг, калий подвижный 222,0 мг/кг, подвижный цинк 0,83 мг/кг, реакция почвенного раствора нейтральная.

Площадь делянок - 25 м², варианты размещались рендомизированно, повторность - 4-кратная. Предшественник оборот пласта многолетних трав. Посев проводился в первой декаде мая (оптимальный срок), рядовым способом на глубину 1,0 - 1,5 см, с нормой высева 7 млн. всхожих зерен на 1 га. Режим орошения - укороченное затопление. Действие предпосевной обработки семян цинком на потребление и вынос биогенных элементов изучали на фоне $\mathrm{N}_{120} \mathrm{P}_{80} \mathrm{~K}_{60}$. Для создания фона использовали аммофос, калий хлористый, карбамид. Обработку семян проводили полусухим способом (расход рабочего раствора 10 л/т семян) 0,05, 0,1, 0,5, 1,0 и 1,5 \% водными растворами сульфата цинка. Урожай учитывали поделяночно, с пересчетом массы зерна на стандартную влажность и чистоту. Содержание в растениях азота, фосфора и калия определяли по методике Куркаева, цинка - по прописи Ягодина и Саблиной [4].

Статистическая оценка результатов исследований проведена с использованием метода дисперсионного анализа [7].

\section{Результаты и обсуждение}

Для растений риса дефицит, оптимум и избыток цинка в зерне <20, 20 - 30 и > 30 мг/кг, надземных вегетативных органах: в фазе кущения < 20, 20 - 30 и $>30$, выметывания $<15,15-25$ и $>25$, полной спелости зерна $<10,10-25$ и $>25$ мг/кг сухой массы соответственно [10, 11].

Максимальное содержание цинка в надземных вегетативных органах растений риса приходится на фазу кущения. Затем оно постепенно снижается. В конце вегетации растений риса цинк аттрагируется из вегетативных органов в репродуктивные. Поглощенный растением цинк распределяется между вегетативными органами и зерном с небольшим преимущественным (6 - 11 \%) поступлением в зерно (рис. 1).

По мере увеличения концентрации рабочего раствора, а, следовательно, обеспеченности растений цинком, его содержание в них повышалось в фазе кущения на 1,5 - 17,0 \%, выметывания - 6,3 - 18,2 \%, по завершению онтогенеза - в листостебельной массе на 8,8 - 21,1 \% и 3,2 - 8,6 \% в зерне. В интервале концентраций рабочего раствора 0,05 - 1,5 \% достоверного увеличения содержания цинка в зерне риса не наблюдалось $\left(\mathrm{HCP}_{05}=1,2\right)$.

В соответствии с градациями обеспеченности растений риса цинком, разработанной А.Х. Шеудженом, его содержание в зерне и надземных вегетативных органах было оптимальным (рис. 1). 


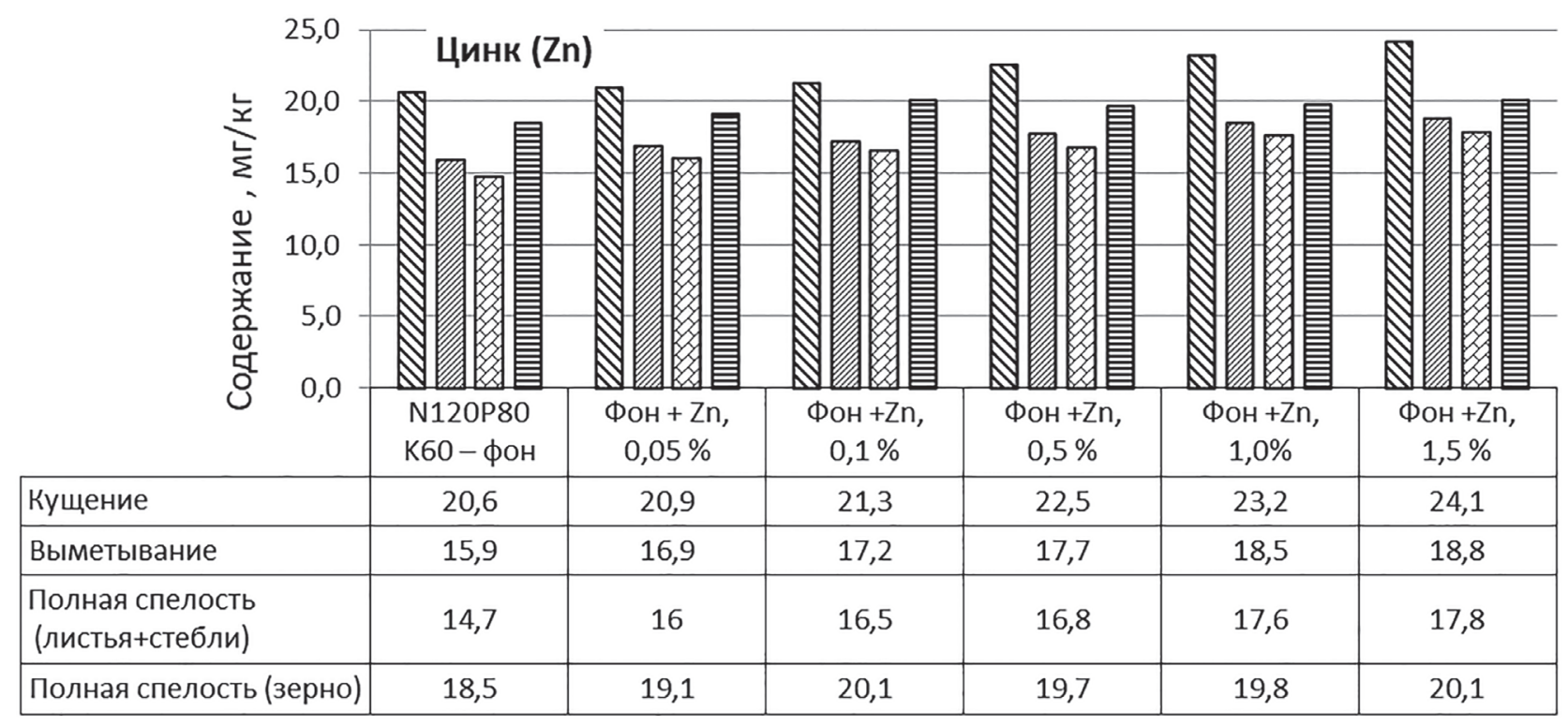

$\mathbb{\nabla}$ Кущение 囚Выметывание

\section{Рисунок 1. Динамика содержания цинка в растениях риса}

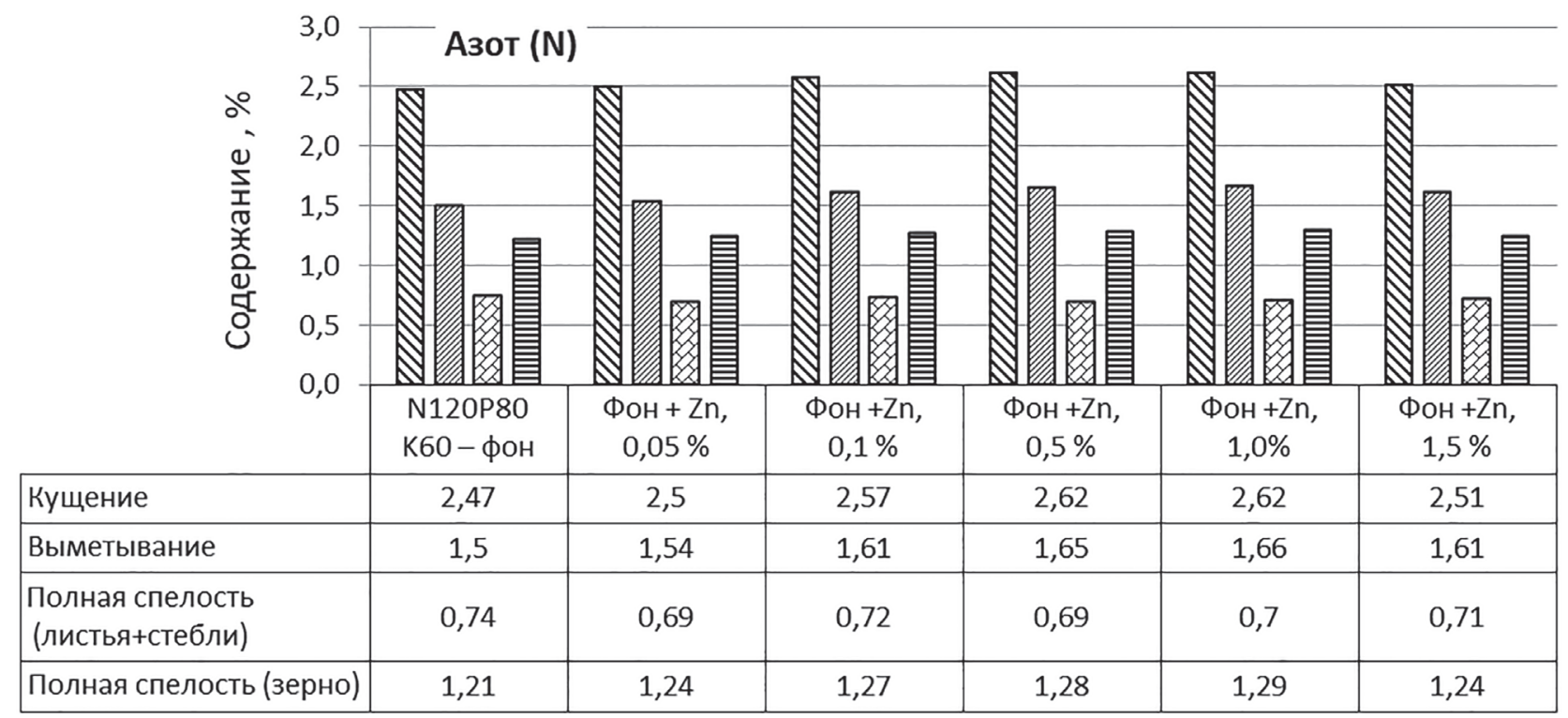

\Кущение

\section{Рисунок 2. Динамика содержания азота в растениях риса}

Дефицит, оптимум и избыток азота в растениях риса составляет: в зерне $<1,0,1,0-1,5,>1,5 \%$, в надземных вегетативных органах в фазе кущения $<2,5,2,5-3,5,>3,5 \%$, выметывания $<1,0,1,0-2,0$, $>2,0 \%$, полной спелости зерна $<0,5,0,5-1,0,>1,0 \%$ сухой массы соответственно $[10,11]$.

При внесении азотного удобрения из расчета $\mathrm{N}_{120}$ растения риса не испытывали дефицита этого элемента на протяжении всего вегетационного периода. Повышение обеспеченности растений цинком стимулирует поглощение азота. Так, в фазе кущения в опытных растениях его содержалось больше на 0,03 - 0,15 \% по сравнению с контролем, выметывания - 0,04 - 0,16\%, полной спелости - в зерне на 0,03 - 0,08 \%, а листостебельной массе - меньше на 0,01-0,05\%. Такая тенденция проявлялась во все годы исследований. Обусловлено это тем, что растения, выросшие из обогащенных цинком семян, лучше развивались и активнее использовали азот почвы и удобрений (рис. 2).

Во все фазы вегетации риса максимальное содержание азота отмечалось в растениях, выросших из 
семян обработанных 1,0 \% водным раствором цинка. На этом варианте содержание его в надземных вегетативных органах превышало контроль в фазы кущения и выметывания на 0,15 и 0,16 \% сухой массы. На этом же варианте наблюдается повышенная аттракция азота из вегетативных органов в генеративные. В результате этого его содержание в листостебельной массе было на 0,04 \% меньше, а в зерне, наоборот, на 0,08 \% больше, чем в контроле.

Дефицит, оптимум и избыток фосфора в растениях риса составляет: зерне <0,50, 0,50 - 0,75, $>0,75 \%$, надземных вегетативных органах в фазе кущения $<0,60,0,60-0,75,>0,75 \%$, выметывания $<0,45,0,45-0,70,>0,70 \%$, полной спелости зерна
$<0,20,0,20-0,25,>0,25 \%$ сухой массы соответственно [10, 11].

Наибольшее содержание фосфора в растениях риса характерно для вегетативного периода развития, а к генеративному - оно значительно уменьшается. Так, если в фазе кущения риса в растениях контрольного варианта он содержался в количестве 0,61\% сухой массы, то в выметывание и созревания снизилось соответственно на 0,04 и 0,39 \%. Резкое уменьшение содержания фосфора в надземных вегетативных органах растений риса в фазе созревания обусловлено его аттракцией в зерновки. Содержание фосфора в зерне превосходило таковое в листостебельной массе в 2,86 раз (рис. 3).

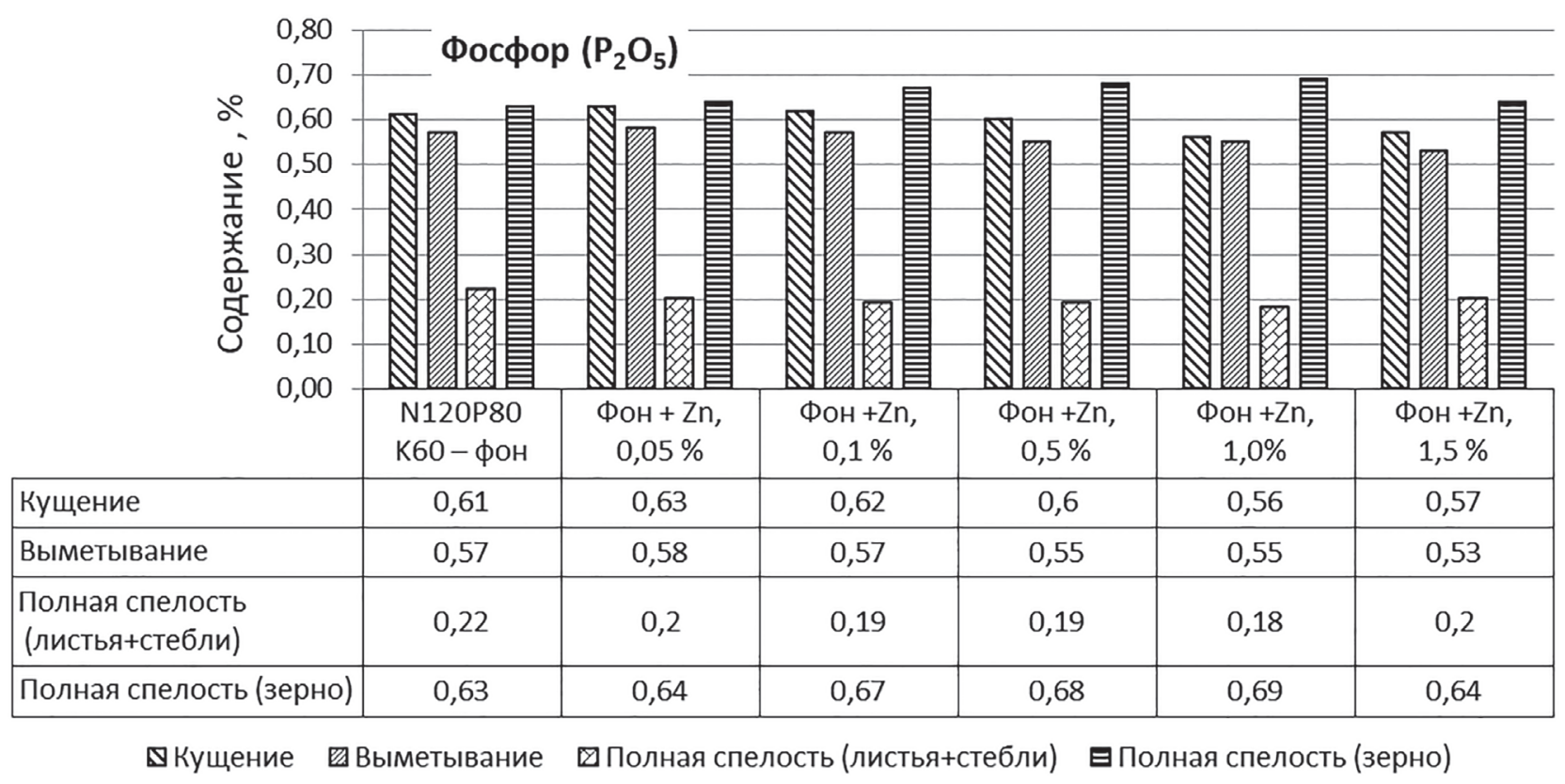

\section{Рисунок 3. Динамика содержания фосфора в растениях риса}

Действие цинка на поглощение фосфора растениями риса зависело от концентрации микроэлемента в растворе, использованном для предпосевной обработки семян. Положительное влияние на его содержание в растениях риса в фазе кущения и выметывания оказала предпосевная обработка семян 0,05 \% водным раствором цинка. При более высоких концентрациях микроэлемента в растениях содержалось фосфора меньше, что может быть связано с более интенсивным их ростом (накоплением биомассы). В фазе полной спелости зерна содержание фосфора в листостебельной массе у этих растений меньше, чем у контрольных, что может быть вызвано влиянием цинка на интенсивность его аттракции. Это предположение подтверждается большим количеством фосфора в зерне из вариантов с посевом обогащенными семенами. М.Я. Школьник предполагает, что одной из возможных причин подавления поглощения фосфора растениями под воздействием цинка может быть подавление актив- ности дефосфорилирующих ферментов - АТФ-азы и кислой $\beta$-глицерофосфатазы [12].

Дефицит, оптимум и избыток калия в растениях риса составляет: зерне <0,30, 0,30 - 0,40, >0,40 \%, надземных вегетативных органах в фазе кущения $<2,0,2,0-3,5,>3,5 \%$, выметывания $<1,5,1,5-3,0$, $>3,0 \%$, полной спелости зерна $<1,0,1,0-2,5>2,5 \%$ сухой массы соответственно $[10,11]$.

Независимо от системы удобрения в наибольшем количестве калий содержался в растениях риса в фазе кущения, затем оно неуклонно снижалось до завершения вегетации. Растения из всех вариантов, включая контроль, обеспечены калием в достаточном количестве, что подтверждается оптимальным его содержанием на протяжении всей вегетации (рис. 4).

Предпосевная обработка семян риса цинком стимулировала поглощение калия растениями на протяжении всего вегетационного периода. Наблюдения за динамикой содержания калия в надземных вегетативных органах растений показали, что оно 
было больше, чем в контроле в фазе кущения на 0,03 - 0,08 \%, выметывания - 0,03-0,09\%, полной спелости зерна - 0,02 - 0,08 \% сухой массы. В то же время, различия в содержании калия в зерне между контрольным и опытными вариантами были весьма незначительными - превышение составило всего лишь 0,02 \% независимо от концентрации цинка в растворе, использованном для предпосевной обработки семян риса.

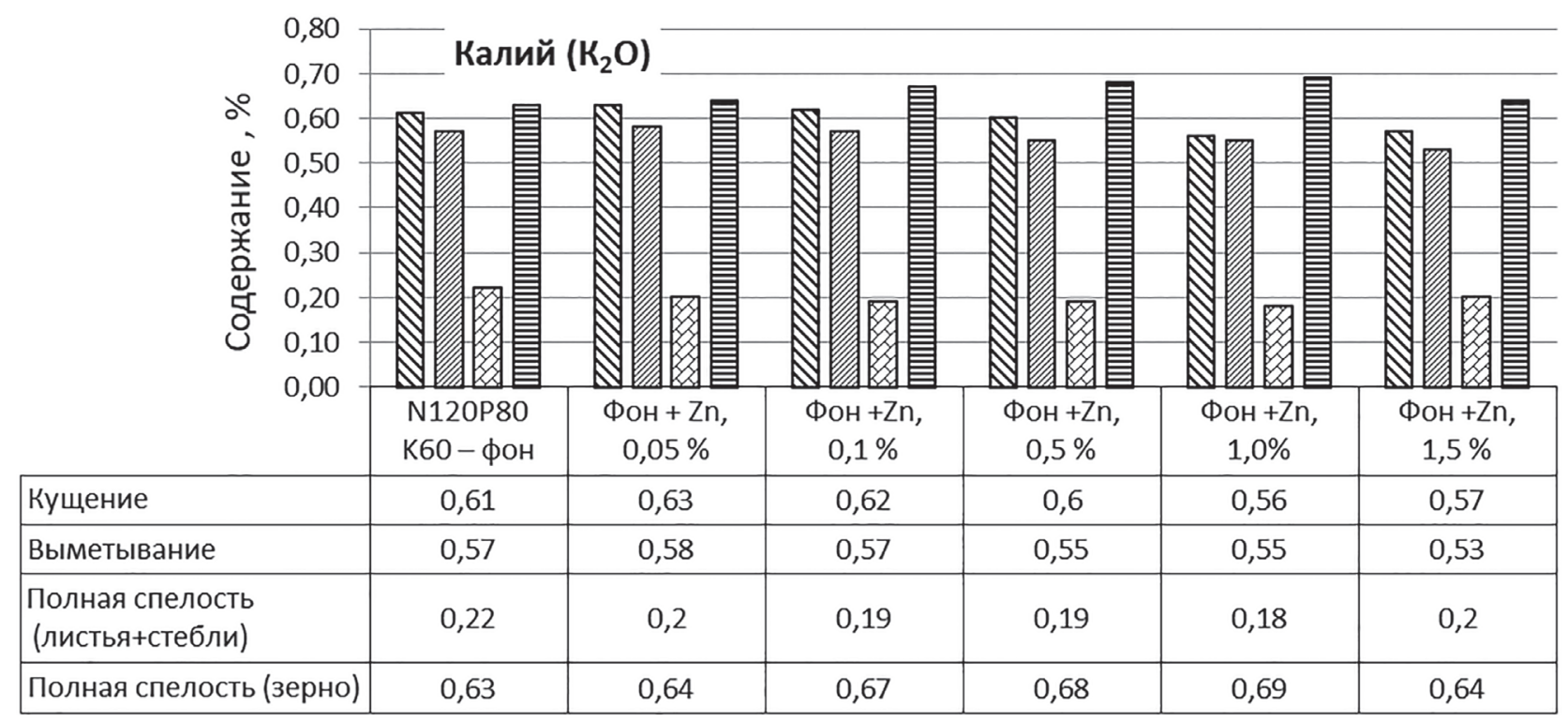

\$Кущение 囚Выметывание छПолная спелость (листья+стебли) छПолная спелость (зерно)

\section{Рисунок 4. Динамика содержания калия в растениях риса}

Потребление биогенных элементов растениями. Потребность растений в элементах питания обусловливается их биологической природой и генотипом. Сам процесс потребления зависит от интенсивности нарастания биомассы отдельных органов и изменения их минерального состава с возрастом растения [3, 14].

Основоположник отечественной агрохимической научной школы Д.Н. Прянишников, подчеркивая наличие специфики в питании каждого растения, писал: «Растения не воспринимают находящихся в окружающем растворе веществ пассивно, вместе с транспирационным током воды. Достаточно убедительным доказательством этого факта является то обстоятельство, что состав зольных веществ растений не отвечает составу раствора, окружающего корни. Растение воспринимает минеральные вещества в ином соотношении. Мало того, разные растения при выращивании на одинаковом растворе или на одной и той же почве обнаруживают разный состав золы, хотя и подверженный некоторым колебаниям, но для каждого типа растения сохраняющий известные типичные черты... Большой заслугой нашей русской, советской агрохимии является выдвижение на первый план в изучении питания растений тесной взаимной связи между условиями питания и обменом веществ у растений. Это направление, оказавшееся чрезвычайно плодотворным, позволи- ло по-новому подойти к сравнительному изучению питания культурных растений, отличающихся своими физиологическими особенностями, характером обмена веществ и отношением к условиям питания. В последнее время это направление исследований, в основном обязанное советской агрохимии, получило большое значение при изучении удобрений как средства не только повышения величины урожая, но и изменения его химического состава, улучшения качества урожая» [5].

О тесной зависимости между урожаем и количеством использованных растением элементов питания совершенно определенно высказывался академик В.Р. Вильямс: «Раз зольная пища растений составляет, безусловно, необходимый элемент органического вещества, то очевидно, что для создания определенного его количества требуется строго соответствующее количество зольной пищи растений» [2]. В свете этих высказываний представляет большой интерес изучение потребности растений в элементах питания при разной величине урожая. На это указывал также основоположник учения о рациональном питании растений К.А. Тимирязев. Он задавал вопрос: «Но что же нужно для обеспечения урожая?» и сам на него отвечал: «Прежде всего, конечно, знакомство с потребностями растения и умение их удовлетворить» [6]. Потребность растений должна всегда пониматься широко, включая все факторы роста, однако 
в данном случае нас в первую очередь, интересует потребность растений в минеральном питании. Кроме установления общей потребности растений в минеральных элементах для построения урожая определенного размера, т.е. так называемого «биологического выноса», надо учитывать и ее изменения во время роста.

Для количественной характеристики состояния минерального питания растений наряду с определением относительного содержания элементов питания, рассчитывают и абсолютное их потребление по фазам вегетации или за весь вегетационный период $[14,15]$.

Таблица 1. Динамика потребления цинка, азота, фосфора и калия растениями риса, мг/растение

\begin{tabular}{|c|c|c|c|c|}
\hline \multirow{3}{*}{ Вариант } & \multicolumn{4}{|c|}{ Фаза вегетации } \\
\hline & \multirow{2}{*}{ кущение } & \multirow{2}{*}{ выметывание } & \multicolumn{2}{|c|}{ полная спелость } \\
\hline & & & листья + стебли & зерно \\
\hline \multicolumn{5}{|c|}{ Цинк (Zn) } \\
\hline $\mathrm{N}_{120} \mathrm{P}_{80} \mathrm{~K}_{60}-$ фон & 0,024 & 0,056 & 0,052 & 0,079 \\
\hline Фон + Zn, 0,05\% & 0,029 & 0,061 & 0,057 & 0,082 \\
\hline$\Phi \mathrm{OH}+\mathrm{Zn}, 0,1 \%$ & 0,030 & 0,063 & 0,061 & 0,089 \\
\hline$\Phi \mathrm{OH}+\mathrm{Zn}, 0,5 \%$ & 0,032 & 0,067 & 0,063 & 0,090 \\
\hline$\Phi \mathrm{OH}+\mathrm{Zn}, 1,0 \%$ & 0,030 & 0,070 & 0,067 & 0,090 \\
\hline$\Phi \mathrm{OH}+\mathrm{Zn}, 1,5 \%$ & 0,027 & 0,069 & 0,065 & 0,088 \\
\hline \multicolumn{5}{|c|}{ Азот (N) } \\
\hline $\mathrm{N}_{120} \mathrm{P}_{80} \mathrm{~K}_{60}-$ фон & 28,65 & 53,25 & 26,20 & 51,42 \\
\hline Фон + Zn, 0,05\% & 34,75 & 55,90 & 24,77 & 53,44 \\
\hline ФоH + Zn, 0,1 \% & 36,75 & 59,41 & 26,71 & 56,52 \\
\hline$\Phi \mathrm{OH}+\mathrm{Zn}, 0,5 \%$ & 36,42 & 62,54 & 25,94 & 57,73 \\
\hline$\Phi \mathrm{OH}+\mathrm{Zn}, 1,0 \%$ & 34,06 & 63,08 & 26,67 & 58,95 \\
\hline$\Phi \mathrm{OH}+\mathrm{Zn}, 1,5 \%$ & 28,61 & 59,09 & 25,92 & 54,31 \\
\hline \multicolumn{5}{|c|}{ Фосфор $\left(\mathrm{P}_{2} \mathrm{O}_{5}\right)$} \\
\hline $\mathrm{N}_{120} \mathrm{P}_{80} \mathrm{~K}_{60}-$ фон & 7,08 & 20,24 & 7,79 & 26,78 \\
\hline Фон + Zn, 0,05 \% & 8,76 & 21,05 & 7,18 & 27,58 \\
\hline$\Phi \mathrm{OH}+\mathrm{Zn}, 0,1 \%$ & 8,87 & 20,69 & 7,05 & 29,82 \\
\hline$\Phi \mathrm{OH}+\mathrm{Zn}, 0,5 \%$ & 8,34 & 20,84 & 7,14 & 30,67 \\
\hline$\Phi \mathrm{OH}+\mathrm{Zn}, 1,0 \%$ & 7,28 & 20,90 & 6,86 & 31,53 \\
\hline$\Phi \mathrm{OH}+\mathrm{Zn}, 1,5 \%$ & 6,50 & 14,45 & 7,30 & 28,03 \\
\hline \multicolumn{5}{|c|}{ Калий $\left(\mathrm{K}_{2} \mathrm{O}\right)$} \\
\hline $\mathrm{N}_{120} \mathrm{P}_{80} \mathrm{~K}_{60}-$ фон & 26,10 & 75,26 & 69,38 & 14,02 \\
\hline Фон + Zn, 0,05 \% & 31,69 & 78,04 & 71,08 & 15,08 \\
\hline Фон $+\mathrm{Zn}, 0,1 \%$ & 32,75 & 80,07 & 71,23 & 15,58 \\
\hline$\Phi \mathrm{OH}+\mathrm{Zn}, 0,5 \%$ & 32,11 & 83,76 & 76,70 & 15,78 \\
\hline$\Phi \mathrm{OH}+\mathrm{Zn}, 1,0 \%$ & 30,29 & 83,98 & 76,58 & 16,00 \\
\hline$\Phi \mathrm{OH}+\mathrm{Zn}, 1,5 \%$ & 26,45 & 81,11 & 73,36 & 15,33 \\
\hline
\end{tabular}

Предпосевная обработка семян цинком способствовала росту потребления растениями этого элемента в межфазные периоды всходы-кущение, кущение-выметывание и выметывание-полная спелость зерна соответственно на 0,003- 0,008, 0,005 - 0,014 и 0,008 - 0,026 мг/растение. Наибольшее потребление цинка во все фазы вегетации отмечено у растений риса, выросших из семян, обработанных 1,0% во-
Потребление цинка растениями риса возрастает в процессе их роста и развития. За вегетативный период развития, т. е. от всходов до выметывания в надземных вегетативных органах растений из контрольного варианта цинка накапливалось 42,7 \% от общего количества этого элемента, поглощаемого за весь период вегетации риса. На генеративный период развития, т. е. межфазный период выметывание-полная спелость зерна приходится 57,3% цинка усвоенного растениями из почвы и внесенных удобрений (табл. 1). 
Предпосевное обогащение семян цинком позитивно сказывается на динамике потребления азота растениями во все фазы вегетации. Так, обработка семян 1,0 \% раствором микроэлемента увеличивала его потребление в межфазный период всходы-кущение на 5,41 мг/растение или на 18,9 \%, кущениевыметывание - на 9,83 мг/растение или 18,5\%, выметывание-полная спелость - на 8,0 мг/растение или $10,3 \%$.

Степень влияния цинка на потребление растениями риса фосфора зависит от концентрации микроэлемента в растворе, которым обрабатывали семена перед посевом, и фазы вегетации. Наибольшее количество фосфора - на 11,1 \% или 3,82 мг/растение потребляли растения из семян, обработанных перед посевом 1,0 \% раствором цинка. Предпосевная обработка семян риса цинком способствовала увеличению потребления растениями калия в течение всего вегетационного периода. Под ее воздействием оно возросло в межфазные периоды всходы-кущение, кущение-выметывание и выметывание-полная спе- лость на 0,35 - 6,65, 2,78 - 8,72 и 2,76 - 9,18 мг или на 1,3 - 25,5, 3,7 - 11,6 и 3,3 - 11,0 \%. Наибольшее потребление калия отмечено у растений из семян, обработанных перед посевом 1,0 \% водным раствором цинка.

Имеются различия и в интенсивности потребления биогенных элементов растениями риса. Наиболее интенсивно потребляется калий, за ним в убывающем порядке следуют азот, фосфор и цинк (табл. 2). Предпосевная обработка семян риса цинком стимулировала интенсивность потребления биогенных элементов растениями риса. В зависимости от концентрации цинка в рабочем растворе, использованном для предпосевной обработки семян, скорость поглощения одноименного элемента возрастала на $5,5-22,0 \%$, азота - 1,6 - 14,2\%, фосфора $1,4-14,8 \%$, калия - на 9,9-21,1\%. С наибольшей скоростью биогенные элементы потреблялись растениями при посеве семенами, обработанными перед посевом 1,0 \% раствором цинка.

Таблица 2. Интенсивность потребления биогенных элементов растениями риса, мг/сут.

\begin{tabular}{|c|c|c|c|c|}
\hline Вариант & Цинк (Zn) & Азот (N) & Фocpop $\left(\mathrm{P}_{2} \mathrm{O}_{5}\right)$ & Калий $\left(\mathrm{K}_{2} \mathrm{O}\right)$ \\
\hline $\mathrm{N}_{120} \mathrm{P}_{80} \mathrm{~K}_{90}-$ фон & 0,00109 & 0,636 & 0,283 & 0,648 \\
\hline ФоH + Zn, 0,05\% & 0,00115 & 0,646 & 0,287 & 0,712 \\
\hline ФоH + Zn, 0,1\% & 0,00125 & 0,694 & 0,307 & 0,723 \\
\hline Фон + Zn, 0,5 \% & 0,00130 & 0,709 & 0,320 & 0,784 \\
\hline$\Phi \mathrm{OH}+\mathrm{Zn}, 1,0 \%$ & 0,00133 & 0,726 & 0,325 & 0,785 \\
\hline$\Phi \mathrm{OH}+\mathrm{Zn}, 1,5 \%$ & 0,00130 & 0,680 & 0,299 & 0,752 \\
\hline
\end{tabular}

Таким образом, предпосевная обработка семян риса цинком (1,0 \% водный раствор) сопровождается ростом потребления растениями риса одноименного элемента на 19,8 \%, азота - 10,3, фосфора $11,1 \%$, калия - $11,0 \%$. При этом среднесуточное (в среднем за вегетационный период) поглощение азота возрастало на $14,2 \%$, фосфора - 14,8, калия 21,1 и цинка $-22,0 \%$.

Вынос элементов питания урожаем риса и коэффициенты их использования растениями из удобрений. Вынос биогенных элементов с урожаем определяется с одной стороны обеспеченностью ими растений, а с другой - развитием этих растений. При посеве обогащенными цинком семенами формирующиеся растения были выше контрольных, имели большую массу и ассимиляционную поверхность. Лучшее развитие позволило им извлекать из почвы и удобрений большее количество цинка, азота, фосфора и калия. Это, безусловно, должно отразиться на выносе элементов питания и их затратах на формирование урожая.

При посеве обогащенными цинком семенами увеличивался вынос одноименного элемента зерном и соломой соответственно на 8,51 - 21,41 и 10,28 - 25,24 г/га. При этом в зависимости от величины урожая и содержания цинка в растениях его хозяйственный вынос увеличился на 18,79 - 46,65 г/га или на 8,6 - 21,5\%. Незначительно, на 1,64 - 4,08 г или на 5,4 - 13,5 \%, но все же возросли и затраты цинка на формирование 1 т урожая зерна риса. Наибольший вынос цинка урожаем риса и затраты на формирование 1 т зерна во все годы исследований были в варианте посева семенами обработанными 1,0 \% водным раствором микроэлемента. С зерном цинка выносится больше, чем с соломой (рис. 5).

Предпосевная обработка семян риса цинком повлияла и на вынос азота, фосфора и калия рисовым агроценозом, который увеличился в зависимости от дозы цинка соответственно на 2,5 - 11,4 \%, $2,3-12,3 \%$ и 3,4 - 11,9 \% (рис. 6). Большая часть азота ( $70 \%)$ и фосфора ( $80 \%)$ выносится с зерном. Увеличение обеспеченности растений цинком усиливает аттракцию этих элементов из вегетативных органов, вследствие чего вынос с соломой азота такой же, как в контроле, а фосфора - меньше на 4,6 - 11,2 \%. Основная масса потребленного растением калия (81 - 82 \%) сосредоточена в листостебельной массе. При посеве обогащенными цинком семенами вынос калия возрастает на 5,0 - 11,9 \%: на 9,3-15,1\% с зерном и 4,1-11,5 \% с соломой. Анализ выноса биогенных элементов показал недостаточное внесение азотного и калийного удобрения. Внесенное их количество компенсирует вынос азота на 83,3 - 90,5 \%, а калия - на 59,0 - 63,9 \%. 


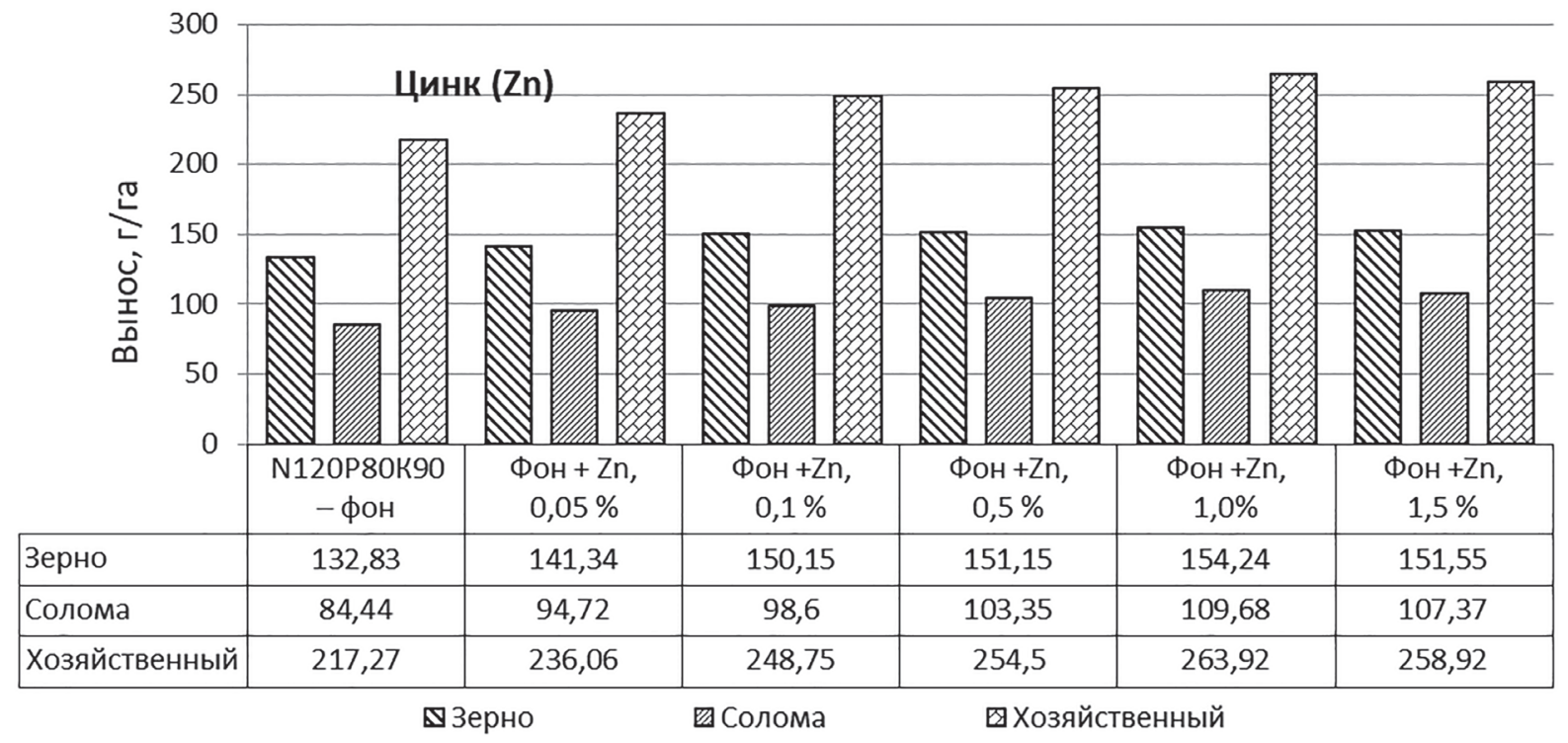

Рисунок 5. Вынос цинка урожаем риса при посеве семенами обогащенными цинком

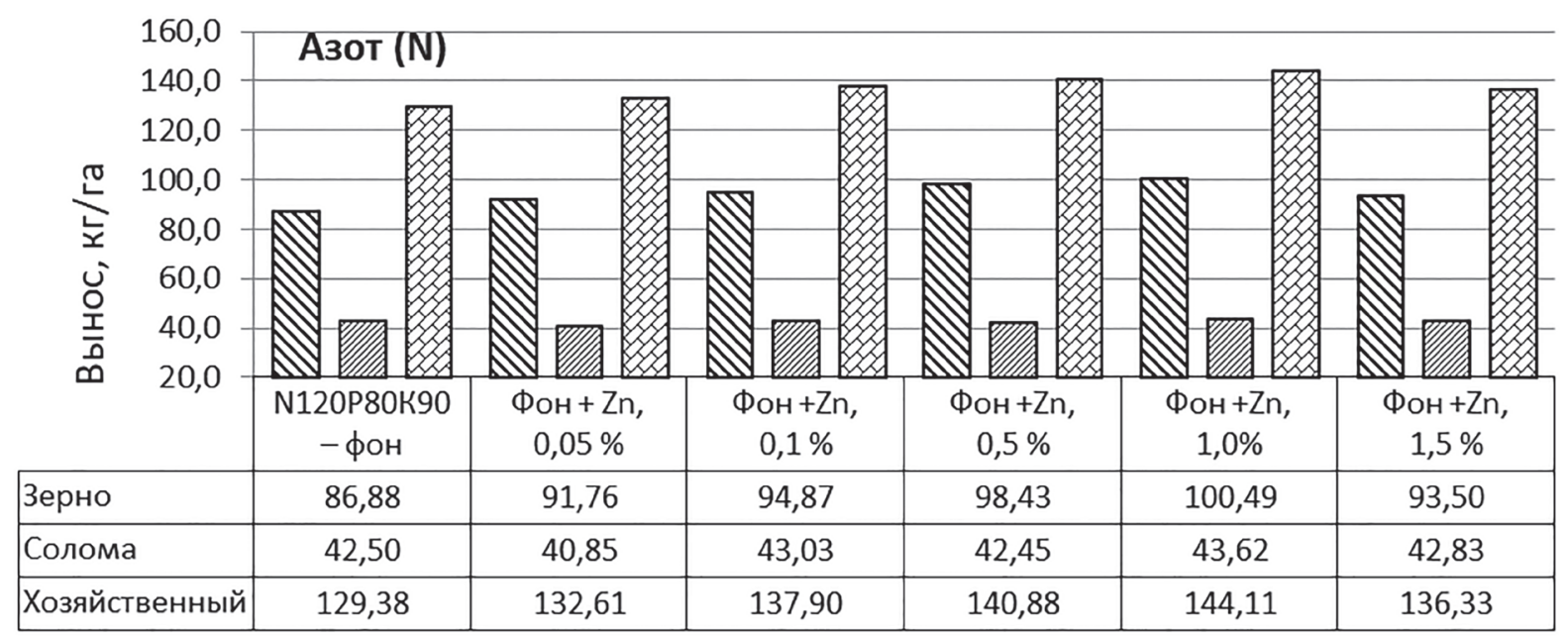

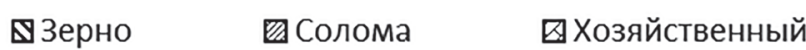

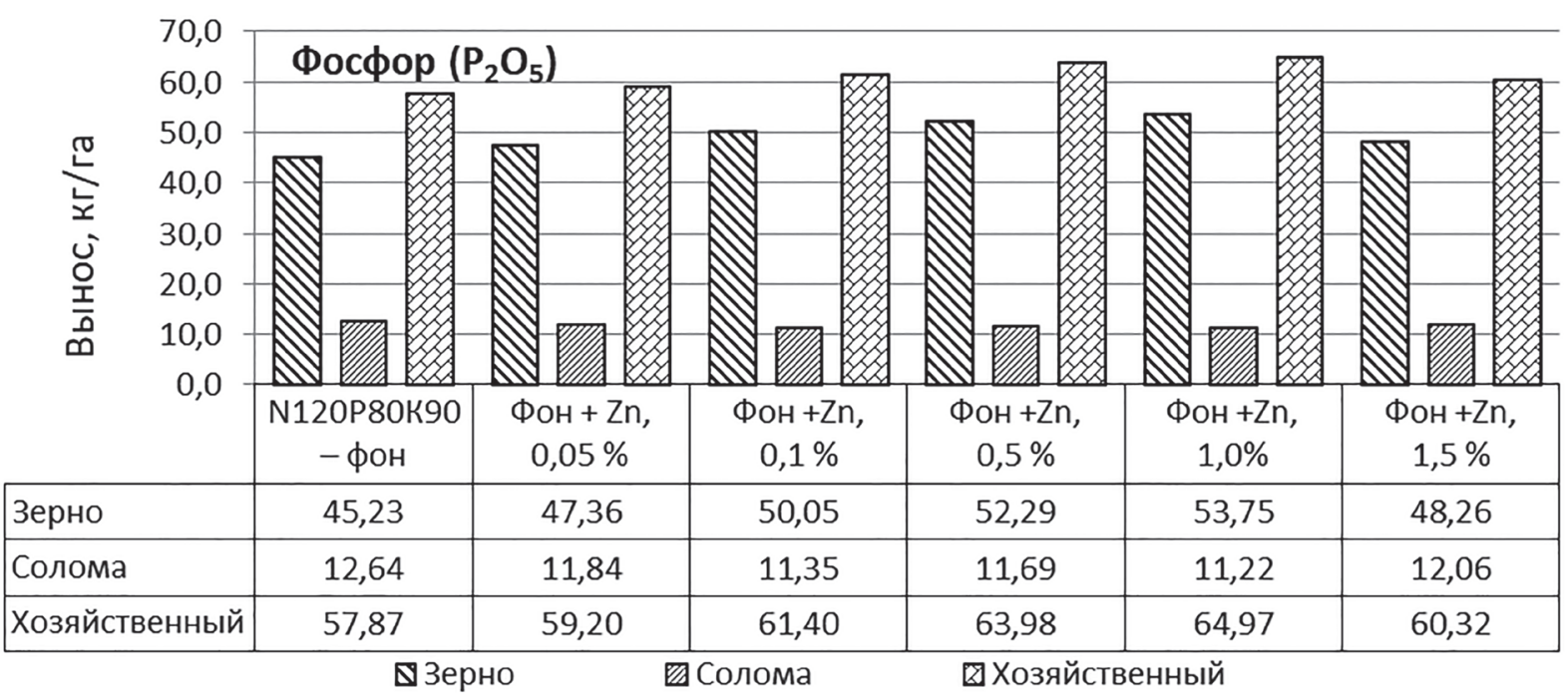




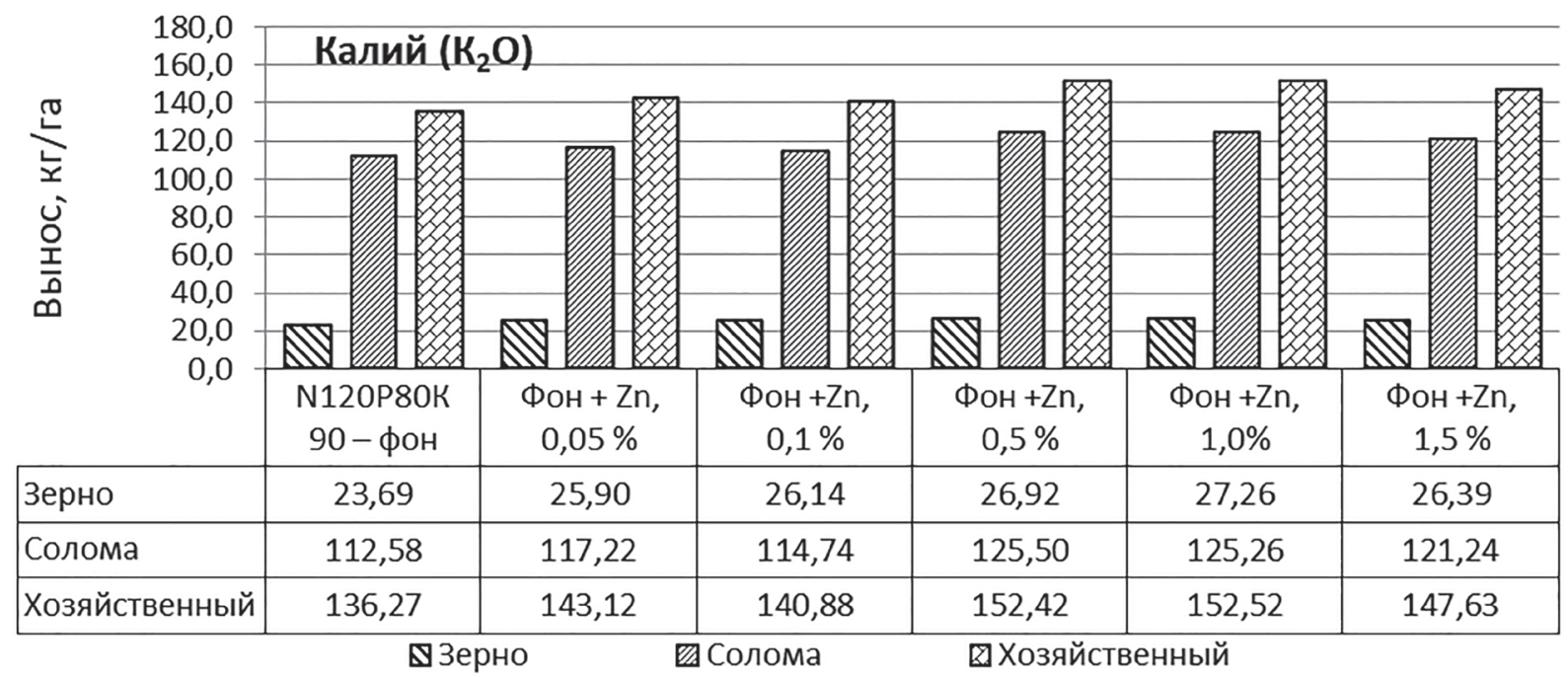

Рисунок 6. Вынос биогенных элементов урожаем риса при посеве семенами обогащенными цинком

Наблюдаемое увеличение затрат на фор- $0,06-0,48,0,16-0,28$ и 0,36-0,84 кг или на 0,3 - 2,7, мирование 1 т зерна риса составляло: азота - 2,0 - 3,2 и 1,9-4,4 \% и было несущественным (рис. 7).

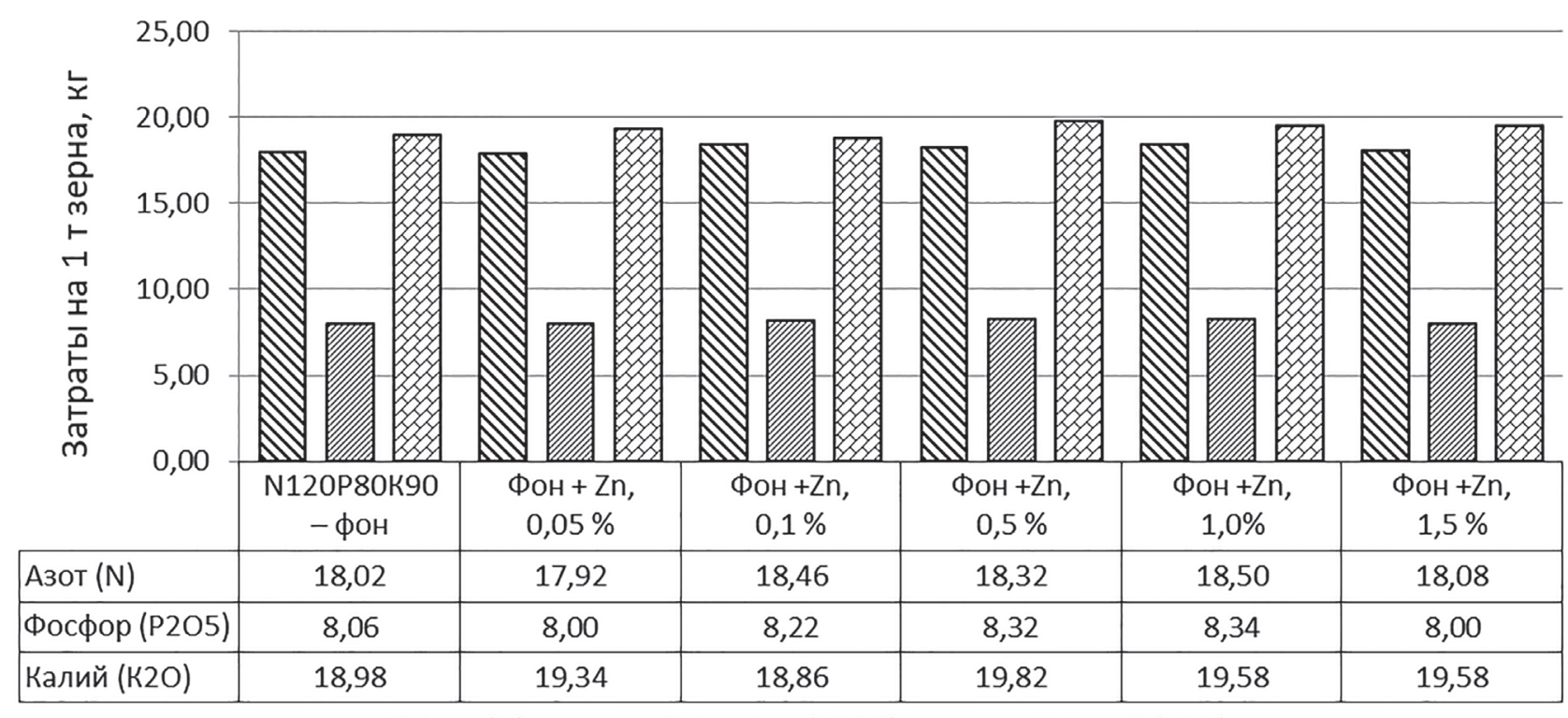

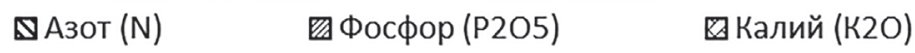

\section{Рисунок 7. Затраты азота, фосфора и калия на формирование 1 т зерна при посеве обогащенными цинком семенами}

Повышение коэффициентов использования растениями элементов питания из удобрений неразрывно связано с оптимизацией условий их произрастания [8]. Одним из приемов оптимизации этих условий является предпосевное обогащение семян микроэлементами, к числу которых относится цинк. Предпосевное обогащение семян риса цинком спо- собствует повышению коэффициента использования растениями риса действующего вещества удобрений: азота на 2,69 - 12,28 \%, фосфора - 1,66 - 8,88, калия - 7,68 - 27,08 \%. Наиболее полно используются растениями элементы питания из удобрений при предпосевной обработке семян риса 1,0 \% водными растворами цинка (табл. 3). 
Таблица 3. Увеличение коэффициента использования растениями риса элементов питания из удобрений при предпосевном обогащении семян цинком, \%

\begin{tabular}{|c|c|c|c|}
\hline Вариант & Азот (N) & Фосфор $\left(\mathrm{P}_{2} \mathrm{O}_{5}\right)$ & Калий $\left(\mathrm{K}_{2} \mathrm{O}\right)$ \\
\hline Фон + Zn, 0,05\% & 2,69 & 1,66 & 11,42 \\
\hline Фон +Zn, 0,1\% & 7,10 & 4,41 & 7,68 \\
\hline Фон + Zn, 0,5\% & 9,58 & 7,64 & 26,92 \\
\hline Фон +Zn, 1,0\% & 12,28 & 8,88 & 27,08 \\
\hline Фон +Zn, 1,5\% & 5,79 & 3,06 & 18,33 \\
\hline
\end{tabular}

Таким образом, предпосевное обогащение семян риса цинком способствует повышению выноса одноименного элемента урожаем на $18,79-46,65$ г/га (8,6 - 21,5 \%), азота - 3,23 - 14,73 кг/га $(2,5-11,4 \%)$, фосфора - 1,33 - 7,10 $(2,3-12,3)$, калия - 4,61 - 16,25 кг/га (3,4 - 11,9\%). Затраты этих элементов на формирование агроценозом единицы урожая зерна и соответствующего количества побочной продукции возрастают несущественно, а использование растениями риса из удобрений азота увеличивается на 2,69 - 12,28 \%, фосфора $1,66-8,88$ и калия $-7,68-27,08 \%$.

\section{Выводы}

Предпосевная обработка семян риса цинком (1,0 \% водный раствор) сопровождается ростом потребления растениями риса цинка на 19,8 \%, азота - 10,3 \%, фосфора - 11,1 \%, калия - $11,0 \%$. При этом среднесуточное (в среднем за вегетационный период) поглощение азота возрастает на 14,2 \%, фосфора $-14,8 \%$, калия $-21,1 \%$ и цинка $-22,0 \%$. При оптимизации обеспеченности растений риса цинком повышается вынос урожаем азота - 3,23 - 14,73 кг/га (2,5-11,4\%), фосфора - 1,33-7,10 (2,3 - 12,3), калия - 4,61 - 16,25 кг/га (3,4-11,9\%). Затраты этих элементов на формирование агроценозом единицы урожая зерна и соответствующего количества побочной продукции возрастают несущественно, а использование растениями риса из удобрений азота увеличивается на 2,69 - 12,28, фосфора - 1,66 - 8,88 и калия $-7,68-27,08 \%$.

\section{ЛИТЕРАТУРА}

1. Битюцкий, Н. П. Минеральное питание растений / Н.П. Битюцкий. - СПб: Изд-во С. Петерб. ун-та, 2014. - 540 с.

2. Вильямс, В.Р. Общее земледелие с основами почвоведения / В.Р. Вильямс. - М.: «Новый агроном», 1931. - 376 с.

3. Журбицкий, З.И. Физиологические и агрохимические основы применения удобрений / З.И. Журбицкий. - М.: Изд-во АН СССР, 1963. - 294 с.

4. Куркаев, В.Т. Агрохимия / В.Т. Куркаев, А.Х. Шеуджен. - Майкоп: ГУРИПП «Адыгея», 2000. - 552 с.

5. Прянишников, Д.Н. Избранные сочинения. Том 1 / Д.Н. Прянишников. - М.: Сельхозиздат, 1952. - 692 с.

6. Тимирязев, К.А. Сочинения. Том 3 / К.А. Тимирязев. - М.: Госсельхозиздат, 1937. - 452 с.

7. Шеуджен, А.Х. Агрохимия. Часть 2. Методика агрохимических исследований / А.Х. Шеуджен, Т.Н. Бондарева. Краснодар: КубГАУ, 2015. - 703 с.

8. Шеуджен, А.Х. Влияние микроэлементов на коэффициенты использования рисом азота, фосфора, калия удобрений / А.Х. Шеуджен, Т.Б. Логвина // Химизация сельского хозяйства. - 1991. - № 12. - С. 44 - 46.

9. Шеуджен, А.Х. Агрохимия микроэлементов в рисоводстве / А.Х. Шеуджен, Е.М. Харитонов, Х.Д. Хурум, Т.Н. Бондарева. - Майкоп: «Афиша», 2006. - 248 с.

10. Шеуджен, А.Х. Агрохимия и физиология питания риса / А.Х. Шеуджен. - Майкоп: ГУРИПП «Адыгея», 2005. 1012 c.

11. Шеуджен, А.Х. Теория и практика применения микро и ультрамикроудобрений в рисоводстве / А.Х. Шеуджен. - Майкоп: «Полиграф - ЮГ», 2016. - 380 с.

12. Школьник, М.Я. Микроэлементы в жизни растений / М.Я. Школьник. - Л.: Наука, 1974. - 324 с.

13. Ягодин, Б.А. Экологическая агрохимия / Б.А. Ягодин, Ю.П. Жуков, И. Кобзаренко // Агрохимия. - 2005. C. $566-574$.

14. Petrik, G.F. Analysis and assessment of the grain production sustainability / G.F. Petrik, A.G. Prudnikov // Annals of Agri Bio Research. - V. 24, I.2. - 2019. - P. 356 - 362.

15. Sheudzhen, A.K. Chemicals-based regulation of leaves-to-grains outflow of assimilates to enhance yields in rice (Oryza sativa L.) under conditions of its northern area / A.K. Sheudzhen, T.N. Bondareva, P.N. Kharchenko, I.A. Doroshev // Sel'skokhozyaistvennaya Biologya. - 54 (3). - 2019. - P. 512 - 527.

\section{REFERENCES}

1. Bityutskiy, N. P. Mineral Nutrition of plants / N.P. Bityutskiy. - SPb: Publishing house of St-Petersburg university. 2014. - 540 p.

2. Viliams, V.R. General agriculture with the basics of soil science / V.R. Viliams. - M.: «Novyy agronom». 1931. - 376 p.

3. Zhurbitskiy, Z.I. Physiological and agrochemical bases of applying fertilizers/ Z.I. Zhurbitskiy. - M.: Izd-vo AN SSSR. 1963. -294 p.

4. Kurkayev, V.T. Agrochemistry / V.T. Kurkayev. A.Kh. Sheudzhen. - Maykop: GURIPP «Adygeya». 2000. - 552 p. 
5. Pryanishnikov, D.N. Selected works. Vol. 1 / D.N. Pryanishnikov. - M.: Selkhozizdat. 1952. - 692 p.

6. Timiryazev, K.A. Selected works. Vol. 3 / K.A. Timiryazev. - M.: Gosselkhozizdat. 1937. - 452 p.

7. Sheudzhen, A.Kh. Agrochemistry. Part 2. Methods of agrochemical research/ A.Kh. Sheudzhen. T.N. Bondareva. Krasnodar: KubSAU. 2015. - 703 p.

8. Sheudzhen, A.Kh. Influence of microelements on the utilization rates of nitrogen, phosphorus, potassium fertilizers by rice plants/ A.Kh. Sheudzhen. T.B. Logvina // Chemicalization of agriculture. 1991. № 12. p. 44-46.

9. Sheudzhen, A.Kh. Agrochemistry of microelements in rice growing / A.Kh. Sheudzhen. E.M. Kharitonov. Kh.D. Khurum. T.N. Bondareva. - Maykop: «Afisha». 2006. - 248 p.

10. Sheudzhen, A.Kh. Agrochemistry and physiology of rice nutrition / A.Kh. Sheudzhen. - Maykop: GURIPP «Adygeya». 2005. - $1012 \mathrm{p}$.

11. Sheudzhen, A.Kh. Theory and practice of using micro- and ultramicrofertilizers in rice growing / A.Kh. Sheudzhen. Maykop: «Poligraf - YuG». 2016. - 380 p.

12. Shkolnik, M.Ya. Microelemnets in life of plants / M.Ya. Shkolnik. - L.: Nauka. 1974. - 324 p.

13. Yagodin, B.A. Ecological agrochemistry / B.A. Yagodin. Yu.P. Zhukov. I. Kobzarenko // Agrokhimiya. - 2002. - P. 566574.

14. Petrik, G.F. Analysis and assessment of the grain production sustainability / G.F. Petrik, A.G. Prudnikov // Annals of Agri Bio Research. - V. 24, I.2. - 2019. - P. 356 - 362.

15. Sheudzhen, A.K. Chemicals-based regulation of leaves-to-grains outflow of assimilates to enhance yields in rice (Oryza sativa L.) under conditions of its northern area / A.K. Sheudzhen, T.N. Bondareva, P.N. Kharchenko, I.A. Doroshev // Sel'skokhozyaistvennaya Biologya. - 54 (3). - 2019. - P. 512 - 527.

\section{Асхад Хазретович Шеуджен}

Заведующий отделом прецизионных технологий ФГБНУ «ФНЦ риса», заведующий кафедрой агрохимии Кубанского ГАУ им. И.Т. Трубилина

E-mail: a_kh_sheudjen@mail.ru

\section{Татьяна Николаевна Бондарева}

Ведущий научный сотрудник отдела прецизионных технологий ФГБНУ «ФНЦ риса», доцент кафедры агрохимии Кубанского ГАУ им. И.Т. Трубилина

E-mail: bondarevatatjna@mail.ru

\section{Ярослав Богданович Петрик}

аспирант Кубанского ГАУ

им. И.Т. Трубилина

ФГБНУ «ФНЦ риса»

350921, г. Краснодар, пос. Белозерный, 3

E-mail: arrri_cub@mail.ru

ФГБОУ ВО «Кубанский государственный аграрный университет им. И.Т. Трубилина», 350044, г. Краснодар, ул. Калинина, 13

\section{Askhad Khazretovich Sheudzen}

Head of precise technologies department, FSBSI Federal Scientific Rice Centre,

Head of agrochemistry department, KubSAU

named after I.T. Trubilin

E-mail: a_kh_sheudjen@mail.ru

\section{Tatyana Nikolaevna Bondareva}

Leading researcher of precise technologies department, FSBSI Federal Scientific Rice Centre, associate professor of agrochemistry department, KubSAU named after I.T. Trubilin

E-mail: bondarevatatjna@mail.ru

\section{Yaroslav Bogdanovich Petric,} Post-graduate student, KubSAU named after I.T. Trubilin

FSBSI Federal Scientific Rice Centre 3, Belozerniy, Krasnodar, 350921, Russia E-mail: arri_cub@mail.ru

FSBEl of HE «Kuban State Agrarian University named after I.T. Trubilin» 13, Kalinina st., Krasnodar, 350044, Russia 


\section{ОСОБЕННОСТИ НАКОПЛЕНИЯ КАДМИЯ И СЕЛЕНА РАСТЕНИЯМИ РИСА ПРИ РАЗНЫХ СРОКАХ ПОСАДКИ (ПОСЕВА)}

Синергетические эффекты таких микроэлементов как селен (Se) и кадмий (Cd) хорошо известны. Однако особенности накопления растениями данных микроэлементов являются предметом обсуждения в научном сообществе. В данной статье исследуется влияние температуры на накопление микроэлементов в двух разных средах. Селен и кадмий применяли в трех вариантах $\left(T_{0}-0: 0 ; T_{1}-0,4: 1 ; T_{2}-1: 2\right)$ мг/кг. Срок посадки и количество тепла, потребляемого культурой для достижения физиологической зрелости, были разными. Солнечный свет может являться важным фактором, влияющим на накопление растением тяжелых металлов. Результаты исследования показали, что структура накопления обоих элементов может отличаться в одном и том же материале. Повышение количества удобрений в почве линейно увеличивало и содержание металлов в зерне риса. Изучение различных частей растений показало, что метелка является основным резервуаром накопления Se и Cd. Растения с более ранним сроком посадки накапливают больше селена, в то время как растения, высаженные месяцем позже, поглощают больше кадмия. Растения проходят основные фазы вегетации: кущение, колошение и цветение в течение 20-30 дней в зависимости от сорта. Но растения с поздним сроком посадки завершают эти фазы в течение 9-10 дней, что в конечном итоге приводит к меньшему поглощению тепла. Эти быстрые переходные изменения могут привести к накоплению большого количества Cd в зерне риса даже при низком его уровне (1 и 2 мг/кг), что делает рис небезопасным для использования в пищевых целях. Установление оптимального срока высадки рассады и впоследствии использование в технологии выращивания риса может стать способом снижения поступления Se и $\mathrm{Cd}$ в растения риса.

Ключевые слова: антагонизм, кадмий, селен, тенденция к накоплению, вегетационный период, рис, обогащенный селеном, риск для здоровья.

\section{THE PARADOX IN ACCUMULATION BEHAVIOR OF CADMIUM AND SELENIUM AT DIFFERENT PLANTING TIMES IN RICE}

The synergistic effects of trace elements selenium (Se) and cadmium (Cd) are well known. But the reasons for the trending accumulation behavior in both trace elements are under debate in the scientific community. The present investigation was conducted to evaluate the impact of heat units on the accumulation behavior in two environments. Se and Cd were applied in three groups $\left(T_{0} ; 0: 0, T_{1} ; 0.4: 1, T_{2} ; 1: 2\right) \mathrm{mg} / \mathrm{kg}^{-1}$. As the time of planting and heat units consumed by the crop to attain its physiological maturity appears to be different. The sunlight may contribute as an important manipulating factor for the accumulation of heavy metals in the plant. The results of the present study indicated that the behavior in the accumulation pattern of both elements appears to be distinct in the same material. The increased fertilizer treatment in soil bulk linearly increased the metal contents in rice grain. The studies between different plant parts disclosed panicle as the primary reservoir for Se and Cd accumulation. The plant sown earlier accumulates more Se than $\mathrm{Cd}$ while the plants uptake more Cd when sown 1 month later. The plant completes the critical developmental phases (tillering, heading, and flowering) within 20-30 days interval depending on the variety. But the late-sown plants complete these transitional phases within 9-10 days interval ultimately result in less utilization of heat units. These quick transitional changes may lead to the uptake of an ample amount of $\mathrm{Cd}$ contents in rice grain even at a low level of Cd stress (1 and $2 \mathrm{mg} \mathrm{kg}^{-1}$ ), making rice unsafe for edible purposes. The proper time of planting could be effective in timely acclimatization of Se and Cd sequestration and translocation in rice various components.

Keywords: antagonism, cadmium, selenium, accumulation trend, growth period, Se-enriched rice, health risks.

\section{Введение}

Рис (Oryza sativa L) является основным продуктом питания для половины населения Земли. Для повышения технологических и пищевых качеств зерна, научное сообщество постоянно работает над улучшением молекулярных, генетических и селекционных методов. Китай - одна из стран с максимальным потреблением и производством риса. Спрос на рис будет увеличиваться, поскольку к 2050 году насе- ление планеты достигнет 9,15 миллиардов человек. Для удовлетворения продовольственных потребностей населения, в последние годы проводится биообогащение основных продовольственных культур полезными питательными веществами и микроэлементами. Технологический прогресс последних лет поменял отношение людей к потреблению риса с количественного на качественное. Кроме того, устойчивое и значительное влияние международных 
стандартов качества на внутренний рынок приведет к смещению производства риса с высокоурожайных сортов на высококачественные.

Растения можно биообогащать полезными микроэлементами, а загрязнители окружающей среды (почва, воздух и вода) могут быть обезврежены с помощью живых растений. Селен оказывает множество эффектов на рост и развитие растений, в том числе участвует в регуляции фотосинтеза и дыхания растений, уменьшая повреждение растений свободными радикалами и токсическое действие тяжелых металлов. Он также увеличивает способность растений противостоять стрессу. У разных видов растений есть большие различия в поглощении и накоплении селена. Крестоцветные растения обладают относительно сильной способностью к накоплению селена, за ними следуют бобовые, затем злаки.

Имеются большие территории с почвами, загрязненными кадмием, вследстви выбросов промышленных предприятий. При выращивании риса на таких почвах в зерне накапливается кадмий , что может стать потенциальным источником его поступления в пищевую цепь. В Японии (1950-е годы) люди страдали от болезни Итай-итай (потеря кальция в костях, анемия и сильные мышечные боли) из-за выращивания риса в загрязненной кадмием промышленной воде. Несколько недавних исследований показало, что Se оказывает значительный антагонистический эффект на абсорбцию растениями риса токсичных тяжелых металлов, включая ртуть $(\mathrm{Hg})$, мышьяк (As), сурьму (Sb) и кадмий (Cd). Следовательно, биообогащенние риса селеном можно использовать как способ снижения токсичности кадмия (Lin et al. 2012) и как источник регенерации почвы.

Разнообразные климатические и абиотические факторы могут изменить нормальное функционирование сельскохозяйственных культур. Многие белки и измененные метаболические пути могут активироваться при внезапном изменении температуры. Кроме того, взаимодействие генотип × среда влия- ет на урожайность сельскохозяйственных культур. Всегда требуются усилия для повышения урожайности основных полевых культур. Селекция скороспелых сортов поможет повысить урожайность. Влияние преждевременной и динамичной тепловой энергии на пищевой статус риса недостаточно изучено.

\section{Цель исследований}

Оценить влияние тепловых единиц на тенденцию поглощения и накопления кадмия и селена при обычном и позднем сроках посева; оценить синергетический эффект селена на смягчение последствий и токсичность кадмия; оценить особенности накопления микроэлементов в различных частях растения риса (стебель, листья, метелка, шелуха, соломина, рисовые отруби, зародыш и эндосперм) и изучить эффективность раздельного внесения селеносодержащих удобрений на рост риса и поглощение кадмия. Таким образом, двумя основными проблемами, на которые следует обратить внимание, стали восстановление почвы и сокращение накопления тяжелых металлов в шлифованном рисе; обе требуют лучшего понимания накопления и перемещения тяжелых металлов в растениях риса.

\section{Материалы и методы}

Рисовая почва (0-20 см) была отобрана в пяти местах исследовательской зоны Научно-исследовательского института риса, Сычуаньский сельскохозяйственный университет, Вэньцзян, Чэнду, Китайская Народная Республика, 103,8253 восточной долготы, $30,70254^{\circ}$ северной широты, высота 497 м над уровнем моря. Образцы почвы тщательно перемешивали в композиционную смесь для оценки основных физико-химических свойств исследуемой почвы (табл. 1). Почва (10 кг) была помещена в пластиковые сосуды размером $28 \mathrm{~cm} \times 35$ см×10 см. Рис с высоким содержанием селена был предоставлен демонстрационной базой международного научно-технического сотрудничества провинции Сычуань. Материал высевали в 2 срока с разницей в 1 месяц.

Таблица 1. Основные физико-химические свойства изучаемой почвы

\begin{tabular}{|l|c|}
\hline \multicolumn{1}{|c|}{ Показатель } & Содержание (мг/кг сухой почвы) \\
\hline $\mathrm{pH}$ & 5,98 \\
\hline $\mathrm{OB}$ & 32870 \\
\hline Общий N & 172 \\
\hline Общий P & 1960 \\
\hline Общий Se & 0,3242 \\
\hline Общий Cd & 0,0912 \\
\hline
\end{tabular}

Примечание: ОВ - органическое вещество, N- азот, P-фосфор, Se - селен, Cd - кадмий

Условия выращивания. Питомник был заложен в естественных полевых условиях в период вегетации риса в Вэньцзяне. Все условия (орошение, рыхление, внесение удобрений, прополка), необходимые для нормального роста риса, поддерживались до тех пор, пока растения не достигли фазы 2-х листьев, примерно через 40 дней после посева. Затем рас- тения пересаживали в сосуды, по 3 на сосуд, чтобы сохранить повторности для получения надежных данных. Предполагалось, что растения должны укорениться через неделю после пересадки, затем в сосуды был внесен экзогенный питательный раствор. Чтобы избежать образования димеров и обеспечить легкую доступность микроэлементов для растений 
элементы вносили в разное время: кадмий - через 7 дней после пересадки, селен - 14 дней. Были приняты меры предосторожности, чтобы гарантировать отсутствие помех от дождя в течение 48 часов до и после внесения питательного раствора. Растения убирали при достижении фазы полной спелости зерна. Уровень воды в сосудах поддерживался на 5 см на протяжении всего вегетационного периода.

Химикаты. Стандартный раствор Se был предоставлен Национальным центром анализа и испытаний цветных металлов и электронных материалов. Использовали химические соединения $\left(\mathrm{Na}_{2} \mathrm{SeO}_{3}\right.$ для $\mathrm{Se}$ и $\mathrm{CdCl}_{2} \cdot 2 \frac{1}{2} \mathrm{H}_{2} \mathrm{O}$ для $\mathrm{Cd}$ ); азотная кислота, хлорная кислота и соляная кислота были гарантированными реагентами; эти реагенты были закуплены у Ruijingte Chemistry Company, Чэнду, Китай.

Расчеты питательных веществ были сделаны для:

1. Расчета доступного количества рассматриваемого элемента питания в молекулярной формуле соответствующего исходного химического соединения;

2. Оценки количества $\mathrm{Cd}$ и $\mathrm{Se}$, необходимого на емкость;

3. Оценки количества химикатов, необходимых для приготовления исходных растворов на весь эксперимент.

Содержание селена в $\mathrm{Na}_{2} \mathrm{SeO}_{3}$. Селен, используемый в опыте, представлял собой селенит натрия $\left(\mathrm{Na}_{2} \mathrm{SeO}_{3}\right)$. Атомная масса Se составляет 78,91, а молекулярная масса $\mathrm{Na}_{2} \mathrm{SeO}_{3}$ - 172,94. Следовательно, используя формулу, мы вычислили содержание Se:

Содержание селена в соединении:

атомная масса $\mathrm{Se}$ $\cdot 100$ молекулярная масса соединения

Содержание $\mathrm{Se}$ в 1 г $\mathrm{Na}_{2} \mathrm{SeO}_{3}$ составляло 456 мг, нам была необходима концентрация Se в 1 мл раствора. Таким образом, мы добавили $1 г \mathrm{Na}_{2} \mathrm{SeO}_{3}$ (456 мг Se) к 456 мл дистиллированной воды, чтобы достичь цели 1 мг Se / мл.

Содержание кадмия в $\mathrm{CdCl}_{2} \cdot 2 \frac{1}{2} \mathrm{H}_{2} \mathrm{O}$. Кадмий, используемый в настоящем опыте, представлял собой сложное соединение $\left(\mathrm{CdCl}_{2} \cdot 2 \frac{1}{2} \mathrm{H}_{2} \mathrm{O}\right)$. Атомная масса Cd равна 112,40, а атомный номер 48. Молекулярная масса $\mathrm{CdCl}_{2} \cdot 2 \frac{1}{2} \mathrm{H}_{2} \mathrm{O}$ составляет 228,35. Следовательно, мы рассчитали содержание Cd по формуле:

Содержание кадмия в соединении:

атомная масса $\mathrm{Cd}$ молекулярная масса соединения $\cdot 100$

Содержание $\mathrm{Cd}$ в 1 г $\mathrm{CdCl}_{2} \cdot 2 \frac{1}{2} \mathrm{H}_{2} \mathrm{O}$ составило 490 мг. Нам была необходима концентрация Cd 1 мг в 1 мл раствора. Таким образом, мы добавили 1 г $\mathrm{CdCl}_{2} \cdot 2 \frac{1}{2} \mathrm{H}_{2} \mathrm{O}(490$ мг Cd) к 490 мл дистиллированной воды для достижения цели 1 мг Cd/мл. Затем была рассчитана концентрация для 10 кг почвы, используемой в опыте (табл. 2).

Таблица 2. Варианты обработок, используемых в опыте

\begin{tabular}{|l|c|c|c|}
\hline \multicolumn{1}{|c|}{ Вариант } & $\begin{array}{c}\mathbf{N a}_{2} \mathbf{S e O}_{3} \\
\text { (мг/кг }\end{array}$ & $\begin{array}{c}\mathbf{C d C l}_{2} \cdot \mathbf{2} \mathbf{1} / \mathbf{\mathbf { H } _ { 2 } \mathbf { O }} \\
\text { сухой почвы) }\end{array}$ & Примечание \\
\hline $\mathrm{T}_{0}-$ контроль & - & - & без обработки \\
\hline Вариант 1 $\left(\mathrm{T}_{1}\right)$ & 0,4 & 1 & средний уровень стресса \\
\hline Вариант 2 $\left(\mathrm{T}_{2}\right)$ & 1 & 2 & высокий уровень стресса \\
\hline
\end{tabular}

Обработка данных. Сосуды были размещены в открытом поле с использованием рандомизированного полноблочного дизайна (RCBD) для полной оценки интерактивного влияния факторов окружающей среды на питательный статус риса. При достижении физиологической спелости отбирали по три растения на экспериментальную единицу и регистрировали данные.

Определение градусо-дней (тепловых единиц). Градусо-дни - это общее количество тепловых единиц, потребляемых культурой при достижении зрелости. Стадии развития растения регистрировались в подходящее время, чтобы оценить влияние факторов окружающей среды (особенно тепловых единиц) на питательный статус риса. Сроки регистрировались для морфологически различных стадий (кущение, 50 \% колошение, цветение, 50 \% спелости, полная спелость и сбор урожая), а единицы тепла, потребляемые сортами риса для достижения соответствующей стадии, оценивались с использованием формулы с небольшими доработками.
Тепловая единица:

$\frac{\text { макс. суточная } t^{\circ}-\text { мин. суточная } t^{\circ}}{2}-$ базовая $t^{\circ}$.

Температура измерялась в градусах Цельсия ( $\left.{ }^{\circ} \mathrm{C}\right)$, базовая температура была установлена на $10^{\circ} \mathrm{C}$.

Элементный анализ. Элементный анализ был проведен для изучения мобилизации и накопления кадмия и селена в растениях риса. Все гидролизаты и экстракты анализировали с помощью двухканального атомно-флуоресцентного анализатора (RGF-6800, Bo Hui Co., Ltd, Пекин, Китай) для определения содержания Se (GB-5009.93-2017). Для определения содержания Cd использовался атомно-абсорбционный спектрофотометр (ICE-3300, Thermo, USA) (GB-5009.15-2014). Подготовку к анализу стеблей, листьев и частей метелки проводили по методу, описанномy Liang et al. (2018). Образцы растений высушивали, взвешивали $(0,1$ г), помещали в стеклянный сосуд, а затем озоляли в 15 мл диоксидного раствора $\mathrm{HNO}_{3}: \mathrm{HClO}_{4}(9: 1, \mathrm{v} / \mathrm{v})$ при температуре $190{ }^{\circ} \mathrm{C}$ на 
электрической плитке (EH20A Plus, Labtech, США) до тех пор, пока раствор не принимал белый оттенок.

Затем раствор упаривали до 1 мл. Ионы Se на этом уровне было необходимо перевести с $\mathrm{Se}^{6+}$ до $\mathrm{Se}^{4+}$, чтобы получить общее содержание $\mathrm{Se}\left(\mathrm{Bce} \mathrm{Se}^{4+}\right)$ в вываренных образцах.

Определение общего селена. Затем расщепленные образцы разбавляли 5 мл раствора $\mathrm{HCl}: \mathrm{H}_{2} \mathrm{O}$ $(1: 1, \mathrm{v} / \mathrm{v})$, чтобы снизить $\mathrm{Se}^{6+}$ до $\mathrm{Se}^{4+}$ для определения общего Se. Раствор снова нагревали при 160 ${ }^{\circ} \mathrm{C}$ до тех пор, пока он не приобретал белый оттенок. Затем раствор трижды разбавляли 5 \% раствором $\mathrm{HCl}$ и фильтровали через мембранную фильтровальную бумагу 0,02 мкм, чтобы сохранить конечный объем 10 мл в центрифужных пробирках на 15 мл. Конечный профильтрованный раствор анализировали с помощью двухканального атомно-флуоресцентного анализатора (RGF-6800).

Настройки параметров RGF-6800. Параметр задавался следующим образом: высокое отрицательное напряжение - 340 B; ток лампы 100 мА; температура распыления $800^{\circ} \mathrm{C}$; высокая топка, 8 мм; расход газа-носителя 500 мл/мин; расход защитного газа 1000 мл/мин; методы измерения, стандартная кривая; чтение, площадь пика; время задержки, 1 с; время чтения 15 с; время зарядки 8 с; размер пробы 2 мл. Содержание селена (мг/кг) рассчитывали по следующей формуле:

Содержание Se:

$$
\frac{(C-C O) \cdot V \cdot 1000}{m \cdot 1000 \cdot 1000}
$$

где $C$ - измеренная в образце концентрация раствора (нг/мл); СО - концентрация пустой контрольной группы (нг/мл); $m$ - масса образцов; $V$ - общий объем раствора.

Определение кадмия. Процесс разбавления раствором $\mathrm{HCl}: \mathrm{H}_{2} \mathrm{O}$ был опущен. Выпаренный раствор объемом 1 мл разбавляли в три раза 5 \% раствором $\mathrm{HCl}$ и фильтровали через мембранную фильтровальную бумагу 0,02 мкм для сохранения конечного объема 10 мл в центрифужных пробирках на 15 мл. Конечный профильтрованный раствор был проанализирован (ICE-3300, Thermo, США).

Параметры ICE-3300 и настройки лампы. Программное обеспечение Thermo Solaar (ICE-3300, Thermo, США) использовалось для анализа содержания кадмия в образце, настройки параметров были следующими: отрицательное высокое напряжение, 260 В; ток лампы 60 мА; температура золы $300{ }^{\circ} \mathrm{C}$; температура распыления $900^{\circ} \mathrm{C}$; высокая топка, 8 мм; расход газа-носителя 400 мл/мин; расход защитного газа 900 мл/мин; методы измерения, стандартная кривая; чтение, площадь пика; время задержки, 1 с; время чтения 15 с; время зарядки 8 с; размер пробы 1 мл.

Содержание Cd (мг/кг) рассчитывали по следующей формуле:
Содержание $\mathrm{Cd}$

$$
\frac{(C-C O) \cdot D \cdot V \cdot 1000}{m \cdot 1000 \cdot 1000}
$$

где $C$ - измеренная в образце концентрация раствора (нг/мл); СО - концентрация пустой контрольной группы (нг/мл); $D$ - коэффициент разбавления; $m$ масса образцов; $V$ - общий объем раствора.

Физиологические различия листьев. Зеленые листья срезали и помещали в 5 \% раствор $\mathrm{NaCl}$ на 4 часа для предотвращения резких осмотических изменений. Затем все листья были помещены на чистую белую бумагу и приклеены к ней при помощи прочной клейкой ленты. Для сравнения были выбраны разные листья на разных уровнях обработки, и влияние $\mathrm{Cd}$ и Se сравнили с контрольной группой (как в сосуде, так и в поле) с помощью MICROTEK scanMaker i800 Plus. pH почвы измеряли с помощью pH-метра (Accumet ${ }^{\oplus}$ AP115, США).

Статистический анализ. Для определения содержания элементов отбирали образцы с 2 растений для каждого компонента (стебля, листьев и частей метелки) использовали 2 биологических повтора. Данные о содержании Se и Cd были усреднены и указаны в таблицах как мг/кг. Программа Statistix 8.1 использовалась для оценки различий дисперсии (ANOVA). Для определения влияния, элементов и сортов на измеряемые параметры был применен план двухфакторного анализа (со всеми эффектами парного взаимодействия). Была определена наименьшая существенная разница (НСР) для сравнения средних значений с уровнем вероятности $95 \%$. Затем вычисляли уравнение линейной регрессии $y=a x+$ b для анализа корреляций с помощью Microsoft Excel 2016. Origin 8.0 использовался для графического представления данных.

\section{Результаты и обсуждение}

Культура риса является основным источником пищи во всем мире, и его преднамеренное биообогащение полезными микроэлементами может восполнить дефицит питательных веществ в рационе человека и животных. Стебель и листья растения можно использовать в качестве корма для животных. Следовательно, необходимо изучить особенности накопления селена и кадмия в различных частях растения (стебель, листья и метелка). Se хорошо известен антагонистическим влиянием против Cdиндуцированной токсичности растений. Данное исследование направлено на изучение особенностей накопления $\mathrm{Cd}$ и Se. Было изучено влияние тепловых единиц, чтобы привлечь внимание к физиологическому влиянию эпигенетических факторов на тенденцию накопления этих микроэлементов в растениях. Более того, был оценен оптимальный уровень удобрений, при котором выращивание культуры будет безопасным для здоровья, и в то же время полезным для мелиорации почвы.

Тенденция к увеличению накопления Se и Cd наблюдалась при повышенном уровне удобрений $\left(T_{1}, T_{2}\right)$ 
как при обычных, так и при поздних сроках посева (табл. 3). Было обнаружено, что метелки накапливают максимальное содержание обоих элементов, служа их основным резервуаром в период созревания. Поведение стебля и листьев оказалось различным. Листья были более чувствительны к накоплению селена, в то время как в стебле было обнаружено повышенное содержание кадмия. Исследования показали, что экзогенное применение полезных микроэлементов может значительно улучшить пищевой статус и физиологические функции растений. Накопление $\mathrm{Cd}$ и Se в эндосперме при обработке 1 (Se: 0,4 мг/кг и Cd: 1 мг/кг) не достигло токсичного уровня, рис можно использовать в пищевых целях (при стандартном и позднем посеве) после перера- ботки. Похоже, что применение селена в дозе 0,4 мг/ кг значительно снижает токсичность кадмия в эндосперме до 1 мг/кг, в то время как более высокие уровни обработки $\left(\mathrm{T}_{2}\right)$ увеличивают содержание как кадмия, так и селена сверх допустимых пределов, вызывая гипераккумуляцию этих элементов в рисе. Листья и стебли групп $\mathrm{T}_{0}$ и $\mathrm{T}_{1}$ показали поглощение элементов в безопасном диапазоне и могут использоваться в качестве корма для животных и удобрения почв (табл. 3). Обработка Cd вызывает некоторые физиологические повреждения листьев риса. Поражение листьев ржавчиной наблюдалась при большом внесении $\mathrm{Cd}$ и $\mathrm{Se}-2$ мг/кг и 1 мгкг соответственно (рис. 1). Контрольная группа не показала признаков стресса у растений риса.

Таблица 3. Содержание селена и кадмия в растениях риса при стандартном и позднем сроках посева

\begin{tabular}{|c|c|c|c|c|c|c|c|c|c|c|c|c|}
\hline \multirow{3}{*}{ Часть растения } & \multicolumn{4}{|c|}{ Контроль ( $\left.\mathbf{T}_{0}\right)$} & \multicolumn{4}{|c|}{ Обработка 1 ( $\left.\mathrm{T}_{1}\right)$} & \multicolumn{4}{|c|}{ Обработка 2 ( $\left.\mathrm{T}_{2}\right)$} \\
\hline & \multicolumn{2}{|c|}{$\begin{array}{c}\text { стандартный } \\
\text { посев }\end{array}$} & \multicolumn{2}{|c|}{$\begin{array}{c}\text { поздний } \\
\text { посев }\end{array}$} & \multicolumn{2}{|c|}{$\begin{array}{c}\text { стандартный } \\
\text { посев }\end{array}$} & \multicolumn{2}{|c|}{$\begin{array}{c}\text { поздний } \\
\text { посев }\end{array}$} & \multicolumn{2}{|c|}{$\begin{array}{c}\text { стандартный } \\
\text { посев }\end{array}$} & \multicolumn{2}{|c|}{$\begin{array}{c}\text { поздний } \\
\text { посев }\end{array}$} \\
\hline & Se & Cd & $\mathrm{Se}$ & Cd & $\mathrm{Se}$ & Cd & $\mathrm{Se}$ & Cd & $\mathrm{Se}$ & Cd & $\mathrm{Se}$ & Cd \\
\hline Стебель & 0,107 & 0,078 & 0,098 & 0,215 & 0,169 & 0,154 & 0,13 & 0,414 & 2,239 & 0,287 & 1,136 & 0,369 \\
\hline Листья & 0,115 & 0,043 & 0,215 & 0,145 & 0,755 & 0,112 & 0,341 & 0,235 & 3,603 & 0,248 & 1,270 & 0,382 \\
\hline Метелка & 1,033 & 0,385 & 0,627 & 0,786 & 1,410 & 0,556 & 0,40 & 1,542 & 7,995 & 0,837 & 3,804 & 1,716 \\
\hline Веточки метелки & 0,287 & 0,125 & 0,112 & 0,194 & 0,427 & 0,148 & 0,102 & 0,288 & 1,289 & 0,215 & 0,484 & 0,277 \\
\hline Лузга & 0,213 & 0,112 & 0,248 & 0,214 & 0,304 & 0,141 & 0,113 & 0,321 & 2,974 & 0,114 & 0,453 & 0,298 \\
\hline Мучка & 0,251 & 0,062 & 0,142 & 0,226 & 0,412 & 0,109 & 0,242 & 0,415 & 2,316 & 0,210 & 0,874 & 0,362 \\
\hline Зародыш & 0,178 & 0,043 & 0,084 & 0,098 & 0,115 & 0,09 & 0,196 & 0,346 & 1,136 & 0,162 & 1,369 & 0,318 \\
\hline Эндосперм & 0,103 & 0,044 & 0,041 & 0,054 & 0,152 & 0,068 & 0,091 & 0,172 & 0,279 & 0,136 & 0,624 & 0,461 \\
\hline $\begin{array}{l}\text { Общее } \\
\text { содержание } \\
\text { металлов }\end{array}$ & 1,255 & 0,506 & 0,940 & 1,146 & 2,334 & 0,822 & 1,211 & 2,191 & 13,837 & 1,372 & 6,267 & 2,467 \\
\hline
\end{tabular}

Примечание: $T_{0}$ - естественные почвенные условия; $T_{1}-\mathrm{Se}-0,4 \mathrm{Mr} / \mathrm{K}, \mathrm{Cd}-1 \mathrm{Mr} / \mathrm{k} \Gamma ; T_{2}-\mathrm{Se}-1 \mathrm{Mr} / \mathrm{k} \Gamma, \mathrm{Cd}-2 \mathrm{Mг} / \mathrm{Kr}$

Было обнаружено, что метелки поглощают максимальное количество Se и Cd, при созревании как при стандартных, так и при поздних сроках посева (посадки) (табл. 4). Чтобы исследовать каждый компонент метелки, мы отделили от нее зерна и изучили веточки. После этого зерно разделили на 4 компонента: лузгу (цветковые чешуи), поверхностные слои зерновки (перикарп и семенная оболочка), зародыш и эндосперм. Для каждого из них было определено содержание $\mathrm{Cd}$ и Se, затем было проведено сравнение между разными частями риса, чтобы установить взаимосвязь (табл. 3, рис. 2). Выявлено, что наибольшее количество селена и кадмия содержат рисовые отруби, шелуха и веточки метелки. В контроле содержание Se в зародыше и эндосперме, соответствовало национальному стандарту риса, обогащенного селеном, то есть 0,04-0,30 мг/к ${ }^{-1}$ (GB/T 22499-2008) при естественных почвенных условиях. В позднем посеве риса различия в накоплении кадмия были незначительными. Содержание кадмия в эндосперме было ниже допустимых стандартов

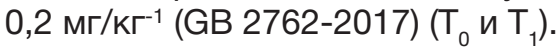

Сроки посадки сильно влияют на накопление кадмия при одинаковом его содержании в почве. Взаимодействие используемых удобрений, срока посева и поглощения элементов можно увидеть в таблице 4. Вред риса для здоровья увеличивался при повышенной дозе удобрений $\left(\mathrm{T}_{2}\right)$, поскольку содержание Se и Cd превышало стандарты. Чтобы снизить содержание Se и $\mathrm{Cd}$ до безопасного уровня, рекомендуется шлифовка риса. При позднем посеве и повышенной дозе удобрений $\left(T_{2}\right)$ в зерне накпливалось токсичное количество $\mathrm{Cd}$, что делало его опасным для для употребления в пищу. Результаты показали, что рис может выдерживать средний уровень стресса $\left(\mathrm{T}_{1}\right)$ и не накапливать в эндосперме и зародыше селена и кадмия в количестве превышающем безопасный уровень при своевременной высадке растений. 
Таблица 4. Дизайн двухфакторного анализа (взаимодействие всех возможных попарных комбинаций)

\begin{tabular}{|c|c|c|c|c|c|c|c|c|}
\hline $\begin{array}{c}\text { Взаимодей- } \\
\text { ствие }\end{array}$ & Стебель & Листья & Метелка & $\begin{array}{l}\text { Веточки } \\
\text { метелки }\end{array}$ & Лузга & Мучка & $\begin{array}{l}\text { Заро- } \\
\text { дыш }\end{array}$ & $\begin{array}{c}\text { Эн- } \\
\text { досперм }\end{array}$ \\
\hline \multicolumn{9}{|c|}{ Срок посева х стресс } \\
\hline$\Pi \mathrm{C} \times \mathrm{Se}$ & $0,454^{a}$ & $0,627^{a}$ & $1,723^{\text {ab }}$ & $0,232^{\mathrm{a}}$ & $0,271^{\mathrm{b}}$ & $0,419^{b}$ & $0,549^{a}$ & $0,252^{a}$ \\
\hline $\mathrm{CC} \times \mathrm{Se}$ & $0,838^{a}$ & $1,491^{a}$ & $3,479^{a}$ & $0,667^{a}$ & $1,163^{a}$ & $0.993^{a}$ & $0,476^{a}$ & $0,178^{a}$ \\
\hline$\Pi C \times C d$ & $0,173^{a}$ & $0,254^{b}$ & $1,348^{b}$ & $0,253^{a}$ & $0,277^{b}$ & $0,334^{b}$ & $0,254^{b}$ & $0,229^{b}$ \\
\hline $\mathrm{CC} \times \mathrm{Cd}$ & $0,333^{a}$ & $0,134^{c}$ & $0,593^{c}$ & $0,163^{\mathrm{a}}$ & $0,122^{\mathrm{c}}$ & $0,127^{c}$ & $0,098^{c}$ & $0,082^{c}$ \\
\hline \multicolumn{9}{|c|}{ Обработка х стресс } \\
\hline $\mathrm{T}_{0} \times \mathrm{Se}$ & $0,102^{b}$ & $0,165^{a}$ & $0,830^{\mathrm{b}}$ & $0,199^{b}$ & $0,230^{\mathrm{a}}$ & $1,595^{\mathrm{a}}$ & $0,131^{\mathrm{b}}$ & $0,072^{c}$ \\
\hline $\mathrm{T}_{0} \times \mathrm{Cd}$ & $0,146^{b}$ & $0,094^{c}$ & $0,585^{b}$ & $0,159^{b}$ & $0,163^{a}$ & $0,144^{a}$ & $0,071^{b}$ & $0,049^{c}$ \\
\hline $\mathrm{T}_{1} \times \mathrm{Se}$ & $0,149^{b}$ & $0,548^{\mathrm{a}}$ & $1,075^{\mathrm{ab}}$ & $0,264^{\mathrm{ab}}$ & $0,208^{a}$ & $0,327^{a}$ & $0,155^{b}$ & $0,122^{\mathrm{bc}}$ \\
\hline $\mathrm{T}_{1} \times \mathrm{Cd}$ & $0,284^{b}$ & $0,174^{b}$ & $1,049^{a b}$ & $0,218^{\mathrm{ab}}$ & $0,231^{a}$ & $0,262^{a}$ & $0,218^{b}$ & $0,120^{\mathrm{bc}}$ \\
\hline $\mathrm{T}_{2} \times \mathrm{Se}$ & $1,687^{a}$ & $2,465^{a}$ & $5,899^{a}$ & $0,886^{a}$ & $1,713^{a}$ & $0,196^{a}$ & $1,252^{\mathrm{a}}$ & $0,452^{a}$ \\
\hline $\mathrm{T}_{2} \times \mathrm{Cd}$ & $0,328^{b}$ & $0,315^{a}$ & $1,276^{\mathrm{ab}}$ & $0,159^{\mathrm{ab}}$ & $0,206^{a}$ & $0,286^{a}$ & $0,240^{b}$ & $0,298^{\mathrm{ab}}$ \\
\hline $\mathrm{CO}$ & 0,229 & 0,516 & 0,921 & 0,128 & 0,589 & 0,290 & 0,0566 & 0,037 \\
\hline $\mathrm{HCP}_{05}$ & 0,985 & 2,221 & 3,9636 & 0,554 & 2,5353 & 1,249 & 0,2435 & 0,162 \\
\hline \multicolumn{9}{|c|}{ Эффект взаимодействия } \\
\hline $\begin{array}{l}\text { Срок посева х } \\
\text { стресс }\end{array}$ & ns & * & * & $\mathrm{ns}$ & * & * & * & * \\
\hline $\begin{array}{l}\text { Обработка х } \\
\text { стресс }\end{array}$ & * & * & * & * & ns & ns & * & * \\
\hline
\end{tabular}

Примечание: ПС и СС обозначают поздний и стандартный срок посева соответственно, $T_{0}-0, T_{1}-(0,4+1), T_{2}-(1+2)$ обозначают мг Se + Cd на кг $\Gamma^{1}$. Значения, которые не имеют одинаковых букв в столбце, значительно различаются при $p \leq 0,05$; * обозначает значительные различия, ns - незначительные. CO - стандартная ошибка, НСР (0,05) - наименьшая существенная разница с уровнем вероятности 5 \%

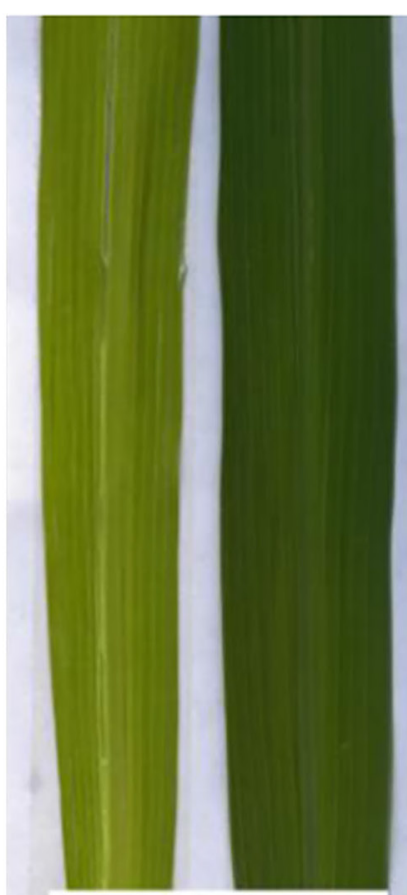

Field material Control

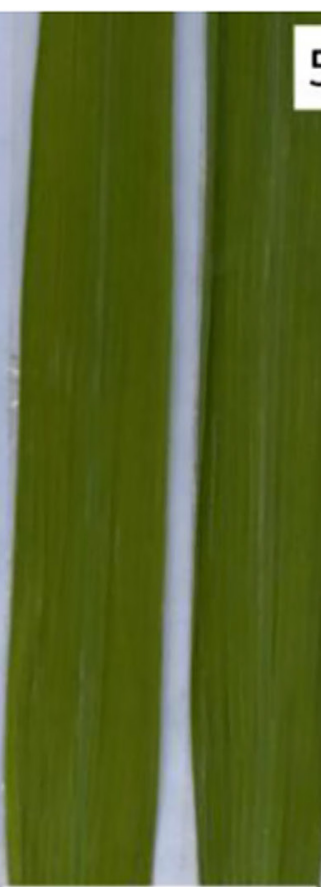

Pots material Control

\section{B}

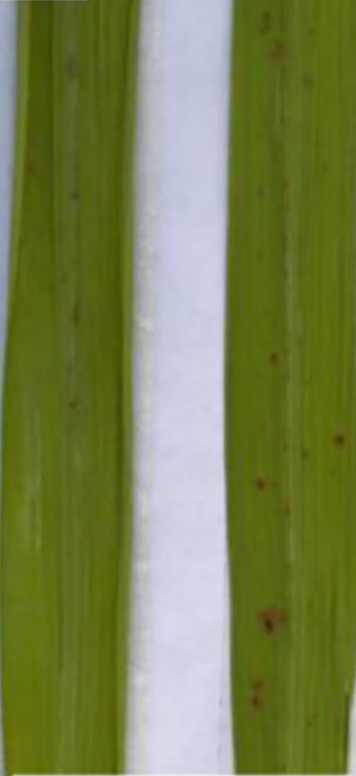

$\mathrm{Cd} 2 \mathrm{mg} / \mathrm{kg}+\mathrm{Se} 1 \mathrm{mg} / \mathrm{kg}$

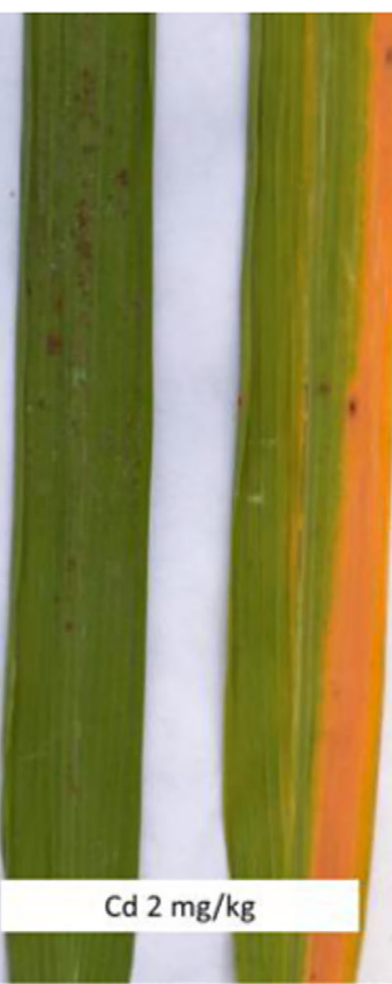

Рисунок 1. Видимые изменения при обработке селеном и кадмием 

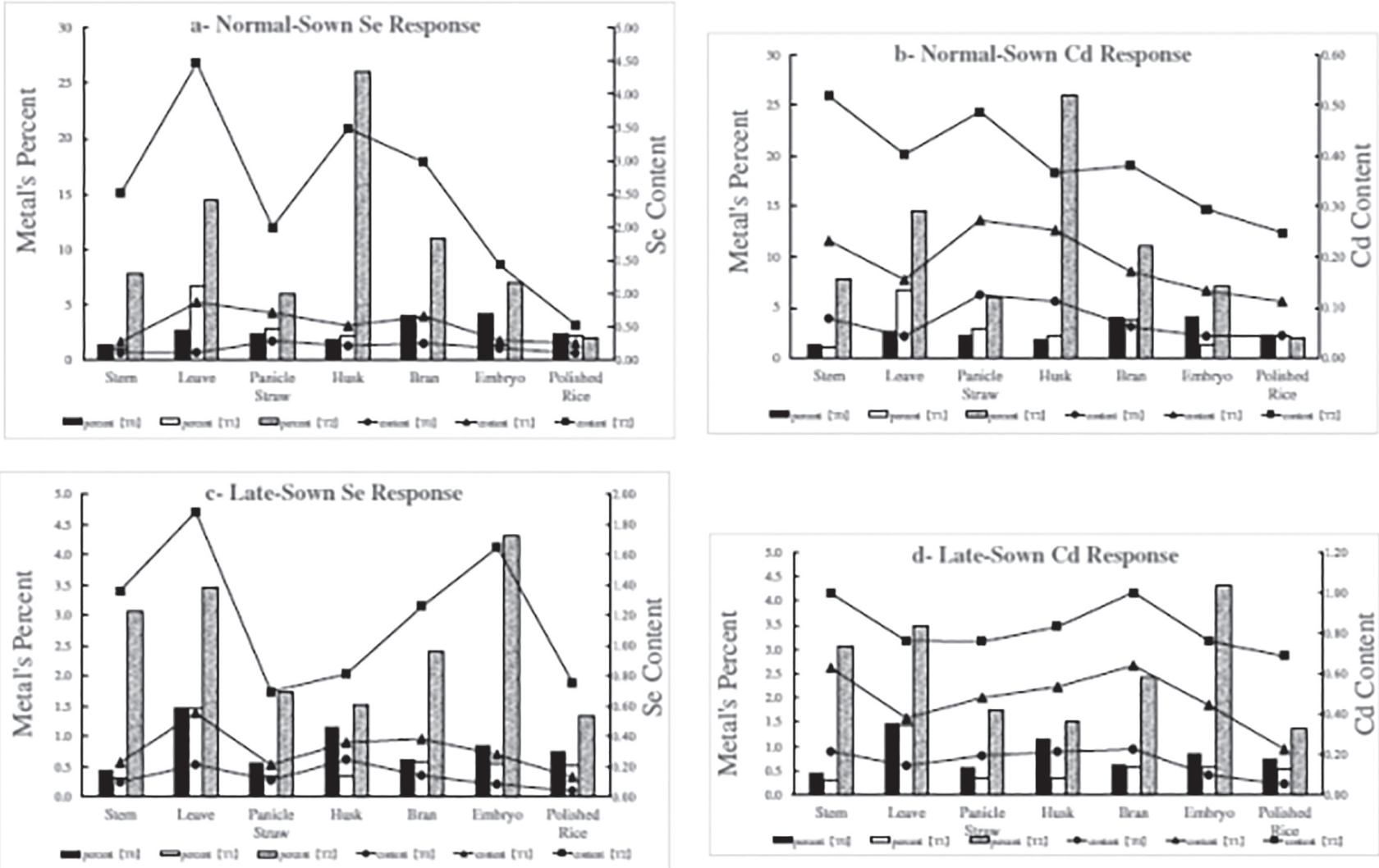

- процент ( $\left.T_{d}\right), \square-$ процент $\left(T_{1}\right), \square-$ процент $\left(T_{2}\right), \bullet-$ содержание $\left(T_{d}\right), \Delta$ - содержание $\left(T_{1}\right), \mathbf{-}-$ содержание $\left(T_{2}\right)$ Рисунок 2a - d. Сравнение поглощения рисом Se и $\mathrm{Cd}$ при разных уровнях обработки $\left(\mathrm{T}_{0}, \mathrm{~T}_{1}, \mathrm{~T}_{2}\right)$ и разных сроках посева (стандартный и поздний)

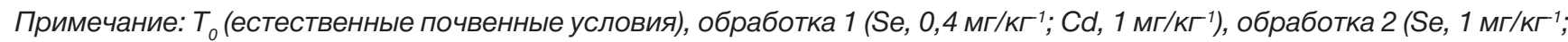

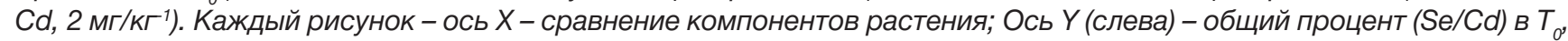
$T_{1}$ и $T_{2}$ (обозначен гистограммой); Ось Y (справа) - фактическое содержание Cd и Se накопленное в разных частях растения при $T_{0}, T_{1}$ и $T_{2}$ (обозначено линией тренда)

Таблица 5. Количество дней и тепловых единиц, необходимых рису для достижения определенной фазы

\begin{tabular}{|c|c|c|c|c|c|c|c|c|c|}
\hline Стадия & Посев & $\begin{array}{l}\text { Пере- } \\
\text { садка }\end{array}$ & $\begin{array}{l}\text { Стрес- } \\
\text { совая } \\
\text { обра- } \\
\text { ботка }\end{array}$ & $\begin{array}{l}\text { Куще- } \\
\text { ние }\end{array}$ & $\begin{array}{c}50 \% \\
\text { выметы- } \\
\text { вания }\end{array}$ & $\begin{array}{c}\text { Цвете- } \\
\text { ние }\end{array}$ & $\begin{array}{c}50 \% \\
\text { спело- } \\
\text { сти }\end{array}$ & $\begin{array}{c}\text { Cпе- } \\
\text { лость }\end{array}$ & Уборка \\
\hline $\begin{array}{l}\text { Дата при } \\
\text { стандарт- } \\
\text { ном посеве }\end{array}$ & 13.04 & 23.05 & 05.06 & 17.07 & 10.08 & 16.08 & 20.08 & 30.08 & 07.09 \\
\hline $\begin{array}{l}\text { Дата при } \\
\text { позднем } \\
\text { посеве }\end{array}$ & 12.05 & 02.06 & 27.06 & 12.08 & 17.08 & 21.08 & 29.08 & 09.09 & 14.09 \\
\hline \multirow{2}{*}{$\begin{array}{l}\text { Стандарт- } \\
\text { ный посев }\end{array}$} & Дни & 40 & 52 & 94 & 119 & 125 & 129 & 140 & 146 \\
\hline & $\begin{array}{l}\text { Тепловые } \\
\text { единицы }\end{array}$ & 408 & 575 & 1207 & 1651,5 & 1753 & 1818,5 & 1994 & 2068,5 \\
\hline \multirow{2}{*}{$\begin{array}{l}\text { Поздний } \\
\text { посев }\end{array}$} & Дни & 21 & 46 & 92 & 97 & 101 & 109 & 120 & 125 \\
\hline & $\begin{array}{c}\text { Тепловые } \\
\text { единицы }\end{array}$ & 189,5 & 489,5 & 1174 & 1258 & 1326 & 1469 & 1666,5 & 1753 \\
\hline
\end{tabular}

Как видно из таблицы 5, тепловые единицы, потребляемые рисом для достижения стадии кущения, не сильно различались при стандартном и позднем сроках посева и высадки растений. В то время как следующая переходная фаза (50 \% выметывания) в группе позднего посева обычно начинается намного раньше, чем в группе стандартного. Следовательно, количество потребляемых тепловых единиц не оди- 
наково для прохождения каждой фазы (табл. 5). Растения на позднем посеве получают меньше тепловых единиц для достижения своей физиологической зрелости, чем растения с посевом в стандартный срок. Количество тепловых единиц, израсходованных при позднем посеве, составило 1666,5 в период созревания и 1753 до уборки, в то время как растения, с посевов в стандартные сроки, потребляли такое же количество тепловых единиц при 50 \% выметывании и стадии цветения соответственно (табл. 5).

Ге и его коллеги определили влияние транспирации корней и листьев на поглощение Cd при разной температуре в период вегетации. Авторы установили, что повышение температуры способствует накоплению кадмия в побегах и корнях. Они пришли к выводу, что при потеплении может увеличиться площадь поверхности корня, его активные участки и уровень поглощения $\mathrm{Cd}$, а также увеличиться транспирация листьев; следовательно, повышенная транслокация Cd от корней к побегам может стать возможной. Однако при поздних сроках посева потепление может способствовать быстрым физиологическим изменениям в растении, и они завершают фазы своего развития быстрее. Следовательно, повышенное поглощение элементов из-за определенных физиологических изменений в растениях, вероятно, может проходить на уровне корней. Стрессовая обработка вызывала подкисление почвенного раствора, особенно в нижнем слое почвы (20 см) (табл. 6), что способствует интенсивному поглощению растениями кадмия.

Таблица 6. pH почвы при стрессовой обработке на разной глубине

\begin{tabular}{|l|c|c|}
\hline \multirow{2}{*}{ Вариант } & \multicolumn{2}{|c|}{ Глубина } \\
\cline { 2 - 3 } & $\mathbf{1 0} \mathbf{~ c m}$ & $\mathbf{2 0} \mathbf{~ c m}$ \\
\hline$T_{0}$ (контроль) & 5,86 & 6,21 \\
\hline$T_{1}$ & 5,54 & 6,35 \\
\hline$T_{2}$ & 5,23 & 5,63 \\
\hline
\end{tabular}

Примечание: $T_{0}$ - естественные почвенные условия; $T_{1}-\mathrm{Se}-0,4 \mathrm{Mr} / \mathrm{k} \Gamma^{-1}, \mathrm{Cd}-1 \mathrm{M} / \mathrm{k} \Gamma^{-1} ; T_{2}-\mathrm{Se}-1 \mathrm{Mг} / \mathrm{k} \Gamma^{-1}, \mathrm{Cd}-2 \mathrm{Mг} / \mathrm{k} \Gamma^{-1}$

Увеличение количества удобрений в почве линейно увеличивает содержание металла в рисовом зерне, о чем свидетельствует сильная линейная связь $\left(R_{2}=0,82: 0,99\right)$ от почвы к корням (рис. За) и от корней к нешелушенному рису (рис. 3b) соответственно. Аналогичные исследования, показавшие, что концентрация $\mathrm{Cd}$ в побегах растений линейно увеличивается с увеличением его содержания в почве, были проведены Peng et al. (2009). Растение риса интенсивно извлекает эти элементы из почвы и накапливают их в листьях и метелках. Максимальное количество кадмия и селена в метелках накапливается при достижении физиологической зрелости. Сравнение содержания Cd и Se в вегетативных opганах растения риса показало, что листья являются основным источником накопления Se при обоих сроках посева (стандартном и позднем), в то время как стебель служит основным хранилищем Cd (рис. 2). Когда уровень стресса повышается $\left(\mathrm{T}_{2}\right)$, содержание $\mathrm{Cd}$ и Se увеличивается во всех частях растений. Тенденция накопления кадмия смещается от вегетативных органов растения к репродуктивным при повышении уровня токсичности в группе позднего посева (табл. 4). В группе стандартного посева Se и Cd было больше в лузге , за ней следовали листья и мучка, но было обнаружено, что содержание $\mathrm{Se}$ было максимальным в листьях, за которыми следовали части метелки (цветковые чешуи и мучка) (рис. 2а). Больше всего Cd содержалось в стебле, затем следовали веточки метелки и рисовая мучка (рис. 2b).
Это может быть связано с активацией некоторых типов белков в растениях. Аналогичная тенденция оттока и выделения Cd наблюдалась в веточках метелки и стебле из-за активации дефенсин-подобного белка (CAL1). Противоположное поведение наблюдалось со смещением содержания Cd от вегетативных к репродуктивным органам растений, когда содержание металла наблюдались в группе позднего посева (рис. 2c, d). Было обнаружено, что содержание обоих элементов является максимальным в зародышах $\left(\mathrm{T}_{2}\right)$, затем следуют листья и стебли, в то время как содержание селена больше всего в листьях, затем следуют зародыш и стебель (рис. 2c). Однако соотношение $\mathrm{Cd}$ указывает на то, что рисовые мучка и стебли имеют почти одинаковое содержание $\mathrm{Cd}$ в них, затем следуют зародыш и эндосперм (рис. 2d). Это может быть связано с активацией чувствительных к окружающей среде генов, связанной с резкими переходными изменениями в росте растений, эффект которых увеличивался с повышением температуры на поздних стадиях репродукции. Эти быстрые изменения в развитии могут способствовать поступлению кадмия в рис, особенно в группе позднего посева. Похоже, что селен не оказывает синергетического эффекта на накопление кадмия при посеве в разные промежутки времени. Скорее подходящее время посева и адекватное использование тепловых единиц, помогают растению в изоляции кадмия и своевременнго использования и накопления селена. 

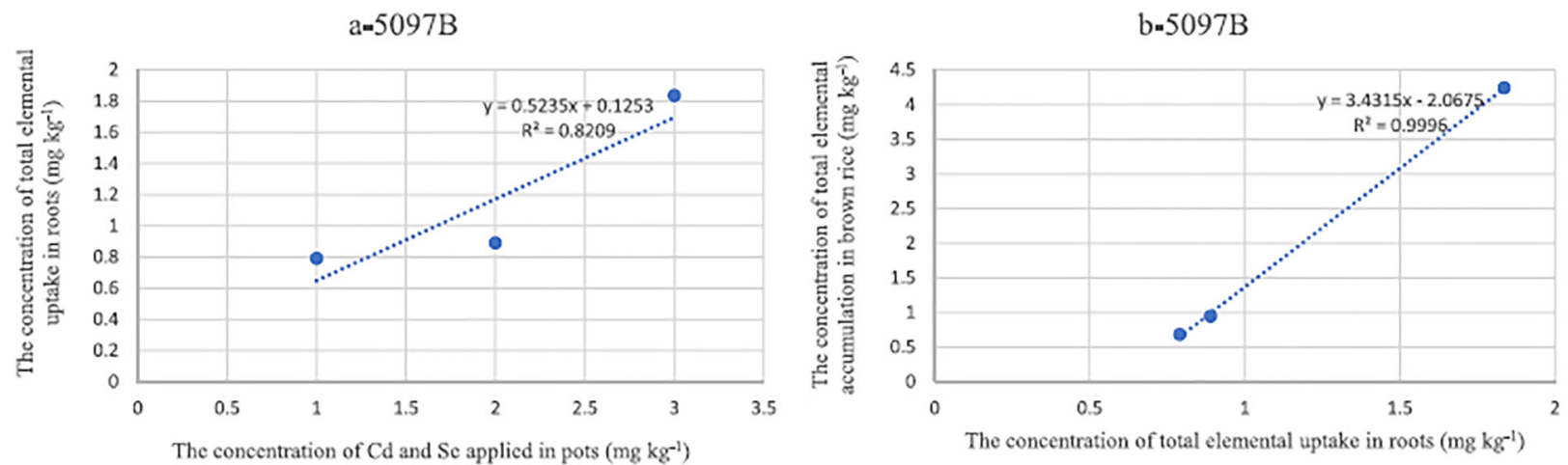

Рисунок За, b. Линейная связь между разными компонентами риса, обогащенного селеном (5097В)

Примечание: ось ОХ (слева) - Концентрация Cd и Se в сосудах (мг/кг); ось ОУ (слева) - Концентрация общего поглощения элементов корнями (мг/кг); ось ОХ (справа) - Концентрация общего поглощения элементов корнями (мг/кг), ось ОУ (справа) - Концентрация общего накопления элементов в нешлифованном рисе (мг/кг)

\section{Выводы}

Пространственно-временное воздействие солнечного света на экспрессионные изменения растения показало, что иммунный ответ и способность растения справляться с абиотическим стрессом (особенно с тяжелыми металлами) зависят от адекватного использования тепловых единиц и своевременной акклиматизации. Разное время посева может привести к различиям в накоплении металлов. Время посева может быть эффективным способом в секвестрации кадмия и его перемещении по флоэме. Многолокационные опыты и опыты с разным временем посева следует проводить в полевых условиях, чтобы полностью оценить манипуляционный эффект изменений на молекулярном уровне и другие эпигенетические эффекты на пищевой статус растений.

\section{Благодарность.}

Данная работа выполнена при поддержке Программы технологических исследований и разработок провинции Сычуань (2016 NZ 0106) и Международных проектов по сотрудничеству и обмену в области исследований и разработок провинции Сычуань (2018 НН 0016).

\section{ЛИТЕРАТУРА}

1. Alyemeni, M.N. Correction to: selenium mitigates cadmium-induced oxidative stress in tomato (Solanum lycopersicum L.) plants by modulating chlorophyll fluorescence, osmolyte accumulation, and antioxidant system / M.N. Alyemeni, M.A. Ahanger, L. Wijaya, P. Alam, R. Bhardwaj, P. Ahmad // Protoplasma. - 2018. - 255. - P. 985 - 986.

2. Boldrin, P.F. Soil and foliar application of selenium in rice biofortification / P.F. Boldrin, V. Faquin, S.J. Ramos, KVF Boldrin, F.W. Ávila, LRG Guilherme // J. Food Compos Anal. - 2013. - 31. - P. 238 - 244.

3. Broadley, M.R. Selenium biofortification of high-yielding winter wheat (Triticum aestivum L.) by liquid or granular Se fertilisation / M.R. Broadley, J. Alcock, J. Alford, P. Cartwright, I. Foot, S.J. Fairweather-Tait, D.J. Hart, R. Hurst, P. Knott, S.P. McGrath // Plant Soil. - 2010. - 332. - P. 5 - 18.

4. Chen, M.X. Effect of iron plaque and selenium on cadmium uptake and translocation in rice seedlings (Oryza sativa) grown in solution culture / M.X. Chen, L. Cao, X.Z. Song, X.Y. Wang, Q.P. Qian, Liu W. // Int. J. Agric. Biol. - 2014. - 16. P. $1159-1164$.

5. Crossette, B. The State of World Population / B. Crossette, U. Devi, L. Laski, J. Mahmood, A. Toure, S. Wong // United Nations Population Fund. - New York, 2010.

6. Ellis, D.R. Plants, selenium and human health / D.R. Ellis, Salt D.E. // Curr. Opin. Plant. Biol. - 2003. - 6. - P. $273-279$.

7. Fageria, N.K. Green manuring in crop production / N.K. Fageria // J. Plant Nutr. - 2007. - 30. - P. $691-719$.

8. Farooq, M. Growing degree days during the late reproductive phase determine spike density and cognate yield traits / M. Farooq, A. Khan, I. Ishaaq, A. Cheema, M. Afzal, A. Ali, J. Zhu // Agronomy. - 2018. - 8. - P. 217.

9. Ge, L. Effects of rootmorphology and leaf transpiration on Cd uptake and translocation in rice under different growth temperature / L. Ge, L. Cang, J. Yang, D. Zhou // Environ. Sci. Pollut. Res. - 2016. - 23. - P. 24205 - 24214.

10. Hussain, S. Changes in morphology, chlorophyll fluorescence performance and Rubisco activity of soybean in response to foliar application of ionic titanium under normal light and shade environment / S. Hussain, N. Iqbal, M. Brestic, M.A. Raza, T. Pang, D.R. Langham, M.E. Safdar, S. Ahmed, B. Wen, Y. Gao // Sci. Total Environ. - 2019. - 658. - P. 626 - 637.

11. Jalloh, M.A. Effect of different $\mathrm{N}$ fertilizer forms on antioxidant capacity and grain yield of rice growing under $\mathrm{Cd}$ stress / M.A. Jalloh, J. Chen, F. Zhen, G. Zhang // J. Hazard. Mater. - 2009. - 162. - P. 1081 - 1085.

12. Kumar, A. Selenium ameliorates arsenic induced oxidative stress through modulation of antioxidant enzymes and thiols in rice (Oryza sativa L.) / A. Kumar, R.P. Singh, P.K. Singh, S. Awasthi, D. Chakrabarty, P.K. Trivedi, R.D. Tripathi // Ecotoxicology. - 2014. - 23. - P. $1153-1163$. 
13. Liang, Y. Study on stability and antioxidant activity of red anthocyanidin glucoside rich hybrid rice, its nutritional and physicochemical characteristics / Y. Liang, M.U. Farooq, Y. Hu, Z. Tang, Y. Zhang, R. Zeng, T. Zheng, H.H. Ei, X. Ye, X. Jia // Food Sci Technol. Res. - 24. - P. 687 - 696.

14. Lin, L. Selenium reduces cadmium uptake and mitigates cadmium toxicity in rice / L. Lin, W. Zhou, H. Dai, F. Cao, G. Zhang, F. Wu // J. Hazard Mater. - 2012. - 235 - 236. - P. $343-351$.

15. Liu, W. Promoting sustainable consumption in China: a conceptual framework and research review / W. Liu, P. Oosterveer, G. Spaargaren // J. Clean Prod. - 2016. - 134. - P. 13 - 21.

16. Luo, J.S. A defensin-like protein drives cadmium efflux and allocation in rice / J.S. Luo, J. Huang, D.L. Zeng, J.S. Peng, G.B. Zhang, H.L. Ma, Y. Guan, H.Y. Yi, Y.L. Fu, B. Han // Nat. Commun. - 2018. - 9. - P. 645.

17. Meharg, A.A. Variation in rice cadmium related to human exposure / A.A. Meharg, N. Gareth, D. Claire, W. Paul, E.E. Adomako, P. Adam, Z. Yongguan, L. Gang, Z. Fang-Jie, M.G. Steve // Environ. Sci. Technol. - 2013. - 47. - P. 5613 - 5618.

18. Nielsen, R. L Heat Unit Concepts Related to Corn Development. Available online: http://www.kingcorn.org/news/ timeless/ HeatUnits.html. Accessed 27 May.

19. Ochagavía, H. Earliness per se by temperature interaction on wheat development / H. Ochagavía, P. Prieto, M. Zikhali, S. Griffiths, G.A. Slafer // Sci. Rep. - 2019. - 9. - P. 2584

20. Williams, P.N. Selenium characterization in the global rice supply chain / P.N. Williams, E. Lombi, G-X Sun // Environ. Sci. Technol. -2009.

21. Peng, K. Cadmium and other metal uptake by Lobelia chinensis and Solanum nigrum from contaminated soils / K. Peng, C. Luo, Y. Chen, G. Wang, X. Li, Z. Shen // Bull. Environ. Contam. Toxicol. - 2009. - 83. - P. 260 - 264.

22. Rayman, M.P. The importance of selenium to human health / M.P. Rayman // Lancet. - 2000. - 356. - P. $233-241$.

23. Roberts, T.L. Cadmium and phosphorous fertilizers: the issues and the science / T.L. Roberts // Procedia Eng. 2014. - 83. - P. $52-59$.

24. Rehman, M.Z. Split application of silicon in cadmium (Cd) spiked alkaline soil plays a vital role in decreasing Cd accumulation in rice (Oryza sativa L.) grains / M.Z. Rehman, M. Rizwan, A. Rauf, M.A. Ayub, S. Ali, M.F. Qayyum, A.A. Waris, A. Naeem, M. Sanaullah // Chemosphere. - 2019.

25. Wan, Y. Cadmium uptake dynamics and translocation in rice seedling: influence of different forms of selenium / Y. Wan, Y. Yu, Q. Wang, Y. Qiao, H. Li // Ecotoxicol. Environ. Saf. - 2016. - 133. - P. 127 - 134.

26. Wang, A.S. Soil pH effects on uptake of $\mathrm{Cd}$ and $\mathrm{Zn}$ by Thlaspi caerulescens / A.S. Wang, J.S. Angle, R.L. Chaney, T.A. Delorme, R.D. Reeves // Plant Soil. - 2006. - 281. - P. 325 - 337.

27. Wang, Y. Mechanistic understanding of MeHg-Se antagonism in soil-rice systems: the key role of antagonism in soil / Y. Wang, F. Dang, R.D. Evans, H. Zhong, J. Zhao, D. Zhou // Sci. Rep. - 2016. - 6. - P. 19477.

28. Yan, F. Effects of wheat straw mulch application and nitrogen management on rice root growth, dry matter accumulation and rice quality in soils of different fertility / F. Yan, Y. Sun, X. Hui, Y. Yin, H. Wang, C. Wang, C. Guo, Z. Yang, Y. Sun, J. Ma // Paddy Water Environ. - 2018. - 16. - P. 1 - 12.

29. Yang, B.B. Selenium (Se) does not reduce cadmium (Cd) uptake and translocation in rice (Oryza sativa L.) in naturally occurred serich paddy fields with a high geological background of Cd / B.B. Yang, C. Yang, Z-Y Shao, H. Wang, S-T Zan, M. Zhu, S-B Zhou, R-Y Yang // Bull Environ. Contam. Toxicol. - 2019. - P. 1 - 6.

30. Ying, H. Effect of selenium fertilization on the accumulation of cadmium and lead in rice plants / H. Ying, G.J. Norton, G. Duan, Y. Huang, Y. Liu // Plant Soil. - 2014. - 384. - P. 131 - 140.

31. Yongzhen, D. The effect of selenium on the subcellular distribution of antimony to regulate the toxicity of antimony in paddy rice / D. Yongzhen, W. Ruigang, G. Junkang, W. Fengchang, X. Yingming, F. Renwei // Environ. Sci. Pollut. Res. 2015. - 22. - P. $5111-5123$.

32. Zhang, H. Selenium in soil inhibits mercury uptake and translocation in rice (Oryza sativa L.) / H. Zhang, X. Feng, J. Zhu, A. Sapkota, B. Meng, H. Yao, H. Qin, T. Larssen // Environ. Sci. Technol. - 2012. - 46. - P. 10040 - 10046.

33. Zhou, H. Heavy metal translocation and accumulation in iron plaques and plant tissues for 32 hybrid rice (Oryza sativa L.) cultivars / H. Zhou, M. Zeng, X. Zhou, B.H. Liao, P.Q. Peng, M. Hu, W. Zhu, Y.J. Wu, Z.J. Zou // Plant Soil. - 2015. 386. - P. $317-329$.

34. Zhu, Y-G Selenium in higher plants: understanding mechanisms for biofortification and phytoremediation / Y-G Zhu, E.A. Pilon-Smits, F-J Zhao, P.N. Williams, A.A. Meharg // Trends Plant Sci. - 2009. - 14. - P. 436 - 442.

35. Zwolak, I. Selenium interactions and toxicity: a review. Selenium interactions and toxicity / I. Zwolak, H. Zaporowska // Cell Biol. Toxicol. - 2012. - 28. - P. 31-46.

\section{Мухаммед Умер Фарук}

E-mail: umerpbguaf@gmail.com Цзянцин Чжу

E-mail: zhujianqing1963@163.com

Bce: Научно-исследовательский институт риса Сычуаньского сельскохозяйственного университета, Чэнду, Сычуань, Китай

\section{Muhammad Umer Farooq}

E-mail: umerpbguaf@gmail.com Jianqing Zhu

E-mail: zhujianqing1963@163.com

All: Rice Research Institute, Sichuan

Agricultural University, Chengdu, Sichuan, China 
DOI: $10.33775 / 1684-2464-2020-49-4-49-56$

УДК 632.9: 632.934
Г.В. Волкова, д-р биол. наук, Е.В. Гладкова, канд. с.-х. наук Ю.С. Ким, аспирант, А.В. Данилова, канд. биол. наук, В.Д. Надыкта, академик РАН г. Краснодар, Россия

\section{ЭФФЕКТИВНОСТЬ ПРОТРАВИТЕЛЕЙ ВИТАЛОН, КС И КЛАД, КС НА ОЗИМОЙ ПШЕНИЦЕ ПРОТИВ СЕМЕННОЙ И ПОЧВЕННОЙ ИНФЕКЦИИ}

Получение высоких урожаев озимой пшеницы не представляется возможным без использования эффективных протравителей. Целью настоящих исследований явилось изучение эффективности двух современных протравителей (Виталон, КС при норме применения 2,0 л/т и Клад, КС при норме применения 0,5 л/т) против комплекса семенной и почвенной инфекции в условиях центральной агроклиматической зоны юга России. Исследования были проведены в 2018 - 2019 гг. на опытном поле ФГБНУ ВНИИБЗР с использованием общепринятых фитопатологических и статистических методов. Против семенной инфекции эффективность протравителя Виталон, КС составила 93 \%, Клад, КС - 79 \% при общей пораженности семян пшеницы озимой сорта Краснодарская 99 - 49 \%. Против корневых гнилей фузариозной этиологии в фазу осеннего кущения при развитии болезни в контроле (без обработки) 4,0 \% эффективность составила 100 \% (Виталон, КС) и 84,4 \% (Клад, КС); в фазу весеннего кущения при развитии болезни в контроле (без обработки) 6,5 \% - 82,9 \% и 76,2 \%; в фазу молочно-восковой спелости зерна при значительном развитии болезни в контроле (без обработки) 28,5 \% - 53,0 \% и 47,0 \% соответственно. Эффективность протравителей против твердой и пыльной головни составила по 100 \% при поражении в контроле (без обработки) - 10,5 \% и 2,0 \% соответственно. Оба препарата обеспечили высокую прибавку урожайности озимой пшеницы, которая составила 25,9 \% (15,0 ц/га) в варианте с протравителем Виталон, КС и 25,2 \% (14,6 ц/га) - Клад, КС.

Ключевые слова: озимая пшеница, протравители, семенная инфекция, корневые гнили, твердая и пыльная головня, эффективность.

\section{EFFECTIVENESS OF VITALON, CS AND CLAD, CS PROTECTANTS ON WINTER WHEAT AGAINST SEED AND SOIL INFECTION}

Getting high yields of winter wheat is not possible without the use of effective dressing agents. The aim of these studies was to study the effectiveness of two modern dressing agents (Vitalon, KS at a rate of $2.0 \mathrm{l} / \mathrm{t}$ and Klad, KS at a rate of $0.5 \mathrm{I} / \mathrm{t}$ ) against a complex of seed and soil infections in the central agro-climatic zone of southern Russia. The studies were carried out in 2018 - 2019 on the experimental field of the FBSSI AIBPP using generally accepted phytopathological and statistical methods. Against seed infection, the effectiveness of the dressing agent Vitalon, KS was $93 \%$, Klada, KS - $79 \%$, with a total infection of seeds of winter wheat varieties Krasnodarskaya 99 - $49 \%$. Against root rot of fusarium etiology in the phase of autumn tillering with the development of the disease in the control (without treatment) $4.0 \%$ efficiency was $100 \%$ (Vitalon, KS) and $84.4 \%$ (Klad, KS); in the phase of spring tillering with the development of the disease in the control (without treatment) $6.5 \%-82.9 \%$ and $76.2 \%$; in the phase of milky-wax ripeness of grain with significant development of the disease in the control (without treatment) $28.5 \%-53.0 \%$ and $47.0 \%$, respectively. The effectiveness of dressing agents against loose and dusty smut was $100 \%$ each with a lesion in the control (without treatment) - $10.5 \%$ and $2.0 \%$, respectively. Both preparations provided a high increase in the yield of winter wheat, which amounted to $25.9 \%$ (15.0 c/ha) in the variant with the dressing agent Vitalon, KS and $25.2 \%$ (14.6 c/ha) - Klad, KS.

Key words: winter wheat, dressing agents, seed infection, root rot, loose and dusty smut, efficiency.

\section{Введение}

Корневые гнили зерновых культур - опасное заболевание, вызываемое комплексом грибов, в который входят представители родов Bipolaris, Fusarium, Pythium, Cercosporella, Gaeumannomyces, Microdochium. Однако более широкое распространение приобрели такие корневые гнили, как фузариозная, церкоспорелезная, гельминтоспориозная и офиоболезная $[5,6,8,26]$. Недобор урожая от корневых гнилей ежегодно достигает 30 \%, а в эпифито- тийные годы потери составляют до 50 - 60 \% урожая $[7,20]$. Благоприятные условия для развития болезни - температура почвы $+13 \ldots+20^{\circ} \mathrm{C}$ и влажность почвы 40...80\%. Сильнее поражаются ослабленные растения с пониженным тургором клеток, а также посевы в севооборотах с высоким насыщением зерновыми злаками [12]. Корневые гнили распространены во всех районах возделывания зерновых культур.

Головня пшеницы опасное заболевание колоса пшеницы, которое имеет широкое географическое 
распространение. Твердая, или вонючая головня, встречается практически во всех зонах выращивания пшеницы в России, но наиболее вредоносна на озимой пшенице в Нечерноземной зоне России, на Северном Кавказе, на Украине (два вида грибов: Tilletia caries (DC.) Tul. (син. T. tritici Wint.) и T. laevis Kuehn. (син T. foetida (Wallr.) Liro)), Западной Азии, Северной Африке, Канаде, Соединенных Штатах и Соединенном Королевстве [27, 28]. Болезнь остается серьезной проблемой, особенно в Северной Африке и Западной Азии [29]. Внешне болезнь пшеницы проявляется в поражении колосьев, где вместо зерен образуются головневые мешочки, или сорусы, наполненные массой телиоспор, издающих резкий селедочный запах из-за присутствия триметиламина.

Пыльная головня Ustilago tritici Jens. встречается везде, где произрастают зерновые растительные культуры: в России, Новой Зеландии, США [30]. Заражение пшеницы пыльной головнёй происходит во время цветения. Проявляется в период колошения в виде типичного пылящего головневого колоса. Неповрежденным остается только стержень [18].

В Юго-Восточном Казахстане в 2015 - 2017 гг. на производственных полях ТОО УНПЦ «Байсерке Агро» изучали вредоносность корневой гнили на озимой и яровой пшенице и зараженность почвы Bipolaris sorokiniana на естественном инфекционном фоне. Установили, что высев пшеницы по пшенице или по ячменю 2 - 3 года подряд приводил к проявлению болезни с баллом 3, урожай при этом снижался на 9,5 - 21,8 и 9,7 - $23 \%$, соответственно [10].

На территории Азербайджана в результате фитосанитарных наблюдений Центра защиты растений Шекинского района было установлено, что в 2013 году на посевах озимой пшеницы по причине корневых гнилей в 15 - 20 \%, а иногда и в 50 \% ростках образовалось разрежение [14].

Фузариозно-гельминтоспориозные корневые гнили с преобладанием видов Fusarium встречаются в Центрально-Черноземном и Северо-Кавказском регионах, гриб Bipolaris sorokiniana обнаруживается преимущественно на яровых культурах в Нечерноземной зоне (Северо-Западный, Центральный, Волго-Вятский регионы) [31, 32].

В 2007 г. в Омской и Новосибирской областях отмечена пораженность корневыми гнилями (Helminthosporium sativum, Alternaria spp., Fusarium spp., Pythium spp., Rhizoctonia spp.), которая ежегодно составляет 15 - 25 \%. Отмечается нарастание развития разных видов Pythium. Потери урожая зерна пшеницы в 2009 - 2010 гг. составили $10-20 \%$, в 2008 г. - 8 \% [15]. В 2013 - 2014 гг. в Адамовском и Оренбургском районах в фазу полной спелости зерна пшеницы, наблюдалось поражение возбудителями корневой гнили. Интенсивность поражения корней озимой пшеницы составила 78 - $85 \%$, яровой мягкой - 48 - $63 \%$, яровой твердой - $33 \%$ $[11,15,16]$. Головневые болезни были выявлены на яровых зерновых культурах 34,79 тыс. га в 2019 г.
В летний период пыльная головня пшеницы фиксировалась в Омской, Томской области с распространением - 0,18 \%. Максимальное распространение 2 \% было выявлено в Первомайском районе Томской области [17].

За период молочно-восковой спелости озимых зерновых культур Пермского края в 2016 году было обследовано 2,71 тыс. га посевов. На обследуемых участках развитие корневых гнилей составило 3,9%, при этом прогнозируемые потери урожая равнялись $0,7 \%$ [11].

Согласно данным М. Ф. Григорьева, в Московской области основой патокомплекса корневых гнилей озимой пшеницы являются грибы рода Fusarium, их встречаемость составляет до 70 \%, второе место среди возбудителей болезни занимает B. sorokiniana, процент встречаемости до 25 [7]. Твердая головня пшеницы в 2019 г. с распространением 0,05 - 0,5 \% отмечалась в Смоленской, Рязанской области. Максимально, 10 \%, отмечено в Красном районе Костромской области на площади 50 га. Пыльная головня пшеницы была распространена в Московской, Тверской, Ярославской областях, распространение составляло - 0,1%. Максимальное распространение 1 \% было выявлено в Пошехонском районе Ярославской области на площади 90 га [17].

Корневые гнили имели распространение на озимой пшенице в Ростовской области, п. Гигант, высеянной по злаковым предшественникам. В 2016 году обследовано 365,8 тыс. га, заражено 88,6 тыс. га, распространение составляло - $25 \%$, развитие $22 \%$ [3].

На озимой пшенице в Краснодарском крае имеют широкое распространение корневые гнили различной этиологии, которые встречаются ежегодно [1, 9]. Известно, что в 2001 году в Северо-Кавказском регионе 1,003 млн. га были поражены корневыми гнилями [9]. По данным Россельхозцентра, в 2011 году площадь поражения корневыми гнилями в Северо-Кавказском регионе составляла 160 тыс. га, обработанные площади протравителями составили в 2011 году 551 тыс. га. [21]. По данным Россельхозцентра, в 2019 г. головневые болезни на озимых зерновых культурах отмечались на 812,3 тыс. га. Летом пыльная головня на пшенице была зафиксирована в республиках Ингушетия, Кабардино-Балкария, Карачаево-Черкесия и в Ставропольском крае с распространением 2 \%. Максимально 5 \% она была отмечена в Прохладненском районе Республики Кабардино-Балкарии на площади 50 га. Твердая головня пшеницы была зафиксирована в Республике Кабардино-Балкарии с распространением - 0,12 \%. Максимальное распространение, 3 \%, было выявлено в Баксанском районе Республики КабардиноБалкарии на площади 20 га [17].

При проведении исследований Андросовой В. М. на научно-исследовательской базе ФГБНУ ВНИИБЗР в период 2012 - 2016 гг., было отмечено поражение 
растений до 4-х баллов и 100 \% распространения ризоктониозной и церкоспореллезной корневых гнилей. Позже, в 2017 - 2018 гг. в ходе маршрутных обследований очаги корневых гнилей были обнаружены в Белоглинском, Каневском, Кущевском, Крыловском районах с развитием болезни 2 - 3 балла. Эксперты связали сложившуюся фитосанитарную обстановку с тем, что севообороты перенасыщены зерновыми культурами. Также, несмотря на относительно засушливую погоду в Краснодарском крае в период маршрутных обследований, утренняя роса скапливалась в прикорневой зоне пшеницы, благодаря чему формировались оптимальные условия для развития болезни [1]. Краснодарский край относится к зоне рискованного земледелия, поэтому существует вероятность создания эпифитотийных условий для развития корневых гнилей.

В последнее время вредоносность от корневых гнилей в Краснодарском крае усиливается. Надежным методом борьбы с возбудителями семенных инфекций является предпосевное протравливание. Использование протравителей позволяет подавить развитие инфекции на пшенице на 60 - $100 \%$. Озимая пшеница поражается корневыми гнилями в течение всей вегетации, поэтому невозможно гарантировать получение полноценного урожая без протравливания семенного материала. Современные протравители имеют широкий ассортимент на отечественном рынке и в среднем позволяют получить дополнительных доход в размере 1600 рублей с гектара $[1,2]$.

\section{Цель исследований}

Изучить эффективность протравителей Виталон, $\mathrm{KC}$ и Клад, KC на озимой пшенице против семенной и почвенной инфекции в условиях центральной агроклиматической зоны юга России.

\section{Материалы и методы}

Опыты проводили на научно-исследовательской базе ФГБНУ ВНИИБЗР в условиях поля. Материалом исследования служил сорт пшеницы Краснодарская 99, восприимчивый к корневым гнилям, умеренно устойчивый к бурой ржавчине, сильно восприимчивый к желтой ржавчине и септориозу и восприимчивый к головневым. Посев был проведен 20 октября 2018 года, норма высева составляла в расчете 200 кг на га.

Для сравнительной характеристики эффективности были выбраны два современных протравителя:

- Виталон, КС - комбинированный фунгицидный препарат контактного и системного действия для протравливания семян. Действующие вещества: тебуконазол - 14 г/л, тирам (ТМТД) - 400 г/л. Химический класс: дитиокарбаматы + триазолы. Фунгицид обладает профилактическим и лечебным действием. Он содержит в своем составе регулятор роста растений крезацин в виде триэтаноламинной соли ортокрезоксиуксусной кислоты. Крезацин повышает всхожесть и энергию прорастания семян, стимулирует рост растений, способствует устойчивости к болезням, повышает устойчивость к неблагоприятным факторам, эффективно защищает зерновые культуры от большинства патогенов [25].

- Клад, КС - трехкомпонентный универсальный фунгицидный протравитель для обработки зерновых с исключительной силой действия против основных болезней. Действующие вещества: имазалил 60 г/л, тебуконазол - 60 г/л, тиабендазол - 80 г/л. Химический класс: бензимидазолы, имидазолы, триазолы. Действующие вещества с различным механизмом действия обеспечивают надежную защиту от семенной и почвенной инфекции. Препарат высокоэффективен против фузариозных и гельминтоспориозных корневых гнилей, снежной плесени, септориоза; защищает от аэрогенных заболеваний на ранних стадиях развития культуры; стимулирует рост корневой системы, что улучшает перезимовку озимых [23].

Протравливание и работы по уходу за растениями проводили вручную.

Анализы для выявления наличия инфицирования семян и его уровня проводили методом влажной камеры [22, 24].

Учеты развития твердой головни на опытных делянках проводили в фазу молочно-восковой спелости путем визуального осмотра колосьев. Учеты развития пыльной головни проводили в фазу цветения путем визуального осмотра колосьев пшеницы [4]. Учёты развития корневых гнилей проводили по стандартным общепринятым методикам [3, 13]. С одного варианта отбирали по 10 проб и учитывали визуально по четырехбалльной шкале. Учеты проводили трехкратно осенью в фазу (Z-21), весной в фазу (Z-29) и летом в фазу (Z-85). Расчет биологической эффективности осуществляли путем соотношения пораженных растений к здоровым по формуле:

$$
C=(A-B) / A \cdot 100 \%
$$

где $C$ - биологическая эффективность; $A$ - количество пораженных растений; $B$ - количество здоровых растений.

Хозяйственную эффективность применения протравителей рассчитывали путем оценки прироста урожая к контролю (без обработки), по формуле:

$$
C=A-B
$$

где $C$ - хозяйственная эффективность; $A$ - урожайность пшеницы, полученная с варианта, где применялись протравители; В - урожайность пшеницы, полученная с контрольного варианта [19].

Наблюдения за агроклиматическими изменениями проводили на метеопосте ФГБНУ ВНИИБЗР. Погодные условия 2018 - 2019 гг. характеризовались обильными осадками в марте и середине мая и умеренными температурами, что благоприятствовало развитию корневых гнилей. 


\section{Результаты и обсуждение}

Фитоэкспертиза семян показала, что во всех вариантах опытах энергия прорастания была равна $100 \%$, кроме контроля (без обработки). Лучшая лабораторная всхожесть отмечена в варианте с Клад, KC (100 \%). Но более эффективно сапрофитную микрофлору подавлял препарат Виталон, КС. Его эффективность против альтернариоза составила 91 \%, в варианте с Клад, КС она была ниже (74 \%). Против плесневых грибов и фузариозов эффективность обоих протравителей составила по $100 \%$ (табл. 1). Биологическая эффективность против комплекса семенной инфекции была выше в варианте с Виталон, КС (93 \%), чем в варианте с Клад, КС (79\%) при значительной пораженности в контроле (без обработки) - 49 \%.

На опытных полях ФГБНУ ВНИИБЗР в течение вегетационного сезона 2018 - 2019 гг. проводили учёты, начиная с фазы начала кущения, для выявления корневых гнилей. Обнаружены возбудители корневых гнилей фузариозной этиологии (Fusarium spp.). Преобладали виды F. graminearum, F. culmorum, F. oxysporum, F. avenaceum. Корневые гнили в осенний период (фаза Z 21) имели низкое развитие - 4,0 \% (табл. 2).

На этом фоне эффективность Виталона, КС составила 100 \%, Клада, КС - 84,4 \%. В фазу конца кущения (весна, фаза Z 29) эффективность против корневых гнилей фузариозной этиологии в варианте с Виталон, КС снизилась до 82,9 \%, с Клад, КС - до 76,2 \% при развитии болезни в контроле (без обработки) $6,5 \%$. В фазу молочно-восковой спелости зерна (фаза Z 82 - 90) преимущество по эффективности также оставалось за препаратом Виталон, КС, эффективность которого составила 53,0 \%, Клада, KC - 47,0 \% при значительном развитии болезни в контроле (без обработки) 28,5\%.

Таблица 1. Фитоэкспертиза семян пшеницы озимой, сорт Краснодарская 99, лаборатория, ФГБНУ ВНИИБЗР, 2018 г.

\begin{tabular}{|c|c|c|c|c|c|c|c|c|c|}
\hline \multirow{4}{*}{ Варианты опыта } & \multirow{4}{*}{ 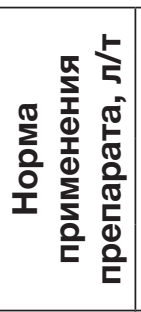 } & \multirow{4}{*}{ 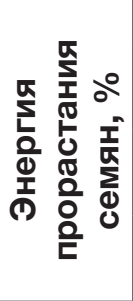 } & \multirow{4}{*}{ 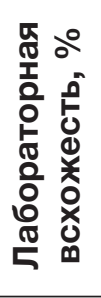 } & \multicolumn{6}{|c|}{ Микрофлора } \\
\hline & & & & \multirow{3}{*}{$\begin{array}{c}\begin{array}{c}\text { сапро- } \\
\text { фитная }\end{array} \\
\text { Altesp } \\
\begin{array}{c}\text { зараже- } \\
\text { но, \% }\end{array}\end{array}$} & \multicolumn{2}{|c|}{ патогенная } & \multirow{3}{*}{ 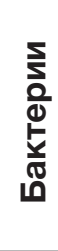 } & \multirow{2}{*}{\multicolumn{2}{|c|}{ Всего }} \\
\hline & & & & & \multirow{2}{*}{\begin{tabular}{|c|} 
прочие \\
плесени*
\end{tabular}} & \multirow{2}{*}{\begin{tabular}{|c|} 
Fusasp \\
зараже- \\
но, \%
\end{tabular}} & & & \\
\hline & & & & & & & & $\begin{array}{c}\text { Зараже- } \\
\text { но, \% }\end{array}$ & $\begin{array}{c}\text { Эффектив } \\
\text { ность, \% }\end{array}$ \\
\hline Виталон, КС & 2,0 & 100 & 97 & 3 & 0 & 0 & 0 & 3 & 93 \\
\hline Клад, КС & 0,5 & 100 & 100 & 9 & 0 & 0 & 0 & 9 & 79 \\
\hline $\begin{array}{l}\text { Контроль } \\
\text { (без обработки) }\end{array}$ & - & 96 & 97 & 40 & 4 & 4 & 1 & 49 & - \\
\hline
\end{tabular}

Примечание: Fusasp - Fusarium spp.; Altesp - Alternaria spp. *- Penicillium spp., Mucor spp.

Таблица 2. Эффективность протравителей против корневых гнилей фузариозной этиологии в условиях центральной агроклиматической зоны, опытное поле ФГБНУ ВНИИБЗР, сорт Краснодарская 99, 2018 - 2019 гг.

\begin{tabular}{|c|c|c|c|c|c|}
\hline \multicolumn{3}{|c|}{ Вариант опыта } & Виталон, КС & Клад, Кс & $\begin{array}{c}\text { Контроль (без } \\
\text { обработки) }\end{array}$ \\
\hline \multicolumn{3}{|c|}{ Норма применения препарата, л/т } & 2,0 & 0,5 & - \\
\hline \multicolumn{3}{|c|}{ Полевая всхожесть семян, \% } & 88,0 & 85,0 & 81,3 \\
\hline \multirow{4}{*}{$\begin{array}{l}\text { Густота стояния } \\
\text { растений, } \\
\text { шт./м² }\end{array}$} & \multicolumn{2}{|c|}{ начало кущения } & 481 & 460 & 450 \\
\hline & \multicolumn{2}{|r|}{$\mathrm{HCP}_{05}$} & \multicolumn{3}{|c|}{18,4} \\
\hline & \multicolumn{2}{|c|}{ конец кущения } & 478 & 458 & 444 \\
\hline & \multicolumn{2}{|r|}{$\mathrm{HCP}_{05}$} & \multicolumn{3}{|c|}{18,4} \\
\hline \multirow{6}{*}{ Fusasp* } & \multirow{2}{*}{ Z 21 (осень) } & развитие, \% & 0,0 & 1,0 & 4,0 \\
\hline & & эффективность, \% & 100 & 84,4 & - \\
\hline & \multirow{2}{*}{ Z 29 (весна) } & развитие, \% & 1,8 & 2,5 & 6,5 \\
\hline & & эффективность, \% & 82,9 & 76,2 & - \\
\hline & \multirow{2}{*}{ Z 82-90 } & развитие, \% & 15,5 & 17,5 & 28,5 \\
\hline & & эффективность, \% & 53,0 & 47,0 & - \\
\hline
\end{tabular}

Эффективность протравителей Виталон, КС и Клад, КС против головневых болезней составляла по 100 \% при поражении в контроле (без обработки) твердой головней - 10,5 \%, пыльной головней - 2,0 \%. 
Установлено повышение общей и продуктивной кустистости в вариантах с применением протравите- лей (табл. 3). Значительная разница выявлена между опытными вариантами и контролем (без обработки).

Таблица 3. Хозяйственная эффективность протравителей Виталон, КС и Клад, КС против комплекса семенной и почвенной инфекции на озимой пшенице, сорт Краснодарская 99, опытное поле ВНИИБЗР, Краснодарский край, 2018 - 2019 гг.

\begin{tabular}{|c|c|c|c|c|c|c|c|}
\hline \multirow[b]{2}{*}{ Вариант опыта } & \multirow{2}{*}{$\begin{array}{c}\text { Норма } \\
\text { примене- } \\
\text { ния препа- } \\
\text { рата, л/т }\end{array}$} & \multicolumn{2}{|c|}{ Кустистость } & \multirow{2}{*}{$\begin{array}{c}\text { Масcа } \\
1000 \\
\text { зерен, г }\end{array}$} & \multirow{2}{*}{$\begin{array}{c}\text { Масса } \\
\text { зерна } \\
\text { с } 1 \text { колоса, г }\end{array}$} & \multicolumn{2}{|c|}{ Урожайность } \\
\hline & & общая & продуктивная & & & ц/га & \% к контролю \\
\hline Виталон, KC & 2,0 & 4,0 & 2,5 & 40,2 & 1,77 & 73,0 & 25,9 \\
\hline $\begin{array}{l}\text { Клад, КС } \\
(60+80+60 \text { г/л) } \\
\text { стандарт }\end{array}$ & 0,5 & 4,0 & 2,4 & 39,9 & 1,75 & 72,6 & 25,2 \\
\hline $\begin{array}{l}\text { Контроль } \\
\text { (без обработки) }\end{array}$ & - & 2,6 & 1,7 & 28,6 & 1,42 & 58,0 & - \\
\hline $\mathrm{HCP}_{05}$ & & & & 1,8 & 0,09 & 1,3 & \\
\hline
\end{tabular}

Структуру урожая определяли по массе 1000 зерен, массе зерна с 1 колоса и урожайности. Максимальные показатели по массе 1000 зерен и массе зерна с 1 колоса отмечены в варианте с Виталон, КС, но статистически достоверная разница между опытными вариантами не выявлена; она отмечена только в сравнении с контролем (без обработки) (табл. 3).

Обработка семян пшеницы озимой сорта Краснодарская 99 протравителем Виталон, КС при норме применения 2,0 л/т обеспечила прибавку урожайности в сравнении с контролем (без обработки) 15 ц/га (или 25,9 \%); протравителем Клад, КС при норме применения 0,5 л/га - 14,6 ц/га (или 25,2 \%). Статистически достоверной разницы между опытными вариантами не выявлено.

\section{Выводы}

В результате изучения действия протравителей Виталон, КС при норме применения 2,0 л/т и Клад, КС при норме применения 0,5 л/т против комплекса семенной инфекции сорта пшеницы Краснодарская 99 (альтернариоз, фузариоз, плесневые грибы, бактерии) установлена их высокая эффективность (93,0 \% и 79,0 \% соответственно) при общей пораженности 49,0 \%.

Установлен значительный фунгицидный эффект протравителей Виталон, КС и Клад, КС против кор- невых гнилей фузариозной этиологии. В фазу осеннего кущения при развитии болезни в контроле (без обработки) 4,0 \% эффективность составила $100 \%$ и 84,4 \%; в фазу весеннего кущения при развитии болезни в контроле (без обработки) 6,5 \% - 82,9 \% и 76,2 \%; в фазу молочно-восковой спелости зерна при значительном развитии болезни в контроле (без обработки) 28,5 \% - 53,0 \% и 47,0 \% соответственно. Протравители на $100 \%$ защитили семенной материал озимой пшеницы сорта Краснодарская 99 от возбудителей твердой и пыльной головни при пораженности в контроле (без обработки) - 10,5 \% и 2,0 \% соответственно.

Отмечено положительное влияние протравителей на показатели энергии прорастания, лабораторной и полевой всхожести семян озимой пшеницы, общей и продуктивной кустистости. Прибавка урожайности, полученная в варианте с Виталон, КС составила 15,0 ц/га (или 25,9 \%), в варианте с Клад, KC - 14,6 ц/га (25,2 \%).

Полученные результаты свидетельствуют о значительном фунгицидном эффекте протравителей Виталон, КС при норме применения 2,0 л/т и Клад, КС при норме применения 0,5 л/т против комплекса семенной и почвенной инфекции на пшенице озимой.

\section{ЛИТЕРАТУРА}

1. Андросова, В.М. Защита озимой пшеницы от ризоктониозно-пиренофорозного комплекса болезней в условиях Краснодарского края / В.М. Андросова, А.О. Диденко, А.Т. Подварко // Международный научно-исследовательский журнал. - Екатеринбург, 2018. - № 12-2(78). - С. 8 - 13.

2. Байбакова, Е.В. Исследование и сравнительный анализ действующих веществ современных протравителей зерновых культур / Е.В. Байбакова, М.Н. Белицкая, И.Р. Грибуст, Е.Э. Нефедьева, И.Г. Шайхиев // Вестник технологического университета. - Казань, 2015. - № 9(18). - С. 32 - 36.

3. Бегляров, Г.А. Химическая и биологическая защита растений / Г.А. Бегляров, А.А. С22. Безукладный, В.Е. Влияние степени распространения болезней на развитие растений озимой пшеницы и формирование урожая / В.Е. Безукладный, Т.Н. Мельникова // Молодая наука аграрного Дона: традиции, опыт, инновации. - 2018. - № 2. - С. 61 - 66.

4. ГОСТ 12044-93 Семена сельскохозяйственных культур. Методы определения зараженности болезнями.

5. Григорьев, М.Ф. Роль микромицетов в поражении зерновых культур корневыми гнилями в Центральном Нечерноземье России / М.Ф. Григорьев// Известия ТСХА. - Москва, 2012. - Вып. 1. - С. 101 - 116. 
6. Григорьев, М.Ф. Региональные исследования корневых гнилей зерновых культур в центральном нечерноземье России (обзор) / М.Ф. Григорьев // Зерновое хозяйство России. - Ростовская обл., Зерноград, 2010. - № 6(12). C. 87-99.

7. Григорьев, М.Ф. Изучение патогенных комплексов возбудителей наиболее распространенных типов корневых гнилей зерновых культур в Центральном Нечерноземье России / М.Ф. Григорьев // Известия ТСХА. - Москва, 2012. № 2. - C. 111 - 125 .

8. Желтова, К.В. Современные средства защиты озимой пшеницы от корневых гнилей / К.В. Желтова, В.И. Долженко // Зернобобовые и крупяные культуры. - Орловская обл., 2016. - № 4(20). - С. 71 - 79.

9. Зазимко, М.И. Фундазол против корневых и прикорневых гнилей / М.И. Зазимко, Э.И. Монастырная, С.З. Мандрыка // Защита и карантин растений. - Москва, 2003. - № 7. - С. 22 - 23.

10. Кочоров, А.С. Влияние предшественника на зараженность почвы Bipolaris sorokiniana и вредоносность корневой гнили пшеницы / А.С. Кочоров, А.О. Сагитов, Н.Ж. Султанова, Г.Е. Кожабаева // Защита и карантин растений. Москва, 2018. - № 9. - С. 15 - 17.

11. Лебедева, Т.И. Влияние приемов обработки почвы и протравителей семян на урожайность и пораженность болезнями озимых зерновых культур в среднем Предуралье / Т.И. Лебедева // Пермский аграрный вестник, Агрономия. - 2017. - № 3(19). - С. 86 - 91.

12. Левитин, М.М. Грибные болезни зерновых культур / М.М. Левитин, С.Л. Тютерев // Защита и карантин растений. - Москва, 2003. - № 11. - С. 54 - 71.

13. Методические указания по регистрационным испытаниям фунгицидов в сельском хозяйстве под ред. В.И. Долженко. - СПб, 2009. - 377 с.

14. Мехдиев, И.Т. Фузариозная болезнь и способ ведения предупредительных мероприятий против нее / И.Т. Мехдиев // Растениеводство и защита растений. - 2014. - С. 99 - 104.

15. Назарова, Л.Н. Фитосанитарное состояние посевов пшеницы в России в 2006 - 2010 гг. / Л.Н. Назарова, Т.М. Полякова, Т.П. Жохова, Л.Г. Корнева // Диагностика и прогнозы. - 2011. - 39 - 43 с.

16. Овсянкина, А.В. Видовое соотношение возбудителей корневой гнили и болезней колоса на посевах пшеницы в Оренбургской области / А.В. Овсянкина, Г.В. Сударенков, А.И. Андреев, С.А. Плыгун, М.И. Киселева // RJOAS. 2017. - № 1(61). - С. 276 - 281.

17. Обзор фитосанитарного состояния посевов сельскохозяйственных культур в Российской федерации в 2019 году и прогноз развития вредных объектов в 2020 году, М., 2020 - 897 с.

18. Пересыпкин, В.Ф. Сельскохозяйственная фитопатология: учебник. М.: Агропромиздат. - 1989. - 480 с.

19. Попов, С.Я. Основы химической защиты растений. Попов С.Я., Дорожкина Л.А., Калинин В.А. / Под ред. профессора С.Я. Попова. - М.: Арт-Лион, 2003. - 208 с.

20. Санин, С.С. Химическая защита пшеницы от болезней при интенсивном зернопроизводстве / С.С. Санин, А.А. Мотовилин, Л.Г. Корнева, Т.П. Жохова, Т.М. Полякова, Е.А. Акимова // Защита и карантин растений. - Москва, 2011 - № 8. - С. 3 - 8.

21. Санин, С.С. Семеноводство не должно быть фактором риска / С.С. Санин, А.В. Филиппов // Защита и карантин растений. - 2003. - № 1. - С. 10 - 12.

22. Сайты: Российский сельскохозяйственный центра [Электронный ресурс] Режим довступа https://rosselhoscenter.com.

23. Сайт Пестициды.ru: Виталон, КС [Электронный ресурс] Режим доступа: https://www.pesticidy.ru/pesticide/vitalon (Дата обращения: 25.05.20).

24. Сайт Пестициды.ru: Клад, КС [Электронный ресурс] Режим доступа: https://www.pesticidy.ru/pesticide/klad (Дата обращения: 25.05.20).

25. Тойгицын, А.Л. Эффективность фунгицидов на озимой пшенице / А.Л. Тойгицин, М.И. Подсевалов, Д.Э. Аюпов // Защита и карантин. - Москва, 2014. - № 11. - С. 37 - 41.

26. Bodah, E.T. Root Rot Diseases in Plants: A Review of Common Causal Agents and Management Strategies / E. Bodah // Agri Res \& Tech: Open Access J. - 2017. - № 5(3). - P. 1.

27. Matanguihan, J.B. A New Pathogenic Race of Tilletia caries possessing the broadest virulence spectrum of known races / J.B. Matanguihan, S.S. Jones // Online Plant Health Progress. 2011. Doi: 10.1094/PHP-2010-0520-01-RS.

28. El-Naimi, M. Organic seed-treatment as a substitute for chemical seed-treatment to control common bunt of wheat European / M. El-Naimi, H. Toubia-Rahme, OF. Mamluk // Journal of Plant Pathology. - 2000. - №106. - P. 433 - 437.

29. Josefsen, L. PCR as a tool for the early detection and diagnosis of common bunt in wheat caused by Tilletia tritici / L. Josefsen, K.S. Christiansen // Mycol. Res. - 2002. - № 106. - P. 1287 - 1292.

30. Kaur, G. Characterization of Ustilago segetum tritici causing loose smut of wheat in northwestern India / G. Kaur, I. Sharma, R.C. Sharma // Canadian Journal of Plant Pathology. - 2014. № 36. V. 3. - P. 360 - 366. doi:10.1080/07060661. 2014.924559 .

31. Chulkina, V.I. Kornevye gnili khlebnykh zlakov v Sibiri [Root rots of cereals in Siberia] / V.I. Chulkina // Novosibirsk.1985. - P. 25.

32. Kiseleva, M.I. Barley Root Rot agents in different areas of Russia. APS/SON Joint Meeting (July 28-August 1, 2007, San Diego, USA) / M. Kiseleva, E. Kovalenko // APS Meeting Abstracts. Phytophatology. - 1997. - № 7. - P. 57. 


\section{REFERENCES}

1. Androsova, V.M. Protection of winter wheat from rhizoctonia-pyrenophorous complex of diseases in the Krasnodar Territory / V.M. Androsova, A.O. Didenko, A.T. Podvarko // International scientific research journal. - Yekaterinburg, 2018. № 12-2 (78). - P. 8-13.

2. Baybakova, E.V. Research and comparative analysis of active substances of modern grain dressing agents / E.V. Baybakova, M.N. Belitskaya, I.R. Gribust, E.E. Nefedieva, I.G. Shaikhiev // Technological University Bulletin. - Kazan, 2015. № 9(18). - P. 32 - 36 .

3. Beglyarov, G.A. Chemical and biological protection of plants / G.A. Beglyarov, A.A. Bezukladny, V.E. Influence of the spread of diseases on the development of winter wheat plants and yield formation / V.E. Bezukladny, T.N. Melnikova // Young science of the agrarian Don: traditions, experience, innovations. - 2018. - № 2. - P. 61 - 66 .

4. GOST 12044-93 Agricultural seeds. Methods for determining the incidence of diseases.

5. Grigoriev, M.F. The role of micromycetes in the defeat of grain crops by root rot in the Central Non-Black Earth Region of Russia / M.F. Grigoriev // Izvestiya TSKHA. - Moscow, 2012. - Issue. 1. - P. 101 - 116.

6. Grigoriev, M.F. Regional studies of root rot of grain crops in the central non-black soil of Russia (review) / M.F. Grigoriev // Grain economy of Russia. - Rostov region, Zernograd, 2010. - № 6(12). - P. 87 - 99.

7. Grigoriev, MF Study of pathogenic complexes of pathogens of the most common types of root rot of grain crops in the Central Non-Black Earth Region of Russia / MF Grigoriev // Izvestiya TSKhA. - Moscow, 2012. - № 2. - P. 111 - 125.

8. Zheltova, K.V. Modern means of protecting winter wheat from root rot / K.V. Zheltova, V.I. Dolzhenko // Legumes and cereals. - Oryol region, 2016. - № 4(20). - P. 71 - 79.

9. Zazimko, M.I. Fundazol against root and root rot / M.I. Zazimko, El Monastyrnaya, SZ Mandryka // Plant protection and quarantine. -2003 . - № 7. - P. 22 - 23.

10. Kochorov, A.S. Influence of the predecessor on soil infestation with Bipolaris sorokiniana and harmfulness of wheat root rot / A.S. Kochorov, A.O. Sagitov, N.Zh. Sultanova, G.E. Kozhabaeva // Plant protection and quarantine ... - Moscow, 2018. - № 9. - P. 15 - 17.

11. Lebedeva, T.I. Influence of soil cultivation and seed dressing methods on yield and disease incidence of winter grain crops in the middle Cis-Urals / T.I. Lebedeva // Perm Agrarian Bulletin, Agronomy. - 2017. - № 3(19). - P. 86 - 91.

12. Levitin, M.M. Fungal diseases of grain crops / M.M. Levitin, S.L. Tyuterev // Plant protection and quarantine. - Moscow, 2003. - № 11. - P. 54 - 71.

13. Guidelines for registration tests of fungicides in agriculture, ed. V.I. Dolzhenko. - SPb, 2009. - 377 p.

14. Mehdiev, I.T. Fusarium disease and the method of conducting preventive measures against it / I.T. Mehdiev // Plant growing and plant protection. - 2014 . - P. $99-104$.

15. Nazarova, L.N. Phytosanitary state of wheat crops in Russia in 2006 - 2010. / L.N. Nazarova, T.M. Polyakova, T.P. Zhokhova, L.G. Korneva // Diagnostics and forecasts. - 2011. - P. $39-43$.

16. Ovsyankina, A.V. Species ratio of root rot pathogens and ear diseases on wheat in the Orenburg region / A.V. Ovsyankina, G.V. Sudarenkov, A.I. Andreev, S.A. Plygun, M.I. Kiseleva // RJOAS. - 2017. - № 1(61). - P. 276 - 281.

17. Review of the phytosanitary state of agricultural crops in the Russian Federation in 2019 and the forecast of the development of harmful objects in 2020, M., 2020. - 897 p.

18. Peresypkin, V.F. Agricultural phytopathology: textbook. M.: Agropromizdat. - 1989. - 480 p.

19. Popov, S.Ya. Fundamentals of chemical plant protection / Popov S.Ya., Dorozhkina L.A., Kalinin V.A. // Ed. Professor S.Ya. Popov. - M.: Art-Lyon, 2003. - 208 p.

20. Sanin, S.S. Chemical protection of wheat from diseases in intensive grain production / S.S. Sanin, A.A. Motovilin, L.G. Korneva, T.P. Zhokhova, T.M. Polyakova, E.A Akimova // Plant protection and quarantine. - Moscow, 2011 - № 8. P. $3-8$.

21. Sanin, S.S. Seed growing should not be a risk factor / S.S. Sanin, A.V. Filippov // Plant protection and quarantine. 2003. - № 1. - P. 10 - 12.

22. Sites: Russian Agricultural Center [Electronic resource] Additional access mode https://rosselhoscenter.com.

23. Site Pesticides.ru: Vitalon, KS [Electronic resource] Access mode: https://www.pesticidy.ru/pesticide/vitalon (Date of access: 25.05.20).

24. Site Pesticides.ru: Treasure, KS [Electronic resource] Access mode: https://www.pesticidy.ru/pesticide/klad (Date of access: 25.05 .20$)$.

25. Toygitsyn, A.L. Efficiency of fungicides on winter wheat / A.L. Toygitsin, M.I. Podsevalov, D.E. Ayupov // Protection and quarantine. - Moscow, 2014. - № 11. - P. 37 - 41.

26. Bodah, E.T. Root Rot Diseases in Plants: A Review of Common Causal Agents and Management Strategies / E. Bodah // Agri Res \& Tech: Open Access J. - 2017. - № 5(3). - P. 1.

27. Matanguihan, J. B. A New Pathogenic Race of Tilletia caries possessing the broadest virulence spectrum of known races / J. B. Matanguihan, S.S. Jones // Online Plant Health Progress. 2011. Doi: 10.1094 / PHP-2010-0520-01-RS.

28. El-Naimi, M. Organic seed-treatment as a substitute for chemical seed-treatment to control common bunt of wheat European / M. El-Naimi, H. Toubia-Rahme, OF. Mamluk // Journal of Plant Pathology. - 2000. - № 106. - P. 433 - 437.

29. Josefsen, L. PCR as a tool for the early detection and diagnosis of common bunt in wheat caused by Tilletia tritici / L. Josefsen, K. S. Christiansen // Mycol. Res. - 2002. - № 106. - P. 1287 - 1292. 
30. Kaur, G. Characterization of Ustilago segetum tritici causing loose smut of wheat in northwestern India / G. Kaur, I. Sharma, R. C. Sharma // Canadian Journal of Plant Pathology. - 2014. № 36. V.3. - P. 360 - 366. doi: 10.1080 / 07060661.2014.924559.

31. Chulkina, V.I. Kornevye gnili khlebnykh zlakov v Sibiri [Root rots of cereals in Siberia]. / V.I. Chulkina // Novosibirsk. 1985. - P. 25

32. Kiseleva, M.I. Barley Root Rot agents in different areas of Russia. APS / SON Joint Meeting (July 28-August 1, 2007, San Diego, USA) / M. Kiseleva, E. Kovalenko // APS Meeting Abstracts. Phytophatology. - 1997. - № 7. - P. 57.

\section{Волкова Галина Владимировна}

Главный научный сотрудник, заведующая лабораторией иммунитета зерновых культур к грибным болезням E-mail: galvol.bpp@yandex.ru 79183747678

\section{Екатерина Витальевна Гладкова}

Старший научный сотрудник лаборатории иммунитета зерновых культур к грибным болезням E-mail: kat288tey299@mail.ru

\section{Ким Юрий Сергеевич}

Младший научный сотрудник лаборатории иммунитета зерновых культур к грибным болезням E-mail: kimiur@yandex.ru 79628546636

\section{Данилова Анастасия Валерьевна}

Старший научный сотрудник лаборатории иммунитета зерновых культур к грибным болезням E-mail: starlight001@yandex.ru

79528126261

\section{Надыкта Владимир Дмитриевич \\ E-mail: nadykta46@mail.ru \\ 79189483635}

\section{Все: ФГБНУ «Всероссийский} научно-исследовательский институт биологической защиты растений» 350039, Россия, Краснодарский край, г. Краснодар, п/о 39

\section{Galina Vladimirovna Volkova \\ Chief Researcher, head of the laboratory of immunity of grain crops to fungal diseases E-mail: galvol.bpp@yandex.ru 79183747678}

\section{Ekaterina Vitalievna Gladkova}

Senior researcher at the laboratory

of immunity of grain crops to fungal diseases

E-mail: kat288tey299@mail.ru

\section{Yuri Sergeevich Kim}

Junior researcher at the laboratory

of immunity of grain crops to fungal diseases

E-mail: kimiur@yandex.ru

79628546636

\section{Anastasia Valerievna Danilova}

Senior researcher at the laboratory

of immunity of grain crops to fungal diseases

E-mail: starlight001@yandex.ru

89528126261

\section{Vladimir Dmitrievich Nadykta \\ E-mail: nadykta46@mail.ru \\ 79189483635}

All: FSBSI "All-Russian

Scientific Research Institute of Biological Plant Protection" p/o 39, Krasnodar, Krasnodar territory, 350039, Russia 


\section{ОЦЕНКА ИСХОДНОГО МАТЕРИАЛА В СЕЛЕКЦИОННОМ ПРОЦЕССЕ ЖАРОСТОЙКИХ СОРТОВ ТОМАТА ДЛЯ ЮГА РОССИИ}

Важным этапом в селекционном процессе при создании гибридов $F_{1}$ является поиск источников и доноров ценных хозяйственных признаков. В последние годы на юге России в период вегетации томата преобладает сухая и жаркая погода. Высокая температура окружающей среды подавляет рост и развитие томата, тем самым снижая его урожайность и качество. На теплостойкость растений оказывает влияние окружающая среда, агротехника и особенно генотип. Поэтому целью проводимых нами исследований являлось изучение жаростойкости консервных сортов томата в лабораторных условиях для поиска генотипов растений, обладающих высокой устойчивостью к температурному стрессу, для дальнейшего использования в селекции высокопродуктивных сортов и гибридов. Исследования проводились в 2018 - 2020 гг. В статье представлены результаты оценки шести среднеспелых образцов томата, пригодных для переработки на томатопродукты и цельноплодное консервирование. По результатам лабораторных исследований выявлены сортообразцы, обладающие повышенной жароустойчивостью растений (ЛК-2840, ЛГ-1181), слабую органическую жаростойкость проявили сорта Мираж и Рокер. В 2019 году, ввиду сложившихся условий, наблюдалась эпифитотия вирусных заболеваний и столбура, что не позволило оценить урожайность томата. В 2018 и 2020 гг. на изменчивость урожайности в большей степени (78,9 \%) оказывали влияние сортовые особенности изученных образов. Погодные условия также оказывали существенное влияние на урожайность, хотя и в меньшей степени (20,6 \%). Проведено скрещивание и получены гибридные комбинации с участием жароустойчивых образцов для дальнейшего изучения наследования этого признака.

Ключевые слова: томат, температурный стресс, сортообразец, органическая жаростойкость, степень поражения, урожайность.

\section{EVALUATION OF STARTING MATERIAL WHEN BREEDING HEAT RESISTANT TOMATO VARIET- IES FOR THE SOUTH OF RUSSIA}

An important stage in the breeding process when developing $F_{1}$ hybrids is the search for sources and donors of valuable economic traits. In recent years, dry and hot weather prevails in the south of Russia during the growing season of tomato. High ambient temperatures inhibit the growth and development of tomato, thereby reducing its yield and quality. The heat resistance of plants is influenced by the environment, agricultural technology and especially the genotype. Therefore, the purpose of our research was to study the heat resistance of canned tomato varieties in laboratory conditions to search for plant genotypes with high heat resistance, for further use in breeding highly productive varieties and hybrids. The studies were carried out in $2018-2020$. The article presents the results of the assessment of six mid-season tomato samples suitable for processing into tomato products and whole-fruit canning. According to the results of laboratory studies, varieties with increased heat resistance of plants have been identified (LK-2840, LG-1181), weak organic heat resistance was shown by varieties Mirage and Roker. In 2019, due to the prevailing conditions, an epiphytoty of viral diseases and stolbur was observed, which did not allow assessing the yield of tomato. In 2018 and 2020 the variability of productivity to a greater extent (78,9 \%) was influenced by the varietal characteristics of the studied samples. Weather conditions also had a significant impact on yield, although to a lesser extent (20.6\%). Crossing was carried out and hybrid combinations were obtained with the participation of heat-resistant samples for further study of the inheritance of this trait.

Key words: tomato, temperature stress, sample, organic heat resistance, degree of damage, yield.

\section{Введение}

Вопросы повышения устойчивости растений к биотическим и абиотическим факторам среды стали особо актуальными в последние годы в связи с локальными изменениями погодно-климатических условий. Устойчивость растений к неблагоприятным факторам внешней среды представляет важную проблему для сельскохозяйственного производства. Высокотемпературный стресс является главным экологическим стрессом, который ограничивает рост, метаболизм и продуктивность растений во всем мире [12]. Свидетельства глобального потепления повы- сили интерес к причине снижения урожайности при температурах лишь немного выше оптимальных для многих культур, включая томаты. По данным Hazra P. et al. тепловой стресс может возникать у томатов при среднесуточных температурах 28 - $29{ }^{\circ} \mathrm{C}$ [13]. Тепловой стресс вызывает многообразные, а зачастую и неблагоприятные изменения в росте, развитии, физиологических процессах растений и урожайности.

Томат - одна из самых популярных овощных культур на Кубани. При высоких температурах нормальные физиологические функции растения угнетаются, 
а при температуре около $50^{\circ} \mathrm{C}$ происходят свертывание протоплазмы и отмирание клеток [14]. При этом интенсивные сорта могут реализовать лишь 15-30 \% потенциальной продуктивности [9]. Перегревы в районах с жарким климатом часто являются причиной стерилизации пыльцы, депрессии фотосинтеза, нарушения обмена веществ, в результате тормозится рост и развитие растений, замедляется или совсем прекращается плодообразование, происходит опадение завязей [5]. При этом повреждаются и уже сформированные плоды, так как при длительном воздействии температур выше $32{ }^{\circ} \mathrm{C}$ прекращается образование пигментов ликопина и каротина, формируются плоды с желтыми пятнами, наблюдаются ожоги, растрескивание плодов [11].

В зоне южного овощеводства среди многочисленных стресс-факторов окружающей среды высокотемпературный, является лимитирующим для получения высоких урожаев при выращивании томата. Превышение оптимального температурного уровня приводит к снижению эффективности фотосинтеза [15]. Это вызывает разрушение белково-липидных комплексов плазмаллемы и других клеточных мембран, приводит к потере осмотических свойств клетки. В результате наблюдаются дезорганизация многих функций клеток, снижение скорости различных физиологических процессов. Так, при температуре $20^{\circ} \mathrm{C}$ все клетки проходят процесс митотического деления, при $38^{\circ} \mathrm{C}$ митоз отмечается в каждой седьмой клетке, а повышение температуры до $42{ }^{\circ} \mathrm{C}$ снижает число делящихся клеток в 500 раз (одна делящаяся клетка на 513 неделящихся) $[6,16]$. При повышении температуры выше оптимальной вода в тканях растений нагревается, отток ассимилянтов из листьев ослабевает, происходит распад белков и накопление небелковых форм азота, в частности аммиака, который действует на протоплазму токсически, нарушается обмен веществ и, как следствие этого, накапливаются ядовитые вещества. При более высоких температурах резко повышается проницаемость цитоплазматических мембран, а затем наступает коагуляция белков и отмирание клеток [8].

Выявление генов, чувствительных к высокотемпературному стрессу (HSR), и выведение теплостойких сортов является эффективным способом решения этой проблемы, что важно не только на начальном этапе, но и позднее в селекционном процессе [17]. Присущий каждому сорту уровень устойчивости к высоким температурам является генетически контролируемым и наследуемым признаком. Однако этот признак - потенциальный. В оптимальных условиях он скрыт и проявляется лишь тогда, когда растения оказываются под влиянием экстремального фактора. Для диагностики устойчивости растений, наряду с действием естественных факторов, необходимо моделировать воздействие температурным стрессом в лабораторных условиях [15]. В связи с этим создание сортов с высокой экологической пластичностью, устойчивых к лимитирующим факторам среды, в частности к высоким летним температурам, является одним из приоритетных направлений селекции томата на юге России [2, 6].

Существует два типа жаростойкости растений органическая и обусловленная. Жаростойкость органическую можно назвать истинной, так как она определяется высокой термостабильностью биоколлоидов, выдерживающих без коагуляции прямое действие высоких температур порядка 50 - $60^{\circ} \mathrm{C}$ [2]. Жаростойкость обусловленная заключается в способности растения не допускать перегрева благодаря наличию защитных средств.

Рост и развитие растений связаны с многочисленными биохимическими реакциями, чувствительными к температуре. Реакция растений на высокую температуру зависит от степени и продолжительности ее воздействия, возраста растения. Растения обладают рядом приспособительных или акклиматизирующих механизмов для того, чтобы справляться с ситуациями стресса [12]. Растения могут избегать теплового стресса за счет уменьшения поглощения солнечной радиации. Эта способность поддерживается наличием мелких волосков (томентоз) на поверхности листа. У таких растений листовые пластинки часто отворачиваются от света и ориентируются параллельно солнечным лучам (парагелиотропизм). У томата механизмом, регулирующим температуру самого растения, является облиственность кустов способствующая усиленной транспирации и притенению генеративных органов и плодов; складывание и скручивание листьев; наличие опущения, защищающее от перегрева глубжележащие ткани.

Морфологические симптомы теплового стресса включают солнечные ожоги листьев, ветвей и стеблей, торможение роста побегов и корней, обесцвечивание и повреждение плодов, повреждение кончика и краев листа, скатывание и их высыхание [12].

\section{Цель исследований}

Изучить органическую жаростойкость консервных сортов томата в лабораторных условиях для поиска источников хозяйственно ценных признаков, обладающих высокой устойчивостью к тепловому стрессу для дальнейшего использования в селекции высокопродуктивных сортов и гибридов.

\section{Материалы и методы}

Исследования проводили в лабораторных и полевых условиях на территории опытного участка отдела овощеводства ФГБНУ «ФНЦ риса» в 2018 - 2020 годах в соответствии с «Методикой полевого опыта в овощеводстве» [7]. Результаты исследований обработаны методами биометрической статистики [4, 10], анализ метеорологических показателей, их сопоставление со средними многолетними значениями - по данным метеостанции Краснодар-Круглик г. Краснодара [1]. Измерение температуры воздуха в тени кустов томата и над поверхностью растений проводили 1 раз в день в 14 часов с 14 июня по 15 июля (период цветения и завязывания плодов томата). 
Объектом исследований выбраны среднеспелые образцы томата, отвечающие современным технологиям выращивания и уборки плодов, пригодные для переработки на томатопродукты и цельноплодное консервирование. Стандарт - сорт Мираж. Рассаду выращивали в пластиковых кассетах в теплице с пленочным покрытием и аварийным обогревом. Посев семян в кассеты провели в конце марта - первых числах апреля. Массовые всходы были получены через 7 - 10 дней. В открытый грунт рассаду высаживали в возрасте 28 дней в начале мая. Агротехнические работы на опытном участке выполняли в соответствии с рекомендациями по выращиванию томата, разработанными отделом овощекартофелеводства ФГБНУ «ФНЦ риса» [3]. Для орошения использовали капельный полив.

В соответствии с поставленными задачами в лабораторных условиях проводили оценку органической жаростойкости сортообразцов томата по методу Ф.Ф. Мацкова [8]. По теории Ф.Ф. Мацкова «Если подвергнуть фрагменты листа действию высокой температуры, а затем погрузить в раствор соляной кислоты, то поврежденные и мертвые клетки побуреют вследствие свободного проникновения в них кислоты, которая вызовет превращение хлорофилла в феофитин, тогда как неповрежденные клетки останутся зелеными. Вследствие утраты отмирающей цитоплазмой свойства полупроницаемости, кислота проникает внутрь хлоропластов, и водород кислоты вытесняет магний из молекулы хлорофилла, превращая его в феофитин - соединение бурого цвета»

Жароустойчивость в значительной степени определяется фазой роста и развития растений. Наибольший вред высокие температуры причиняют на ранних этапах развития органов растения, так как молодые, активно растущие ткани менее устойчивы, чем «старые» и «покоящиеся». Поэтому для проведения анализа по определению жаростойкости брали однородный по положению на растении материал (листья одного возраста, расположенные на побегах одного порядка и т.д.) - молодые листья томата в наиболее уязвимую для растений фазу фазу цветения. Различный температурный режим воздействия на фрагменты листа устанавливали при помощи термостата. Оценку проводили глазомерно по степени побурения листовой пластинки.

\section{Результаты и обсуждение}

Для выявления степени влияния температурного стресса на растения консервных сортов томата были проанализированы температурные показатели с 14 июня по 15 июля 2018 - 2020 гг. (табл. 1). Этот период является наиболее критическим в развитии растений. В это время происходит цветение, завязывание и налив плодов.

Практически всегда температура воздуха над поверхностью растений была выше, чем в глубине куста, особенно в ясные безоблачные дни.

В наиболее жаркие дни периода вегетации растений томата 2018 года, воздух над растениями прогревался до $50-54^{\circ} \mathrm{C}$. За июнь сумма активных температур составила $707,7^{\circ} \mathrm{C}$, что выше среднегодовой на 65,8 ${ }^{\circ} \mathrm{C} .28$ июня был зафиксирован температурный рекорд. Днем температура воздуха в тени растений поднялась до отметки $39,3^{\circ} \mathrm{C}$, а над растениями - до $54^{\circ} \mathrm{C}$. За июль сумма активных температур составила $810,7^{\circ} \mathrm{C}$, что выше нормы на $57,1^{\circ} \mathrm{C}$. Выпадение осадков носило локальный характер.

Самым жарким месяцем 2019 года был июнь. По данным метеостанции Краснодар-Круглик г. Краснодара, был зафиксирован температурный рекорд по отклонению от среднегодовой нормы месяца. Среднемесячные температуры превышали среднемноголетние показатели на $4,0{ }^{\circ} \mathrm{C}$, температурный максимум в ясные солнечные дни достигал $50,7^{\circ} \mathrm{C}$. Сумма активных температур за месяц составила $758,4^{\circ} \mathrm{C}$, что выше среднегодовой на $119,9^{\circ} \mathrm{C}$. За июль сумма активных температур составила $711,7^{\circ} \mathrm{C}$, что ниже нормы на $41,9^{\circ} \mathrm{C}$. Месяц был прохладным и дождливым, хотя в некоторые дни температура воздуха над растениями превышала $40^{\circ} \mathrm{C}$.

Июнь 2020 года был прохладным, но сухим. Сумма активных температур за месяц составила $686,2{ }^{\circ} \mathrm{C}$, что ниже среднегодовой на $10,7^{\circ} \mathrm{C}$. Температура воздуха над растениями колебалась в пределах 26,6 - 40,8 ${ }^{\circ} \mathrm{C}$. Резкое повышение температуры в первую декаду июля не сильно сказалось на плодоношении томата. Растения находились в завершающей фазе цветения боковых побегов. Большая часть плодов на растении была сформирована.

Таблица 1. Анализ погодных условий в наиболее подверженный температурному стрессу период вегетации растений томата (цветение, завязывание плодов) 2018 - 2020 гг.

\begin{tabular}{|c|c|c|c|c|c|c|}
\hline \multirow{2}{*}{ Год } & \multicolumn{3}{|c|}{$\begin{array}{c}\text { Количество дней } \\
\text { с температурой воздуха более } 33^{\circ} \mathrm{C} \\
\text { над поверхностью растений }\end{array}$} & \multicolumn{3}{|c|}{$\begin{array}{c}\text { Количество дней } \\
\text { с влажностью воздуха более } 70 \text { \% }\end{array}$} \\
\hline & 14 - 30 июня & 01 - 15 июля & $\begin{array}{c}\text { Итого } \\
\text { за период } \\
\text { цветения }\end{array}$ & 14 - 30 июня & 01 - 15 июля & $\begin{array}{c}\text { Итого } \\
\text { за период } \\
\text { цветения }\end{array}$ \\
\hline 2018 & 10 & 9 & 19 & 4 & 4 & 8 \\
\hline 2019 & 15 & 8 & 23 & 10 & 8 & 18 \\
\hline 2020 & 6 & 11 & 17 & 3 & 4 & 7 \\
\hline
\end{tabular}


Способом защиты от перегрева может служить усиленная транспирация, обеспечиваемая мощной корневой системой томата. В результате транспирации температура в тени растений снижалась, иногда на $12-17^{\circ} \mathrm{C}$. Растения томата сухую жаркую погоду переносят легче, чем влажную, так как во время жары при высокой влажности воздуха регуляция температуры листьев за счет транспирации ограничена. Содержание влаги в почве регулировали капельным поливом. Это помогло растениям снивелировать действие теплового шока и дать урожай.

Фотосинтез является одним из наиболее чувствительных к теплу физиологических процессов в растениях. Высокая температура оказывает большое влияние на фотосинтетическую способность растений. Для установления температурного режима воздействия на листья томата, который бы позволил идентифицировать и классифицировать изучаемые исходные формы по характеру и степени проявления их устойчивости к высокотемпературному фактору, в лабораторных условиях при помощи термостата использовали восемь режимов: $40{ }^{\circ} \mathrm{C}$; $45^{\circ} \mathrm{C} ; 50^{\circ} \mathrm{C} ; 55^{\circ} \mathrm{C} ; 60^{\circ} \mathrm{C} ; 65^{\circ} \mathrm{C} ; 70^{\circ} \mathrm{C}$ и $75^{\circ} \mathrm{C}$ с временной экспозицией воздействия на фрагменты листовой пластинки в 10 минут. Степень поражения листа 0 - 10 \% характеризовали как «отсутствия поражения», 10 - 30 \% - «слабое поражение», 30 - 50 \% - «среднее поражение», 50 - 80 \% - «силь- ное поражение», 80 - 100 \% - «сплошное поражение».

Поражение фрагментов листа при действии высоких температур на листовые пластинки сортообразцов, проявляющееся в отмирании и побурении клеток, изменялось от «отсутствия поражения» до «сплошного».

При воздействии на листья томата температуры $40{ }^{\circ} \mathrm{C}$ повреждений клеток растений всех образцов не наблюдалось или они были незначительны (табл. 2). При $45^{\circ} \mathrm{C}$ у сорта Мираж началось слабое поражение фрагментов листа, остальные образцы оставались без изменения. При повышении температуры до $50{ }^{\circ} \mathrm{C}$ поражение до 30 \% наблюдалось у всех образцов кроме ЛГ - 1181; при увеличении температуры до $55^{\circ} \mathrm{C}$ разрушение хлоропластов до 50 \% наблюдалось у сортов Мираж и Рокер, остальные образцы имели слабое поражение листовой пластинки. Сортообразцы ЛК - 2840 и ЛГ - 1181 обладали наибольшей органической жаростойкостью. Среднее поражение листовой пластинки (до 50 \% поверхности листа) наблюдалось у них при повышении температуры до $65^{\circ} \mathrm{C}$. К среднеустойчивым можно отнести образцы ЛК-2926 и ЛК-2704/09, слабую органическую жаростойкость проявили сорта Мираж и Рокер. Полное поражение клеток всех образцов произошло при $75^{\circ} \mathrm{C}$. Тот же результат был подтвержден и в последующих сезонах выращивания.

Таблица 2. Степень поражения листьев консервных сортов томата при воздействии на них различными температурами

\begin{tabular}{|c|c|c|c|c|c|c|c|c|c|c|c|c|c|c|c|c|c|c|c|c|c|c|c|c|c|c|c|c|c|c|c|c|}
\hline \multirow[b]{4}{*}{ Образец } & \multicolumn{32}{|c|}{ Температуры воздействия } \\
\hline & \multicolumn{4}{|c|}{$40^{\circ} \mathrm{C}$} & \multicolumn{4}{|c|}{$45^{\circ} \mathrm{C}$} & \multicolumn{4}{|c|}{$50^{\circ} \mathrm{C}$} & \multicolumn{4}{|c|}{$55^{\circ} \mathrm{C}$} & \multicolumn{4}{|c|}{$60^{\circ} \mathrm{C}$} & \multicolumn{4}{|c|}{$65^{\circ} \mathrm{C}$} & \multicolumn{4}{|c|}{$70^{\circ} \mathrm{C}$} & \multicolumn{4}{|c|}{$75^{\circ} \mathrm{C}$} \\
\hline & \multicolumn{32}{|c|}{ Степень поражения листа } \\
\hline & 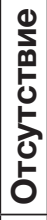 & $\begin{array}{l}1 \\
0 \\
0 \\
0 \\
5 \\
0 \\
0\end{array}$ & 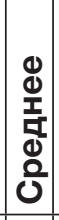 & $\begin{array}{l}0 \\
0 \\
0 \\
\mathbf{1} \\
\mathbf{0} \\
\mathbf{5} \\
0 \\
\end{array}$ & 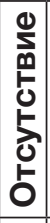 & 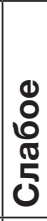 & 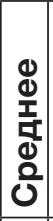 & $\begin{array}{l}0 \\
0 \\
0 \\
\mathbf{1} \\
\mathbf{0} \\
\mathbf{5} \\
0 \\
0\end{array}$ & 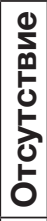 & 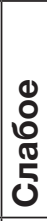 & $\begin{array}{l}\Phi \\
\frac{1}{1} \\
\frac{0}{0} \\
\Phi \\
0 \\
0\end{array}$ & 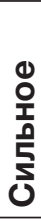 & 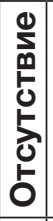 & 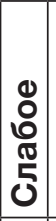 & 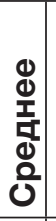 & \begin{tabular}{|l|}
0 \\
0 \\
0 \\
$\mathbf{0}$ \\
$\mathbf{0}$ \\
$\mathbf{5}$ \\
0 \\
\end{tabular} & 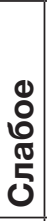 & $\begin{array}{l}\Phi \\
\Phi \\
\mathbf{1} \\
\mathbf{5} \\
\mathbf{0} \\
\mathbf{0} \\
0\end{array}$ & $\begin{array}{l}0 \\
0 \\
0 \\
\mathbf{0} \\
\mathbf{0} \\
\mathbf{5} \\
0\end{array}$ & 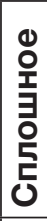 & \begin{tabular}{|l}
0 \\
0 \\
0 \\
0 \\
5 \\
5 \\
0
\end{tabular} & $\begin{array}{l}\Phi \\
\mathbf{\Phi} \\
\mathbf{1} \\
\mathbf{5} \\
\mathbf{0} \\
\mathbf{0} \\
0\end{array}$ & $\begin{array}{l}0 \\
0 \\
0 \\
0 \\
5 \\
5 \\
0 \\
0\end{array}$ & 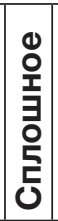 & $\begin{array}{c}0 \\
0 \\
0 \\
\mathbb{0} \\
5 \\
0\end{array}$ & 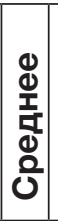 & 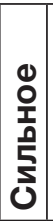 & 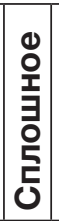 & 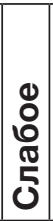 & $\begin{array}{l}\mathbf{d} \\
\mathbf{d} \\
\mathbf{1} \\
\mathbf{d} \\
\mathbf{d} \\
\mathbf{0} \\
\mathbf{U}\end{array}$ & $\begin{array}{l}0 \\
0 \\
\frac{1}{5} \\
\mathbf{5} \\
5 \\
0\end{array}$ & 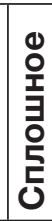 \\
\hline Мираж & + & & & & & + & & & & + & & & & & + & & & + & & & & & + & & & & & + & & & & + \\
\hline ЛК-2840 & + & & & & + & & & & & + & & & & + & & & + & & & & & + & & & & & + & & & & & + \\
\hline ЛГ-1181 & + & & & & + & & & & + & & & & & + & & & + & & & & & + & & & & & + & & & & & + \\
\hline ЛК-2704/09 & + & & & & + & & & & & + & & & & + & & & & + & & & & & + & & & & & + & & & & + \\
\hline Poкер & + & & & & + & & & & & + & & & & & + & & & + & & & & & + & & & & & + & & & & + \\
\hline ЛК-2926 & + & & & & + & & & & & + & & & & + & & & & + & & & & & + & & & & & + & & & & + \\
\hline
\end{tabular}

Эти результаты подтверждает и анализ урожайности образцов за 2018 - 2020 г. (табл. 3). Образцы ЛК-2840 и ЛГ-1181 показали себя как высокопродуктивные (средняя урожайность товарных плодов 57,9 т/га и 60,06 т/га соответственно), а сорта Мираж и Рокер низкопродуктивные (44,81 т/га и 48,59 т/га). Большие различия между урожайностью сортообразцов по годам объясняются действием не только абиотических факторов (существуют большие различия в чувствительности к тепловому стрессу внутри и между сортами), но и биотических (поражение растений болезнями и вирусами). Урожайность томата в 2019 году в связи с экстремальными погодными условиями и массовым поражением посадок вирусными и микоплазменными болезнями была невысокой и составила 16,56 - 24,72 т/га. В 2018 и 2020 годах эпифитотия не наблюдалось. Урожайность в зависимости от образца варьировала в пределах 55,8 - 73,38 т/га (2018 г) и 62,08 - 82,07 т/га (2020 г). 
Таблица 3. Урожайность сортообразцов томата, 2018 - 2020 гг.

\begin{tabular}{|c|c|c|c|c|}
\hline \multirow{2}{*}{ Образец } & \multicolumn{4}{|c|}{ Урожайность товарных плодов, т/га } \\
\hline & 2018 г. & 2019 г. & 2020 г. & Средняя \\
\hline Мираж (стандарт) & 55,80 & 16,56 & 62,08 & 44,81 \\
\hline ЛК-2840 & 72,51 & 21,75 & 79,43 & 57,90 \\
\hline ЛГ-1181 & 73,38 & 24,72 & 82,07 & 60,06 \\
\hline ЛК-2704/09 & 69,43 & 22,44 & 75,31 & 55,73 \\
\hline Pokep & 60,05 & 18,36 & 67,35 & 48,59 \\
\hline ЛК-2926 & 68,19 & 19,58 & 74,38 & 54,05 \\
\hline Средне сортовая урожайность & 66,56 & 20,58 & 74,43 & \\
\hline $\mathrm{HCP}_{05}$ & 2,12 & 1,79 & 3,20 & \\
\hline
\end{tabular}

Дисперсионный анализ полученных данных за 2018 и 2020 гг. выявил доли влияния на урожайность томата генотипической и экологической изменчивости, а так же их взаимодействие. Изучение взаимодействия между урожайностью и погодными факторами позволили установить специфику вклада в потенциальную урожайность, как генотипа сорта, так и погодных условий года. Согласно полученным данным различия урожая в системе «сорт-средаурожай» являются достоверными $\left(F_{\phi}>F_{T}\right)$ (табл. 4). Однако на изменчивость урожайности в большей степени $(78,9 \%)$ оказывают влияние сортовые особенности. Погодные условия также оказывают существенное влияние на урожайность, хотя и в меньшей степени (20,6 \%). Эффект взаимодействия погодных условий и сорта мал и составляет 0,3 \%.

Таблица 4. Результаты двухфакторного дисперсионного анализа урожайности томата $2018-2020$ гг.

\begin{tabular}{|c|c|c|c|c|c|}
\hline \multirow[b]{2}{*}{ Виды варьирования } & \multirow{2}{*}{$\begin{array}{c}\text { Число } \\
\text { степеней } \\
\text { свободы }\end{array}$} & \multirow{2}{*}{$\begin{array}{c}\text { Сумма } \\
\text { квадратов }\end{array}$} & \multirow[b]{2}{*}{ Дисперсия } & \multicolumn{2}{|c|}{ Критерий Фишера (F) } \\
\hline & & & & фактическое & табличное \\
\hline Сорт - урожайность (фактор А) & 5 & 1603,2 & 320,6 & 1776,6 & 2,6 \\
\hline Урожайность - среда (фактор В) & 1 & 418,7 & 418,7 & 2320,2 & 4,3 \\
\hline Взаимодействие & 5 & 6,3 & 1,3 & 6,9 & 2,6 \\
\hline Погрешность & 24 & 4,3 & 0,2 & & \\
\hline Общее & 35 & 2032,5 & & & \\
\hline
\end{tabular}

\section{Выводы}

Анализ сложившихся погодных условий в регионе за 2018 - 2020 гг. показал необходимость создания сортов и гибридов томата с повышенной устойчивостью к стрессовым условиям, одним из которых является высокая температура в период цветения и налива плодов.

По результатам лабораторных исследований выявлены сортообразцы, обладающие повышенной жароустойчивостью растений (ЛК-2840, ЛГ-1181), слабую органическую жаростойкость проявили сорта Мираж и Рокер.

\section{ЛИТЕРАТУРА}

1. Бюллетень метеостанции. Ежемесячные бюллетени с метеоданными агрометеорологической станции Краснодар - Круглик. - Краснодар, 2018 - 2020 гг.

2. Генкель, П.А. О новом лабораторном способе диагностики жаро- и засухоустойчивости для селекци / П.А.Генкель, К.А Баданова., В.В. Левина // Физиология растений. - М.: Наука, - 1970. - Т. 17. - С. 431 - 435.

3. Грушанин, А.И. Технология выращивания томата в открытом грунте на Кубани: рекомендации / А.И. Грушанин, Л.В. Есаулова, др. - Краснодар, 2016. - 36 с.

4. Дзюба, В.А. Многофакторные опыты и методы биометрического анализа экспериментальных данных: Методическое пособие / В.А. Дзюба. - Краснодар, 2007. - 76 с.

5. Король, В.Г. Агробиологические основы повышения эффективности производства овощей в зимних теплицах / В.Г. Король. - М., 2011. - 42 с.

6. Кошкин, Е.И. Физиология устойчивости сельскохозяйственных культур: учебник / Е.И. Кошкин. - М.: ООО «Дрофа», 2010. $-638 \mathrm{c}$.

7. Литвинов, С.С. Методика опытного дела в овощеводстве / С.С. Литвинов. - М.: Россельхозакадемия, 2011. $648 \mathrm{c.}$ 
8. Мацков, Ф.Ф. Распознавание живых, мертвых и повреждённых хлорофиллоносных тканей растений по реакции образования феофитина при оценке устойчивости к экстремальным воздействиям / Ф.Ф. Мацков. - Л.: Колос, 1976. - С. $55-60$.

9. Федулов, Ю.П. Методы определения устойчивости растений: Курс лекций / Ю.П.Федулов. - Краснодар: КубГАУ, 2015. - 39 c.

10. Шеуджен, А.Х. Методика агрохимических исследований и статистическая оценка их результатов / А.Х. Шеуджен, Т.Н. Бондарева. - Майкоп: ОАО «Полиграф-ЮГ», 2015. - 664 с.

11. Golam, F. Heat tolerance in tomato / F. Golam et al. - Life Science Journal, 2012. - V. 9. - 4. - P. 1936 - 1950.

12. Hasanuzzaman, M. Physiological, biochemical, and molecular mechanisms of heat stress tolerance in plants / Hasanuzzaman M. et al. - International journal of molecular sciences, 2013. - V. 14. - 5. - P. $9643-9684$.

13. Hazra, P. et al. Breeding tomato (Lycopersicon esculentum Mill) resistant to high temperature stress / P. Hazra et al. International Journal of Plant Breeding, 2007. - V. 1. - 1. - P. $31-40$.

14. Li, T. Effect of short-term daytime sub-high temperature stress on photosynthesis of tomato leaves / T. Li, M. Li. Transactions of the Chinese Society of Agricultural Engineering, 2009. - V. 25. - 9. - P. $220-225$.

15. Qu, A. L. Molecular mechanisms of the plant heat stress response / A. L. Qu et al. - Biochemical and biophysical research communications, 2013. - V. 432. - 2. - P. 203-207.

16. Sánchez-Rodríguez, E. Genotypic differences in some physiological parameters symptomatic for oxidative stress under moderate drought in tomato plants / E. Sánchez-Rodríguez et al. - Plant science, 2010. - V. 178. - 1. - P. 30 - 40.

17. Wen, J. et al. Identification of heat-tolerance QTLs and high-temperature stress-responsive genes through conventional QTL mapping, QTL-seq and RNA-seq in tomato / J. Wen et al. - BMC plant biology, 2019. - T. 19. - 1. - P. 398.

\section{REFERENCES}

1. Bulletin of the weather station. Monthly bulletins with meteorological data of the agrometeorological station Krasnodar - Kruglik, Krasnodar 2018 - 2020.

2. Genkel, P.A. On a new laboratory method for the diagnosis of heat and drought resistance for breeding. / Genkel P.A., Badanova K.A., Levina V.V. // Plant Physiology. volume 17, Iss. 2 - M, "Science", 1970. - P. 431 - 435.

3. Grushanin, A.I. Technology of growing tomatoes in the open ground in the Kuban. Recommendations / Grushanin A.I., Esaulova L.V., et al. - Krasnodar, 2016. - 36 p.

4. Dzyuba, V.A. Multifactorial experiments and methods of biometric analysis of experimental data.// Methodical guidelines. - Krasnodar, 2007. - 76 p. Recommendations. - Krasnodar, 2009. - 26 p.

5. Korol, V.G. Agrobiological basis for increasing the efficiency of vegetable production in winter greenhouses: Abstract of Dr. thesis: 06.01.01 / Korol V.G. - M., 2011. - 42 p.

6. Koshkin, E.I. Physiology of stability of agricultural crops: textbook / E.I. Koshkin. - M.: Drofa, 2010. - 638 p. : ill. - (Textbooks for students of higher educational institutions). - ISBN 978-5-358-07798-0.

7. Litvinov, S.S. Experimental methodology in vegetable growing. / S.S. Litvinov. - M., 2011. - 648 p.

8. Matskov, F.F. Recognition of living, dead and damaged chlorophyll-bearing plant tissues by the reaction of pheophytin formation when assessing resistance to extreme impacts. / F.F. Matskov. - Leningrad, "Kolos", 1976. - P. 55 - 60.

9. Fedulov, Yu.P. Methods for determination of plant resistance / course of lectures, Yu. P. Fedulov - Krasnodar: KubSAU. - 2015. - 39 p.

10. Sheudzhen, A.Kh. Agrochemical research methods and statistical evaluation of their results / A.Kh. Sheudzheen, T.N. Bondareva. - Maykop: JSC "Polygraph-YUG", 2015. - 664p.

11. Golam F. et al. Heat tolerance in tomato // Life Science Journal. - 2012. - V. 9. - 4. - P. 1936 - 1950.

12. Hasanuzzaman M. et al. Physiological, biochemical, and molecular mechanisms of heat stress tolerance in plants // International journal of molecular sciences. - 2013. - V. 14. - 5. - P. $9643-9684$.

13. Hazra P. et al. Breeding tomato (Lycopersicon esculentum Mill) resistant to high temperature stress // International Journal of Plant Breeding. - 2007. - V. 1. - 1. - P. $31-40$.

14. Li T., Li M. Effect of short-term daytime sub-high temperature stress on photosynthesis of tomato leaves // Transactions of the Chinese Society of Agricultural Engineering. - 2009. - V. 25. - 9. - P. 220 - 225.

15. Qu A.L. et al. Molecular mechanisms of the plant heat stress response //Biochemical and biophysical research communications. - 2013. - V. 432. - 2. - P. $203-207$.

16. Sánchez-Rodríguez E. et al. Genotypic differences in some physiological parameters symptomatic for oxidative stress under moderate drought in tomato plants // Plant science. - 2010. - V. 178. - 1. - P. $30-40$.

17. Wen J. et al. Identification of heat-tolerance QTLs and high-temperature stress-responsive genes through conventional QTL mapping, QTL-seq and RNA-seq in tomato // BMC plant biology. - 2019. - V. 19. - 1. - P. 398.

\author{
Ирина Викторовна Козлова \\ Научный сотрудник отдела \\ овощекартофелеводства \\ E-mail: k.irina1967@mail.ru \\ Все: ФГБНУ «ФНЦ риса», \\ 350921, Краснодар, пос. Белозерный 3
}

\section{Irina Viktorovna Kozlova}

Research associate of the Department

vegetable and potato growing

E-mail: k.irina1967@mail.ru

ALL: 3, Belozerny, Krasnodar, 350921, Russia 


\section{ПРИМЕНЕНИЕ ВТОРИЧНОЙ ЦЕЛЛЮЛОЗЫ В КАЧЕСТВЕ МУЛЬЧИРУЮЩЕГО МАТЕРИАЛА НА ЛЕТНИХ ПОСЕВАХ ДЫНИ СОРТА СТРЕЛЬЧАНКА}

Целью проводимого эксперимента было определение эффективности применения мульчирования почвы вторичной целлюлозой на посевах дыни для снижения потери влаги от испарения, подавление роста сорняков и защиты корневой системы от перегрева. Опыты закладывались согласно общепринятой методике по Литвинову С.С. На летних посевах дыни сорта Стрельчанка изучено использование вторичной целлюлозы для мульчирования почвы. Получены результаты по температурному балансу на поверхности почвы и в зоне залегания основной массы корней. Под мульчирующим материалом температура почвы всегда оставалась ниже в среднем на 3,3 ${ }^{\circ} \mathrm{C}$. Отмечена эффективность применения мульчирующего материала в сглаживании температурных колебаний, защите корневой системы растений от перегрева и создании благоприятных условий по увлажнению почвы. Мульча из вторичной целлюлозы препятствовала испарению поливной влаги и обеспечивала подавление роста сорняков, исключая необходимость проведения прополки в рядках. Анализ полученных результатов, показал достоверное увеличение урожайности плодов дыни на 0,93 т/га (+15,9 \%) в сравнении с контрольным вариантом, на котором применяли стандартную технологию. Мульчирование способствовало увеличению накопления сухих растворимых веществ в мякоти плодов дыни. Для снижения расхода вторичной целлюлозы и создание равномерного мульчирующего слоя необходимо тщательное выравнивание почвы. После уборки и удаления капельной ленты мульча из вторичной целлюлозы не создавала препятствий для проведения агротехнических мероприятий по обработке почвы. Целлюлоза, оставаясь на участке после обработки почвы обеспечивала улучшение агрофизических свойств почвы.

Ключевые слова: мульчирующий материал, вторичная целлюлоза, дыня, температура, урожайность.

\section{THE USE OF RECYCLED CELLULOSE AS A MULCHING MATERIAL IN SUMMER CROPS OF STRELCHANKA MELON}

The purpose of the experiment was to determine the effectiveness of mulching the soil with secondary cellulose on melon crops to reduce moisture loss from evaporation, suppress weed growth and protect the root system from overheating. The experiments were carried out according to the generally accepted methodology according to S.S. Litvinov. The use of recycled cellulose for soil mulching was studied on summer crops of the Strelchanka variety. The results were obtained on the temperature balance on the soil surface and in the zone of occurrence of the main mass of roots. Under the mulching material, the soil temperature has always remained lower by an average of $3.3^{\circ} \mathrm{C}$. The effectiveness of the use of mulching material in smoothing temperature fluctuations, protecting the root system of plants from overheating and creating favorable conditions for soil moisture is noted. Recycled cellulose mulch resisted evaporation of irrigation moisture and provided suppression of weed growth, eliminating the need for weeding in rows. The analysis of the results obtained showed a significant increase in the yield of melon fruits by 0.93 t/ha (+15.9\%) in comparison with the control option, which used the standard technology. Mulching increased the accumulation of dry soluble substances in the melon fruit pulp. To reduce the consumption of recycled cellulose and create a uniform mulch layer, careful leveling of the soil is necessary. After harvesting and removing the drip tape, the mulch from recycled cellulose did not create obstacles for carrying out agrotechnical measures for tillage. Cellulose, remaining on the site after tillage, improved the agrophysical properties of the soil.

Key words: mulching material, recycled cellulose, melon, temperature, and yield.

\section{Введение}

Мульчирование почвы в открытом грунте, при выращивании овощных культур, является одним из наиболее эффективных агротехнологических методов, способствующих созданию более благоприятного тепловлажностного режима почвы и предпочвенного слоя воздуха, улучшению физических свойств почвы и усилению биохимических процессов в ней. Одновременно с этим мульча угнетает и ограничивает рост и развитие сорняков.
Мульчирование почвы как агротехнический прием применяют давно. В качестве мульчирующего материала используют солому, торф, сухие листья, опилки, навоз, специальную мульчбумагу, синтетические пленки и другие материалы. Покрытие поверхности почвы мульчей позволяет в зависимости от ее физико-механических свойств разнообразно воздействовать на весь комплекс факторов, определяющих физические условия в почве. Подбирая мульчирующие материалы с определенными физико-механическими и оптическими характеристиками, можно активно 
влиять на режим температуры и влажности почвы, уменьшать или аккумулировать величину солнечной радиации [1, 2]. В последнее время производители овощной продукции используют полимерную пленку, основным недостатком которой является значительный период распада и как следствие засорение полей. Выполнение послеуборочных мероприятий по удалению пленки с участков затруднено из-за растительных остатков. Пленка цепляется и наматывается на рабочие органы сельскохозяйственных орудий, снижая качество проводимых агромероприятий [2, 3]. Создаются и рекомендуются к применению новые мульчирующие материалы, отвечающие современным требованиям сельхозпроизводителей. Одним из таких материалов является вторичная целлюлоза.

\section{Цель исследований}

Выявить эффективность применения мульчирования почвы вторичной целлюлозой на посевах дыни сорта Стрельчанка.

\section{Материалы и методы}

Производственный опыт проводили на селекционно-семеноводческом участке овощебахчевых культур ФГБНУ «ФНЦ риса» на летнем посеве дыни раннеспелого сорта Стрельчанка, с периодом вегетации 55 - 58 дней от всходов до уборки. Учетная

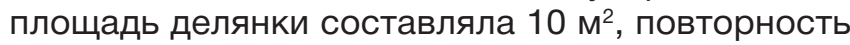
в опыте трехкратная. Расположение вариантов рендомизированное. Площадь питания одного растения -2 м $^{2}(2,0 \times 1,0)$. Посев осуществлен семенами категории ОС, вручную 15 июля, на участке после уборки чеснока. На делянку высевалось 5 г семян. Густота посева из расчета 5 тыс. штук растений на гектар. Минеральное удобрение нитроаммофоску $\left(\mathrm{N}_{16} \mathrm{P}_{16} \mathrm{~K}_{16}\right)$ вносили до посева перед фрезерованием почвы. Норма внесения минеральных удобре- ний $\mathrm{N}_{60} \mathrm{P}_{60} \mathrm{~K}_{60}$ кг д. в./га (по 375 кг/га физических туков). Для обеспечения всходов при летнем посеве укладывали капельную ленту с расстоянием между эмиттерами 35 см. Для мульчирования почвы использовали вторичную целлюлозу, которая состоит на 70 \% из измельченной целлюлозы серо-белого цвета и на 30 \% из кальция с рН - 7,6. Насыпная плотность материала 450 - 540 кг/м³. Период полного разложения вторичной целлюлозы 11 - 15 месяцев. Через 5 дней после посева, когда появились всходы, мульчирующий материал наносили на почву по центру посевного ряда. Ширина мульчирующей полосы 0,5 м и толщина слоя до 5 см, которая обеспечивала полное покрытие почвы. Растения в момент нанесения мульчи закрывали полиэтиленовыми стаканами.

При закладке опытов и проведении исследований использовали методику полевого опыта в овощеводстве [4]. Агротехнику выращивания бахчевых культур на опытных участках выполняли в соответствии с рекомендациями, разработанными в отделе овощекартофелеводства ФГБНУ «ФНЦ риса» [5]. Статистическая обработка полученных данных проведена согласно методическим рекомендациям А.Х. Шеуджена [6].

\section{Результаты и обсуждение}

Температурный режим верхнего слоя почвы формируется под воздействием трансформации и перераспределении солнечной энергии. При нагревании поверхности происходит теплоотдача в почву. Интенсивность теплообмена зависит от теплофизических характеристик почвы и состояния ее поверхности (влажности, микрорельефа, укрытие мульчирующим материалом и др.) Некоторая часть энергии уходит на тепловое излучение поверхности почвы и затрачивается на испарение влаги [1, 7 - 10].

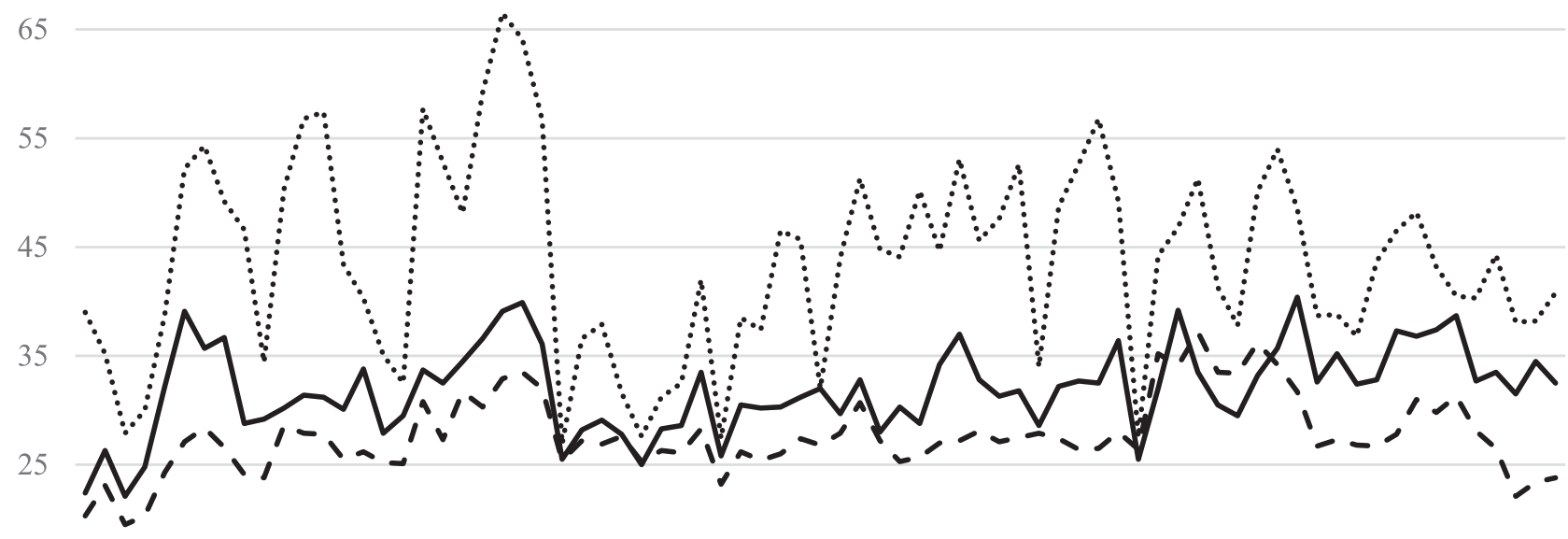

15

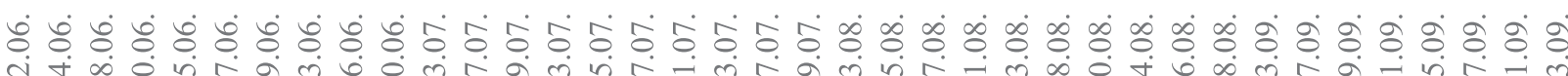

잉 0 음

$$
\longrightarrow \mathrm{t}^{\circ} \text { воздуха } \quad \cdots . . . . . \mathrm{t}^{\circ} \text { на поверх. почвы } \quad-\quad-\mathrm{t}^{\circ} \text { почвы на гл. } 10 \mathrm{~cm}
$$

Рисунок 1. Динамика температуры воздуха и почвы в контрольном варианте 


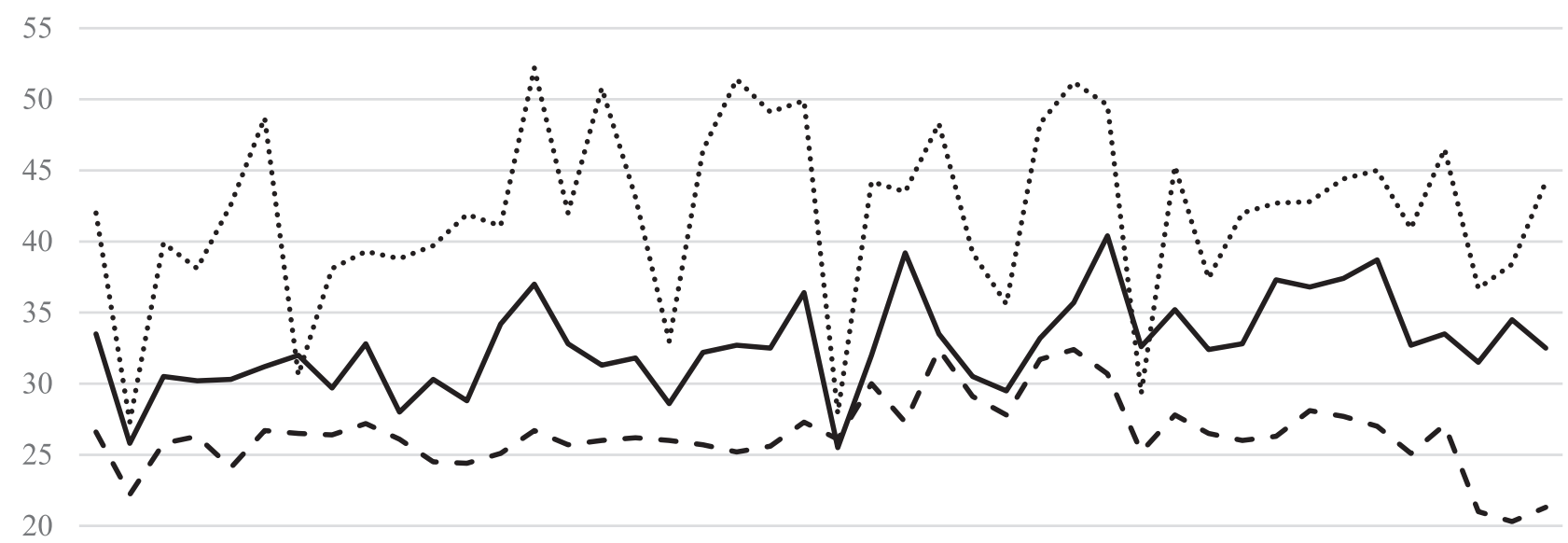

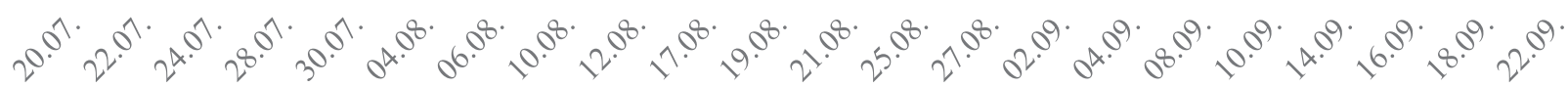

$$
\text { — } \mathrm{t}^{\circ} \text { воздуха } \quad \text { …...... } \mathrm{t}^{\circ} \text { поверх. мульчи } \quad \text { - }--\mathrm{t}^{\circ} \text { почвы на гл. } 15 \text { см мульча }
$$

Рисунок 2. Динамика температуры воздуха и почвы при использовании мульчирующего покрытия из вторичной целлюлозы

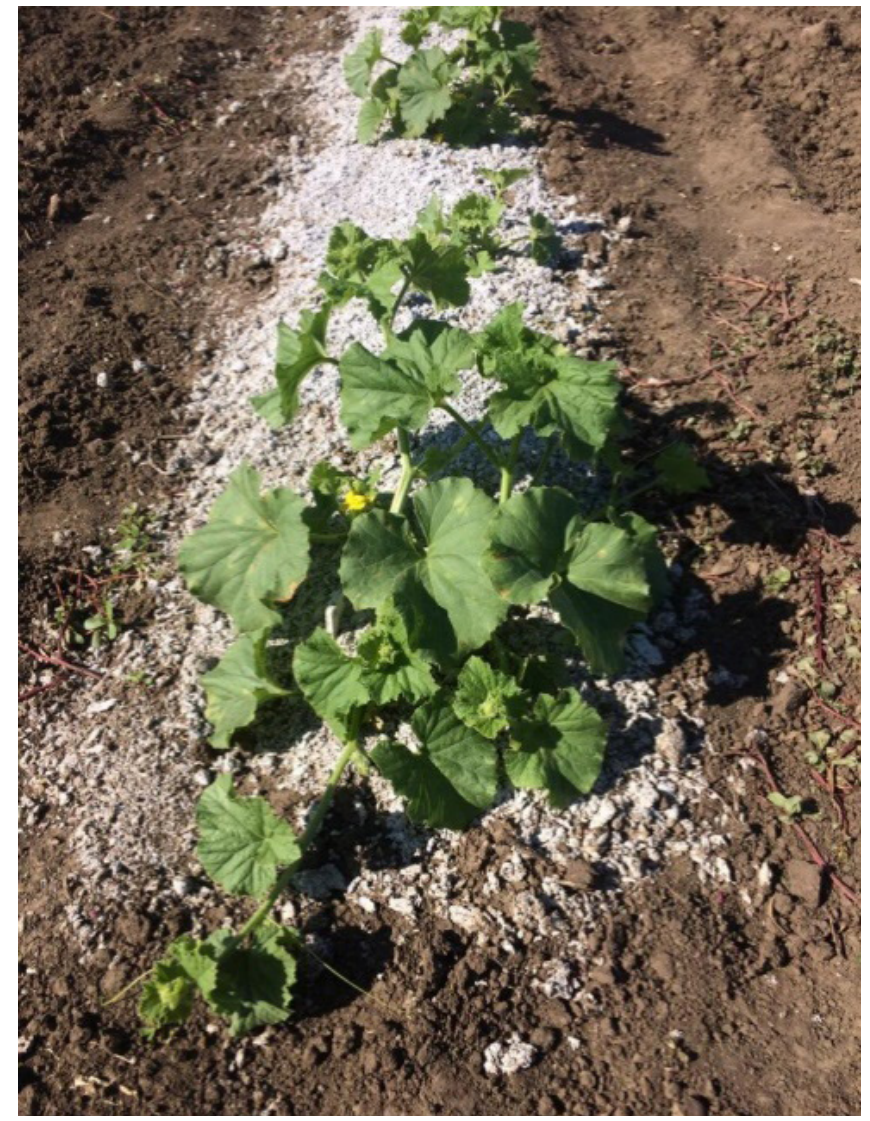

Рисунок 3. Начало цветения дыни сорта Стрельчанка, 06.08.2020

Результаты измерения температуры воздуха и почвы представлены на графиках (рис. 1, 2). Наблюдения показали, что поверхность почвы нагревалась сильнее, чем поверхность мульчирующего слоя. В ясные безоблачные дни разница доходила

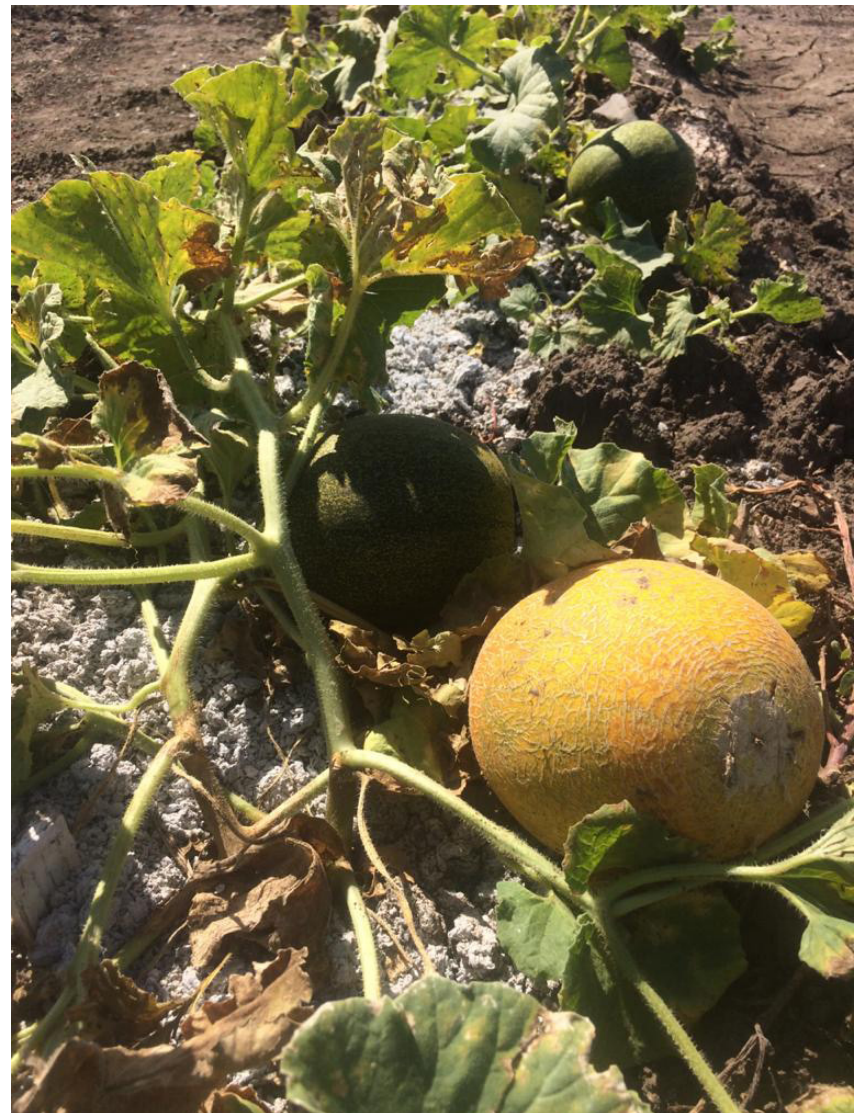

Рисунок 4. Начало созревания дыни сорта Стрельчанка, 13.09.2020

до $10{ }^{\circ} \mathrm{C}$, благодаря отражению света от серо-белой поверхности мульчирующего материала. Однако почва под мульчей на глубине 10 см всегда оставалась менее прогретой, разница доходила до $3,3^{\circ} \mathrm{C}$ и имела меньшую амплитуду колебания температуры, так 
как значительная часть тепла отражалась от поверхности мульчирующего слоя. Мульчирующий экран защищал от перегрева зону размещения основной массы корней. За первый месяц периода вегетации под мульчей корневая система испытала температурную нагрузку меньше на $63^{\circ} \mathrm{C}$. В июле среднемесячная температура почвы на глубине 10 см под мульчей была $25,8^{\circ} \mathrm{C}$, в контрольном варианте $28,0^{\circ} \mathrm{C}$. В августе на корни воздействовало суммарного тепла на $49,6{ }^{\circ} \mathrm{C}$ меньше. Среднемесячная температура в августе под мульчирующим слоем $26,7^{\circ} \mathrm{C}$, в контрольном варианте $-29,0^{\circ} \mathrm{C}$. Мульча обеспечивала более комфортный для корневой системы температурный режим и защищала от перегрева. Исключалось испарение поливной влаги с поверхности почвы, что существенно влияло на влагообеспеченность растений. Мульчирующий слой бумаги полностью подавлял рост сорняков, исключая прополку в рядках (рис. 3, 4).
Создание оптимальных условий в среде обитания растений, оптимизация параметров агрофитоценоза и его эффективного функционирования, в конечном счете, приводит к реализации потенциальной биологической продуктивности используемых сортов и гибридов [1, 2]

Под мульчирующим слоем вторичной целлюлозы корневая система растений дыни меньше подвергалась температурному перегреву. Мульча способствовала сохранению влаги в почве и сдерживала развитие сорняков. Созданные условия обеспечили формирование большего количество плодов на одном растении и с большей массой (см. табл.). В итоге урожайность, при использовании мульчирующего материала, составила 6,76 т/га и превысила контроль на 15,9 \%. Следует отметить, что применение мульчи способствовало большему накоплению сухих растворимых веществ (CPB) в мякоти плодов. После уборки и удаления капельной ленты мульчирующий слой вторичной целлюлозы не создавал препятствий при обработке почвы.

Таблица. Влияние мульчирования почвы вторичной целлюлозой на урожайность раннеспелого сорта дыни Стрельчанка

\begin{tabular}{|c|c|c|c|c|c|}
\hline \multirow[b]{2}{*}{ Вариант } & \multirow{2}{*}{$\begin{array}{c}\text { Кол-во плодов } \\
\text { на } 1 \text { растении, шт. }\end{array}$} & \multirow{2}{*}{$\begin{array}{c}\text { Масса } 1 \text { плода } \\
\text { (среднее), кг }\end{array}$} & \multicolumn{2}{|c|}{ Урожайность, } & \multirow[b]{2}{*}{ СРВ, мг/\% } \\
\hline & & & т/га & $\begin{array}{c}\text { прибавка } \\
\text { к контролю, \% } \\
\end{array}$ & \\
\hline Контроль & 2,0 & 2,15 & 5,83 & - & 11,0 \\
\hline Мульча & 2,4 & 2,44 & 6,76 & 15,9 & 12,3 \\
\hline
\end{tabular}

\section{Выводы}

1. Мульчирование почвы вторичной целлюлозой защищает корневую систему от перегрева и сглаживает колебания температуры в почве, препятствует испарению влаги и подавляет рост сорняков, исключая необходимость проведения прополки в рядках.

2. Применение вторичной целлюлозы создало оптимальные условия для корневой системы дани, вследствие чего на растении сформировалось больше плодов с большей массой. В итоге был собран урожай плодов на 0,93 т/га больше, чем в контрольном варианте.

3. После завершения уборки и удаления капельной ленты вторичная целлюлоза не создавала препятствий для применения механизированной обработки почвы.

4. Для уменьшения расхода вторичной целлюлозы при создании мульчирующего слоя, необходимо тщательно выравнивать поверхность почвы.

\section{ЛИТЕРАТУРА}

1. Микаелян, Г.А. Основы оптимального проектирования производственных процессов в овощеводстве / Г.А. Микаелян, Р.Д. Нурметов. - М.: ФГНУ «Росинформагротех», 2005. - 640 с.

2. Королёва, С.В. Применение мульчирующей черной полимерной биоразрушаемой пленкой фирмы BASF на овощебахчевых культурах / С.В. Королёва, В.Э. Лазько, И.В. Козлова, О.В. Якимова, Н.В. Шуляк // Рисоводство. - Краснодар, 2020. - № 1(46). - С. 71 - 77.

3. Гиш, Р.А. Овощеводство юга России: учебник / Р.А. Гиш, Г.С. Гикало. - Краснодар: ЭДВИ, 2012. - 632 с.

4. Литвинов, С.С. Методика опытного дела в овощеводстве / С.С. Литвинов - М., 2011. - 648 с.

5. Цыбулевский, Н.И. Бахчевые культуры (рекомендации) / Н.И. Цыбулевский, Е.М. Кулиш, Л.А. Шевченко. Краснодар: 2009. - 34 с.

6. Шеуджен, А.Х. Агрохимические основы применения удобрений / А.Х. Шеуджен, Т.Н. Бондарева, С.В. Кизинек. - Майкоп: Полиграф-Юг, 2013. - 271 с.

7. Гончарук, Н.С. Полимеры в овощеводстве / Н.С. Гончарук. - М.: Колос, 1971. - 264 с.

8. Тооминг, Х.Т. Солнечная радиация и формирование урожая. / Х.Т. Тооминг. - Л.: Гидрометеоиздат, 1977. $-100 \mathrm{c}$. 
9. McGree, R.J. Practical applications of action spectra. In Light and Plant development. / R.J. McGree // Ed.H. Smith. Butterworths, 1986. -515 p.

10. Jurik, T.W. Ontogeny of photosynthetic performance in Fragaria vegrinata under changing light regime. / T.W. Jurik , J.F. Chabot //Plant Physiol. - 1979.

\section{REFERENCES}

1. Mikaelyan, G.A. Fundamentals of optimal design of production processes in vegetable growing / G.A. Mikaelyan, R.D. Nurmetov. - M .: FGNU "Rosinformagrotech", 2005. - 640 p.

2. Koroleva, S.V. Application of BASF mulching black polymer biodegradable film on vegetable and melon crops / S.V. Korolev, V.E. Lazko, I.V. Kozlova, O.V. Yakimova, N.V. Shulyak // Rice farming. - Krasnodar, 2020. - № 1(46). - P. 71 - 77.

3. Guiche, R.A. Vegetable growing of the south of Russia: textbook / R.A. Guiche, G.S. Gikalo. - Krasnodar: EDVI, 2012. $632 \mathrm{p}$.

4. Litvinov, S.S. Experimental methodology in vegetable growing / S.S. Litvinov - M., 2011. - 648 p.

5. Tsybulevsky, N.I. Melons cultures (recommendations) / N.I. Tsybulevsky, E.M. Kulish, L.A. Shevchenko. - Krasnodar: 2009. -34 p.

6. Sheujen, A.Kh. Agrochemical basis for the application of fertilizers / A.Kh. Sheujen, T.N. Bondareva, S.V. Kizinek. Maykop: Polygraph-Yug, 2013. - 271 p.

7. Goncharuk, NS Polymers in vegetable growing / N.S. Honcharuk. - M.: Kolos, 1971. - 264 p.

8. Tooming, H.T. Solar radiation and crop formation. / H.T. Tooming. - L.: Gidrometeoizdat, 1977. - 100 p.

9. McGree, R.J. Practical applications of action spectra. In Light and Plant development. / R.J. McGree // Ed.H. Smith. Butterworths. 1986. $-515 \mathrm{p}$.

10. Jurik, T.W. Ontogeny of photosynthetic performance in Fragaria vegrinata under changing light regime. / T.W. Jurik, J.F. Chabot // Plant Physiol. - 1979.

\section{Виктор Эдуардович Лазько}

Ведущий научный сотрудник лаборатории бахчевых и луковых культур

E-mail: lazko62@mail.ru

\section{Ольга Владимировна Якимова}

Научный сотрудник лаборатории

бахчевых и луковых культур

E-mail: belyaeva12092013@yandex.ru

Bсе: ФГБНУ «ФНЦ риса»

350921, г. Краснодар, пос. Белозерный, 3

\section{Victor E. Lazko}

Leading researcher of the laboratory of melon and onion crops

E-mail: lazko62@mail.ru

\section{Olga V. Yakimova}

Researcher of the laboratory

of melon and onion crops

E-mail: belyaeva12092013@yandex.ru

All: FSBSI "FSC of rice"

3, Belozerny, Krasnodar, 350921, Russia 


\section{ЭКОНОМИЧЕСКАЯ ЭФФЕКТИВНОСТЬ ПРОИЗВОДСТВА ТОВАРНОГО ЧЕСНОКА НА ПРИМЕРЕ ОДНОГО ИЗ ХОЗЯЙСТВ КРАСНОДАРСКОГО КРАЯ}

Представлен экономический анализ производства товарного чеснока на примере хозяйства «Прогресс» Краснодарского края, в котором ежегодно под выращивание озимого чеснока занята площадь от 500 до 800 га. Чеснок выращивается в однолетней и двухлетней культуре. В однолетней культуре для посадки используется зубок. Норма высадки на один гектар от 600 до 1500 кг, в зависимости от размера. Из-за высокой цены на посадочный материал и большой нормы высадки, производственные затраты вместе с налогами составляют более 500 тыс. рублей на один гектар. Рентабельность выращивания озимого чеснока составляет 54 \%. Выход товарных луковиц при данном способе выращивания не превышает 70 \%, из-за неправильной ориентации зубков в почве при посадке. Снижается урожайность и товарность из высаженных боком или перевернутых к верху донцем зубков, из которых формируются однобокие мелкие луковицы. При двухлетнем выращивании в качестве посадочного материала используют воздушные луковицы. Производственные затраты значительно ниже и раздроблены на два года, благодаря минимальным расходам на посадочный материал. В первый год выращивания формируется однозубковая луковица ориентированная вертикально в почве, которую оставляют в зиму без пересадки. Выход товарных луковиц более 80 \%. Основной проблемой при двухлетнем выращивании является борьба с сорняками. Рентабельность выращивания чеснока из воздушных луковиц без пересадки составляет 174,4 \%, но участок под культурой занят два года. В хозяйстве организована посадка культуры чеснока таким образом, что урожай чеснока получают в каждый сельскохозяйственный сезон, при этом используют оба способа выращивания.

Ключевые слова: озимый чеснок, зубки, воздушные луковицы, однолетнее и двухлетнее выращивание, экономическая эффективность, рентабельность производства.

\section{ECONOMIC EFFICIENCY OF COMMERCIAL GARLIC PRODUCTION ON THE EXAMPLE OF ONE OF THE FARMS IN THE KRASNODAR TERRITORY}

An economic analysis of the production of commercial garlic is presented on the example of the farm "Progress" of the Krasnodar Territory, in which an area from 500 to 800 hectares is occupied annually under the cultivation of winter garlic. Garlic is grown in annual and biennial crops. In an annual culture, a clove is used for planting. The planting rate per hectare is from 600 to $1500 \mathrm{~kg}$, depending on the size. Due to the high price of planting material and a large planting rate, production costs, including taxes, amount to more than 500 thousand rubles per hectare. The profitability of growing winter garlic is $54 \%$. The yield of marketable bulbs with this method of cultivation does not exceed $70 \%$, due to the wrong orientation of the cloves in the soil during planting. The yield and marketability from the cloves planted sideways or turned upside down to the top, from which one-sided small bulbs are formed, are reduced. For two-year cultivation, air bulbs are used as planting material. Production costs are significantly lower and split over two years due to the minimum costs of planting material. In the first year of cultivation, a single-toothed bulb is formed with a vertical orientation in the soil, which is left in the winter without replanting. The output of marketable bulbs is more than $80 \%$. The main problem with two-year cultivation is weed control. The profitability of growing garlic from aerial bulbs without replanting is $174.4 \%$, but the area under the crop has been occupied for two years. The farm organizes the planting of a garlic crop in such a way that the harvest of garlic is obtained in each agricultural season, while using both methods of cultivation.

Key words: winter garlic, chives, air bulbs, one-year and two-year cultivation, economic efficiency, profitability of production.

\section{Введение}

Производство чеснока в мире непрерывно растет. Сейчас его ежегодно выращивают около 10 млн тонн при средней урожайности 10 тонн с гектара.

В мировом рейтинге лидером по экспорту чеснока является Китай (81,16 \%). По данным FAOSTST в Европейском рейтинге лидером по валовому производству чеснока является Испания с 49,43 \% (173 600 т). За ней следуют Румыния
$(24,43 \%)$, Италия (10,78 \%) и Франция (6,78 \%) [11]. В Российской Федерации под производством чеснока занята площадь - 93,5 тыс. га. Вся получаемая продукция остаётся на внутреннем рынке для удовлетворения потребности населения и не идёт на экспорт [10].

Производство чеснока совершенно не удовлетворяет потребности в нем, поэтому он в больших количествах закупается в Китае, Индии, Египте, Средней 
Азии. Привозной чеснок плохо хранится и зачастую имеет низкие вкусовые качества.

В структуре производства овощной продукции в Краснодарском крае чеснок занимает особое место. За последний период площади посевов и сбор валовой продукции чеснока начинают увеличиваться. По данным ИКЦ за 2020 год наибольшие площади посадки чеснока занимают личные подсобные хозяйства (ЛПХ) - 1050,3 га, сельхозорганизации - 457, 4 га, крестьянско-фермерские хозяйства (КФХ) в крае занимают всего 53,02 га. Фактически убрано чеснока в Краснодарском крае в 2020 году - 1560,72 га, средняя урожайность составила - 8,8 т/га, максимальный урожай луковиц был собран в КФХ 9,8 т/га. Самый низкий урожай был собран на участках ЛПХ - 7,43 т/га [6]. Дефицит производства чеснока в крае носит ярко выраженный характер, что связано с трудоемкостью культуры, с отсутствием специализированной техники, высокопродуктивных сортов, невысокой урожайностью и сложностью семеноводства. Успех выращивания озимого чеснока в Краснодарском крае зависит от погодно-климатических факторов, использования сортов, устойчивых к температурным стрессам и адаптивных к почвенным условиям зон выращивания, а также осуществления агротехнических приемов, способствующих перезимовке растений и повышению урожайности $[1,3,5,8]$.

Для продвижения культуры и расширения объемов производства чеснока необходимо организовывать демонстрационные площадки и проводить обучающие семинары в помощь фермерам и главам личных подсобных хозяйств на базе передовых хозяйств края и опираясь на достоверный опыт. Кроме технологии выращивания чеснока, в таких хозяйстве можно еще ознакомиться с экономическими выкладками по производству озимого чеснока.

\section{Цель исследований}

Показать экономическую эффективность производства товарного чеснока при однолетнем и двухлетнем выращивании на примере хозяйства «Прогресс» Крыловского района Краснодарского края.

\section{Материалы и методы}

Анализ производственной деятельности был сделан в хозяйстве «Прогресс» Крыловского района Краснодарского края по технологическим картам и производственным отчетам за 3 года.

\section{Результаты и обсуждение}

В хозяйстве ежегодно под выращиванием чеснока занято от 500 до 800 гектар. Чеснок выращивают в озимой культуре в основном на богарных участках, в однолетней и двухлетней культуре без пересадки. Производственный сектор полностью укомплектован тракторами и сельскохозяйственными орудиями, необходимыми для выполнения всего регламента агромероприятий: подготовке почвы, посадке, уходу за растениями и почвой в период вегетации, уборочные комбайны и другие. Высаживают зубками и воздушными луковичками трех-четырех строчными лентами с расстоянием в ряду между растениями от 5 до 10 см. Норма высадки зависит от размера посадочного материала: зубками от 600 до 1500 кг/га, воздушными луковичками от 25 до 35 кг/га. При выращивании из зубка, высаженные с осени зубки, в первой половине лета дают урожай луковиц. Выращивание чеснока из воздушных луковичек дает урожай через два года. В основном выращивают сорта стрелкующегося чеснока Любаша и Добрыня. При механизированной посадке значительная часть зубков оказывается боком или перевернутые вверх донцем. Из таких зубков формируются нетоварные луковицы, что сказывается на урожайности. Объем выбракованных луковиц составлял около 25 - 30 \% от общего урожая.

Для удобства расчет экономической эффективности выращивания озимого чеснока производился на 1 га. Для анализа использовали усредненные данные технологических карт и другие расходные документы в хозяйстве за последние три года. При расчете брали норму высадки крупного зубка 1500 кг/га. Цена посадочного материала категории элита - 150 руб./кг. За период проведения анализов средняя урожайность товарного чеснока в хозяйстве составила 15 тонн/га.

Опираясь на средние цены аренды земли в Краснодарском крае, стоимость аренды 1 га обходилась в 12 тысяч рублей. В структуру производственных затрат при выращивании чеснока вошли также расходы, связанные с приобретением посадочного материала, предпосевной и основной обработкой почвы, затраты на приобретение удобрений и средств защиты растений, а также затраты на посадку, уход и уборочные работы. Сумма затрат по каждому технологическому этапу рассчитана исходя из затрат на оплату труда наемных работников и при необходимости найма техники. Итого производственные затраты, с учетом стоимости аренды земли на 1 га в среднем за три года составила 342 тысячи 00 рублей (табл.1).

Ежегодно на приобретение посадочного материала затраты составляли более 80 \%, на уборку и обрезку урожая - до $10 \%$, остальное на аренду земли, подготовку почвы к посадке. Таким образом основная доля затрат при выращивании через зубок приходилась на закупку посадочного материала 225000 рублей.

Средняя урожайность чеснока в хозяйстве составляла 15 тонн, при условии правильного ухода и отсутствия негативных факторов погоды, таких как заморозки, чередующиеся с оттепелями и высокие температуры в период активного роста луковицы. Доход от продажи урожая зависел от его качества и коммерческого объема. В хозяйстве ежегодно под озимым чесноком занята площадь от 500 до 800 га и более. При большом объеме продукции и возможности заключать контракты на регулярные поставки крупным потребителям у хозяйства была возмож- 
ность регулировать и удерживать стабильную цену на чеснок. Скупщики закупали чеснок по цене от 70 до 90 рублей/кг. В целом средняя цена реализации составляла 80 рублей/кг. При получении урожая товарного чеснока 15 тонн, валовой доход от продажи составлял 1 млн. 200 тыс. рублей.

\section{Таблица 1. Структура производственных затрат на 1 га чеснока при однолетнем выращивании из} зубка

\begin{tabular}{|c|c|c|}
\hline Наименование статьи затрат & Сумма, руб. & $\%$ \\
\hline Стоимость посадочного материала & 225000 & 83,9 \\
\hline Оплата аренды земли & 12000 & 3,5 \\
\hline \multicolumn{3}{|c|}{ Подготовка почвы } \\
\hline Вспашка & 1200 & 0,4 \\
\hline Культивация & 600 & 0,2 \\
\hline Предпосевная культивация & 600 & 0,2 \\
\hline Нарезание гряд & 600 & 0,2 \\
\hline Затраты по подготовке почвы: & 3000 & 1,0 \\
\hline \multicolumn{3}{|c|}{ Посадка и уход за растениями } \\
\hline Подготовка посадочного материала & 8000 & 2,3 \\
\hline Посадка & 20000 & 5,8 \\
\hline Междурядная культивация (Зраза) & 1800 & 0,5 \\
\hline Удобрение и СЗР & 36000 & 10,5 \\
\hline Удаление стрелок & 3000 & 0,9 \\
\hline Затраты на посадку и уход за растениями & 293800 & 85,6 \\
\hline \multicolumn{3}{|c|}{ Уборка } \\
\hline Подкапывание (скобой) & 2000 & 0,6 \\
\hline Уборка комбайном в пучки & 1800 & 0,5 \\
\hline Сборка, обрезка и затаривание & 30000 & 8,8 \\
\hline Затраты на уборку: & 33600 & 9,9 \\
\hline Итого: & 342600 & 100 \\
\hline
\end{tabular}

При расчете экономической эффективности производства озимого чеснока кроме производственных затрат были учтены накладные затраты, административные расходы, представительские расходы, канцелярия, услуги связи, амортизация основных средств, содержание и текущий ремонт зданий, сооружений и инвентаря, недостачи и потери от порчи продукции и прочие расходы, не связанные с основным процессом производства. На эти цели выделялось $25 \%$ от суммы производственных затрат, что составляло 85 тысяч 650 рублей. Налог на реализацию сельхозпродукции (10 \%) составлял 120000 рублей. Итого полная себестоимость производства и реализации продукции в среднем за три года составляла: чистая прибыль (доход за вычетом всех производственных, накладных затрат и налогов) - 651750 рублей, рентабельность производства и реализации товарного чеснока - 54,8 \% (табл. 2).

Таблица 2. Экономическая эффективность производства и реализации товарного чеснока, выращенного из зубка в озимой культуре, (среднее за 3 года)

\begin{tabular}{|l|c|}
\hline \multicolumn{1}{|c|}{ Наименование } & Показатели \\
\hline Площадь посева, га & 1 \\
\hline Урожайность, кг/га & 15000 \\
\hline Объем производства, кг & 15000 \\
\hline Цена реализации, руб. & 80 \\
\hline Доход, руб. & 1200000 \\
\hline Полная себестоимость, руб., в том числе: & 548250 \\
\hline - Производственные затраты, руб. & 342600 \\
\hline - Накладные затраты, тыс. руб. & 85650 \\
\hline - Налоги, руб. & 120000 \\
\hline Чистая прибыль, руб. & 651750 \\
\hline Рентабельность, \% & 54,8 \\
\hline
\end{tabular}


В хозяйстве используют двухлетнюю технологию выращивания озимого чеснока из воздушных луковичек без пересадки. Норма посадки воздушных луковичек 25 - 30 кг/га. Цена на закупку посадочного материала от 800 до 1000 рублей за килограмм. Максимальные затраты на гектар 30000 рублей. В первый год все агромероприятия направлены на уход за растениями: рыхление почвы, минеральное питание растений, борьба с сорняками и болезнями. Из воздушных луковичек формируются однозубки, которые оставляют в зиму без пересадки. Они вертикально ориентированы в почве и на следующий год формируют ровную луковицу, обеспечивая максимальный выход товарного чеснока. Основная проблема при двухлетнем выращивании борьба с сорной растительностью. Основные потери урожая при данной технологии происходят в зимний период.

В структуру производственных затрат включена стоимость всех этапов технологии выращивания. Весь технологический процесс рассчитан на 2 года. Затраты на производство в первый год составляли 97 тысяча 200 рублей (50,6 \%), во второй - 92 тысячи 800 рублей (49,4%). Итого производственные затраты на 1 га при данной технологии выращивания составляли 190000 рублей (табл. 3).

Таблица 3. Структура производственных затрат на один гектар при выращивании чеснока из воздушных луковичек без пересадки, (среднее за 3 года).

\begin{tabular}{|l|c|c|}
\hline \multicolumn{1}{|c|}{ Наименование статьи затрат } & Сумма, руб. & \% \\
\hline 1 год & 12000 & 6,3 \\
\hline Оплата аренды земли & 1200 & 0,6 \\
\hline Подготовка почвы & 600 & 0,3 \\
\hline Вспашка & 600 & 0,3 \\
\hline Культивация & 600 & 0,3 \\
\hline Предпосевная культивация & 3000 & 1,5 \\
\hline Нарезание гряд & 10000 & 5,2 \\
\hline Затраты по подготовке почвы: & 20000 & 10,4 \\
\hline Посадка и уход за растениями & 1200 & 0,6 \\
\hline Подготовка к посадке & 10000 & 5,2 \\
\hline Посадка & 56000 & 29,3 \\
\hline Рыхление междурядий (2 раза) & 97200 & 50,6 \\
\hline Прополка (2 раза) & 12000 & 6,3 \\
\hline Питание и СЗР & \multicolumn{2}{|l|}{} \\
\hline Итого 1 год производства: & 56000 & 29,3 \\
\hline 2 год & 1800 & 0,9 \\
\hline Оплата аренды земли & 3000 & 1,5 \\
\hline Уход за растениями и уборка & 2000 & 1,1 \\
\hline Удобрения и СЗР & 30000 & 16,6 \\
\hline Рыхление междурядий (3 раза) & 92800 & 49,4 \\
\hline Удаление стрелок & 190000 & 100 \\
\hline Копка (скобой) & Сборка, обрезка, затаривание & \multicolumn{1}{|c|}{} \\
\hline Итого 2 год производства: & Итого: & \\
\hline
\end{tabular}

При цене реализации товарного чеснока 80 рублей за 1 кг валовой доход составлял 1 млн. 40 тысяч рублей. Производственные затраты за два года выращивания составили 190000 рублей. На административные расходы, представительские расходы, канцелярию, услуги связи, амортизация основных средств, содержание и текущий ремонт зданий, сооружений и инвентаря, недостачи и потери от порчи продукции и прочие расходы, не связанные с основным процессом производства, выделялось $25 \%$ от суммы производственных затрат - 55 тысяч рублей. Налог на реализацию сельхозпродукции
(10 \%) составил 104000 рублей. Чистая прибыль (доход за вычетом всех производственных, накладных затрат и налогов) составляла 661 тысячу рублей, рентабельность производства чеснока - 174,4 \% (табл. 4).

Учитывая, что сегодня производство чеснока в Краснодарском крае и в целом по стране, не может удовлетворить потребности населения и сосредоточенно в основном в приусадебном хозяйстве, а промышленное производство только начинает развиваться, налаживание данного вида хозяйственной деятельности еще долгое время будет приносить 
хороший доход $[4,7,9]$. Но для того чтобы получить максимальный урожай и окупать затраты все техно- логические приемы выращивания чеснока должна быть выполнены качественно и в полном объёме.

Таблица 4. Экономическая эффективность производства чеснока из воздушных луковичек без пересадки, (среднее за 3 года)

\begin{tabular}{|l|c|}
\hline \multicolumn{1}{|c|}{ Наименование } & Показатели \\
\hline Площадь посева, га & 1 \\
\hline Урожайность, кг/га & 13000 \\
\hline Цена реализации, руб./кг & 80 \\
\hline Валовой доход, руб./га & 1040000 \\
\hline Полная себестоимость, руб., в том числе: & 379000 \\
\hline - Производственные затраты, руб. & 190000 \\
\hline - Стоимость посадочного материала, руб. & 30000 \\
\hline - Накладные затраты, тыс. руб. & 55000 \\
\hline Налоги, руб. & 104000 \\
\hline Чистая прибыль, руб. & 661000 \\
\hline Рентабельность, \% & 174,4 \\
\hline
\end{tabular}

Чеснок всегда востребован на потребительском рынке, так как местные производители не могут обеспечить необходимое его количество. Такой бизнес будет вполне реален для любых сельхозпроизводителей. Для выращивания чеснока в озимой культуре нужны начальные капиталовложения, доход будет достаточно велик, чтобы обеспечить рентабельность производства и в дальнейшем развивать этот бизнес [2].

\section{Выводы}

1. В хозяйстве экономическая эффективность при однолетнем выращивании товарного чеснока с использование в качестве посадочного материала зубка составляет - 54,8 \%. При таком способе выращивания производственные затраты на один гектар - 548250 руб./га, большая часть которых приходится на приобретение посадочного материала.

2. При двухлетнем выращивании чеснока экономическая эффективность в 3,2 раза выше, рентабельность производства составляет - 174,4 \%. Использование воздушных луковичек в качестве посадочного материала позволяет значительно снизить производственные затраты и раздробить их на два года. Выход товарной луковицы более 90 \%, тогда как при выращивании из зубка этот показатель не превышает 70 \%. Однако поле занято под культурой в течение двух лет.

\section{ЛИТЕРАТУРА}

1. Боголепова, Н.И. Технология возделывания чеснока / Н.И. Боголепова // Рекомендации. - Краснодар, 2006. $24 \mathrm{c}$.

2. Возделывание чеснока в хозяйствах Краснодарского края / ГБУ КК Кубанский сельскохозяйственный ИКЦ. Краснодар, 2012. - 11 с.

3. Гиш, Р.А. Проблемы научного обеспечения овощеводства Юга России / Р.А. Гиш, А.И. Грушанин, Л.В. Есаулова // Материалы межд.науч.-практ.конф. - Краснодар. - 2006. - 248 с.

4. Гиш, Р.А. Технология выращивания чеснока на выщелоченных черноземах Кубани в условиях малых форм хозяйствования. Меры господдержки субъектов малого предпринимательства в агропромышленном комплексе Краснодарского края / Р.А. Гиш, Е.Н. Благородова, С.Г. Лукомец, А.Е. Горбань //Научно-производственное пособие. Краснодар, 2013. - 44 c.

5. Гиш, Р.А. Эффективные приёмы возделывания плодов и овощей в Краснодарском крае / Р.А. Гиш, Е.Н. Благородова, Б.С. Гегечкори, В.Е. Болахоненков // Сборник Трудов. - Выпуск 399 (427). - Краснодар. 2002. - 160 с.

6. Кубанский сельскохозяйственный информационно-консультативный центр, www.kaicc.ru, дата обращения 18.11.2020.

7. Любченко, А.В. Адаптивность и качество продукции луков (Allium L.) в условиях предгорной зоны Северо-Западного Кавказа / А.В. Любченко, В.А. Семенов. - Майкоп: изд-во Магарин О.Г., 2019. - 160 с.

8. Микаелян, Г.А. Основы оптимального проектирования производственных процессов в овощеводстве / Г.А. Микаелян, Р.Д. Нурметов. - М.: ФГНУ «Росинформагротех», 2005. - 640 с.

9. Мойсевич, Н.В. Производство семян лука репчатого. Биология, агротехника, экономика: монография / Н.В. Мойсевич, А.А. Аутко, Н.П. Купреенко, Г. И. Гануш. - Минск: Типография «ВЮА», 2009. - 144 с.

10. Федеральная служба государственной статистики, https://rosstat.gov.ru/compendium/document/13277, дата обращения 18.11.2020.

11. Ukrainian Garlic Company, https://ukrup.com.ua/ru/ispaniya-obzor-proizvodstva-i-rynka-chesnoka, дата обращения 18.11.2020. 


\section{REFERENCES}

1. Bogolepova, N.I. Garlic cultivation technology / N.I. Bogolepova // Recommendations. - Krasnodar, 2006. - 24 p.

2. Cultivation of garlic in the farms of the Krasnodar Territory / GBU KK Kuban Agricultural ICC. - Krasnodar, 2012. - 11 p.

3. Guiche, R.A. Problems of scientific support of vegetable growing in the South of Russia / R.A. Gish, A.I. Grushanin, L.V. Esaulova // Materials of the international scientific-practical conference. - Krasnodar. - 2006. -248 p.

4. Guiche, R.A. Technology of growing garlic on leached chernozems of the Kuban under conditions of small farming. Measures of state support for small businesses in the agro-industrial complex of the Krasnodar Territory. Gish, E.N. Blagorodova, S.G. Lukomets, A.E. Gorban // Scientific and production manual. - Krasnodar, 2013. - 44 p.

5. Guiche, R.A. Effective methods of cultivation of fruits and vegetables in the Krasnodar Territory / R.A. Gish, E.N. Blagorodova, B.S. Gegechkori, V.E. Bolakhonenkov // Collected Works. - Issue 399 (427). - Krasnodar. 2002. - 160 p.

6. Kuban Agricultural Information and Advisory Center, www.kaicc.ru, 11/18/2020.

7. Lyubchenko, A.V. Adaptability and quality of onions (Allium L.) production in the conditions of the foothill zone of the North-West Caucasus / A.V. Lyubchenko, V.A. Semyonov. - Maikop: publishing house Magarin O.G., 2019. - 160 p.

8. Mikaelyan, G.A. Fundamentals of optimal design of production processes in vegetable growing / G.A. Mikaelyan, R.D. Nurmetov. - M.: FGNU "Rosinformagrotech", 2005. - 640 p.

9. Moisevich, N.V. Production of onion seeds. Biology, agricultural technology, economics: monograph / N.V. Moisevich, A.A. Autko, N.P. Kupreeenko, G.I. Ganush. - Minsk: Printing house "VYUA", 2009. - 144 p.

10. Federal State Statistics Service, https://rosstat.gov.ru/compendium/document/13277, 11/18/2020.

11. Ukrainian Garlic Company, https://ukrup.com.ua/ru/ispaniya-obzor-proizvodstva-i-rynka-chesnoka, 11/18/2020.

\section{Виктор Эдуардович Лазько}

Ведущий научный сотрудник лаборатории бахчевых и луковых культур

E-mail: lazko62@mail.ru

\section{Ольга Владимировна Якимова}

Научный сотрудник лаборатории

бахчевых и луковых культур

E-mail: belyaeva12092013@yandex.ru

Bce: ФГБНУ «ФНЦ риса»

350921, г. Краснодар, пос. Белозерный, 3

Елена Николаевна Благородова

Доцент кафедры овощеводства ФГБОУ КубГАУ имени И.Т. Трубилина

350044, г. Краснодар, ул. Калинина, 13

\section{Victor E. Lazko}

Leading researcher of the laboratory

of melon and onion crops

E-mail: lazko62@mail.ru

\section{Olga V. Yakimova}

Researcher of the laboratory

of melon and onion crops

E-mail: belyaeva12092013@yandex.ru

All: FSBSI "FSC of rice"

3, Belozerny, Krasnodar, 350921, Russia

\section{Elena N. Blagorodova}

Associate professor

FGBOU KubSAU named after I.T. Trubilin 13, Kalinina st., Krasnodar, 350044, Russia 


\section{МЕТОДЫ АНАЛИЗА И МЕХАНИЗМЫ УСТОЙЧИВОСТИ К ЗАСУХЕ (ОбЗОр)}

Изменение климата сделало селекцию на засухоустойчивость одним из основных направлений селекционной работы по большинству культур. В статье представлен обзор механизмов устойчивости к засухе общих для большинства сельскохозяйственных растений, а также описаны методики оценки на засухоустойчивость позволяющие провести экспресс анализ для выявления источников по признаку. Приведена вариабельность признаков при их использовании в зависимости от фазы развития у различных культур. Показано, что засухоустойчивость многих видов растений определяет водный баланс тканей, характеризующийся рядом признаков: влагоудерживающая способность, оводненность тканей, содержание свободной и связанной воды. Большинство культур показывает вариацию признака в зависимости от фазы развития. Следовательно, для изучения оводненности необходимо проведение предварительного исследования для выявления фазы развития с максимальным размахом по признаку, обеспечивающей наибольшую дифференциацию образцов. Повышение оводненности в период налива и созревания плодов показывает необходимость деления сортов на группы по фазе вегетации при оценке признака. Регуляция осмотического давления с помощью низкомолекулярных органических соединений позволяет также повысить засухоустойчивость, их роль у растений выполняют: моно- и олигосахариды, аминокислоты, производные аминокислот - бетаины, многоатомные спирты. Аминокислоты, принимающие участие в защите растений при стрессе: аланин, фенилаланин, $\gamma$-аминомасляная кислота и пролин. Высокое содержание антиоксидантов защищает мембраны от разрушения под действием свободных радикалов, этот механизм защиты характерен для многих видов растений. Характеристика устьиц также может быть диагностическим признаком.

Ключевые слова: рис, адаптивность, засуха, устойчивость к стрессам, методы оценки, механизмы устойчивости.

\section{ANALYSIS METHODS AND MECHANISMS OF RESISTANCE DROUGHT}

Climate change has made selection for drought tolerance one of the main areas of breeding work for most crops. The paper reviews the mechanisms of drought resistance common to most agricultural plants, as well as describes methods for assessing drought resistance, which allow for express analysis to identify sources by trait. The variability of traits when using them, depending on the phase of development in different cultures, is given. It is shown that the drought resistance of many plant species determines the water balance of tissues, which is characterized by a number of features: water-holding capacity, tissue water content, content of free and bound water. Most cultures show variation in trait depending on the phase of development. Consequently, to study the water content, it is necessary to conduct a preliminary study to identify the phase of development with the maximum range according trait, providing the greatest differentiation of samples. An increase in water content during the period of filling and ripening of fruits shows the need to divide varieties into groups according to the growing season when evaluating a trait. The regulation of osmotic pressure with the help of low molecular weight organic compounds also makes it possible to increase drought resistance, their role in plants is played by: mono- and oligosaccharides, amino acids, derivatives, amino acids - betaines, polyhydric alcohols. Amino acids involved in plant protection under stress: alanine, phenylalanine, $\gamma$-aminobutyric acid and proline. The high content of antioxidants protects membranes from destruction by free radicals, this defense mechanism is characteristic of many plant species. Stoma characteristic can also be diagnostic.

Key words: rice, adaptability, drought, resistance to stress, assessment methods, mechanisms of resistance.

\section{Введение}

В связи с изменением климата селекция на засухоустойчивость и устойчивость к высоким температурам становится с каждым годом все более актуальной $[8,15]$. Засуха нарушает ряд физиологических и биохимических процессов, что приводит к ослабле- нию растений и снижению устойчивости и к другим стрессовым факторам [16 - 23]. Морфологически это проявляется в уменьшении площади листьев, высоты растений, количестве продуктивных стеблей. В то же время устойчивые к засухе растения, как правило, более устойчивы к засолению, низким 
температурам, так как при всех этих стрессах отмечено обезвоживание организма $[10,17]$. За годы селекционной работы разработано огромное число методик оценки на засухоустойчивость, но результативность их использования и вариабельность по признаку значительно различаются.

\section{Цель исследований}

Провести анализ механизмов устойчивости к засухе, методик оценки селекционного материала на адаптивность к недостатку воды в период вегетации у различных культур, что позволит более эффективно вести селекцию по признаку.

Водный режим растения. Для многих культур показано, что засухоустойчивость зависит от водного режима растений, основной характеристикой которого является влагоудерживающая способность $[1,12,14]$. У растений сформировался ряд защитно-приспособительных механизмов, предохраняющих их от воздействия стресса. Способность к удержанию воды один из них, позволяющий поддерживать стабильность цитоплазмы клеток, их коллоидность $[18,19]$.

Оводненность тканей другой признак, характеризующий водный баланс растения. Оводненность тканей определяют срезая и взвешивая 10 флаговых листьев образца, насыщяют их водой (для определения водоудерживающей способности), выдерживая в течение 1,5 ч в чашках с водой, повторно взвешивают, высушивают до постоянной массы при температуре $105^{\circ} \mathrm{C}$ и измеряют сухую массу.

Оводненность - разность между сырой и сухой массой выраженная в процентах. Установлено снижение признака в зависимости от возраста растений для многих плодовых культур и злаков. То есть при проведении исследований надо учитывать фазу развития образцов и период вегетации. Вариабельность по признаку у груши в июне месяце была 42,3 - 64,2 \%. Минимальной она была у сорта Вильямс и максимальной у сортов Нарт и Киффер. В июле у этой культуры размах варьирования по признаку был выше: от 21 \% у сорта Кавказ до 79 \% у сорта Вильямс ставропольский. У яблони оводненность листьев варьировала в меньшей степени: от 58 до 68 \% в июне, от 60 до 69 \% в августе и падала от 50 до 58 \% в сентябре. То есть для ряда сортов яблони и груши характерна закономерность - повышение оводненности в период налива и созревания плодов. Несмотря на то, что температуры в этот период как правило максимальны [3 - 5].

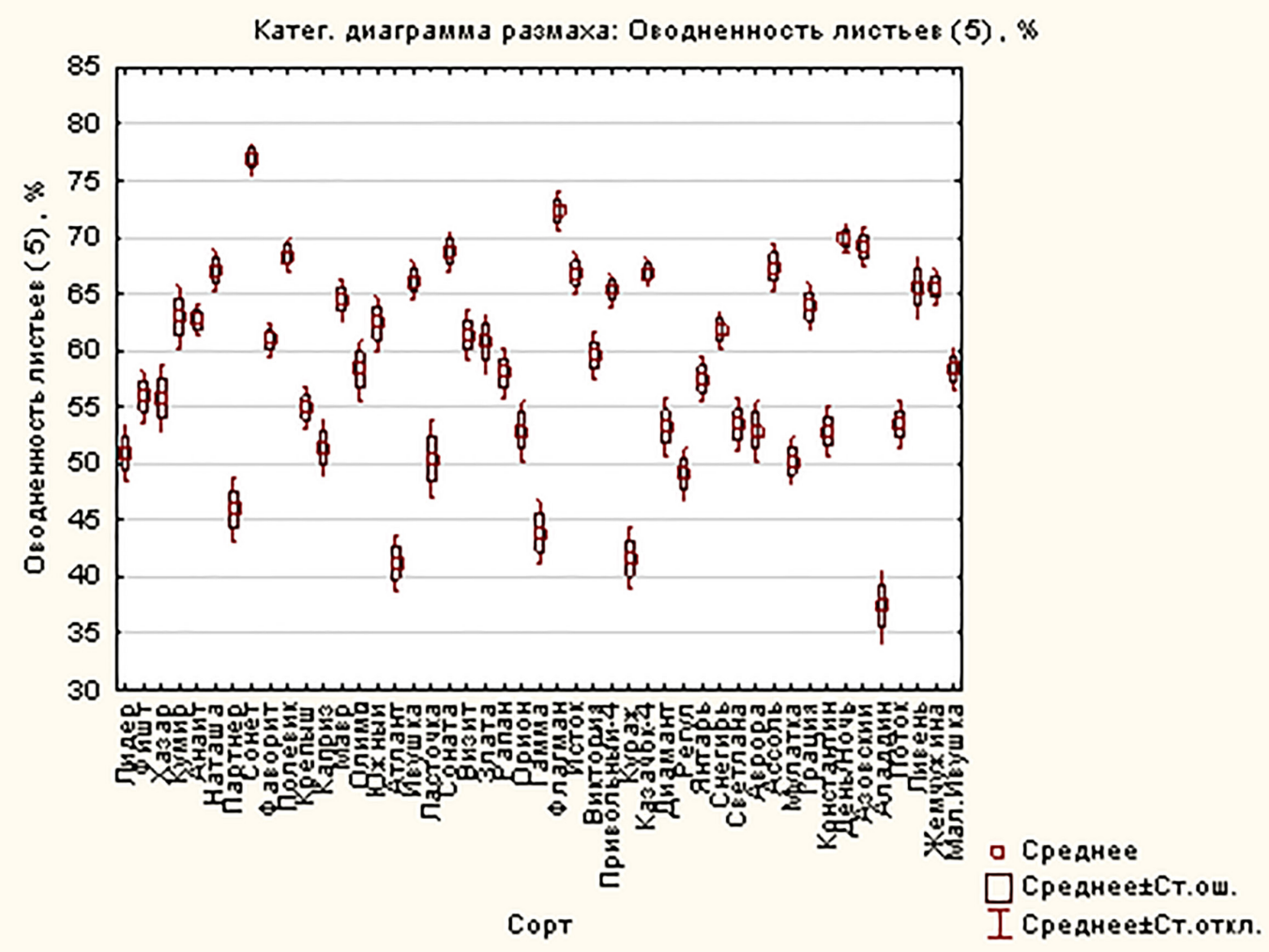

\section{Рисунок 1. Оводненность листьев отечественных сортов риса}

Устойчивость к засухе комплексна по своей природе, так как растение должно противостоять не только обезвоживанию, но и высоким температурам. Отмечено повышение возможности к адаптации при повышении уровня плоидности. Предполагается что особенности анатомо-морфологического строения триплоидных и тетраплоидных форм яблони (более крупные клетки, устьица и листья более широкие, толстые и жесткие) обуславливают большую оводненность тканей и засухоустойчивость. По оводненности 
листьев диплоидные и тетраплоидные виды яблонь достоверно не отличались. Влагоудерживающая способность была выше у полиплоида яблони Союз за счет меньшего изменения количества связанной воды, по общему содержанию связанной и свободной воды сорта различной плоидности достоверно не различались. Для сортов яблонь характерно более высокое содержание связанной воды в июне, чем в августе в период созревания. Так содержание связанной воды в июне варьировало от 20 до 29 \%, свободной - от 71 до 80 \%, в августе эти показатели были соответственно 40 - 88 \% и 22 - 60 \%. Размах варьирования признаков в июне не превышал 10 \%, в августе он достигал 40 \%, следовательно, для изучение оводненности необходимо проведение предварительного исследования для выявления фазы развития с максимальным размахом по признаку, обеспечивающей наибольшую дифференциацию образцов. Интересно изучение признака не только на листьях, но и на проростках, так как именно в эту фазу растения наиболее уязвимы. Оводненность проростков риса при изучении 47 образцов варьировала от 38 до 77 \% (рис. 1). У образцов риса процент связанной воды был ниже от 4,2 \% до 18, 5 \% (рис. 2).

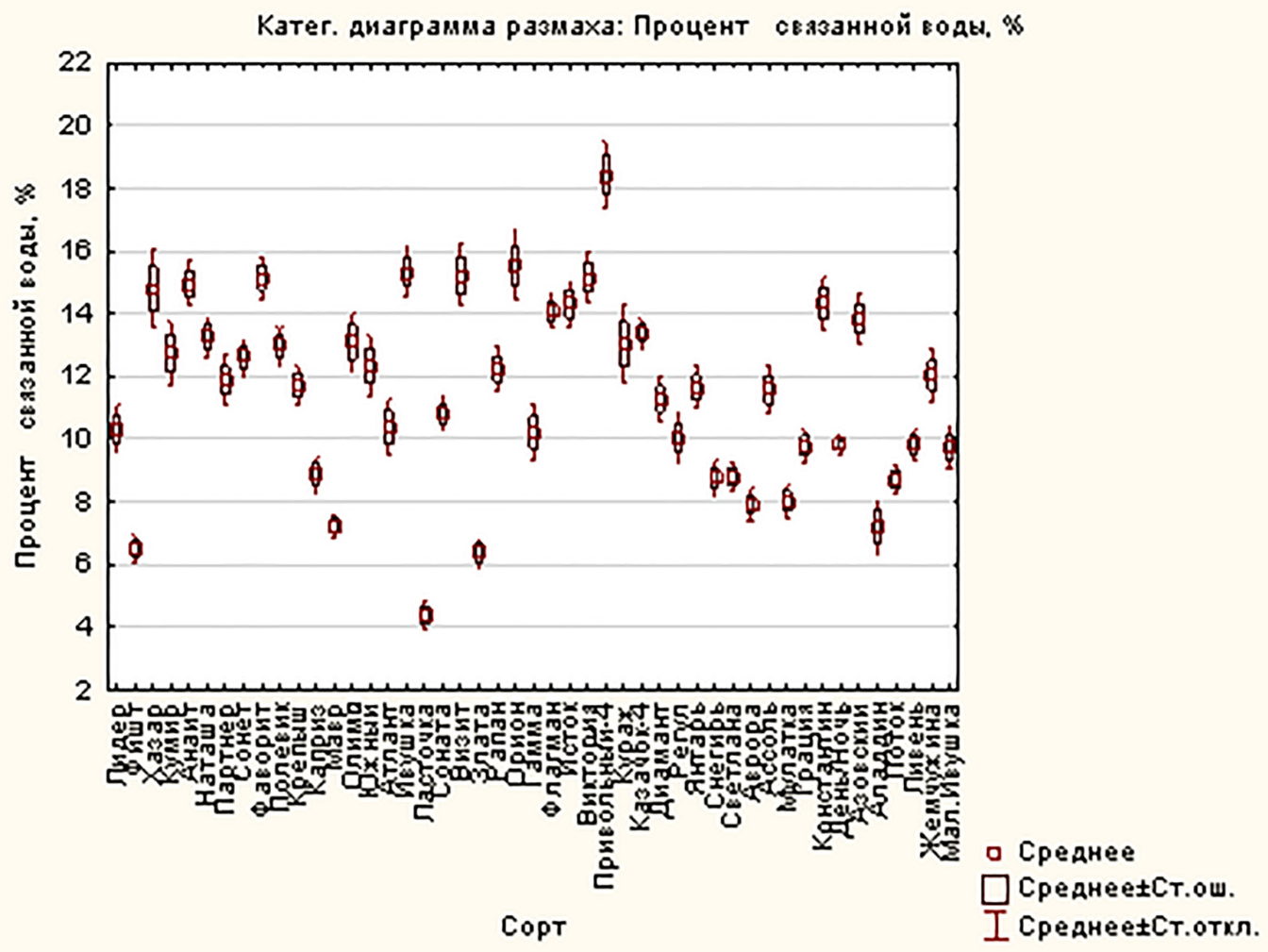

\section{Рисунок 2. Процент связанной воды проростков отечественных сортов риса}

Еще одна характеристика водного режима - потеря воды растениями при завядании. Засухоустойчивые растения способны удерживать и более экономно расходовать воду в условиях ее дефицита. У груши опыт проводили при двух часовом завядании. Отмечена такая же закономерность - варьирование показателя в различные месяцы. Если в июне показатель варьировал от 15 до 46 \%, то в июле потери воды листьями груши превышали у отдельных сортов 55 \%. Признак характеризует водоудерживающую способность образца (рис. 3).

Одна из методик экспресс оценки водного режима - измерение электрического сопротивления тканей листа, увеличение которого при завядании (измерения проводили через три часа после начала опыта) говорит о неустойчивости к стрессу. На основании проведенных исследований для сортов яблони разработан диагностический критерий для оценки засухоустойчивости (ДКЗ) по измерению электрического сопротивления тканей листа. Согласно разработанной шкале засухоустойчивость высокая, если ДКЗ меньше 225 кОм, средняя - если он варьирует от 225 до 250 кОм, низкая - при его значениях менее 250 кОМ. Большая часть тетраплоидных образцов в результате исследования отнесена к высокоустойчивым, диплоидных - к менее устойчивым.

Регуляция осмотического давления. Одним из механизмов приспособления растений к засухе является регуляция осмотического давления с помощью низкомолекулярных органических соединений (осмолитиков). Роль веществ регулирующих осмотическое давление, играют моно- и олигосахариды, аминокислоты, производные, аминокислот - бетаины, многоатомные спирты. Свободные аминокислоты 
наиболее известные осмопротекторы. К настоящему времени накопилось много экспериментальных фактов, свидетельствующих об их защитных свойствах.

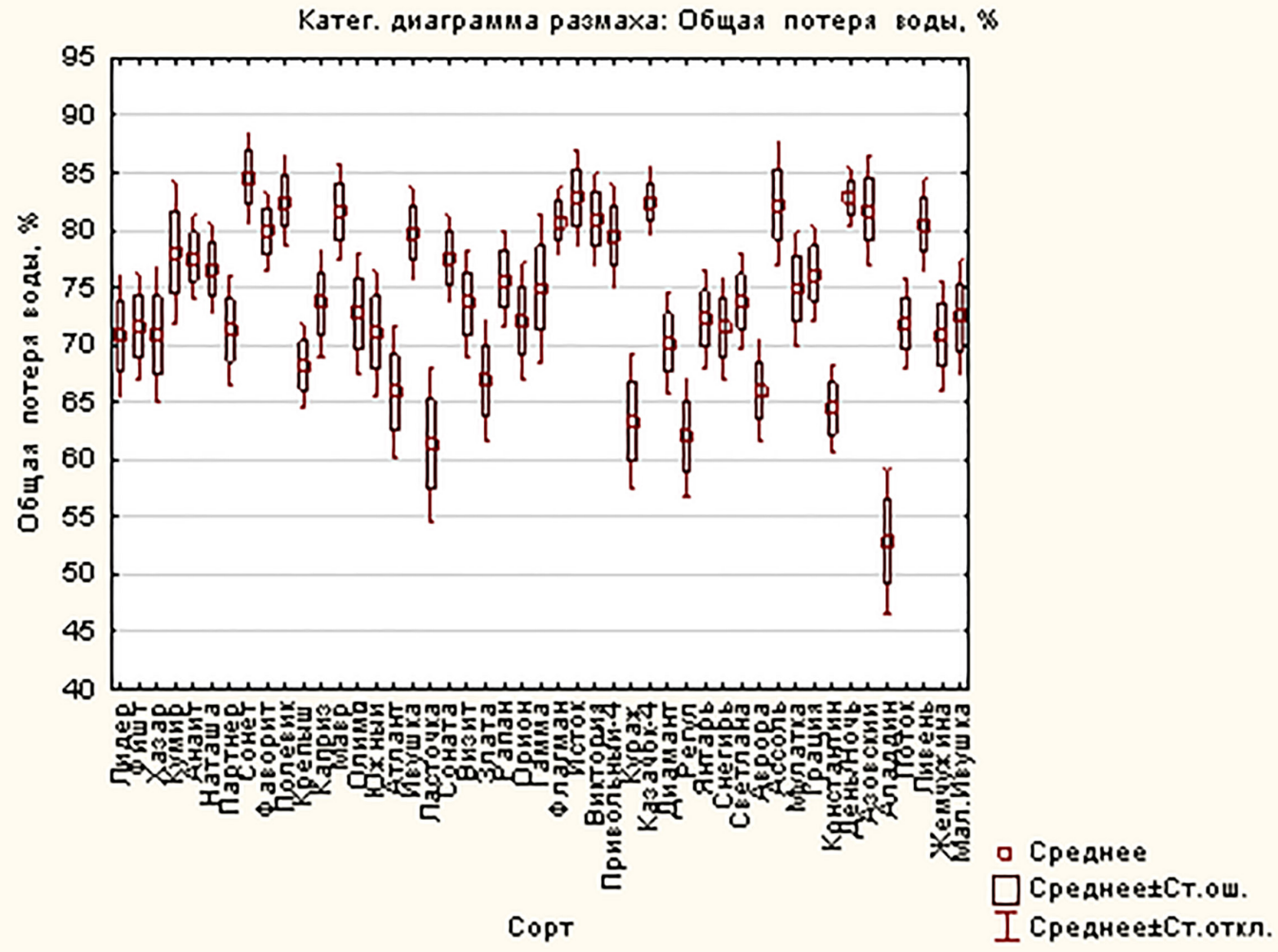

\section{Рисунок 3. Потеря воды проростками отечественных сортов риса, \%}

Выделена группа аминокислот, принимающих участие в защите растений от стрессов. Среди них: аланин, фенилаланин, $\gamma$-аминомасляная кислота и пролин. Участие пролина в ответе растения на воздействие как солевого стресса, так и засухи и низких температур показано во многих работах $[2,7,9]$. Защитное действие пролина связано с его функциями: регулятора экспрессии генов, протектора макромолекул и мембран, регулятора окислительно-восстановительного потенциала, источника энергии, осморегулятора и предшественника осмолитов. Увеличение его содержания при засухе связано с распадом хлорофилла, белков, накоплением абсцизовой кислоты АБК. Отмечено что его предшественником может быть глутамин. Накопление осмотически активных веществ обеспечивает высокую водоудерживающую способность цитоплазмы. Благодаря осмотической регуляции у растений при засухе сохраняются тургор и открытость устьиц следовательно, возможность нормального роста и поддержание других физиологических процессов $[13,19,21]$.

У яблонь сортов Василиса, Флорина, Талида увеличенное содержание пролина повышало засухоустойчивость. Варьирование по признаку у восьми сортов яблонь в июне было выше, чем в августе и составляло от 3 до 100 и от 10 - 70 мг/кг. У злаков подобные результаты получены на пшенице и рисе. Содержание пролина при изучении 39 образцов риса варьировало от 4,8 до 37 \% общего содержания аминокислот. Максимальное количество этой аминокислоты (от 32,5 до 37,3 \%) отмечено у сортов: Березка, Азовский, Атлант, Есаул, Константин. Большинство сортов выделенных как источники по признаку у риса позднеспелые образцы.

Действие антиоксидантных систем. Высокое содержание аскорбиновой кислоты и других антиоксидантов защищает мембраны от разрушения под действием свободных радикалов, этот механизм защиты характерен для сортов яблонь Флорина, Талида. Также защищают от повреждения клеточные мембраны фенол карбоновые кислоты. Оценка уровня абсцизовой кислоты (АБК) в растениях является другим перспективным подходом. Накопление АБК при стрессе ведет к уменьшению клеток, количества устьиц на листе, их закрытию, увеличению опушения листьев, стимулирует синтез осмопротекторов и работу антиоксидантной системы растения и в результате к снижению реагирования организма на водный дефицит $[6,11,20]$. Однако необходимо учитывать, что интенсивность засухи определяет механизм устойчивости растений. При незначительной засухе повышается способность более эффективно поглощать воду. Более продолжительная засуха 
включает механизмы устойчивости, контролируемые абсцизовой кислотой: экономия воды за счет закрытия устьиц, детоксикация организма. У изученных девяти сортов яблони при стрессе повышалось как содержание фенолкарбоновых кислот, так и активность пероксидазы, которая также входит в состав антиоксидантного комплекса растений.

Нами была проведена оценка комплексной активности фенолокисляющих пероксидаз по реакции окисления гваякола белковым экстрактом из проростков риса. Данный вид пероксидаз по результатам исследования является ключевым антиоксидантным ферментом у проростков риса на представленной стадии развития. Медиана составила 8,63 е.а./г белка. Максимальная активность фермента была установлена у сортообразцов с окрашенным перикарпом День/Ночь, Мулатка и Мавр.

Характеристика устьиц. Как уже отмечали, устойчивые к засухе образцы часто имеют ткани с мелкими клетками, это способствует лучшей адаптации к сжатию клеток, возникающему при обезвоживании. При дефиците воды происходит уменьшение числа устьиц на единицу площади. Засуха приводит к ухудшению процесса растяжения клеток и преждевременному старению, изменению вегетативной массы, нарушению процессов фотосинтеза и дыхания. Устьица при засухе закрываются или уменьшается ширина их раскрытия [22].

Надо учитывать, что повышенная оводненность листьев связана с засухоустойчивостью образца, если это не сопровождается снижением площади открытия устьичной щели. Для засухоустойчивых образцов характерна способность терять часть воды, не снижая метаболизма и длительное время не закрывать устьица и продолжать фотосинтез даже во время стресса. У таких образцов большее число устьиц на единицу площади листа, сильно развитые корневая и проводящая системы. Отбор образцов для оценки размера устьиц проводят в фазу цветения отбирая по 10 флаговых листьев, листья фиксируют
96 \%-м спиртом. Измерения проводят на средней части листа длиной один сантиметр, подсчитывают устьица в 4 полях зрения. Площадь устьичной щели вычисляют у двадцати устьиц. У образцов пшеницы количество устьиц на единицу площади варьировало от 3,6 до 13, 2 шт / мм² [23]. У отечественных сортов риса вариабельность меньше, но сорта также достоверно различались по признаку, однако методика их оценки достаточно трудоемка и требует фиксации материала. Для ускорения работы предложено проводить подсчет количества устьиц на единицу длины параллельной жилки не фиксированного материала, учитывая размер устьиц, что быстро позволяет оценить большой обьем образцов, разделить их на группы по ксероморности и в дальнейшем, более детально оценивать только группу источников по признаку (рис. 4).

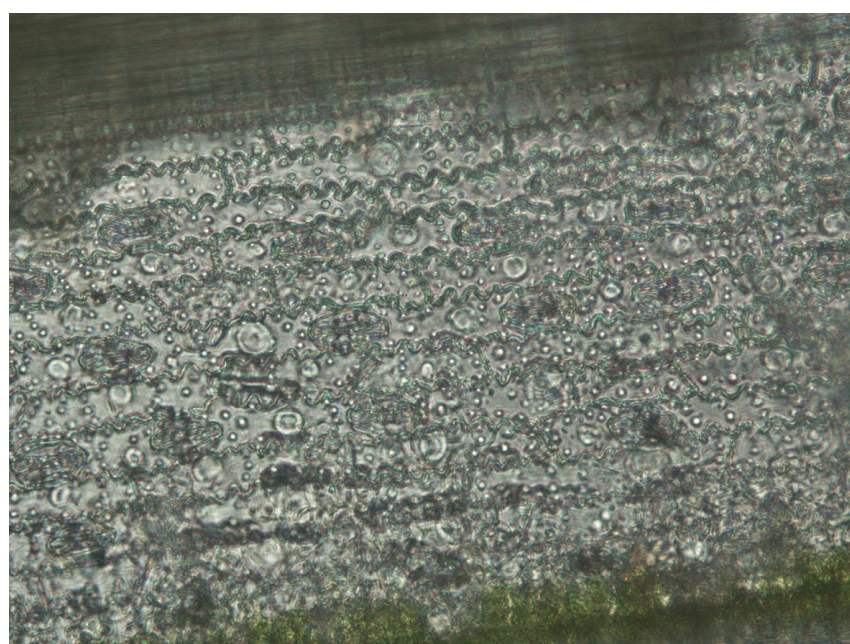

Рисунок 4 . Оценка количества устиц у образца риса Сонет

*Работа выполнена при финансовой поддержке РНФ № 19-16-00064.

\section{ЛИТЕРАТУРА}

1. Боме, H.A. Изучение зависимости водоудерживающей способности листьев Triticum Aestivum L. от их линейных размеров и площади / Н.А. Боме, Т.Ф. Ушакова, Е.А. Моденова и др. // Международный научно исследовательский журнал. - 2016. - № 4(46). - Ч. 6. - С. 13 - 16.

2. Боталова, К.И. Стратегии выживания растений в зоне воздействия солеотвалов г. Соликамска/ К.И. Боталова, О.3. Еремченко, И.Е. Шестаков // Современные проблемы науки и образования. - 2015. - № 3. URL: http://www.science-education.ru/ru/article/view?id=19780 (дата обращения: 31.07.2020).

3. Киселева, Г.К. Формирование адаптационной устойчивости к летней засухе сортов яблони различной плоидности. / Г.К. Киселева, Н.И. Ненько, Е.В. Ульяновская // В книге: Фундаментальные и прикладные аспекты современных эколого-биологических и медико-технологических исследований. Коллективная монография: в 3-х томах. Сер. "Золотая монографическая серия", Нижний Новгород.- 128 с.

4. Можар, Н.В. Поиск засухоустойчивых сортов груши для условий центральной зоны Краснодарского края / Н.В. Можар // Научные Труды Северо-Кавказского федерального научного центра садоводства, виноградарства, виноделия. - 2014. - № 5. - С. $39-42$.

5. Ненько, Н.И. Физиолого-биохимические критерии устойчивости яблони к абиотическим стрессам летнего периода. / Н.И. Ненько, Г.К. Киселева, Е.В. Ульяновская, Е.К. Яблонская, А.В. Караваева // Сельскохозяйственная биология. - 2019. - № 1(54). - С. 158 - 168

6. Ненько, Н.И. Устойчивость сортов винограда различного эколого-географического происхождения к повышенным температурам и засухе / Н.И. Ненько, Г.К. Киселева, А.Е. Мишко, Т.В. Схаляхо, С.В. Федорович, В.В. Вял- 
ков // Научные Труды Северо-Кавказского федерального научного центра садоводства, виноградарства, виноделия. - 2020.- № 28. - С. 105 - 111.

7. Симкина, С.Ю. Состав свободных аминокислот зимующих и набухших меристем почек Pinus sylvestris L. / С.Ю. Симкина, Е.В. Алаудинова // Актуальные проблемы лесного комплекса. - 2009. - № 23. - С. 134 - 136.

8. Терлецкая, H.B. Изучение устойчивости фотосинтетического аппарата мягкой пшеницы (T.aestivum L.) и ee диких сородичей к абиотическим стрессорам in vivo и in vitro. / Н.В. Терлецкая, Н.В. Зобова, В.Ю. Ступко и др. - Алматы: ИП Волкова Е. В., 2017. - С. $56-80$.

9. Харитонов, Е.М. Молекулярное маркирование локусов, определяющих высокие темпы роста на начальных этапах развития растений у российских сортов риса (Oryza sativa L.). / Е.М. Харитонов, Ю.К. Гончарова, С.В. Гончаров, В.Н. Бруяко // Сельскохозяйственная биология. - 2019. - № 5 (54). - С. 892-904.

10. Харитонов, Е. М. О генетико-физиологических механизмах солеустойчивости у риса ( Oryza sativa L.) (Oбзор) / Е.М. Харитонов, Ю.К. Гончарова // Сельскохозяйственная биология. - 2013. - № 3 (48). - С. 3-11.

11. Alabushev, A.V. Estimation of Drought Resistance of Winter Common Wheat under Conditions of Model Drought. / A.V. Alabushev, E.V. Ionova, V.A. Likhovidova, V.L. Gaze // Zemledelije - 2019. - № 7. - P. 35 - 37 (in Russ.).

12. Batlang, U. Phenotypic and Physiological Evaluation for Drought and Salinity Stress Responses in Rice. / U. Batlang, N. Baisakh, M. Ambavaram, A. Pereira, // In Rice Protocols. Methods in Molecular Biology (Methods and Protocols), - 2013. P. $209-225$.

13. Dixit, S. Increased drought tolerance and wider adaptability of qDTY 12.1 conferred by its interaction with qDTY 2.3 and qDTY 3.2. / S.Dixit, B.P.M. Swamy, P. Vikram, J. Bernier, M.T. Cruz, M. Amante,D. Atri, A. Kumar // Mol. Breed. - 2012. 30. - P. 1767 - 1779. doi:10.1007/s11032-012-9760.

14. Goncharova, J.K. Rice Tolerance to the Impact of High Temperatures / J.K. Goncharova, E.M. Kharitonov // Agricultural Research Updates, 2015. - № 9. - P. 1-37.

15. Goncharova, J.K. Localization of chromosome regions controlling high photosynthetic potential in Russian rice cultivars / J.K. Goncharova, S.V. Gontcharov, E.E. Chicharova // Russian Journal of Genetics. - 2018. - № 7(54). P. $796-804$.

16. Jagadish, S.V. Physiological and Proteomic Approaches to Address Heat Tolerance during Anthesis in Rice (Oryza sativa L.)./ S. Muthurajan, R.Oane, R. Wheeler, S. Heuer, J. Bennett, P. Craufurd // J. Exp. Bot. - 2010. - № 61. P. $143-156$.

17. Kharitonov, E.M. The genetics of the traits determining adaptability to abiotic stress in rice (Oryza sativa L.) / E.M. Kharitonov, Y.K. Goncharova, E.A. Maliuchenko // Russian Journal of Genetics: Applied Research. - 2017. - № 6(7). P. $684-697$.

18. Kumar, A. Breeding High-Yielding Drought Tolerant Rice: Genetic Variations and Conventional and Molecular Approaches./ A. Kumar, S. Dixit, T. Ram, R. Yadaw, K. Mishra, N. Mandal // J. Exp. Bot. - 2014. - № 65. - P. 6265 - 6278.

19. Kumar, S. Plant Responses to Drought Stress: Physiological, Biochemical and Molecular Basis. / S. Kumar, S. Sachdeva, K. Bhat, S. Vats // In Biotic and abiotic Stress tolerance in plants, Springer Nature - Singapore. - 2018. - P. 1 - 25.

20. Qin, F. Achievements and challenges in understanding plant abiotic stress responses and tolerance / F. Qin, K. Shinozaki, K. Yamaguchi-Shinozaki// Plant Cell Physiol. - 2011 - № 52. - P.1569 - 1582.

21. Sandhu, N. Bridging the Rice Yield Gaps under Drought: QTLs, Genes, and Their Use in Breeding Programs / N. Sandhu, A. Kumar // Agron. J. - 2017 - № 7. - P. 27.

22. Sandhu, N. Genetic Variation, Linkage Mapping of QTL and Correlation Studies for Yield, Root, and Agronomic Traits for Aerobic Adaptation. / N. Sandhu, S. Jain, A. Kumar, B. Mehla, R. Jain // BMC Genet, - 2013. - № 14. - P.104. DOI:10.1186/1471-2156-14-104.

23. Swain, $P$. Characterization of some Indian native land race rice accessions for drought tolerance at seedling stage / M. Anumalla, S. Prusty, B. Marndi , G. Rao // Aust. J. Crop Sci. - 2014. - № 8. - P. 324 - 331.

\section{REFERENCES}

1. Bohme, N.A. Study of the dependence of the water-holding capacity of Triticum Aestivum L. leaves on their linear size and area / N.A. Bohme, T.F. Ushakova, E.A. Modenova, et al. // International scientific research journal - 2016. - № 4(46). Ch. 6. - P. 13 - 16.

2. Botalova, K.I. Strategies of plant survival in the zone of influence of salt dumps in Solikamsk / K.I. Botalova, O.Z. Eremchenko, I.E. Shestakov // Modern problems of science and education. - 2015. - № 3. URL: http://www.science-education. ru/ru/article/view?id=19780 (date of access: 07/31/2020).

3. Kiseleva, G.K. Formation of adaptive resistance to summer drought of apple varieties of different ploidy. / G.K. Kiseleva, N.I. Nenko, E.V. Ulyanovskaya // In the book: Fundamental and applied aspects of modern ecological-biological and medical-technological research. Collective monograph: in 3 volumes. Ser. "Golden Monographic Series", Nizhny Novgorod. $128 \mathrm{p}$.

4. Mozhar, N.V. Search for drought-resistant varieties of pears for the conditions of the central zone of the Krasnodar Territory / N.V. Mozhar // Scientific Works of the North Caucasian Federal Scientific Center for Horticulture, Viticulture, Winemaking. - 2014. - № 5. - P. 39 - 42.

5. Nenko, N.I. Physiological and biochemical criteria of apple tree resistance to abiotic stresses of the summer period. / N.I. Nenko, G.K. Kiseleva, E.V. Ulyanovskaya, E.K. Yablonskaya, A.V. Karavaeva // Agricultural biology. - 2019. - № 1(54). P. 158 - 168. 
6. Nenko N.I. Resistance of grape varieties of different ecological and geographical origin to high temperatures and drought / N.I. Nenko, G.K. Kiseleva, A.E. Mishko, T.V. Shalyakho, S.V. Fedorovich, V.V. Vyalkov // Scientific Works of the North Caucasian Federal Scientific Center of Horticulture, Viticulture, Winemaking. - 2020. - № 28. - P. $105-111$.

7. Simkina, S.Yu. Composition of free amino acids of wintering and swollen bud meristems of Pinus sylvestris L. / S.Yu. Simkina, E.V. Alaudinova // Actual problems of the forestry complex. - 2009. - № 23. - P. 134 - 136.

8. Terletskaya, N.V. Study of the resistance of the photosynthetic apparatus of common wheat (T. aestivum L.) and its wild relatives to abiotic stressors in vivo and in vitro. / N.V. Terletskaya, N.V. Zobova, V.Yu. Stupko and others - Almaty: IP Volkova E.V. - 2017. - P. 56-80.

9. Kharitonov, E.M. Molecular marking of loci that determine high growth rates at the initial stages of plant development in Russian rice varieties (Oryza sativa L.). / E.M. Kharitonov, Yu.K. Goncharova, S.V. Goncharov, V.N. Bruyako // Agricultural biology. - 2019. - № 5(54). - P. 892 - 904.

10. Kharitonov, E.M. On the genetic and physiological mechanisms of salt tolerance in rice (Oryza sativa L.) (Review) / E.M. Kharitonov, Yu.K. Goncharova // Agricultural biology. - 2013. - № 3(48). - P. 3 - 11.

11. Alabushev, A. Estimation of Drought Resistance of Winter Common Wheat under Conditions of Model Drought / A.V. Alabushev, E.V. Ionova, V.A. Likhovidova, V.L. Gaze // Zemledelije - 2019. - № 7. - P. 35 - 37 (in Russ.).

12. Batlang, U. Phenotypic and Physiological Evaluation for Drought and Salinity Stress Responses in Rice. / U. Batlang, N. Baisakh, M. Ambavaram, A. Pereira, // In Rice Protocols. Methods in Molecular Biology (Methods and Protocols). - 2013. P. $209-225$.

13. Dixit, S. Increased drought tolerance and wider adaptability of qDTY 12.1 conferred by its interaction with qDTY 2.3 and qDTY 3.2. / S.Dixit, B.P.M. Swamy, P. Vikram, J. Bernier, M.T. Cruz, M. Amante,D. Atri, A. Kumar // Mol. Breed. - 2012. 30. - P. 1767 - 1779. doi:10.1007/s11032-012-9760.

14. Goncharova, J.K. Rice Tolerance to the Impact of High Temperatures / J.K. Goncharova, E.M. Kharitonov // Agricultural Research Updates. - 2015. - № 9. - P. 1 - 37.

15. Goncharova, J.K. Localization of chromosome regions controlling high photosynthetic potential in Russian rice cultivars / J.K. Goncharova, S.V. Gontcharov, E.E. Chicharova // Russian Journal of Genetics. - 2018. - № 7(54). - P. 796 - 804.

16. Jagadish, S.V. Physiological and Proteomic Approaches to Address Heat Tolerance during Anthesis in Rice (Oryza sativa L.)./ S. Muthurajan, R.Oane, R. Wheeler, S. Heuer, J. Bennett, P. Craufurd // J. Exp. Bot. - 2010. - № 61. - P. 143 - 156.

17. Kharitonov, E.M. The genetics of the traits determining adaptability to abiotic stress in rice (Oryza sativa L.) / E.M. Kharitonov, Y.K. Goncharova, E.A. Maliuchenko // Russian Journal of Genetics: Applied Research. - 2017. - № 6(7). - P. 684 - 697.

18. Kumar, A. Breeding High-Yielding Drought Tolerant Rice: Genetic Variations and Conventional and Molecular Approaches / A. Kumar, S. Dixit, T. Ram, R. Yadaw, K. Mishra, N. Mandal // J. Exp. Bot. - 2014. - № 65. - P. 6265 - 6278.

19. Kumar, S. Plant Responses to Drought Stress: Physiological, Biochemical and Molecular Basis. / S. Kumar, S. Sachdeva, K. Bhat, S. Vats // In Biotic and abiotic Stress tolerance in plants, Springer Nature - Singapore. - 2018. - P. 1 - 25.

20. Qin, F. Achievements and challenges in understanding plant abiotic stress responses and tolerance./ F. Qin, K. Shinozaki, K. Yamaguchi-Shinozaki // Plant Cell Physiol. - 2011. - № 52. - P. 1569 - 1582.

21. Sandhu, N. Bridging the Rice Yield Gaps under Drought: QTLs, Genes, and Their Use in Breeding Programs / N. Sandhu, A. Kumar // Agron. J. - 2017. - № 7. - P. 27.

22. Sandhu, N. Genetic Variation, Linkage Mapping of QTL and Correlation Studies for Yield, Root, and Agronomic Traits for Aerobic Adaptation. / N.Sandhu, S.Jain, A. Kumar, B. Mehla, R. Jain // BMC Genet. - 2013. - № 14. - P. 104. DOI:10.1186/1471-2156-14-104.

23. Swain, P. Characterization of some Indian native land race rice accessions for drought tolerance at seedling stage / M. Anumalla, S. Prusty, B. Marndi, G. Rao // Aust. J. Crop Sci. - 2014. - № 8. - P. 324 - 331.

\section{Юлия Константиновна Гончарова \\ Заведующая лабораторией генетики и гетерозисной селекции \\ E-mail: yuliya_goncharova_20@mail.ru}

\section{Евгений Михайлович Харитонов}

Научный руководитель института

E-mail: evgeniyharitonov46@mail.ru

\section{Николай Александрович Очкас \\ Ведущий научный сотрудник лаборатории \\ сортовой агротехники \\ и паспортизации сортов риса \\ E-mail: ochkasnikolay@mail.ru}

Bce: ФГБНУ «ФНЦ риса»

350921 Россия, г. Краснодар, пос. Белозерный, 3

\begin{abstract}
Julia Konstantinovna Goncharova
Head of the Laboratory of Genetics and Heterosis Selection

E-mail: yuliya_goncharova_20@mail.ru
\end{abstract}

Evgeny Mikhailovich Kharitonov

Scientific director of the institute

E-mail: evgeniyharitonov46@mail.ru

\section{Nikolay Alekcandrovich Ochkas}

Leading researcher of the laboratory

of varietal agricultural technology

and certification of rice varieties

E-mail: ochkasnikolay@mail.ru

All: FSBSI "FSC of rice"

3, Belozerny, Krasnodar, 350921, Russia 


\section{Сергей Владимирович Гончаров}

Профессор кафедры селекции, семеноводства

и биотехнологии

E-mail: slogan1960@mail.ru

ФГБОУ ВО «Воронежский ГАУ

им. Императора Петра |»

394087 Россия, г. Воронеж, ул. Мичурина 1

\section{Сергей Викторович Свинарёв}

Преподаватель кафедры специальных дисциплин

E-mail: squire@inbox.ru

Волгодонский филиал Ростовского юридического института МВД РФ

ВФ ФГКОУ ВО РЮИ МВД России

347360, Ростовская область, г. Волгодонск,

ул. Степная, 40

\section{Sergey Vladimirovich Goncharov}

Full Professor of Crop Breeding \& Biotechnology

Chair

E-mail: slogan1960@mail.ru

FBGU VO "Voronezh State Agrarian University named after Emperor Peter"

1 Michurin Str., Voronezh, 394087, Russia

\section{Sergey Viktorovich Svinaryev}

Teacher of the Department of Special Disciplines, E-mail: squire@inbox.ru

Volgodonsk branch of the Rostov Law Institute of Ministry of Internal Affairs of the Russian Federation (Volgodonsk, Russia)

VF FGKOU VO RUI Ministry of Internal Affairs of Russia 40, st. Stepnaya, Volgodonsk, Rostov region, 347360, Russia 


\section{ПОЛУЧЕНИЕ ЭКОЛОГО-ГЕОГРФИЧЕСКИ ОТДАЛЕННЫХ ВНУТРИВИДОВЫХ ГИБРИДОВ ХЛОПЧАТНИКА И НАСЛЕДОВАНИЕ ЕГО ХОЗЯЙСТВЕННО-ЦЕННЫХ ПРИЗНАКОВ}

В статье приведены результаты изучения наследования основных характеристик продуктивности гибридов в селекционном питомнике. Как известно, при проведении селекционных экспериментов одним из важнейших моментов является правильный подбор исходных родительских пар. Родительские формы для скрещивания отбираются по эколого-географическому принципу, по совокупности хозяйственно-биологических принципов, по длительности отдельных фаз вегетации, по различиям в устойчивости к болезням и вредителям, по результатам оценки комбинационной способности форм. При отборе отдают предпочтение сортам с наименьшим количеством отрицательных признаков, которые могут быть унаследованы гибридами. Максимальная величина по популяциям гибридов изменяется в диапазоне 98,4 - 118,9 г. Из них самым высоким показателем урожая хлопка-сырца отличались гибриды: Cocer-4104 х Сорбон (118,9 г/растение), ALC-86/6 х Дехкон (116,4 г/растение), DPL-4158 х Дехкон (114,4 г/растение). Самая низкая урожайность наблюдалась у гибридных комбинаций - AC-4 х Сорбон (80,8 г/растение), DP-5111 х Сорбон (88, 1 г/растение). Полученная урожайность гибридов оказалась на 51,8 - 63, 1 г/растение. Таким образом, по данным исследований, из всех (16) комбинаций наиболее доминирующими признаками отличались следующие образцы: AC-4 х Зироаткор-64, Cocer-4104 х Сорбон, Cocer-4104 х Дусти-ИЗ и CUZ-F3 х Дехкон. Коэффициенты наследования скороспелости, крупноплодности и высокой урожайности для этих гибридов составили $62 \% ; 86$ \% и $85 \%$.

Ключевые слова: хлопчатник, сорт, родительских формы наследование, раннеспелость, масса сырца одной коробочек, урожайность.

\section{RECEIVED ECOLOGO-GEOGRAPHICALLY REMOTE INTRASPECIFIC HYBRIDS OF COTTON AND THEIR INHERITANCE OF ECONOMICALLY VALUABLE PARAMETERS}

This article presents the results of studying the inheritance of the main characteristics of productivity of hybrids in a breeding nursery. As you know, when conducting breeding experiments, one of the most important points is the correct selection of the original parent pairs. Parent forms for crossing are selected according to the ecological and geographical principle, the totality of economic and biological principles, the duration of individual phases of vegetation, differences in resistance to diseases and pests, and the results of evaluating the combinational ability of forms. When selecting, preference is given to varieties with the least number of negative traits that can be inherited by hybrids. The maximum value for the populations of hybrids varies in the range $98.4-118.9 \mathrm{~g}$. Of these, the hybrids with the highest yield of raw cotton were distinguished: Cocer-4104 x Sorbon (118.9 g/plant), ALC-86/6 $x$ Dehkon (116.4 g/plant), DPL-4158 x Dehkon (114.4 g/plant). The lowest yield was observed in hybrid combinations - AC-4 x Sorbon (80.8 g/plant), DP-5111 x Sorbon (88.1 g/plant). The resulting yield of the hybrids was $51.8-63.1$ $\mathrm{g} /$ plant. Thus, according to research data, the following samples were the most dominant of all (16) combinations: AC-4 x Ziroatkor-64, Cocer-4104 x Sorbon, Cocer-4104 x Dusti-IZ, and CUZ-F3 x Dehkon. The inheritance coefficients of precocity, large-fruiting and high yield for these hybrids were $62 \%$; $86 \%$ and $85 \%$.

Key words: cotton, variety, parental forms of inheritance, early maturation, mass of raw material of one box, yield.

\section{Введение}

В мире существует целый ряд растений, возделываемых человеком ради получения полотна. Эти растения называют волокнистыми или прядильными и являются представителями различных растительных семейств - Мальвовых, Льновых, Липовых и др. По характеру основного продукта их разделяют на плодоволокнистые, стеблеволокнистые, листоволокнистые. Это однолетние и многолетние растения, возделываемые в основном в районах жаркого климата [9].

Главное место среди прядильных культур занимает хлопчатник, дающий 75 \% мирового производства растительного текстильного сырья.
Для интенсификации хлопководства многие страны становятся сейчас на путь улучшения агротехники возделывания, обеспечения органо-минеральными удобрениями, создания и внедрения в производство новых высокопродуктивных сортов интенсивного типа. Характерной особенностью вклада селекции в интенсификацию хлопководства является то, что она позволяет без дополнительных затрат труда и средств повысить урожайность и качество продукции.

Успех синтетической селекции в значительной степени определяется правильным подбором исходных родительских пар (форм) для скрещивания. Если не будут подобраны соответствующие родительские 
формы, гены, которых должны быть рекомбинированы в гибридном организме и в новом сорте, несмотря на разработанную и созданную модель идеального типа и желательного сорта, значительного успеха в селекции достигнуть невозможно Н.И. Вавилов [1].

Родительские формы для скрещивания подбирают на основе эколого-географического принципа, по комплексу хозяйственно-биологических признаков, по продолжительности отдельных фаз вегетации, на основе различий устойчивости к болезням, вредителям, по результатам оценки комбинационной способности форм.

Обычно в селекционно-генетических исследованиях большое внимание уделяется степени наследования соответствующего количественного признака. Степень наследования признака можно оценить по коэффициенту доминирования (hp). По значению коэффициента доминирования также можно установить степень проявления гетерозисного эффекта гибридов по изучаемому признаку [4].

Скороспелость - это структурно-сложный признак и определяется он рядом элементов: продолжительностью вегетативной фазы (всходы-бутонизация), продолжительностью периодов, необходимых для превращения бутона в цветок и однодневной завязи в раскрытую коробочку. Критериями этих межфазных периодов является дата начала и 50 \% бутонизации, цветения и созревания. Морфологическим показателем скороспелости, коррелирующим с датой бутонизации, является высота закладки первой симподиальной ветви (hs). Важным показателем скороспелости являются темпы накопления бутонов, цветов и раскрытия коробочек $[4,6]$.

Для Гиссарской долины скороспелые сорта имеют важное значение, и селекционеры при выведении сортов наряду с урожайностью обращают особое внимание на этот признак. Изменчивость показателей скороспелости в различных условиях выращивания неодинакова [8].

Высоты закладки первого симподия или продолжительность периода от бутонизации до цветения относительно мало подвержена паратипической изменчивости, а продолжительность периода от цветения до созревания сильно варьирует в зависимости от влажности почвы, температуры, вентиляции куста и других [10].

Изменчивость скороспелости в пределах сортов и гибридных популяций есть результат наследственной и ненаследственной изменчивости, что необходимо учитывать в селекционном процессе [7].

\section{Цель исследований}

Изучить наследование хозяйственно-ценных признаков гибридами средневолокнистого хлопчатника, полученых от скрещивания эколого-географически отдалённых сортов.

\section{Материалы и методы}

В ходе проведения экспериментов объектом исследования служило 16 интрогрессивных гибридов средневолокнистого хлопчатника. В качестве стандарта использовали районированный сорт Хисар.

Исследования проводили в опытно-производственном хозяйстве института земледелия ТАСХН, расположенном в Гиссарском районе. Агротехника на селекционных питомниках принята по агрорекомендациям MCX Республики Таджикистан [5].

Опыты закладывали по методике разработанной институтом ВНИИССХ им. Г.С. Зайцева [3]. Математические обработки полученных данных были проведены по Доспехову [4].

\section{Результаты и обсуждение}

Результаты исследования, характеризующие скороспелость гибридных комбинаций и их родительских сортов представлены в таблице 1. Вегетационный период гибридов варьировал от 114 до 122 дней. У всех изученных гибридов вегетационный период был меньше среднего значения двух родителей на 2 - 13 дней (табл. 1).

Наименьшая продолжительность вегетационного периода отмечена у 7 образцов в пределах 114 - 116 дней и наследовалась она промежуточно между родительскими сортами, уклоняясь в сторону отцовских сортов. Скороспелее стандарта Хисор (134 дня) на 18 - 20 дней были все гибриды. Проводили корреляционный анализ между продолжительностью вегетационного периода гибридов с отцовскими сортами: и получили коэффициент корреляции $r=0,610$. Коэффициент наследуемости $\left(h_{2}\right)$ составил 0,62, то есть наследование на $62 \%$ генетически произошло от отцовских сортов.

Наступление бутонизации хлопчатника положительно коррелирует с высотой закладки первого симподия $\left(\mathrm{h}_{2}\right)$. Чем выше закладка первого симподия, тем позже наступает бутонизация.

В наших исследованиях узел закладки первой симподиальной ветви у гибридов составил от 4,4 до 6,2 . В большинстве случаев узел закладки у гибридных комбинаций превышал среднее значение двух родительских сортов. У 5 гибридов доминировала более низкая закладка.

Согласно приведенным данным в таблице 1 величины коэффициента наследуемости $\left(\mathrm{h}_{2}\right)$ признак «узел закладки» наследуется на высоком уровне и находится в зависимости от анализируемой гибридной комбинации в пределах от 0,74, то есть на 74 \% наследуют узел закладки от отцовских сортов. Коэффициент наследуемости узла закладки от материнских сортов незначителен, всего лишь на $12 \%$.

Как известно составляющими такого сложного признака, как «продуктивность растения» является произведение значений признака «масса хлопка-сырца одной коробочки». В производстве востребованы сорта, обладающие не только высокими значениями признаков - скороспелостью, продуктивностью хлопка-сырца одного растения, качеством и количеством волокна, но и высокой массой хлопка-сырца одной коробочки, то есть, чем крупнее и тяжелее коробочка, тем фермеру легче справиться с заготовкой хлопка-сырца. 
Таблица 1. Наследование длины вегетационного периода и высоты закладки первой плодовой ветки внутривидовыми гибридами в селекционном питомнике (данные 2018 г.)

\begin{tabular}{|c|c|c|c|c|c|c|c|c|c|}
\hline \multirow{2}{*}{$\begin{array}{l}\text { № } \\
\Pi / \Pi\end{array}$} & \multirow{2}{*}{ Гибридные комбинации } & \multicolumn{4}{|c|}{$\begin{array}{c}\text { Число дней от всходов до } 50 \text { \% } \\
\text { созревания }\end{array}$} & \multicolumn{4}{|c|}{ Узел закладки, hs } \\
\hline & & гибрид & $\mathbf{P}_{1}$ & $\mathbf{P}_{2}$ & $\begin{array}{c}\text { среднее двух } \\
\text { родителей }\end{array}$ & гибрид & $P_{1}$ & $\mathbf{P}_{2}$ & $\begin{array}{c}\text { среднее двух } \\
\text { родителей }\end{array}$ \\
\hline 1 & АС-4 x Сорбон & 120 & 133 & 126 & 129 & 5,8 & 5,0 & 4,6 & 4,8 \\
\hline 2 & AC-4 × Зироаткор-64 & 116 & 130 & 123 & 126 & 5,6 & 5,0 & 5,2 & 5,5 \\
\hline 3 & ALC-86/6 x Сорбон & 115 & 136 & 128 & 124 & 4,5 & 5,2 & 4,0 & 4,6 \\
\hline 4 & ALC-86/6 x Дехкон & 119 & 128 & 129 & 128 & 5,8 & 5,2 & 4,6 & 4,9 \\
\hline 5 & Cocer-4104 x Сорбон & 114 & 130 & 125 & 128 & 4,4 & 5,6 & 4,5 & 5,0 \\
\hline 6 & Cocer-4104 x Дусти-ИЗ & 116 & 130 & 126 & 128 & 4,0 & 5,7 & 6,6 & 6,1 \\
\hline 7 & CUZ-F ${ }_{3}$ × Зироаткор-64 & 114 & 131 & 123 & 127 & 4,2 & 5,4 & 5,8 & 5,6 \\
\hline 8 & $\mathrm{CUZ}^{3} \mathrm{~F}_{3} \times$ Дехкон & 116 & 132 & 126 & 127 & 4,8 & 5,8 & 5,6 & 5,7 \\
\hline 9 & DAK-66/3 x Сорбон & 116 & 128 & 129 & 128 & 5,6 & 5,6 & 5,2 & 5,4 \\
\hline 10 & DAK-66/3 x Дехкон & 119 & 134 & 124 & 129 & 6,2 & 5,0 & 4,6 & 4,8 \\
\hline 11 & DP-4025 x Сорбон & 119 & 126 & 121 & 123 & 6,2 & 5,6 & 5,4 & 5,5 \\
\hline 12 & DP-4025 x Зироаткор-64 & 122 & 127 & 121 & 124 & 5,0 & 5,8 & 5,2 & 5,1 \\
\hline 13 & DP-5111 x Сорбон & 117 & 137 & 129 & 133 & 5,4 & 4,6 & 5,8 & 5,2 \\
\hline 14 & DP-5111 x Зироаткор-64 & 119 & 132 & 129 & 130 & 5,8 & 5,6 & 5,6 & 5,6 \\
\hline 15 & DPL-4158 x Сорбон & 118 & 141 & 129 & 135 & 5,9 & 5,6 & 6,0 & 5,8 \\
\hline 16 & DPL-4158 x Дехкон & 119 & 137 & 132 & 134 & 5,5 & 4,6 & 5,0 & 4,8 \\
\hline 17 & Хисор (st) & 134 & - & - & - & 6,8 & - & - & - \\
\hline
\end{tabular}

Участвующие в наших исследованиях сорта зарубежной (турецкой) селекции обладают наивысшей средней величиной признака «масса хлопкасырца одной коробочки», как это видной из таблицы 2 и соответственно она равняется средним величинам - 5,0 и 6,4 г. У отечественных сортов от 4,8 до 5,2 г. Средняя величина этого признака у изученных гибридных комбинаций соответственно находится на уровне от 5,8 до 7,2 г. Всё это и определило поведение гибридов в период исследований. Наилучшей средней величиной признака «масса хлопка-сырца одной коробочки» обладали следующие гибридные комбинации: Cocer-4104 х Сорбон (7,2 г), CUZ-F ${ }_{3}$ x Дехкон (7,2 г), AC-4 х Зироаткор-64 (6,8 г), ALC-86/6 x Дехкон (6,8 г), Cocer-4104 х Дусти-ИЗ (6,7 г) и DPL-4158 x Дехкон (6,7 г) (рис. 1).
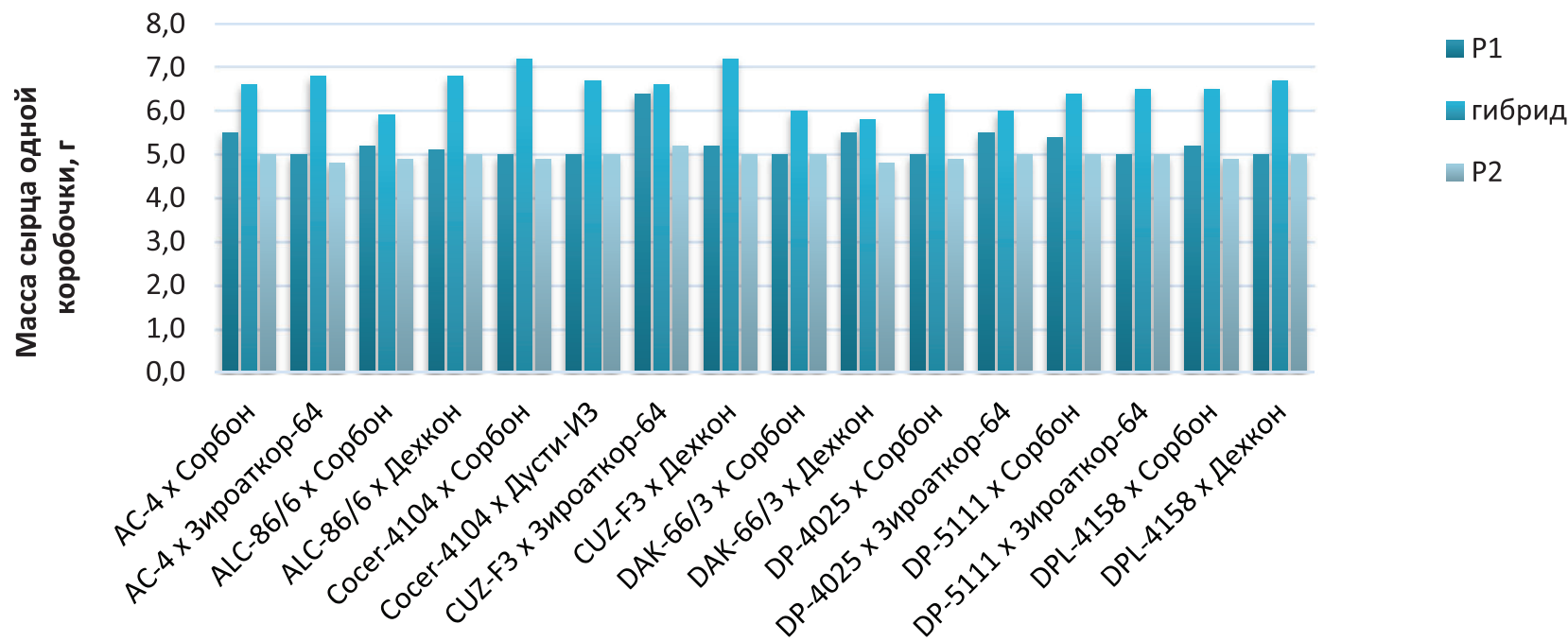

Рисунок 1. Масса хлопка-сырца одной коробочки гибридов и их родительских сортообразцов средневолокнистого хлопчатника в 2018 г. 
Как видно при анализе наследуемости величины признака «масса хлопка-сырца одной коробочки», коэффициент наследуемости $\left(\mathrm{h}_{2}\right)$ находится в диапазоне 86 \% признака, поученного от материнских сортов, а от отцовских сортов - $15 \%$.

Следовательно, у исследуемых гибридов этот признак наследуется в основном от материнских форм и имеется возможность выделять отдельные растения с крупной коробочкой, начиная с первого поколения $\left(\mathrm{F}_{1}\right)$, при этом величина коробочки генетически обусловлена, что очень важно с точки зрения селекционных исследований.

Рассматривая полученные результаты по урожайности хлопка-сырца в расчете на одно растение мож- но отметить, что максимальная величина по популяциям гибридов изменяется в диапазоне - 98,4 - 118,9 г. Из них с самым высоким показателем урожая хлопка-сырца отличались гибриды: Cocer-4104 х Сорбон (118,9 г/растение), ALC-86/6 x Дехкон (116,4 г/растение), DPL-4158 x Дехкон (114,4 г/растение). Самая низкая урожайность наблюдалась у гибридных комбинаций AC-4 x Сорбон (80,8 г/растение), DP-5111 x Сорбон (88,1 г/растение). Полученная урожайность гибридов оказалась на 51,8 - 63,1 г/растение больше, чем среднее значение обоих родительских сортов. Относительно стандартного сорта Хисор (34,8 г/растение) значения признака у гибридов были выше: 46,0 - 84,1 г/растение (табл. 2).

Таблица 2. Наследование массы хлопка-сырца одной коробочки и урожайности внутривидовыми гибридами в селекционном питомнике (данные 2018 г.)

\begin{tabular}{|c|c|c|c|c|c|c|c|c|c|}
\hline \multirow{2}{*}{$\begin{array}{l}\text { № } \\
\mathbf{n} \mathbf{\Pi}\end{array}$} & \multirow{2}{*}{ Гибридные комбинации } & \multicolumn{4}{|c|}{ Крупность коробочек, г } & \multicolumn{4}{|c|}{$\begin{array}{c}\text { Урожай хлопка-сырца, } \\
\text { г/растение }\end{array}$} \\
\hline & & гибрид & $P_{1}$ & $\mathbf{P}_{2}$ & $\begin{array}{c}\text { среднее двух } \\
\text { родителей }\end{array}$ & гибрид & $\mathbf{P}_{1}$ & $\mathbf{P}_{2}$ & $\begin{array}{c}\text { среднее двух } \\
\text { родителей }\end{array}$ \\
\hline 1 & AC-4 x Сорбон & 6,6 & 5,5 & 5,0 & 5,0 & 80,8 & 33,1 & 29,1 & 31,1 \\
\hline 2 & AC-4 × Зироаткор-64 & 6,8 & 5,0 & 4,8 & 4,9 & 110,8 & 45,2 & 37,2 & 41,2 \\
\hline 3 & ALC-86/6 x Сорбон & 5,9 & 5,2 & 4,9 & 5,0 & 98,4 & 54,3 & 34,3 & 44,3 \\
\hline 4 & ALC-86/6 x Дехкон & 6,8 & 5,1 & 5,0 & 5,0 & 116,4 & 60,0 & 40,0 & 50,0 \\
\hline 5 & Cocer-4104 x Сорбон & 7,2 & 5,0 & 4,9 & 4,9 & 118,9 & 46,0 & 36,0 & 41,0 \\
\hline 6 & Cocer-4104 x Дусти-ИЗ & 6,7 & 5,0 & 5,0 & 5,0 & 110,1 & 67,4 & 37,4 & 52,4 \\
\hline 7 & CUZ-F $\mathrm{F}_{3}$ × Зироаткор-64 & 6,6 & 6,4 & 5,2 & 6,2 & 90,0 & 60,2 & 30,2 & 45,2 \\
\hline 8 & $\mathrm{CUZ}_{-\mathrm{F}_{3}}^{3} \times$ Дехкон & 7,2 & 5,2 & 5,0 & 5,1 & 111,1 & 57,2 & 47,2 & 52,2 \\
\hline 9 & DAK-66/3 x Сорбон & 6,0 & 5,0 & 5,0 & 5,0 & 109,4 & 49,1 & 30,1 & 39,6 \\
\hline 10 & DAK-66/3 x Дехкон & 5,8 & 5,5 & 4,8 & 4,8 & 111,3 & 30,0 & 28,0 & 29,0 \\
\hline 11 & DP-4025 x Сорбон & 6,4 & 5,0 & 4,9 & 4,9 & 110,5 & 42,2 & 30,2 & 36,2 \\
\hline 12 & DP-4025 x Зироаткор-64 & 6,0 & 5,5 & 5,0 & 5,0 & 90,5 & 59,0 & 36,0 & 47,5 \\
\hline 13 & DP-5111 x Сорбон & 6,4 & 5,4 & 5,0 & 5,2 & 88,1 & 36,2 & 29,2 & 32,7 \\
\hline 14 & DP-5111 x Зироаткор-64 & 6,5 & 5,0 & 5,0 & 5,0 & 94,9 & 51,1 & 37,1 & 44,1 \\
\hline 15 & DPL-4158 x Сорбон & 6,5 & 5,2 & 4,9 & 5,0 & 99,5 & 69,3 & 42,3 & 55,8 \\
\hline 16 & DPL-4158 x Дехкон & 6,7 & 5,0 & 5,0 & 5,0 & 114,4 & 33,0 & 27,0 & 30,0 \\
\hline 17 & Хисор (st) & 5,0 & - & - & - & 34,8 & - & - & - \\
\hline
\end{tabular}

Анализируя величину коэффициента наследуемости $\left(\mathrm{h}_{2}\right)$ у внутривидовых гибридов следует сказать, что признак «урожай хлопка-сырца» наследуется промежуточно по изученным гибридным комбинациям на высшем уровне, а его величина находится в пределах от 0,85 или $85 \%$.

Судя по величинам исследуемых признаков и их наследования по потомствам смело можно сказать о возможности целенаправленного подбора родительских пар для скрещивания.

\section{Выводы}

При рассмотрении результатов исследований среди созданных гибридных комбинаций к наилучшим с селекционной точки зрения по средней величине основных изученных признаков (скороспелости, массы хлопка-сырца одной коробочки и урожайно- сти) следует отнести гибриды: АС-4 x 3ироаткор-64, Cocer-4104 x Сорбон, Cocer-4104 х Дусти-ИЗ и CUZ-F ${ }_{3}$ х Дехкон. Гибриды целесообразно использовать в селекционном процессе при создании новых перспективных сортов.

Следовательно, все гибриды обладали коротким вегетационным периодом. Наследование скороспелости (длины вегетационного периода) внутривидовыми гибридами происходит в равной степени от отцовских местных сортов на $62 \%$.

К наиболее крупнокоробочным исходным источникам (донорам) из созданных географически отдаленных гибридов в рамках исследований следует отнести комбинации Cocer-4104 x Сорбон (7,2 г), CUZ-F ${ }_{3}$ × Дехкон (7,2 г), AC-4 x Зироаткор-64 (6,8 г), ALC-86/6 x Дехкон (6,8 г), величина коэффициента 
наследуемости $\left(\mathrm{h}_{2}\right)$ этого признака находится в диапазоне $86 \%$.
Анализ урожая хлопка-сырца показал сверхдоминантность гибридных популяции, коэффициент наследуемости $\left(\mathrm{h}_{2}\right)$ находился в пределах $85 \%$.

\section{ЛИТЕРАТУРА}

1. Вавилов, Н.И. Закон гомологических рядов в наследственной изменчивости / Н.И. Вавилов // Теоретические основы селекции растений. - Т. 1. Общая селекция растений. - М.: Сельхозгиз, 1935. - С. 75 - 128.

2. Доспехов, Б.А. Методика полевого опыта (с основами статистической обработки результатов исследований / Б.А. Доспехов. - М.: Книга по Требованию, 2012. - 352 с.

3. Зайцев, Г.С. Методические указания селекцентра по хлопчатнику / Г.С. Зайцев. - Ташкент. - 1980. - С. 24.

4. Махмуджанов, А.М. О наследуемости и корреляции признака у гибридов хлопчатника / А.М. Махмуджанов // В сб. «Научные основы получения высоких урожаев с/х культур. - Душанбе. - 1980. - С. 35 - 37.

5. Научно обоснованная система ведения сельского хозяйства Таджикистана (на тадж. яз.) / под ред. Х.М. Ахмадов, Т.Н., Набиев, Т.А. Бухориев. - Душанбе: Матбуот, 2009. - С. 764.

6. Симонгулян, Н.Г. Генетика, селекция и семеноводство хлопчатника / Н.Г. Симонгулян, С.Р. Мухамеджанов, А.Н. Шафрин. - Ташкент: Мехнат, 1987. - С. 318.

7. Симонгулян, Н.Г. Комбинационная способность и наследуемость признаков хлопчатника / Н.Г. Симонгулян. Ташкент: ФАН, 1977. - С. 98.

8. Суярова, С.Дж. Создание интрогрессивных, скороспелых, высокопродуктивных генотипов в селекции хлопчатника на основе использования географически отдалённых форм: дис. ... канд. с.-х. наук / С.Дж. Суярова. - Душанбе. - 2012. - С. 114.

9. Устименко-Бакумовский, Г.В. Растениеводство тропиков и субтропиков / Учебник М.: Колос, 1980. - 327 с.

10. Фан, Т.К. Наследование и корреляция хозяйственно-ценных признаков хлопчатника при внутривидовой и межвидовой гибридизации: дис. ... канд. с.-х. наук / Т.К. Фан. - Ташкент. - 1990. - 200 с.

\section{REFERENCES}

1. Vavilov, N.I. The law of homological rows in hereditary variability / N.I. Vavilov // theoretical foundations of plant breeding. - Vol. 1. General plant breeding. - M.: Selkhozgiz, 1935. - P. $75-128$.

2. Dospekhov, B.A. Methodology of field experience (with the basics of statistical processing of research results / B.A. Dospekhov. - M.: book on demand, 2012. - 352 p.

3. Zaitsev, G.S. Methodical instructions of the cotton growing center / G.S. Zaitsev. Tashkent. - 1980. - P. 24.

4. Mahmadjonov, A.M. On the heritability and correlations of this trait in the hybrids of cotton / A.M. Mahmadjonov // VSB. "Scientific basis for obtaining high yields of agricultural crops. - Dushanbe. - 1980. - P. 35 - 37.

5. Science-based system of agriculture in Tajikistan (in Taj. Lan.) / Kh.M. Akhmadov, T.N. Nabiev, T.A. Bukhoriev. - Dushanbe: Matbuot. - 2009. - P. 764.

6. Simangus N.G. genetics, selection and seed production of cotton / N.G. Simangus, S.R. Mukhamedzhanov, A.N. Safrin.- Tashkent: Mehnat, 1987. - P. 318.

7. Simangus, N.G. combining ability and heritability of cotton characteristics / N.G. Simangus. Tashkent: FAN, 1977. P. 98.

8. Suyarova, S.Ya. creation of introgressive, precocious, highly productive genotypes in cotton growing based on the use of geographically remote forms: Dis. ... candidate of agricultural Sciences / S. Ya. Suyarova. Dushanbe.- $2012 .-$ P. 114.

9. Ustimenko-Bakumovsky G.V. Crop production of tropics and subtropics / Textbook M.: Kolos, 1980. - 327 p.

10. Fan, T.K. inheritance and the ratio of economically valuable traits of cotton in intraspecific and interspecific hybridization: Dis. ... Cand. agricultural Sciences / T.K. Fan.- Tashkent. - 1990. - 200 P.

\section{Садиков Аслиддин Тожидинович}

Старший научный сотрудник отдела

«Селекция и технологии средневолокнистого

хлопчатника»

E-mail: dat.tj@mail.ru

Институт земледелия ТАСХH

Адрес: г. Гиссар, Республика Таджикистан,

\section{Asliddin T. Sadikov}

Senior researcher of the department

«Selection and technology of medium-fibrous

cotton»

E-mail: dat.tj@mail.ru

Institute of Farming TAAS

Address: Hissar city, Republic of Tajikistan 


\section{СДЕЛАННОЕ ОСТАНЕТСЯ ПОТОМКАМ (к 80-летию Г.Д. Лось)}

У Галины Даниловны Лось 12 декабря 2020 г. юбилей - 80 лет со дня рождения. О таких ученых, как Галина Даниловна, писать легко и очень сложно. Можно вспомнить ее основные жизненные вехи, отметить научные достижения (а их предостаточно, одних авторских свидетельств на созданные сорта более 50) и получим обычный портрет ученого. А хочется показать лучшие человеческие качества Галины Даниловны: научную честность, принципиальность, обостренное чувство справедливости, душевную доброту, материнскую заботу не только о детях, внуках, но и о младших коллегах по работе. Как все это описать в коротком очерке?

Моя задача облегчается тем, что в 2017 г. Эльмира Рубеновна Авакян поместила в журнале «Рисоводство» в рубрике «Имя в науке» статью о Лось Галине Даниловне «Главное в науке - вдохновение». Это дает мне возможность не останавливаться на биографических данных нашего юбиляра, а показать ее вклад в рисовую селекционную науку и осветить некоторые черты характера Галины Даниловны, которые помогли ей выполнить такие исследования, результатами которых будут пользоваться еще многие поколения ученых-рисоводов.

Галина Даниловна Лось принята на работу в отдел селекции Всесоюзного НИИ риса 29 мая 1974 г. будучи уже кандидатом сельскохозяйственных наук. Несмотря на это ученое звание, ей предложили только должность младшего научного сотрудника в лаборатории исходного материала. Столь высокие требования предъявлялись к научному персоналу, набираемому в институт. В лаборатории исходного материала одним из направлений были исследования по гибридизации риса и ей предложили осваивать эту непростую работу.

В этот период при ВНИИ риса был создан Всесоюзный селекционный центр. Специалисты Центра должны были не только создавать сорта риса в головном учреждении, но и обеспечивать селекционным материалом рисовые опытные станции Ростовской области и Дальнего Востока, а также Украины, Казахстана и Узбекистана, где велась селекция риса. В гибридизационном центре ВНИИ риса выполнялись заявки на получение гибридов от всех селекционеров, работающих с рисом в стране. Поэтому успех селекции риса в СССР во многом определялся работой гибридизаторов.

Следует отметить, что рис является сложной культурой для проведения гибридизации. Он имеет мелкие колоски. В цветке 6 тычинок (в два раза больше чем у пшеницы), которые расположены очень близко к рыльцу пестика. При температуре воздуха свыше $20^{\circ} \mathrm{C}$ малейшее повреждение пыльника приводит к самоопылению цветка.

Как известно, гибридизация риса складывается из двух этапов: кастрации цветков на материнской форме и опыления пыльцой отцовских форм. Гибридизация, как метод создания нового исходного материала, внедрена в практику российской селекции риса еще в конце 30-х годов XX века. Долгое время при кастрации обрезали верхушку цветка и удаляли пыльники пинцетом, иглой или выдавливанием. Этот метод прост, но мало эффективен. Поэтому специалисты вели постоянный поиск более эффективных способов кастрации. Такие исследования на Кубани проводили А. П. Сметанин, С. Б. Мосина, Р. В. Третьяков, Т. Г. Мазур, В. Н. Шиловский, В. К. Сорокин. Для кастрации риса использовали горячую воду, пар, токи высокой частоты и различные химические вещества.

Получив задание заниматься гибридизацией, Галина Даниловна со всей тщательностью изучила и перепроверила все ранее применяемые приемы кастрации и пришла к выводу, что эти приемы трудоемки, требуют специальной аппаратуры и приспособлений. Поэтому их сложно применять для массовой гибридизации.

Можно понять душевные терзания начинающего исследователя, когда она должна была доложить свои выводы своим старшим коллегам на заседании отдела селекции, которым руководил А. П. Сметанин. Он прошел Великую отечественную войну, был директором Кубанской рисовой станции, имел весьма жесткий характер, и сотрудники отдела его, откровенно говоря, побаивались. Однако выслушав обстоятельный доклад, А. П. Сметанин только спросил:

- Что вы, Галина Даниловна, предлагаете взамен этих методов. Критиковать просто, какие ваши предложения?

Ответ у Галины Даниловны был готов:

- Еще в 1933 году Ван-дер Мюллен, работающий на острове Ява, предложил метод обрезания цветковых чешуй с последующим удалением пыльников с помощью вакуума. Я попробовала для этого использовать пылесос, но он не годится. В качестве насоса можно использовать специальный медицинский компрессор.

После этого заседания А. П. Сметанин добился приобретения нужного оборудования. Гибридизаторы перешли на вакуумную кастрацию цветков риса. 
До начала 80-х гг. XX века все селекционные опыты размещались в поселке Рисоопытный Красноармейского района, где ранее была Кубанская РОС, а потом элитно-семеноводческое хозяйство «Красное». Ежедневно сотрудники института риса ездили вахтовым автобусом на свои опытные поля.

Там же была и вегетационная площадка, на которой в сосудах выращивали растения родительских форм для гибридизации. Рис начинал выметывать во второй половине июля, когда с восходом солнца воздух очень быстро нагревался. Учитывая это, гибридизаторы начинали кастрацию рано утром с 5 часов и работали до 7, максимум до 8 часов. А после полудня проводили опыление. В период массовой гибридизации Галине Даниловне приходилось оставаться ночевать в поселке Рисоопытном, чтобы успевать явиться на площадку к 5 утра.

Обрезанные чешуйки цветков на воздухе быстро подсыхали, что приводило к резкому снижению завязываемости гибридных зерновок, даже при оптимальном опылении. В результате завязываемость зерновок была низкая - 8-10 \%, и лишь в лучших вариантах получалось до 15 \%. Для получения необходимого объема гибридных семян, гибридизаторы вынуждены были обрабатывать по каждой комбинации несколько сотен цветков. Задача повышения эффективности гибридизации риса стояла очень остро.

После изучения работ отечественных и зарубежных гибридизаторов Г. Д. Лось убедилась, что на завязываемость зерновок риса сильно влияет влажность воздуха после кастрации цветков и в период опыления. По её предложению были построены пленочные теплицы, в которые помещали сосуды с материнскими формами после кастрации на две недели. В теплицах устанавливали приборы гигрографы, которые фиксировали влажность воздуха.

В октябре 1975 г. Лось Г. Д. переводят на должность старшего научного сотрудника и поручают руководство гибридизационным центром. Продолжая совершенствовать элементы гибридизации, удалось повысить процент удачи до 20-25. Но и этого было мало.

Узким местом было завязывание зерен у риса после опыления. Успех опыления зависит от жизнеспособности пыльцы, а также от того, повреждены или нет рыльца пестика при кастрации. На Кубани применяли разные варианты принудительного способа опыления риса: внесение пинцетом в кастрированный цветок целых или раздавленных пыльников, нанесение предварительно собранной пыльцы кисточкой, подстановка срезанных отцовских метелок в один изолятор с кастрированными материнскими, использование опылителя «Шмель». Оказалось, что предварительный сбор пыльцы резко снижает результативность опыления. Наилучший показатель завязываемости (19,8 \%) получила Т. Г. Мазур при ограниченно свободном опылении. Однако этого было недостаточно для существенного повышения эффективности селекционной работы.

Проверив на практике все ранее используемые варианты, Галина Даниловна пришла к заключению, что завязываемость гибридных зерновок зависит от следующих факторов: повышенной чувствительности цветков к травмированию, воздействия на генеративные органы ветра, солнечных лучей, повышенной температуры, пониженной влажности воздуха, от качества пыльцы, морфологических особенностей цветков растений разных сортов, а также от квалификации исполнителя.

Оказалось, что у двух техников-гибридизаторов, работающих рядом, при точном выполнении всех приемов гибридизации завязываемость зерновок получается разной. По образному выражению Галины Даниловны: «гибридизатор должен быть с «легкой» рукой, как художник, музыкант или другой творческий работник».

Таким даром, «легкой рукой», обладали ее помощники - Кудряшова Галина Семеновна, в период работы в ЭСХ «Красное»; Киреева Анастасия Дмитриевна, после переноса гибридизации во ВНИИ риса, а потом и сестры Новиковы - Вера и Надежда (ныне Степанова В. С. и Шкарбан Н. С.). Все они помогли осуществить теоретические задумки Г. Д. Лось по совершенствованию технологии гибридизации риса.

С 1979 г. в практику гибридизации риса для опыления был внедрен твел-метод. При этом перед опылением отрезают верхушку изолятора, одетого на кастрированную метелку, вводят цветущую метелку отцовской формы и энергично вращают. Облачко пыльцы оседает на открытые цветки. Этот естественный способ попадания пыльцы на рыльце пестика приводил к наилучшему завязыванию зерновок.

К 1986 г. во ВНИИ риса завершили запуск фитотрона. В его комплекс входили 24 камеры искусственного климата (КИК), на двух стеллажах которых помещалось 64 вегетационных сосуда, две теплицы объемом по 2400 сосудов и два сетчатых домика такого же объема. Селекционеры получили возможность работать круглогодично.

КИК в первую очередь предоставили гибридизаторам и биотехнологам. Камеры позволяли регулировать длину светового дня и температуру в течение суток. Учитывая, что рис культура короткого дня, в камерах для гибридизации установили 12-часовой фотопериод, освещенность свыше 30 тыс. люксов и температуру днем 26-28 ${ }^{\circ} \mathrm{C}$ и ночью - 22-24 ㄷ. При таких условиях растения риса росли и развивались очень быстро. В период выметывания температуру в КИК с 6 до 10 утра понижали до 20 C, чтобы притормозить развитие цветков. Гибридизаторы приходили на работу к 8 часам и начинали кастрацию материнских форм. Для проведения кастрации выделили специальную комнату, где разместили все оборудование и тем- 
пературу поддерживали на уровне 20-21 ㄷ. Гибридизаторы спокойно в течение двух часов выполняли запланированную кастрацию и возвращали сосуды с материнским формами в КИК. Там с 10 часов утра переключали температурный режим и к 13 часам начиналось цветение. В течение 2-2,5 часов проводили опыление твел-методом и в 16 часов гибридизаторы заканчивали свой рабочий день.

Посев в камерах проводили так, что первый цикл скрещиваний приходился на декабрь, а второй на апрель. Летом оставалось только вырастить гибриды F1. В этих условиях специалисты гибридизационного центра могли спокойно по очереди отправляться в отпуск в летнее время.

При первом же посеве сортов в КИК обнаружилась проблема, с которой раньше не сталкивались. Сорта риса по-разному реагировали на 12-часовой фотопериод. Для выяснения этого вопроса мы с Галиной Даниловной провели серию опытов. Один и тот же набор сортов выращивали на вегетационной площадке при естественных условиях и в КИК. Результаты были для нас совершенно новыми. Например, два сорта: ВНИИР 8847 и Кулон на площадке выметывали одновременно через 77 дней, а в камере наблюдалась другая картина: у ВНИИР 8847 метелки появлялись через 52 дня, как у скороспелого сорта Союзный 244, а у Кулона - через 77 дней. Следовательно, без совмещения сроков цветения скрестить в КИК эти два сорта невозможно. Неожиданной была реакция и у среднеспелого сорта Прикубанский. На площадке он созревал за 115 дней. При этом растения его были высотой около 90 см. В КИК сорт Прикубанский вырастал до 1,5 м и созревал за 130 дней. Из этого следовал вывод: будущие родительские формы необходимо предварительно изучать в условиях КИК, чтобы облегчить работу по гибридизации.

В итоге использование вакуумной кастрации медицинским компрессором и опыления твел-методом позволило увеличить завязываемость гибридных зерновок до 50-60 \%, а по отдельным комбинациям до 90 \%. При этом выход гибридов первого поколения превышал 90 \%. И в этом достижении главную заслугу необходимо отдать разработчику современной технологии гибридизации Галине Даниловне Лось.

Мне, как заведующему лаборатории исходного материала, часто приходилось сопровождать отечественные и иностранные делегации, показывать опыты, проводимые сотрудниками лаборатории. Так, в конце 1986 г. во ВНИИ риса прибыла большая делегация из Китая. В составе ее были различные специалисты, включая селекционеров. В фитотронном комплексе Галина Даниловна должна была продемонстрировать результаты гибридизации в камерах искусственного климата. Она коротко рассказала методику проводимой гибридизации и сообщила, что по некоторым комбинациям процент завязывания гибридных зерновок достигает 85-90. Руководитель китайской делегации, селекционер, не удержался и возразил, что это нереально. Когда переводчик сообщила сказанное китайским ученым, Галина Даниловна пригласила его зайти в КИК и сняла изоляторы с двух метелок. На одной метелке было 29 зерновок в 30 кастрированных цветках, а в другой - 28. Почетный гость долго смотрел на эти метелки, подсчитывал зерновки и воскликнул:

- Gold hands, Gold hands!! (Золотые руки!!).

Затем повернулся к смущенной Галине Даниловне и поцеловал ей руку.

Руководитель китайской делегации обратился к директору института и сказал, что если в России работают такие специалисты, то мы готовы на любые совместные исследования. Директор был очень доволен такой высокой оценкой. Это было, по его словам, мировое признание уровня работ ВНИИ риса.

Провести гибридизацию и получить гибридные зерновки - это только часть дела. Из них необходимо вырастить растения F1 и проверить их гибридность. Здесь тоже имеется ряд нюансов, которые надо учитывать, чтобы получить максимальный выход гибридов. Среди них период покоя свежеубранных семян. Сразу поле уборки они не прорастали. Галине Даниловне удалось разработать эффективный метод стимулирования прорастания гибридных зерновок, который позволял практически избежать потерь полученных семян.

О каждом разработанном и внедренном в практику новом приеме Г. Д. Лось сообщала в своих публикациях. Полное изложение всей гибридизационной технологии с описанием многих тонкостей, которые надо учитывать для получения максимального эффекта, Галина Даниловна приводит в своей статье «Методика гибридизации риса», опубликованной в журнале «Рисоводство» № 10, 2007 г. Изложенный в этой статье материал, является настоящим учебным пособием для специалистов, работающих с рисом в настоящем и будущем времени.

В 2007 г. Галина Даниловна Лось приняла очень трудное для себя решение - оставить работу, чтобы больше внимания уделять семье. При всей преданности научной работе, Галина Даниловна оставалась любящей мамой и бабушкой. Ее две дочери Зина и Оля, после окончания экономического факультета Кубанского ГАУ, работают преподавателями. Обе защитили кандидатские диссертации. Сейчас Зинаида Ивановна Кругляк и Ольга Ивановна Швырева - профессора учетно-финансового факультета. Внук Галины Даниловны, Виктор, обучается в магистратуре. А внучка Анастасия - учащаяся колледжа. Они частые гости у бабушки. Скучать ей не дают.

Галина Даниловна со спокойной душой смогла оставить свою работу. Она передала дело в надежные руки своих учеников. Гибридизационной центр возглавила кандидат сельскохозяйственных наук Ирина 
Николаевна Чухирь. Она несколько лет помогала в работе Галине Даниловне, вникала в тонкости гибридизационной технологии и выращивания гибридов. В ее команде прекрасные специалисты Степанова В. С. и Шкарбан Н. С., которые не только сами проводят гибридизацию, но и обучают этому тонкому делу молодых помощников.

И сейчас можно с уверенностью сказать, что коллектив гибридизаторов ФНЦ риса успешно справляется с поставленной задачей. Они полностью освоили всю технологию, разработанную Галиной Даниловной, и периодически вносят рациональные предложения по улучшению отдельных ее элементов. Это лучший их подарок к юбилею своего наставника.

В заключение хочется высказать Галине Даниловне огромную благодарность за всю ее плодотворную работу, результаты которой явились прочным фундаментом в селекции риса в России на многие годы и пожелать ей крепкого здоровья в это непростое время.

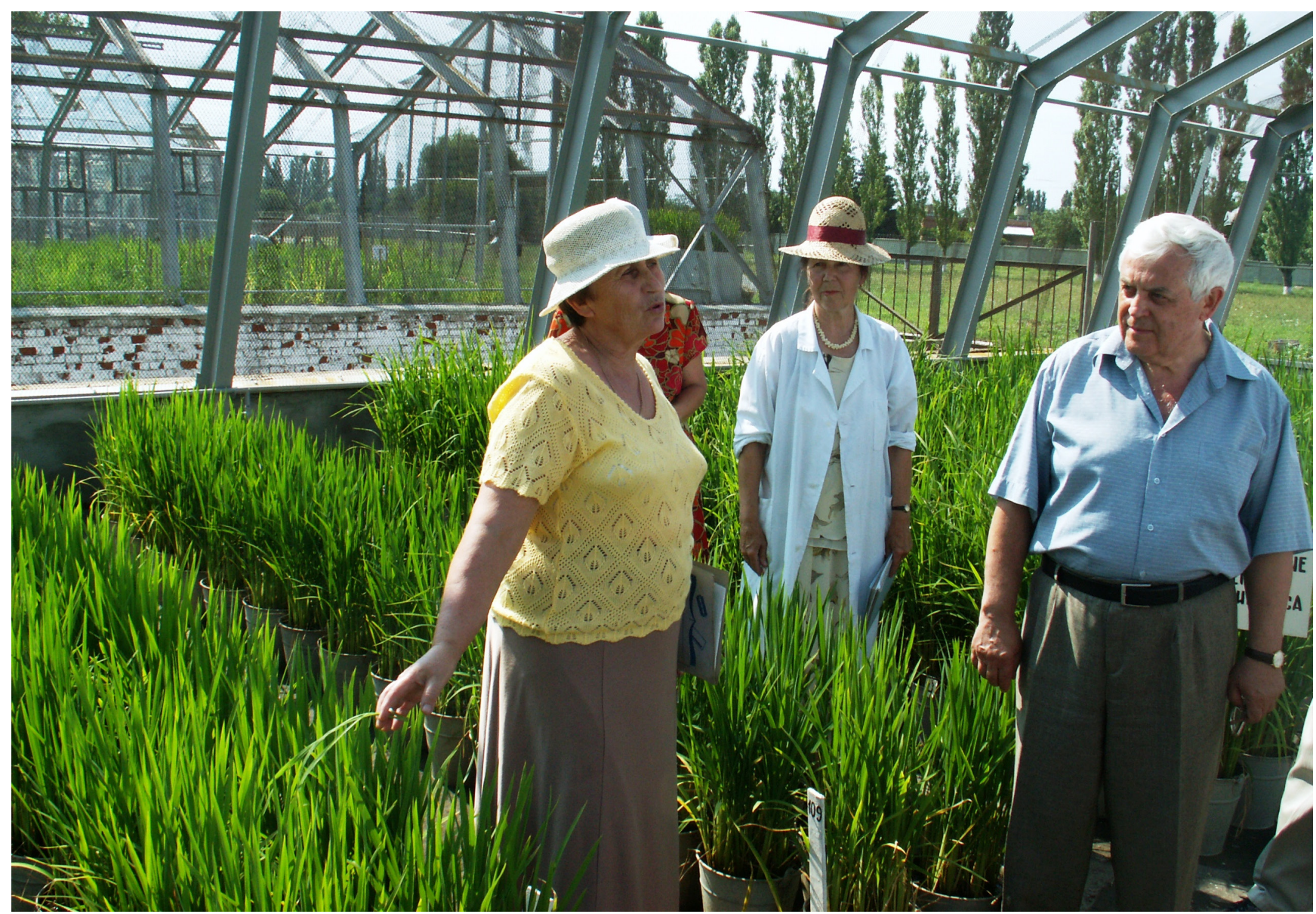

Ведущий научный сотрудник Г. Д. Лось докладывает методической комиссии ВНИИ риса результаты своих исследований, 2006 г.

Главный научный сотрудник отдела селекции ФГБНУ «Федеральный научный центр риса», доктор сельскохозяйственных наук, профессор Г. Л. Зеленский 


\section{РИСОВОДСТВО / RICE GROWING}

НАУЧНО-ПРОИЗВОДСТВЕННЫЙ ЖУРНАЛ

SCIENTIFIC RESEARCH AND PRODUCTION MAGAZINE

ISSN $1684-2464$

4 (49) 2020

Подписано в печать

00.09 .2020

Формат 64x90/8

Бумага офсетная

Усл. печатных листов 8,27

Заказ № 41/00000. Тираж 500 экз. 